\title{
MAPAS DE SOLOS PRODUZIDOS EM ESCALAS E ÉPOCAS DISTINTAS
}

\author{
Enio Fraga da Sula \\ Engenheiro Agrônomo
}

Orientador: Prof. Dr. GERD SPAROVEK

Tese apresentada à Escola Superior de Agricultura "Luiz de Queiroz", Universidade de São Paulo, para obtenção do título de Doutor em Agronomia, Área de Concentração: Solos e Nutrição de Plantas.

P I R A C I C A B A

Estado de São Paulo - Brasil

Março - 2000 


\section{ERRATA}

Enio Fraga da Silva. Mapas de solos produzidos em escalas e épocas distintas.

p. item linha

i rosto última

$32 \quad 3.1 .3$ vigésima

$32 \quad 3.1 .3$ vigésima primeira

$32 \quad 3.1 .3$ vigésima segunda

$34 \quad 3.1 .3$ quinta

$34 \quad 3.1 .3$ sexta

$34 \quad 3.1 .3$ sétima

$34 \quad 3.1 .3$ oitava

$34 \quad 3.1 .3$ nona

$34 \quad 3.1 .3$ décima

$34 \quad 3.1 .3$ décima primeira onde se lê leia-se

Março - $2000 \quad$ Abril - 2000

... a $15 \%$, representando $70 \%$... a $20 \%$, representando $64,1 \%$

... 2 a $5 \%$ com $13 \%$...

... 2 a $5 \%$ com $10,6 \%$...

... menos de $5 \%$ da ...

... menos de $4 \%$ da ...

$0-2 ; 83,72 ; 4,2$;

$0-2 ; 74,6 ; 3,7$;

$2-5 ; 253,24 ; 12,7$;

$2-5 ; 210,4 ; 10,6$;

$5-10 ; 772,44 ; 38,8$;

$5-10 ; 482,12 ; 24,2$;

$10-20 ; 839,20 ; 42,6$;

$10-20 ; 794,68 ; 39,9$;

$>20 ; 41,80 ; 2,1$;

$>20 ; 381,36 ; 19,2$;

Urbano; 39,2; 2,0;

Represa; 8,04; 0,4; 


\title{
Dados internacionais de Catalogação na Publicação (CIP) DIVISÃO DE BIBLIOTECA E DOCUMENTAÇĀO - Campus "Luiz de QueirOz"/USP
}

\author{
Silva, Enio Fraga da \\ Mapas de solos produzidos em escalas e épocas distintas / Enio Fraga da Silva. - - \\ Piracicaba, 2000. \\ 177 p. : il. \\ Tese (doutorado) - Escola Superior de Agricultura Luiz de Queiroz, 2000. \\ Bibliografia. \\ 1. Classificação do solo 2. Levantamento do solo 3. Mapa pedológico 4. Microbacia do \\ Córrego do Ceveiro I. Título
}

CDD 631.47

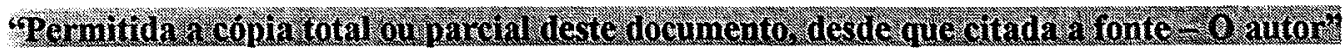


"Há Homens que lutam por um dia, esses são bons.

Há outros que lutam por um ano, esses são muito bons.

Há aqueles que lutam por toda a vida, esses são imprescindíveis." Bertolt Brecht

Aos meus pais Tonton (saudades) e Ena, que me deram tudo na vida: Amor e Educação;

À Dôdinha minha anjinha;

À Cris minha amada irmã;

À Marquinhos meu irmão sarado; Aos meus avós e a minha Vovózinha Didi querida; Aos meus filhos Matheus, Ticiane, Ricardinho, Felipe, Tatiana e Bruno; Aos meus "novos" pais e irmãos, Silva e Conceição, Zelda e Celso; À Geo, Fernando e Dolôres meus padrinhos queridos; Aos meus tios, primos e amigos. Com amor, OFEREÇO.

À Elizabete, meu amor, mulher guerreira, amiga e companheira. 


\section{AGRADECIMENTOS}

Ao Povo Brasileiro, 500 anos de miséria, sem educação, sem saúde, sem teto e sem terra, sem salário, sem imunidade e sem precatórios, que com sacrifício paga pela educação de uns poucos;

À Embrapa Solos, através de seus chefes: Drs. Doracy P. Ramos (quem me ensinou a arte da pedologia), Celso Manzatto, Paulo Eira, Antonio Ramalho, Humberto Santos e Sergio Fagundes, por tornar possivel esse treinamento;

À Escola Superior de Agricultura "Luiz de Queiroz", em especial ao Curso de Pós-Graduação e ao Departamento de Solos e Nutrição de Plantas, através do Prof. Dr. Arary Marconi, pelo curso oferecido e apoio no desenvolvimento do trabalho;

Ao Conselho Nacional de Pesquisa, pela concessão da bolsa de estudos;

À Fundação de Amparo à Pesquisa do Estado de São Paulo, pelo financiamento do projeto de pesquisa;

Aos Drs. Francesco Palmieri e Ricardo Marques Coelho, pela amizade, sugestões e valiosa contribuição dada ao trabalho.

Aos Professores Drs. Miguel Cooper pela amizade e participação no summary; José Demattê, Vitti e Paulo Libardi pelo apoio e exemplo de professores; Pablo Torrado, Luis Alleoni e Sebastião Lima Filho pelas sugestões;

Ao Prof. Dr. Gerd Sparovek, pela orientação.

À Linda Monica Premazzi pela amizade e dedicação na elaboração da tese.

À José Ronaldo de Macedo, Peterson Fiorio, Daniele Focht, Luciano Mattos, Udson Roberto, Simone Ranieri, Élcio do Nascimento, Luciana Castro, Marcos Nanni, Silvânia Machado, Rodrigo Maule, Cristina Simonetti e Alvaro Mafra, pela amizade, carinho e auxílio nas várias fases do trabalho. 
À Portugal, Célia, Fafá, Fernando Amaral e Josélia por cuidarem de mim.

À Penha e Ione pela ajuda nas referências bibliográficas.

Aos amigos, Alexandre, Alvito, Arilene, Capeche, Carla, Claudia, Daniel, Denize, Fernando, Gustavo, Helga, Ingo, Ivan, Janie, Luty, Maggie, Mariza, Marcia, Marcos, Miriam, Raquel, Ronaldo, Silvio, Tony, Zé Ricardo e Zé Roberto, apesar de distantes estão sempre presentes.

Aos funcionários e professores do Dep. de Solos e Nutrição de Plantas, em especial à Flavia, Beth, Célia, Clotilde, Marta, Marcia, Cristina, Martinha, Jacke, Elizangela, Ney, Nelson, Jair, Dorival, Wladimir, Luciano, Sergio, Lico, Anderson e Dú, pelo convívio e auxílio.

Aos funcionários e pesquisadores da Embrapa Solos.

Aos professores e amigos do Dep. Solos da UFRRJ, que me deram a base do conhecimento de solos.

Ao Penca, Luiz, João, Wilson, Ari e Odair pelo apoio esportivo.

Ao Claudio e Paula pelas cópias e encadernação da tese.

A minha familia, Geo e Bete, Nely, Vera e Alício, Lurdes, Lia, Dith e Braulio, Zé, Fraga, Tereza, Itamar, Jorge, Lúcia, Gervásio, Luciano, Norma, Van, Aninha, Liliu, Gabi, Nana, Pablo, Paloma, Marcelo, Rogério, Tharso, Gisa, Diva, Silvio e Claudio e os mais novos, pelo apoio, carinho e amor.

Às duas famílias e a Dra. Helen, que num gesto de amor permitiram que eu continuasse vendo as pessoas que amo.

A todos aqueles que direta ou indiretamente contribuíram para a realização deste trabalho.

A Deus pela minha vida, minhas conquistas e por ter colocado cada pessoa aqui citada ou não, em meu caminho... 


\section{SUMÁRIO}

página

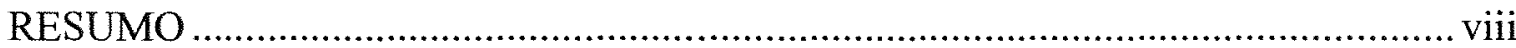

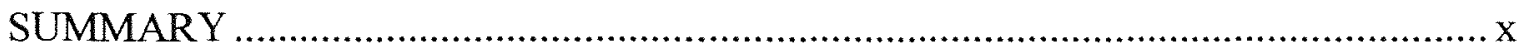

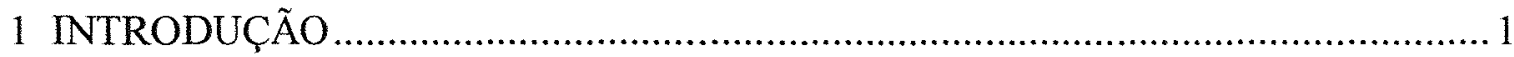

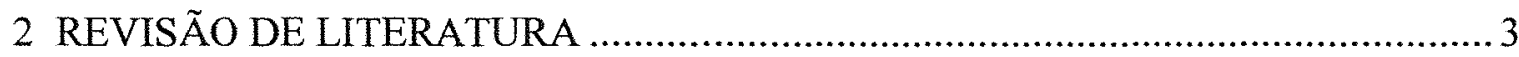

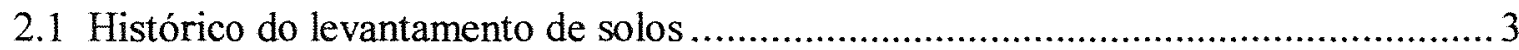

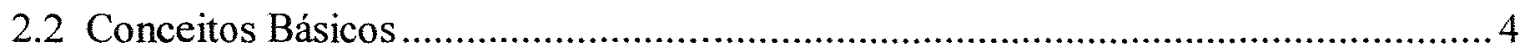

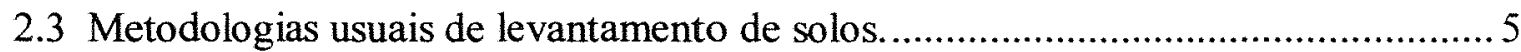

2.3.1 Métodos de Prospeç̧ão (Embrapa, 1995) ……................................................. 6

2.3.2 Densidade de Observações ........................................................................... 7

2.3.3 Escala do Material Básico ................................................................................. 8

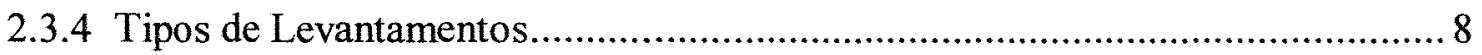

2.4 Métodos modernos de levantamento de solos ................................................. 10

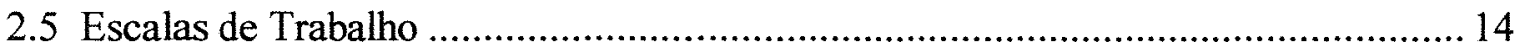

2.6 Medidas de qualidade dos mapas de solos .......................................................... 16

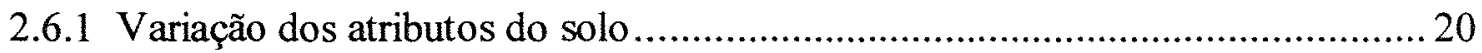

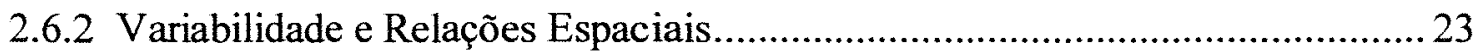

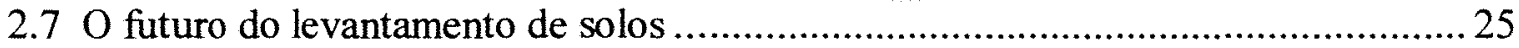

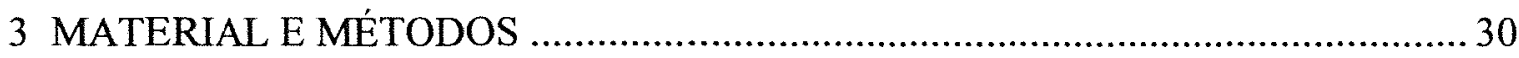

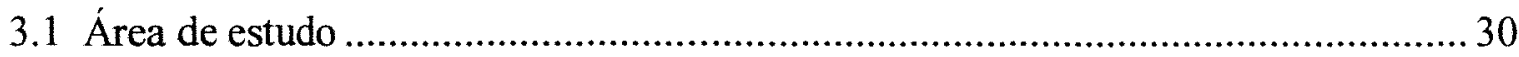

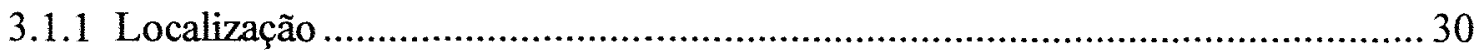

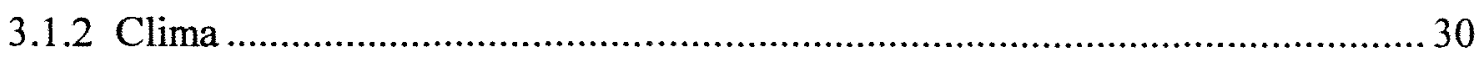

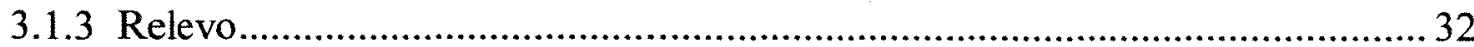

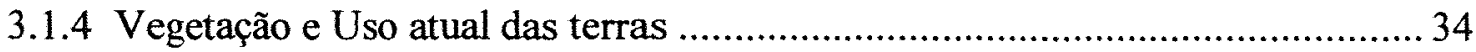

3.1.5 Geologia e Material de origem dos solos .................................................... 36

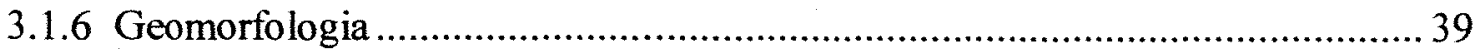

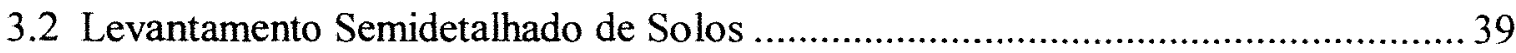




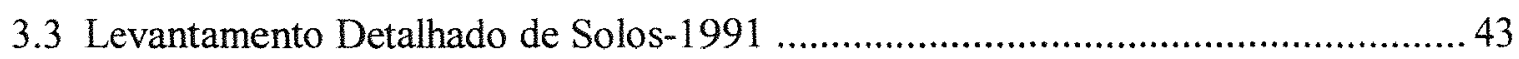

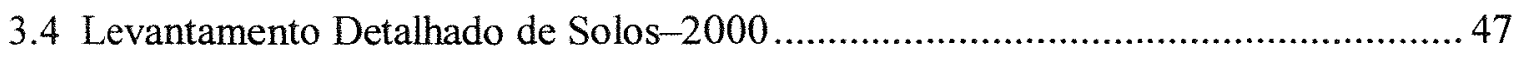

3.4.1 Materiais cartográficos básicos.................................................................. 47

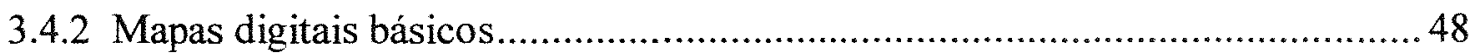

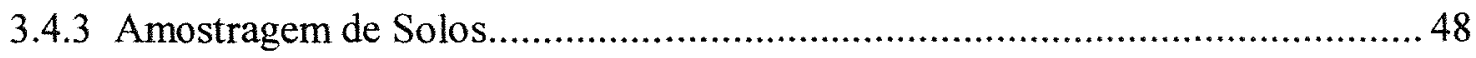

3.4.4 Georeferenciamento da Amostragem de Solos........................................... 51

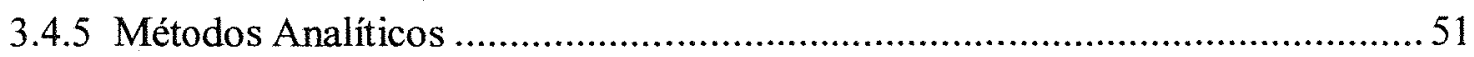

3.4.6 Critérios, definições e conceitos para estabelecimento das classes de solos e

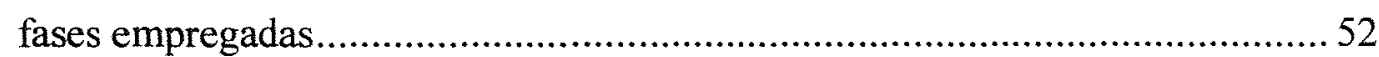

3.5 Comparação e qualidade dos mapas de solos......................................................5 55

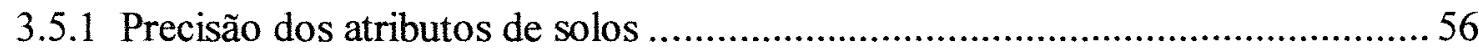

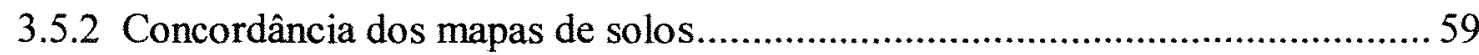

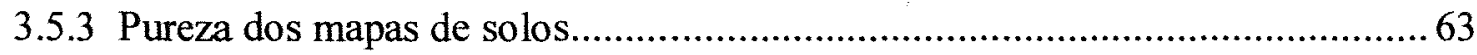

3.5.4 Relação entre pureza e concordância dos mapas de solos................................ 64

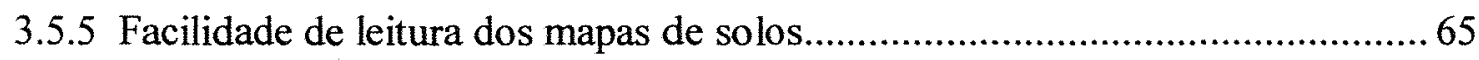

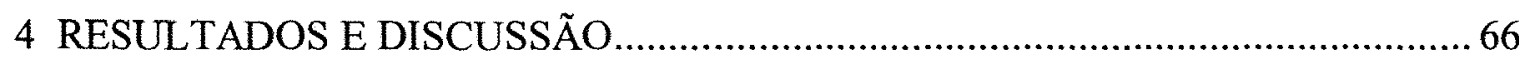

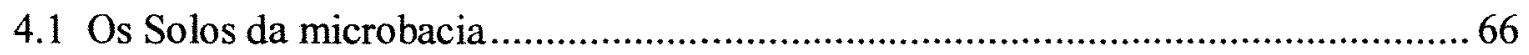

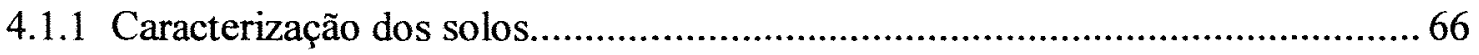

4.1.2 Equivalência (correlação) dos solos da microbacia no Sistema Brasileiro de

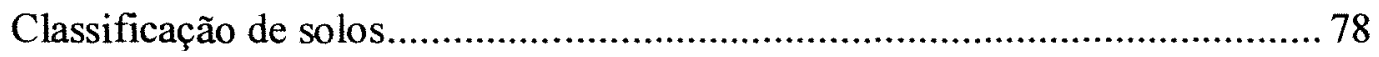

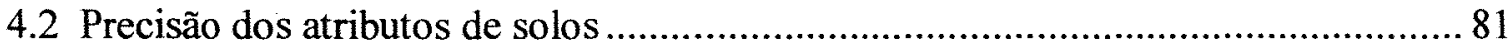

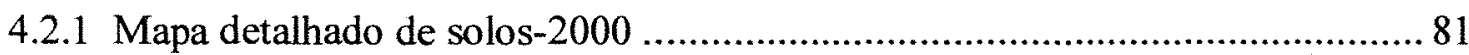

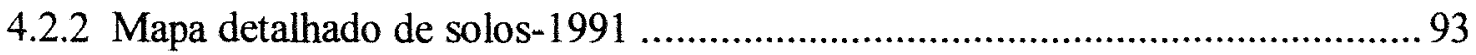

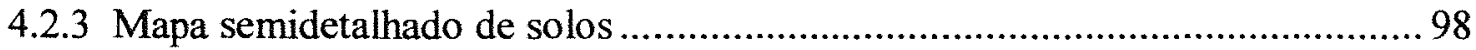

4.2.4 Variabilidade do solo a curta distância - "Grid" .......................................... 103

4.2.5 Comparação da variabilidade entre os mapas de solos .................................. 105

4.2.6 Teste t para comparação entre unidades de mapeamento nos mapas de solos 108

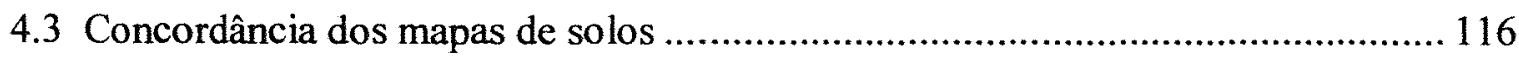

4.3.1 Concordâncias entre o mapa detalhado-2000 e mapa semidetalhado............. 116

4.3.2 Concordâncias entre o mapa detalhado-1991 e o mapa semidetalhado .......... 119 
4.3.3 Concordâncias entre o mapa detalhado-2000 e mapa detalhado-1991 121

4.3.4 Relação entre variabilidade das unidades de mapeamento e concordância dos mapas 124

4.4 Pureza dos mapas de solos 126

4.4.1 Representatividade da amostragem externa 126

4.4.2 Pureza do mapa semidetalhado de solos 130

4.4.3 Pureza do mapa detalhado de solos-1991..... 131

4.4.4 Pureza do mapa detalhado de solos-2000. 132

4.4.5 Avaliação geral da pureza. 135

4.4.6 Relação entre pureza e concordância dos mapas de solos. 136

4.5 Facilidade de leitura dos mapas de solos 138

5 CONCLUSÕES 140

ANEXOS 142 


\title{
MAPAS DE SOLOS PRODUZIDOS EM ESCALAS E ÉPOCAS \\ DISTINTAS
}

\author{
Autor: ENIO FRAGA DA SILVA \\ Orientador: Prof. Dr. GERD SPAROVEK
}

\section{RESUMO}

Este trabalho trata da comparação de três mapas de solos em relação à precisão $\mathrm{e}$ acurácia das unidades de mapeamento e concordância espacial entre os mapas. Para tanto foram utilizados: mapa semidetalhado produzido em 1989, escala 1:100.000; mapa detalhado produzido em 1991, escala 1:10.000; e mapa detalhado produzido em 2000, escala 1:10.000. A área de estudo foi a microbacia hidrográfica do Córrego do Ceveiro, que é um afluente do Rio Piracicaba, localizada no Município de Piracicaba SP, Brasil. A microbacia possui 1990,4 ha e é dominantemente cultivada com cana-deaçúcar. Os solos com horizonte $\mathrm{B}$ textural são dominantes na microbacia, ocupando $43 \%$ da área, com predomínio dos ALISSOLOS CRÔMICOS (20\% da área). Os NEOSSOLOS LITÓLICOS ocorrem em $35 \%$ da microbacia. Houve dificuldades em mapear os solos com horizonte B textural, ao nível de ordem no Sistema Brasileiro de Classificação de Solos, devido a alta variabilidade dos atributos de solos utilizados na classificação, tais como: atividade de argila; saturação por bases; e saturação por alumínio. Como resultado do mapeamento e classificação dos solos, algumas classes de solo nos níveis de subordem, grande grupo e subgrupo são sugeridas para inclusão no Sistema Brasileiro de Classificação de Solos vigente. A precisão das unidades de mapeamento foi determinada pela variação de alguns atributos de solos, medidos pelos coeficientes de variação e uniformidade. A concordância espacial foi avaliada através de uma matriz de sobreposição. A pureza (acurácia) dos mapas, foi quantificada através 
de uma nova sondagem. A área apresenta uma complexa distribuição de solos, devido, principalmente, ao material de origem. A variação dos atributos de solos é elevada, mesmo à curtas distâncias, porém, o detalhamento do mapa foi eficiente em reduzir a variância das unidades de mapeamento e do mapa. A concordância entre o mapa semidetalhado e os mapas detalhados-2000 e 1991 é muito baixa, demonstrando que o mapa semidetalhado não é uma simplificação do mapa detalhado. A concordância entre os mapas detalhados é baixa, indicando que o mapeamento é influenciado pelos recursos disponíveis (cartográficos e quantidade de amostras analisadas) e pela equipe executora. Os mapas detalhados apresentaram maior pureza do que o mapa semidetalhado, sendo que o mapa detalhado-2000 apresentou maior acurácia que o mapa detalhado-1991. As áreas com alta concordância entre os mapas apresentaram alta pureza, e áreas com baixa concordância apresentaram baixa pureza. Foi constatada uma relação inversa entre a facilidade de leitura dos mapas de solos e a qualidade dos mapas medida pela precisão e acurácia. 


\section{SOILS MAPS PRODUCED AT DIFFERENT SCALES}

\section{AND DATES}

Author: ENIO FRAGA DA SILVA

Adviser: Dr. GERD SPAROVEK

\section{SUMMARY}

The objective of this work is the comparison of three soil survey maps in relation to precision and accuracy of the mapping units and spatial concordance between the maps. Three soil maps were used: semi-detailed map produced in 1989, scale 1:100.000; detailed map produced in 1991, scale 1:10.000; and detailed map produced in 2000, scale 1:10.000. The study area was the Ceveiro watershed, a tributary of the Piracicaba river, situated in the county of Piracicaba - SP, Brazil. The watershed has 1990,4 ha and it is dominantly cultivated with sugarcane. The predominant soils are those with argillic horizons, occupying $43 \%$ of the area, among which predominates ALISSOLOS CRÔMICOS (20\% of the area). The NEOSSOLOS LITÓLICOS occur in $35 \%$ of the watershed. It was difficult to map the soils with argillic horizons down to the order level in the Brazilian Soil Classification System due to the high variability of the soil attributes used in their classification, such as: clay activity, base saturation, and aluminum saturation. As a collaboration to the recently developed Brazilian System of Soil Classification, soil taxa at the suborder, great group and subgroup levels are suggested to be included. The precision of the mapping units was determined by the variation of some soil attributes, measured by the coefficients of variation and uniformity. The spatial concordance was evaluated using an overlap matrix. The purity (accuracy) of the maps was quantified by a new survey. The area shows a complex distribution of soils, due mainly to the parent material. The variability of the soil 
attributes is large, even at short distances. However, the detailed survey was efficient in reducing the variance of the mapping units and the map. The concordance between the semi-detailed and the detailed surveys is little, indicating that mapping is influenced by the available resources (cartographic and quantity of samples taken) and by the survey team. The detailed maps showed higher purity than the semi-detailed survey. The 2000 detailed map displayed higher accuracy than the 1991 detailed map. The areas with high concordance between the maps showed high purity, and areas with low concordance showed low purity. An inverse relationship was found between the readability of soil maps and the map quality as measured by map precision and accuracy. 


\section{INTRODUÇÃo}

Nos últimos anos diversos trabalhos têm questionado a necessidade de se fazer levantamentos de solos. Recentemente, o Boletim Informativo da Sociedade Brasileira de Ciência do Solo trouxe o tema "O futuro da pedologia no Brasil", e lançou a pergunta "É necessário continuar fazendo levantamento de solos no Brasil?" Motivados por essa questão propôs-se este trabalho de comparação de mapas de solos. Utilizaram-se dois mapas já existentes, um ao nível de semidetalhado, e outro ao nível de detalhado, e um terceiro mapa, também, ao nível de detalhado, feito para subsidiar este trabalho.

Respondendo a questão acima, o autor acha que os levantamentos de solos são fundamentais para o planejamento agrícola e ambiental de uma região, permitindo o seu desenvolvimento sustentável, uso racional e conservação dos recursos naturais. Porém, as informações de solos existentes hoje no pais, na maioria dos casos, são adequadas para avaliar o potencial de solos em nível estadual ou regional, mas não permitem o planejamento de uso em microbacias hidrográficas, projetos de manejo e conservação do solo, de assentamento de agricultores, de seleção de áreas para descarte de resíduos e outros fins específicos.

A evolução histórica dos levantamentos de solos mostra que os sistemas de classificação taxonômica e de métodos de mapeamento, desenvolvidos para levantamentos de reconhecimento carecem de revisão, atualização e de detalhamento para satisfazer os requisitos de levantamentos mais detalhados de solos; portanto tornase necessário a pesquisa de critérios taxonômicos e de técnicas de mapeamento.

Os sistemas atuais de classificação de solos são baseados nos atributos dos solos observados e/ou medidos que refletem relações genéticas, ou seja, naqueles atributos que 
refletem o resultado de eventos anteriores. A ênfase não é dada para adoção dos critérios quantitativos de diferenciação de classes de solos.

Por sua vez, as informações geradas por levantamentos de solos necessitam ser cada vez mais precisas e exatas (alta acurácia), terem maior confiabilidade das interpretações e maior rapidez na obtenção de dados, com redução de tempo, de custos de pesquisa e de serviços.

A importância deste trabalho está relacionada com o questionamento do mapeamento de solos, em escala detalhada, onde é necessário trabalhar com variabilidade real e a curta distância. Pretende-se mostrar, também, a dificuldade de fazer mapeamento em áreas de alta variabilidade e o ganho de qualidade com o aumento da escala de trabalho.

Este trabalho teve como objetivo comparar mapas de solos produzidos em escalas e épocas distintas em relação a concordância espacial, precisão (variabilidade) e acurácia das informações de solos, visando a melhoria da qualidade de mapeamento de solos. A hipótese principal se refere aos levantamentos de solos tradicionais: assume-se que estes mapeiam unidades de solos baseados em características morfogenéticas, desconsiderando características importantes que possuem alta variabilidade; e os mapas são pouco mutáveis, pois são baseados em características morfogenéticas dos horizontes diagnósticos, não ocorrendo influência de escala e do pedólogo executor no resultado final de um mapa de solos, uma vez que a realidade terrestre permanece a mesma.

As hipóteses secundárias deste trabalho são: os mapas em escalas menores são modelos simplificados daqueles em escalas maiores; não ocorrem diferenças nos resultados finais dos mapeamentos executados por diferentes equipes de pedologia, contanto que não exista diferença na sua qualificação; o levantamento de solos agrupa as unidades de solos de forma a permitir uma múltipla utilização da informação, refletindo os critérios adotados no sistema de classificação (morfogênese); a variância interna das unidades de mapeamento diminui e a acurácia aumenta quando se aumenta o nível de detalhamento do levantamento. 


\section{REVISÃO DE LITERATURA}

\subsection{Histórico do levantamento de solos}

Os solos são corpos naturais individualizados que resultam da ação integrada do clima e dos organismos sobre o material de origem, em dado tempo e lugar. Dockuchaiev (1846-1903), na Rússia em 1880, lançou as bases da Pedologia ou Ciência do Solo e da classificação genético-morfológica dos solos, ao enfatizar a importância do clima e organismos, época em que já se reconheciam os efeitos da rocha matriz, como fator de formação do solo. Posteriormente Milne (1935) mostrou haver estreita relação entre a gênese dos solos e posição na paisagem, principalmente em regiões tropicais com relevo ondulado. Jenny (1941), sintetizou as informações até então conhecidas, na seguinte expressão: $s=f(m o, c, o, r, t)$, sendo que: $\mathrm{s}=$ solo, mo $=$ material de origem, $\mathrm{c}$ $=$ clima, $0=$ organismos, $\mathrm{r}=$ relevo e $\mathrm{t}=$ tempo.

As classificações de solo podem ser interpretativas e taxonômicas (Oliveira, 1972). As classificações interpretativas são aquelas que agrupam os solos de acordo com características para usos específicos, como por exemplo, Aptidão agrícola das terras (Ramalho \& Beek, 1995) e Capacidade de uso das terras (Lepsch et al., 1991). As classificações taxonômicas, surgidas após os preceitos de Dockuchaiev, constituem segundo Cline (1949) no arranjamento de solos em grupos e em ordens sucessivas que permitam reconhecer facilmente suas propriedades e compreender suas relações.

Grande parte da simbologia adotada atualmente em levantamentos pedológicos, está conforme ou são derivadas de outros sistemas, principalmente do "Soil Survey Manual" (Estados Unidos, 1993) e FAO (1974). 
Baldwin et al. (1938) formularam as bases do antigo sistema americano que foi modificado por Thorp e Smith (1949) e evoluiu para a "Soil Taxonomy" (Estados Unidos, 1975). A antiga classificação americana foi nacionalizada e utilizada em quase todos os levantamentos de solos no Brasil. Após várias modificações surgiram as normas descritas pela Embrapa (1988); o levantamento semidetalhado realizado por Oliveira \& Prado (1989) e o levantamento detalhado-1991 realizado por Sparovek (1991) tiveram como base essas normas.

Finalmente, após várias discussões e aproximações, foi publicado o Sistema Brasileiro de Classificação de Solos (Embrapa, 1999). O levantamento detalhado de solos-2000, realizado para o presente trabalho, utilizou as classes de solos preconizadas pelo Sistema.

\subsection{Conceitos Básicos}

Levantamentos de solos são investigações de campo e laboratório que se propõe a avaliar os recursos de solo de uma área para fins gerais ou específicos. Os métodos de execução variam em maior ou menor grau, mas, algumas etapas de execução são comuns a todos os levantamentos e contemplam, necessariamente, a caracterização morfológica, física, química e mineralógica dos solos, a classificação em sistemas definidos e a distribuição espacial (Santos, 1978).

Os levantamentos têm se fundamentado em dois elementos principais. Um consiste da investigação, classificação e interpretação de dados básicos de campo. $O$ outro, consiste no estudo das relações entre estes dados e a distribuição geográfica dos solos representada em mapas (Rourke, 1977).

De acordo com a Embrapa (1988), o objetivo principal dos levantamentos de solos é a divisão de áreas heterogêneas em parcelas homogêneas, através de parâmetros de classificação definidos e das características utilizadas para distinção dos solos em função da escala de mapeamento. 
Tradicionalmente, os levantamentos de solos são baseados em classificações que distinguem classes supostamente homogêneas, unidades discretas, com limites abruptos entre si e representados em mapas, conforme Webster (1977). Sabe-se que para uma unidade de solo figurar num mapa pedológico ela deve apresentar uma certa homogeneidade e ser claramente individualizada no campo o que às vezes torna-se difícil em função da variação espacial que os solos possam apresentar (Adams \& Wilde, 1980; Beckett e Webster, 1971; Olmos Iturri Larach, 1983). Assim sendo, muitas vezes aparecem nos mapas pedológicos associações e/ou grupamentos indiscriminados de solos, conforme foi constatado por Oliveira \& Prado (1989), quando estudaram ao nível semidetalhado, os solos da folha de Piracicaba-SP. Sparovek (1991) encontrou os mesmos problemas ao mapear, ao nível de detalhado, a microbacia hidrográfica do Córrego do Ceveiro.

\subsection{Metodologias usuais de levantamento de solos.}

Métodos tradicionais de mapeamento de solos apoiam-se em observações de campo, em número e intensidade por área conforme a escala e o nível de detalhe esperado. Estes métodos foram sempre fundamentados em observações pontuais (observações por pontos em uma quadrícula), observações ao longo de transectos que cruzam uma paisagem (observações por linhas) e observações por área selecionada para estudos mais detalhados (área piloto), conforme Santos (1978).

Desde 1930, a utilização de fotografias aéreas nos Estados Unidos acelerou a execução de levantamentos em diversos níveis e escalas, substituindo os mapas planialtimétricos, às vezes confeccionados pelos próprios pedólogos. Os progressos daí para frente foram notáveis, acompanhando o desenvolvimento tecnológico e o aperfeiçoamento de sensores colocados em aviões e satélites (Estados Unidos, 1993).

Um método muito difundido tenta identificar a ocorrência natural de unidades geoambientais que podem ser reconhecidas, descritas e mapeadas em termos da total integração de atributos de geomorfologia, geologia, solo, vegetação e água, o que foi designado por Zinck (1990), de "complexo correlato". Outro exemplo é o levantamento 
integrado de recursos naturais da Austrália ("land systems") que identifica, descreve e mapeia, grandes segmentos integrados de paisagem.

O principal problema com os levantamentos integrados é que eles acabam por ser muito generalizados, dificultando a recuperação de informações específicas sobre atributos particulares da paisagem. Desta forma é deixado espaço para levantamentos convencionais monodisciplinares, tais como, geologia, geomorfologia, solo, vegetação e uso da terra, com tendências a escalas cada vez maiores de acordo com as demandas de uso e manejo de recursos naturais. Quando houver disponível, levantamentos monodisciplinares, o usuário pode combinar as informações para produzir uma visão integrada da paisagem, podendo, a critério próprio, reclassificar ou generalizar (Burrough, 1986).

Os métodos de levantamentos de solos têm passado por vários ajustes e aperfeiçoamentos ao longo de anos e um modelo básico é descrito por Zinck (1990), hierarquizando as diversas etapas de execução, desde a coleta de dados, passando pelo processamento, interpolação e a aplicação no planejamento de uso da terra.

Bhering (1995), abordou aspectos organizacionais de sistema de informação de solos, propondo uma base de dados, incorporando mapas, pontos amostrais, unidades de mapeamento, constituindo, desta forma, o modelo básico do SIGSOLOS (SIG em implementação e validação pela Embrapa Solos).

A organização de bases de dados de solos, conforme propostas por Zinck (1990) e Bhering (1995), são propostas concretas, atualmente viáveis, cujos impactos logo influenciarão as metodologias de execução de mapeamentos, conduzindo a adaptações e modernização de processos de captação de dados.

\subsubsection{Métodos de Prospecção (Embrapa, 1995)}

Os métodos de prospecção utilizados em levantamentos pedológicos visam a coleta de dados, descrição de características dos solos no campo e a verificação de limites entre unidades de mapeamento e compreendem as investigações ao longo de 
transectos, levantamentos de áreas piloto, estudo de topossequências, sistema de malhas e o método do caminhamento livre.

No método de investigações ao longo de topossequências, os solos e suas variações são correlacionados com as superfícies geomórficas em que ocorrem. Por este método é possível estabelecer correlações entre classes de solos, textura, drenagem, profundidade (ou outras características), declive, comprimento e forma de pendentes, posição e exposição dos solos em relação às encostas. É o método de prospecção mais apropriado para execução de levantamentos pedológicos detalhados.

Em levantamentos detalhados e ultradetalhados, em escalas grandes, para projetos de uso intensivo dos solos, é usual a utilização de sistemas de malhas (grid) no planejamento de coleta de amostras, observações de campo e estudo da variabilidade dos solos. Este método consta, essencialmente, de observações a espaços prefixados de modo a formar um reticulado denso (malha) em toda a extensão da área. Por este método a fotointerpretação é utilizada para estimativa do grau de heterogeneidade da área, em combinação com observações de campo.

\subsubsection{Densidade de Observações}

Não há consenso quanto à densidade de observações a serem estabelecidas para levantamentos pedológicos (Breimer et al., 1986). São registrados, por diversos autores, em várias partes do mundo, números que variam de 0,25 a 5 observações por $\mathrm{cm}^{2}$ de mapa. Todos concordam que são números teóricos, e que a densidade de observação é função dos objetivos do levantamento, da escala de mapeamento, da extensão e da homogeneidade ou heterogeneidade da área de trabalho.

Para atender aos diversos níveis de levantamentos pedológicos, em diversas escalas, a densidade de observações é calculada, tomando-se por base as menores dimensões que podem ser legivelmente delineadas em um mapa, sem prejuizo da informação gerada no levantamento, considerada ser uma área de aproximadamente 0,4 $\mathrm{cm}^{2}$. A equivalência desta área no mapa, com a superficie correspondente no campo, é dada pela fórmula: 


$$
\mathrm{AMM}=(\mathrm{E} \times \sqrt{ } 0,4 / 100)^{2}, \text { sendo: }
$$

$\mathrm{AMM}$ = área mínima mapeável no campo em metros quadrados;

$\mathrm{E}=$ escala de publicação.

Para levantamentos detalhados recomendam-se 0,2 observações por área mínima mapeável, o que significa 0,5 observação por hectare, para uma escala de publicação de $1: 10.000$.

\subsubsection{Escala do Material Básico}

A escala do material básico deve ser selecionada tendo em vista a compatibilização cartográfica entre níveis de detalhe ou generalização previstos para o levantamento e o mapa final de solos a ser apresentado. Normalmente deve ser um pouco maior que a escala final de publicação. Dent \& Young (1981) recomendam a utilização de mapas básicos em escala 2 ou 2,5 vezes maior do que a escala de publicação. No entanto, deve-se levar em conta o tempo de execução e os custos de levantamentos mais detalhados do que o necessário para cumprir os objetivos previstos do levantamento.

\subsubsection{Tipos de Levantamentos}

O tipo de levantamento pedológico a ser executado deve ser decidido levando-se em conta o trinômio escala-precisão-objetivos.

Os levantamentos de solos comumente executados são os esquemáticos, os exploratórios, os de reconhecimento, os semidetalhados e os detalhados (Olmos Iturri Larach et al., 1981). Estes autores indicam que, nos levantamentos esquemáticos, a área mínima mapeável deve ser superior a $40 \mathrm{~km}^{2}$, resultando em um mapa de escala igual ou inferior a 1:1.000.000; nos exploratórios, trabalha-se com uma área mínima na faixa de 22,5 a $250 \mathrm{~km}^{2}$, fornecendo-se os dados em mapas com escalas na faixa de 1:750.000 a 1:2.500.000; nos de reconhecimento, tem-se como área mínima mapeável a faixa de 0,4 a $22,5 \mathrm{~km}^{2}$, dispondo-se de mapas com escalas na faixa de 1:100.000 a 1:750.000; nos 
semidetalhados, trabalha-se com áreas mínimas na faixa de 2,5 a 40 ha, com mapas na faixa de 1:25.000 a 1:100.000; e, finalizando no levantamento detalhado, emprega-se área inferior a 2,5 ha, fornecendo mapas de escalas superiores a 1:25.000.

Infere-se do trabalho de Olmos Iturri Larach et al. (1981), embora com base em dados levantados há vários anos, que os levantamentos de solos a níveis semidetalhado $\mathrm{e}$ detalhado correspondem a mais ou menos $0,25 \%$ da área do país. No nível de reconhecimento havia sido levantado $17,1 \%$ e no nível exploratório já havia sido levantado, até aquela data, $75,6 \%$ da área total do país. Segundo esses autores, encontrase em disponibilidade dados pedológicos da maior parte do território nacional, contidos em mapas de solos e textos explicativos, mas as informações são de caráter generalizado e não mantém o mesmo grau de uniformidade. Sendo assim, não se espera que essas informações de caráter generalizado conduzam a soluções de problemas específicos, mas sim à solução de problemas de caráter também generalizado.

\section{a) Levantamento Semidetalhado}

São executados para fins de avaliação qualitativa e semiquantitativa do recurso solo, visando a estimativa de potencial de uso agrícola e não agrícola.

As classes de solos acumulam características utilizadas nos levantamentos exploratórios e características que expressam diferenciação de horizontes diagnósticos, transformação dos constituintes do solo e constituição pedogenética expressa por propriedades decorrentes da natureza das argilas e saturação do complexo sortivo.

O levantamento de solos existente na região de Piracicaba é semidetalhado, com publicação na escala de 1:100.000, apresentando aproximadamente 0,35 observações de campo/40 ha (AMM), e foi executado pelo Instituto Agronômico de Campinas (Oliveira \& Prado, 1989).

\section{b) Levantamento Detalhado}

O levantamento realizado na microbacia hidrográfica do Córrego do Ceveiro foi ao nível de detalhado. A escala de publicação é de 1:10.000, com área mínima mapeável 
de 0,4 ha e aproximadamente 0,2 observações por AMM. A freqüência de amostragem foi suficiente para detectar diferenças de solos em pequenas áreas, sendo utilizados, no mínimo, um perfil completo e 2 dois perfis complementares para caracterização das classes de solos identificadas no nível taxonômico mais baixo.

As unidades de mapeamento são definidas e conceituadas em termos de características compatíveis com o nível categórico mais baixo de sistemas hierárquicos de classificação de solos.

As fases utilizadas em levantamentos pedológicos estão definidas na Súmula da X Reunião Técnica de Levantamento de Solos (1979) e no Sistema Brasileiro de Classificação de Solos (Embrapa, 1999).

\subsection{Métodos modernos de levantamento de solos}

Mais recentemente, pesquisas em metodologias de mapeamento têm direcionado mais atenção para técnicas inovadoras, utilizando os conhecimentos disponíveis em geoestatística, sistemas geográficos, sensoriamento remoto por satélite, processamento digital, recursos de vídeo imagem, radar de penetração, laser, com melhoria do processo de coleta de dados e organização das etapas do levantamento de solos como um verdadeiro sistema de informação (Zinck, 1990).

Uma nova estrutura de aquisição e de disseminação de informação de solos foi proposta por Indorante et al. (1996), baseada na revisão de levantamentos já realizados, incluindo a digitalização de mapas, atributos do terreno, dados climáticos, imagens, informações ambientais, constituindo uma base de dados de caráter dinâmico que pode ser atualizada e reinterpretada a qualquer momento. Ananko et al. (1998), com base em classificação múltipla de solos (pedogenética, litogênica e funcional - expressando as condições atuais do solo, como regimes de umidade e temperatura), apresentaram uma abordagem em que diferentes mapas podem ser analisados simultaneamente, resultando em maior quantidade de informação para diversos usuários.

$\mathrm{O}$ rápido progresso no uso de sensoriamento remoto impulsionou o desenvolvimento de métodos de processamento e análise de dados da superficie da terra. 
Avanços mais significativos são esperados devido à contínua integração das tecnologias de sensoriamento remoto, sistemas de informações geográficas (SIGs) e o sistema de posicionamento global (GPS) (Hoffer, 1994).

As imagens de satélites passaram a ser utilizadas no mapeamento de solos a partir do início da década de setenta. Desde aquela época os mapas espectrais têm se mostrados úteis na avaliação de algumas propriedades dos solos tais como cor (Post, 1984 e Post et al., 1994), no delineamento dos limites das unidades de solo e na avaliação da homogeneidade das unidades presentes nos mapas de solos (Agbu et al., 1990). Na opinião de alguns autores, entretanto, o sucesso no delineamento das unidades de solo com base na resposta espectral requer homogeneidade dentro das unidades e dissimilaridade espectral entre estas mesmas unidades (Cihlar \& Protz, 1973). Estes autores relataram que apenas a resposta espectral não foi suficiente para a produção de mapas de solos precisos da área trabalhada, mas que as diferenças espectrais proporcionam uma informação adicional sobre a distribuição dos solos.

Métodos de mapeamento com base no conhecimento de ocorrência de padrões regionais de solos podem utilizar informações previamente geradas em pequenas áreas representativas, conhecidas como áreas referência. A grande vantagem do método é permitir a previsão de ocorrência de tipos de solos em outras áreas não mapeadas, por correlação com os padrões conhecidos nas áreas referência. Comparações entre mapas de solos reais e simulados mostraram-se promissoras, em áreas de padrões de solos identificáveis e repetitivos (Lagacherie et al., 1995).

Uma nova abordagem do levantamento de solos é o crescente uso de modelos solo-paisagem combinado com uma hierarquia dos levantamentos, que está tornando-se reconhecida como novo paradigma do levantamento de solos, e para entendimento e predição de modelos naturais de solo (Hudson, 1992).

Os modelos solo-paisagem são utilizados para aumentar o entendimento da relação espacial entre os atributos da paisagem e modelos de solos. Eles podem ser combinados com modelos digitais de elevação e SIG para aumentar a eficiência dos modelos de mapeamento de solos (Harmsworth et al., 1995). 
Burrough (1993) sugeriu que os levantamentos de solo devem adotar um processamento mais quantitativo baseado no enfoque orientado a processos para interpretação dos processos de solos e paisagens, para explicar a complexidade e variabilidade dos solos nas várias escalas de tempo e espaço.

Uma investigação por Leenhardt et al. (1994), para avaliação da eficiência da capacidade de previsão de um levantamento pedológico, mostrou variações em função da classificação e da escala, com mais acertos se a classificação conseguiu reduzir a variância e menor eficácia quanto menor a escala do mapa. O estudo comprova a necessidade de diminuir a variância interna de unidades de mapeamento no que se refere a uma gama de propriedades associadas a uma determinada classe de solos.

Estudos recentes por Voltz et al. (1997) enfatizaram a linha de capacidade de previsão dos levantamentos, assim como, métodos para mapear propriedades específicas de solos usando krigeagem, inverso da distância ao quadrado e critérios de vizinho mais próximo.

Vários trabalhos têm mostrado que a variabilidade do solo não é puramente aleatória, apresentando correlação ou dependência espacial (Burrough, 1991; Goovaerts, 1999; Vieira et al., 1981 e Vieira et al., 1983). A caracterização ordinária da variabilidade espacial pode ser efetuada através do cálculo do autocorrelograma, do semivariograma, da análise espectral e da krigeagem (Libardi et al., 1986; Vieira et al., 1981 e Vieira et al., 1983). A existência de dependência espacial indicada pelo semivariograma é suficiente para aplicação do método da krigeagem, para interpolação de medidas efetuadas no campo, sem tendência e com variância mínima (Vieira, 1997; Voltz et al., 1997).

Algumas pesquisas recentes indicam a possibilidade de uso de ferramentas de geoestatística (Brubaker \& Hallmark, 1991; Burrough, 1991; Goovaerts, 1999; Vieira et al., 1981 e Vieira et al., 1983) e métodos de lógica fuzzy (Burrough, 1989) aplicados ao mapeamento de propriedades do solo. Em uma abordagem prática, comparando métodos clássicos da lógica booleana, para separação de classes, Braga \& Fuks (1993) e Oliveira et al. (1992), elaboraram mapas de fertilidade e umidade do solo, mostrando que mapas 
obtidos através da classificação fuzzy podem aumentar as possibilidades de dedução e inferências para diversas interpretações.

A automação, segundo Burrough (1986), acompanhada da necessidade da análise de dados espaciais, viabiliza a integração de diferentes aspectos da superfície da terra, permitindo a elaboração de mapas mais precisos, de execução mais rápida e mais adequada a qualquer tipo de usuário e podendo ser atualizado a qualquer tempo. A automação poderá levar a uma total revisão dos processos de mapeamento e, consequentemente, à significativa economia de tempo e recursos.

Com o avanço da informática, o armazenamento dos dados originalmente observados e mensurados de forma correta e devidamente georeferenciados tem tido maior prioridade que a classificação de solos (De Bie et al., 1996).

Observa-se tendência nos estudos relacionados à avaliação de terras de se tornarem cada vez mais quantitativos, especialmente se estes procuram integrar aspectos econômicos ou fisicos ligados a sua aptidão produtiva com a preservação ambiental de seus recursos naturais (Diepen et al., 1991). Observação semelhante foi apontada por Bouma (1989), indicando a necessidade de levantamentos de solos que possibilitem a avaliação de terras de forma quantitativa. No mesmo sentido, Indorante et al. (1996) afirmaram que os produtos do levantamento de solos devem ser mais quantitativos, de fácil entendimento para o leigo e capaz de incorporar novos dados coletados em escalas maiores.

Aplicações do levantamento de solos tem sido voltado, tradicionalmente, para o uso agrícola, embora agora haja aumento na tendência de aplicações para avaliações de engenharia, aptidão para depósitos de resíduos e efeitos ambientais do uso da terra no solo (Zinck, 1994), requerendo escalas apropriadas de investigação e coleta de dados específicos. Talvez um dos maiores desafios seja a integração de informações coletadas em diferentes escalas, e incluindo diferentes ajustes de parâmetros, dentro de um SIG e sistemas de informações de solos aonde seja prontamente acessível. 
É importante lembrar que embora a adoção da tecnologia do SIG tenha feito a reclassificação, interpretação e desenho do mapa mais fácil e barato, ela não adquire novas informações como o solo varia no espaço e no tempo. Salienta-se o perigo da ênfase no aumento da aplicação e utilização de informações de solos e o declínio da coleta de dados no campo, já que o aumento de interpretações sofisticadas usando SIG será baseado em dados velhos e inadequados de solos (Basher, 1997).

Há uma contínua necessidade da pedologia para definir a extensão, distribuição, propriedades, aptidão e vulnerabilidade dos solos, como base para um manejo sustentável do solo. Entretanto, necessita ser aumentado o foco nas mudanças temporais das propriedades dos solos, mais atenção para as propriedades dos solos que reflitam o funcionamento e uso do solo, e mais atenção para as informações ambientais contidas no solo e regolito (Basher, 1997).

\subsection{Escalas de Trabalho}

Uma questão a ser discutida quando se trabalha com mapeamento é a adequação no uso das escalas de trabalho. Deve-se salientar que são extremamente escassos os trabalhos que abordam uma discussão sobre as bases para a escolha da escala de trabalho. De maneira geral, a escolha das escalas dos mapas é intuitiva e obedece ao "bom senso" do planejador. Desta forma, pode-se estar muitas vezes perdendo informações importantes utilizando um mapa pouco detalhado ou, ao contrário, detalhando demasiadamente um mapa que posteriormente será reduzido, agrupando ou mesmo perdendo as informações que já foram levantadas (Ranieri, 1996).

A escolha da escala deve levar em consideração os objetivos do estudo e o grau de detalhamento que se pretende obter nos resultados. Escalas maiores permitem um maior número de informações e maior detalhamento. Escalas menores tendem a generalizar e agrupar informações, diminuindo, porém, o tempo e o custo para o levantamento dos dados (Bouma, 1989). Com base nestas afirmações, o pesquisador deve optar por um grau de generalização que, por um lado, seja suficientemente detalhado para permitir resultados mensuráveis, mas que por outro lado, possa ter real 
aplicabilidade no contexto de uma determinada área, evitando excesso de informações que invariavelmente terão de ser agrupadas. Como exemplo, o autor comparou o nível de informações que se pode obter de mapas pedológicos em quatro escalas diferentes $(1: 10.000,1: 25.000,1: 50.000$ e 1:250.000) com o custo para a obtenção destes mapas. Concluiu que o alto custo alcançado pela maior escala foi menos importante que o aumento das informações para responder a questões específicas propostas. E enfatizou que a problemática na escolha da escala de trabalho não depende somente da variabilidade dos solos, mas também do tipo de questão que se quer resolver e da análise da relação custo/benefício para a obtenção de informações.

A comparação entre os resultados obtidos através dos dois métodos e de diferentes escalas de trabalho pode fornecer um indicativo do caminho metodológico a ser seguido quando a unidade em estudo é uma bacia hidrográfica, principalmente com relação ao custo e tempo na obtenção de dados e acurácia nos resultados.

Ranieri (1996), utilizando a metodologia de matriz de "erros" ou matriz de "confusão" na microbacia hidrográfica do Ribeirão dos Marins, localizado em Piracicaba, SP, para comparar um levantamento de reconhecimento na escala 1:100.000 e um levantamento detalhado na escala 1:10.000, mostrou uma coincidência espacial entre as unidades de mapeamento idênticas entre as duas escalas de 19,5\%. Quando foram consideradas unidades de mapeamento com alguma correspondência entre as duas escalas, a porcentagem de sobreposição entre os dois mapas foi muito significativa (68\%). Concluindo que as diferenças encontradas entre os dois mapas estão basicamente na melhor separação entre as unidades ou na melhor definição entre os limites espaciais de cada unidade. Isto significa que $68 \%$ da área da bacia não sofreu alterações significativas quando houve um aumento na escala do mapa pedológico. Por outro lado, $32 \%$ da área sofreu mudança significativa na passagem da escala menor para a maior. Fazem parte desta categoria unidades de mapeamento do mapa detalhado que coincidiram espacialmente com unidades muito divergentes no mapa generalizado ou unidades de mapeamento que foram encontradas somente no mapa detalhado. A origem destes erros está no número limitado de pontos de amostragem no mapa 1:100.000, 
levando à generalização das unidades de mapeamento e à menor precisão dos limites espaciais destas unidades.

Para Schargel (1993) a aplicação das informações de solos são usualmente baseadas em parâmetros qualitativos, os quais não são muito úteis em áreas de uso estável da terra. Respostas quantitativas são possiveis com a melhoria dos levantamentos e procedimentos de interpretação.

Por outro lado, observa-se uma tendência nos estudos relacionados à avaliação de terras de se tornarem cada vez mais quantitativos, especialmente se estes procuram integrar aspectos econômicos ou físicos ligados a sua aptidão produtiva com a preservação ambiental de seus recursos naturais (Diepen et al., 1991). Observação semelhante foi apontada por Bouma (1989), indicando a necessidade de levantamentos de solos que possibilitem a avaliação de terras de forma quantitativa.

\subsection{Medidas de qualidade dos mapas de solos}

A Soil Science Society of America (1995) define qualidade de solo como: "Qualidade de solo é a capacidade de um tipo específico de solo para funcionar, dentro dos limites de ecossistema natural ou manejado, para sustentar produtividade de plantas e animal, manter ou aumentar a qualidade da água e do ar, e sustentar a saúde humana e habitação."

O controle de qualidade em levantamentos de solos teve início a pouco tempo (Marsman \& Gruijter, 1986), mas, aparentemente existem duas alternativas de abordagem para definir e qualificar a qualidade do levantamento: uma é baseada em critérios cartográficos e outra em critérios pedológicos. A qualidade cartográfica de um mapa de solo é avaliada pela facilidade de leitura do mapa (legibilidade); a qualidade pedológica reflete a acurácia e precisão da informação presente no mapa (Becket \& Burrough, 1971; Becket \& Webster, 1971; Bie \& Beckett, 1971; Bie \& Beckett, 1973; Marsman \& Gruijter, 1986; Webster, 1977 e Wilding et al., 1965). Além dessas medidas, a qualidade foi avaliada pela concordância espacial entre os mapas de solos (Bie \& Beckett, 1973; Focht, 1998 e Ranieri, 1996). 
As medidas de pureza têm uma longa tradição em levantamento de solos. Suas definições e interpretações são simples. Essas medidas indicam o grau no qual os critérios de classificação mostrado no mapa são satisfeitos pelas propriedades dos perfis de solos no campo. Elas refletem a acurácia com que as ocorrências de unidades taxonômicas no campo são indicadas no mapa. As desvantagens das medidas de pureza são que todos desvios das classes definidas estão igualmente equilibrados, indiferentes dos seus tipos ou extensão (Becket \& Webster, 1971; Bie \& Beckett, 1971; Bie \& Beckett, 1973; Marsman \& Gruijter, 1986 e Wilding et al., 1965). A pureza só indica até que ponto o conteúdo das áreas delineadas corresponde às especificações no sistema de classificação usado. Porcentagens de pureza indicam a acurácia, mas não necessariamente são relacionadas a aplicações particulares de mapas de solos. Também, pureza não diferencia entre critérios de classificação importantes e menos importantes.

Comparando mapas de solos produzidos por diferentes pedólogos, Bie \& Beckett (1973) utilizaram um grid com 800 perfis para checagem dos mapas. Encontraram purezas médias para unidades de mapeamento de: $32,1 \%$ para o pedólogo $\mathrm{B} ; 47,0 \%$ para o pedólogo $\mathrm{C} ; 56,2 \%$ para o pedólogo $\mathrm{A}$; e $69,2 \%$ para o pedólogo $\mathrm{D}$. O trabalho mostrou como tendência geral do experimento, que o número de classes de solos e a pureza das unidades de mapeamento possuem relação aproximadamente inversa para três pedólogos. Para um dos pedólogos (pedólogo C) o número de unidades de mapeamento e sua pureza mostraram a mesma relação. Similarmente o pedólogo $B$, que empregou a maior quantidade de perfis, porém, com baixa pureza, obteve sucesso em encontrar a maior uniformidade de classes de solos que os outros pedólogos, e consideravelmente mais que o pedólogo A que utilizou poucos perfis. $O$ pedólogo $D$ deixou os solos da grande área central do mapa sem divisão, concentrando esforço em classificar e delinear pequenas áreas de solos contrastantes. Ele obteve a maior pureza. Pois ao mapear solos altamente contrastantes ele obteve relativamente maior redução da variância de muitas propriedades dos solos. Seu mapa parece incomum, com fina subdivisão de áreas obviamente improdutivas e grandes áreas agrícolas não divididas. Contudo, se o propósito de um bom mapa de solos para uso geral é ter alta pureza e grande redução da variância, o pedólogo D parece ter desenvolvido a melhor estratégia. 
Trabalhando com qualidade de solos Marsman \& Gruijter (1986) compararam métodos de levantamento de solos em uma área arenosa na província de Gelderland na Holanda. Mapas de solos foram feitos para a área do projeto, usando diferentes métodos de levantamentos. Para uma área de 1600 ha, seis mapas de solos na escala 1:50.000 foram feitos usando a legenda do mapa de solos da Holanda, escala 1:50.000. Além disso, para uma parte desta área, 400 ha, seis mapas de solos na escala 1:10.000 foram feitos baseados na legenda de mapas detalhados usados pela comissão de Levantamentos. Quatro métodos de levantamento foram aplicados para compilar os mapas de solos, consistindo da combinação de duas alternativas de procedimento de amostragem (Proposto ou randômico) e duas alternativas para o delineamento (campo e proximal - por computador). Perfis de solos descritos, selecionados randomicamente, foram usados como amostra teste para checar a qualidade, 256 perfis para os mapas na escala 1:50.000 e 576 perfis para os mapas na escala 1:10.000; baseados nesta checagem da qualidade, estimativas de 25 critérios de qualidade foram feitas. Dentre os critérios de qualidade, existem 7 medidas de pureza, 2 índices de homogeneidade para aptidão para agricultura, e desvio padrão para 16 variáveis de solos.

Eles encontraram purezas médias variando entre $64 \%$ e $70 \%$ para mapas de solo na escala 1:50.000. Mapas de solo na escala 1:10.000 têm pureza média entre 59\% e $62 \%$. Cinco purezas parciais foram determinadas, cada uma define um subconjunto de todos os critérios dos sistemas de classificações usados. Os seus valores dependem do subconjunto individual de critérios e do método de levantamento aplicado. Os valores extremos são $34 \%$ e 100\% para mapas de solo na escala 1:50.000. Para mapas de solo na escala 1:10.000 estes valores são $43 \%$ e $84 \%$. Valores para pureza ppd (propriamente dita) são todos muitos baixos, variando entre $7 \%$ e $12 \%$. A pureza $p p d$ é quando a classificação do perfil é exatamente igual à classificação da unidade de mapeamento.

A precisão das informações de um mapa de solos é dada pela variação dos atributos de solos dentro das unidades de mapeamento ou dos mapas de solos. Investigações das variâncias de propriedades de solo foram resumidas por Beckett $\mathrm{e}$ Webster (1971). 
Ao discutir precisão, Arnold (1977) colocou em evidência três tipos de informações a serem consideradas na avaliação da qualidade de mapas pedológicos. $O$ primeiro refere-se à exatidão da classificação dos solos em qualquer ponto da área em relação ao sistema taxonômico utilizado. O segundo tipo diz respeito à precisão da locação dos limites entre classes e o terceiro relaciona-se à confiabilidade e precisão dos mapas básicos, nos quais são delineadas as unidades de mapeamento e seus limites.

A influência de pedólogos diferentes foi demonstrada por Bie \& Beckett (1973), que em seus estudos compararam quatro mapas de solos produzidos a partir de fotointerpretação de uma área de Chipre por quatro experientes profissionais da área de cartografia de solos que trabalharam independentemente e sem nenhuma restrição estabelecida. Os resultados demonstraram que os quatro mapas de solos produzidos eram consideravelmente diferentes entre si. Concluíram também que a porcentagem de pureza foi maior e o grau da variabilidade das propriedades dos solos dentro das unidades de mapeamento foi menor do que o da paisagem como um todo.

As medidas de qualidade devem ser relacionadas ao propósito do mapa. Mas o propósito de um mapa nem sempre é conhecido, ou o mapa pode ser usado para propósitos diferentes. Julgamentos da qualidade de um mapa de solo só são válidos para aquelas propriedades que são atualmente utilizadas. A alta acurácia ou precisão para uma propriedade de solo não indica alta qualidade para outras propriedades de solo. Por isto, julgamento geral na qualidade de mapas de solo tem que estar baseado em várias medidas de qualidade de vários tipos (Marsman \& Gruijter, 1986) .

A facilidade de leitura do mapa ou legibilidade é importante quando se consideram usuários tradicionais dos mapas de solos, apresentando menor importância para uso em SIGs. Em geral usuários de mapas preferem mapas de solos com um número limitado de unidades de mapeamento. Eles também não gostam de mapas cujas áreas delineadas são muito pequenas (Marsman \& Gruijter, 1986).

A utilidade dos levantamentos pedológicos é comumente relacionada à confiabilidade das informações apresentadas nos mapas de solos e relatórios descritivos (Santos, 1978). 
Numa revisão sobre aspectos pedológicos dos indicadores de qualidade de solos MacEwan (1997) afirma que não é incomum ouvir comentários negativos sobre a inutilidade dos mapas de solos produzidos, simplesmente porque os críticos, normalmente os usuários dos produtos, e os produtores dos mapas, normalmente uma agência governamental, não vivem ou pensam na mesma escala de planejamento.

\subsubsection{Variação dos atributos do solo}

A variação dos atributos dos solos, frequentemente implica em dificuldades para aqueles que trabalham com mapeamento de solos. Ela pode ocorrer em diferentes niveis e pode estar relacionada a diversos fatores como aqueles de formação tais como mo, $c$, $o, r, t$ (Jenny, 1941) e também ao manejo e uso agrícola (McGraw, 1994).

A variação dos atributos do solo quase sempre se divide em variação sistemática e variação ao acaso. A primeira resulta de diferenças reconhecíveis na taxa de intemperismo, litologia, topografia e hidrologia. A segunda é atribuída às diferenças não conhecidas em tais parâmetros bem como as diferenças devidas a amostragem e erros cometidos em laboratório (Wilding \& Drees, 1983). Ela pode dar-se em grande ou em pequena escala. Em geral as variações em grande escala são determinadas por um pequeno número de fatores, e aquelas em pequena escala (microvariabilidade), são determinadas por um número maior de fatores. Segundo Meentenmeyer \& Box (1987), quanto mais generalizada a escala de interesse, mais significativo é o efeito dos fatores e, menor o número de fatores responsáveis pela variação dos atributos do solo.

Discorrendo sobre as variações dos atributos dos solos em pequena escala, Moormann (1975) citou como as principais causas: variações das propriedades químicas e físicas associadas às variações laterais geogenéticas e pedogenéticas, atuação de plantas que promovem mudanças no solo e, de térmitas, que podem movimentar grandes volumes de solo e a atividade humana. Beckett \& Webster (1971) afirmaram que minhocas escavando afetam volumes pequenos de solo e introduzem diferenças em distâncias muito curtas; outros (como gradientes regionais do clima) introduzem gradações de solo de longo alcance. Esses autores citaram algumas fontes de 
variabilidade em curtas distâncias, como por exemplo: material de origem; topografia; erosão do solo; atividades biológicas; e processos fisico-químicos dentro do solo.

Estudando as relações entre fatores de formação e o próprio solo, Azolin et al. (1978) verificaram que diferentes superfícies geomórficas associadas a diferentes materiais de origem foram as principais condicionantes dos atributos físicos, químicos e morfológicos dos solos, e que os atributos químicos são mais relacionados ao material de origem do que às diferentes superfícies geomórficas. A drenagem, um fator local, também influenciou acentuadamente vários atributos dos solos. Cowie (1980) verificou que a maior parte das diferenças observadas entre os solos estudados deveu-se a variação da espessura da camada superficial naqueles mais jovens. Variações regionais seriam relacionadas à topografia, que por sua vez definiria a direção e intensidade da erosão sobre os referidos solos. Saldaña et al. (1998) observaram uma redução da variabilidade dos depósitos mais novos para os mais velhos, mostrando um incremento da homogeneidade do solo com o tempo.

Em estudo conduzido em uma encosta na parte nordeste do Rio Grande do Sul, Uberti \& Klamt (1984) comprovaram haver estreita relação entre os solos e superficies geomórficas. Cambissolos distróficos medianamente profundos, foram encontrados nos topos entre 400 e $560 \mathrm{~m}$, solos litólicos eutróficos no ombro da encosta entre 85 e $500 \mathrm{~m}$ e brunizens mais desenvolvidos, nos terraços mais estáveis. Diferenças no grau de intemperismo do material de origem, constatadas por Laffan et al. (1986), em uma topossequência, foram relacionadas à história geomórfica e geográfica da paisagem; os solos mais fortemente intemperizados ocorreram até $200 \mathrm{~m}$ de altitude onde o material de origem, provavelmente herdado do pleistoceno interglacial, fora pré-intemperizado. Os solos menos intemperizados ocorreram no topo da paisagem, onde o material de origem teria sido derivado por erosão periglacial durante a última glaciação e por erosão periódica durante o holoceno. Também, Ovalles \& Collins (1986) encontraram estreita relação entre as propriedades dos solos e posição na paisagem, sendo esta relação ainda mais acentuada em função do material de origem e variações da paisagem. Atributos do solo como espessura do horizonte A, cor, teor de areia, teor de carbono orgânico, 
variaram em função do material de origem e da posição na paisagem. Walker et al. (1968) mostraram boas correlações entre parâmetros geomórficos e propriedades dos solos. Os parâmetros geomorfológicos usados foram cota de altitude, gradiente de declive, comprimento da encosta, direção do declive, curvatura da pendente e distância do topo.

Vidal-Torrado \& Lepsch (1993) encontraram elevada correlação entre variações de aspectos do horizonte B (grau de intemperismo, aumento da densidade do solo do topo para a base, atividade da fração argila, índice $\mathrm{Ki}$, estrutura) e posição na vertente. Características granulométricas teriam sido influenciadas pela constituição mineralógica do material de origem (rochas migmatíticas e colúvios). Os autores concluíram que correlações estatísticas entre atributos do solo e parâmetros do relevo, permitem apoiar de forma quantitativa as tendências de variações morfológicas ao longo de topossequências. Certas variações em alguns atributos dos solos, ao longo de uma topossequência, como teor de argila e cor, observadas por Scatolini \& Moniz (1992), foram relacionadas ao material de origem, lençol freático surgente e também à influência da posição na vertente.

Demattê et al. (1992) verificaram que condições climáticas locais, materiais de origem (rocha básica) e a posição na encosta (sopé) condicionaram a drenagem local, influenciando assim decisivamente os atributos e a distribuição dos solos na paisagem.

Coelho et al. (1994) verificaram que diversos atributos dos solos se relacionaram com segmentos geomorfológicos de uma transeção e com o material de origem. Concluíram que a distribuição das classes de solos ao longo da topossequência foi determinada por uma associação de fatores ligados à posição topográfica (processos formadores das diferentes superficies, idade) e ao material de origem.

Embora seja comum, nem sempre a variação dos atributos do solo está relacionada com a posição no relevo ou, este fator nem sempre é o mais importante a influenciar tal variação no solo. A exemplo disso Stolt et al. (1993), estudando as relações solo-paisagem no Piemont, Virgínia-USA, verificaram que a posição na paisagem teve influência mínima ou desprezivel sobre a variação dos atributos mostrada 
pelos solos. Efeitos mais importantes foram atribuídos a diferenças no material de origem ou à diferenças entre horizontes superficiais e subsuperficiais. $\mathrm{O}$ horizonte $\mathrm{C}$, por exemplo, apresentou maior variação lateral do que os horizontes E e B. Isto é, os horizontes mais superficiais são também os mais homogêneos. Também Webb \& Burgham (1994), por sua vez, creditaram a variação de alguns atributos morfológicos do solo, à dinâmica da água e ao transporte de sedimentos. Entretanto nenhuma relação catenária foi verificada quanto a translocação de bases no sistema.

\subsubsection{Variabilidade e Relações Espaciais}

Cline (1944) sugeriu que o trabalho executado em levantamentos de solos, em essência, é a subdivisão de populações heterogêneas (os diferentes solos na paisagem) em estratos mais homogêneos, constituindo o procedimento mais usual para aumentar a acurácia da amostragem de solos para quaisquer fins.

Similarmente, Rigney \& Reed (1945), consideraram o tamanho de áreas em relação a número de observações requerido, subdividindo-as em estratos menores e procedendo a amostragem de cada estrato, para fornecer uma estimativa bastante razoável da homogeneidade de áreas.

Os métodos da estatística tradicional mostram que a variância aumenta com o tamanho da área amostrada, indicando que a variabilidade de propriedades do solo dentro de unidades de mapeamento definidas é diferente nos diversos níveis de generalização (Beckett \& Webster, 1971). Estes autores observaram que as fontes comuns de variabilidade são: material originário dos solos, topografia e atividade biológica.

No Brasil, Lepsch et al. (1977) relataram que maior variabilidade é esperada em superficies geomórficas mais jovens. Foi observado neste estudo que a variabilidade de características de solos foi maior quando as amostras foram agrupadas por superfícies geomórficas. O agrupamento de amostras por características morfológicas produziu populações mais homogêneas. 
De Bie et al. (1996) observaram que os sistemas de classificação de solos atuais são baseados em atributos mensuráveis de solo/terreno os quais refletem as relações genéticas entre os mesmos, isto é, são baseados em atributos que refletem a ação histórica dos fatores de formação. A ênfase não é dada para adoção dos critérios de diferenciação de solos como seria necessário para os usuários da terra.

Tanto os sistemas padrões de classificação de solos quanto os mapas de solos não captam a variabilidade espacial e temporal das características dos solos. $\mathrm{O}$ uso adequado das fases de solo pode preencher esta omissão.

Vários trabalhos mostram que as propriedades do solo e atributos das culturas não variam ao acaso, mas, apresentam algum tipo de correlação ou dependência espacial.

Desta forma, novas opções de delineamento experimental e análise de experimentos têm sido propostos. Nestas, leva-se em consideração a variabilidade espacial dos atributos do solo, ao invés de evitá-las. Para isso a amostragem deve ser realizada de tal forma que a posição de cada amostra seja reconhecida (Vieira \& De Maria, 1996).

Salviano (1996) relacionando atributos de solo e produtividade de Crotalária Juncea em área erodida concluiu que os atributos de solo apresentaram dependência espacial, com exceção do $\mathrm{P}$ subsuperficial e do $\mathrm{K}$ superficial e subsuperficial. Apresentando também como resultado que a espessura do solo, quando superior a $60 \mathrm{~cm}$ não afetou diretamente a produtividade da crotalária, mas quando essa era menor que $20 \mathrm{~cm}$ afetou-a fortemente.

Oliveira (1999) e Berg \& Klamt (1997a e 1997b) observaram que os atributos granulométricos (que são pouco influenciáveis pelo manejo) apresentam menor variação do que os atributos químicos (mais facilmente influenciáveis pelo manejo) tanto no horizonte superficial (A) como no horizonte subsuperficial (B).

Trabalhando em um Latossolo Roxo da região de Campinas (SP), Vieira (1997) observou numa área de $30 \times 30 \mathrm{~m}$ e amostragem de $5 \mathrm{em} 5 \mathrm{~m}$, uma variação de argila, 
silte e atributos químicos, maiores no horizonte $\mathrm{A}$ do que no horizonte $\mathrm{B}$. Ele concluiu que a amostragem ao acaso falharia em detectá-la e, por isso, esconderia a realidade.

A descrição da variação do solo necessita mudar de métodos qualitativos para quantitativos, baseados no entendimento dos processos do solo e paisagem que controlam a variabilidade (Burrough, 1993). Métodos tradicionais de compilação de mapas de solos tendem a ser qualitativos e não guardar informações importantes da variabilidade do solo, resultado em dúvidas sobre a acurácia e confiabilidade dos levantamentos de solos. Entretanto, solos não são corpos estáticos e imutáveis que podem ser claramente escritos por polígonos exatos em um mapa e guardados em um banco de dados; eles são complexos, com fenômenos multivariados que variam em tempo e espaço, e informações da variabilidade do solo são uma importante parte de sua caracterização para predizer como eles responderão a mudanças no uso da terra e condições ambientais (Ibañez et al., 1993). Questões chaves são: quanto varia os atributos do solo; quais são suas taxas de mudança no tempo e espaço; e como esta variação relaciona com outros atributos de solos ou paisagem (Indorante et al., 1996). Técnicas de estatística e geoestatística serão ferramentas importantes para desenhar esquemas de amostragem para mapeamento e caracterização do solo (Brubaker \& Hallmark, 1991; Burrough, 1991; Goovaerts, 1999). Devido a muitas propriedades dos solos variarem continuamente, métodos de classificação contínua (lógica fuzzy) são desejáveis para serem usadas para descrever a variação do solo (Burrough, 1989).

\subsection{O futuro do levantamento de solos}

Vários autores vêm discutindo ultimamente o futuro da pedologia e do levantamento de solos (Basher, 1997; Indorante et al., 1996; White, 1997 e Zinck, 1994). Questões como: Necessidade e importância dos levantamentos de solos? Falta de pedólogos? Pesquisas futuras? São levantadas. 
Arnold (1992) ${ }^{1}$, citado por Basher (1997), sugere que a pedologia é o coração, a alma e a arte da ciência do solo:

- O coração porque ela integra todo os componentes dos solos na paisagem;

- A alma porque ela trata com conceitos da morfologia e gênese do solo;

- A arte porque ela trata com a localização e funções dos solos.

Algumas questões chaves sobre o futuro da pedologia são colocadas por Basher (1997):

(i) Nós precisamos da pedologia e do levantamento de solos? Nós podemos usar o recurso solo de forma sustentável sem o conhecimento de sua extensão, distribuição, propriedades, aptidão e vulnerabilidade para o uso da terra?

(ii) Pode a pedologia ser uma tecnologia-dirigida ou orientada ao usuário?

(iii) Quais são os meios apropriados para apresentar a informação solo?

(iv) Qual é o vocabulário adequado para apresentar a informação solo?

De Bie et al. (1996) levantaram algumas questões importantes quanto ao levantamento de solos: Como as informações sobre o recurso solo podem ser utilizadas para aumentar a sustentabilidade das terras agrícolas? Quais questões devem ser prioritariamente solucionadas em pesquisas futuras?

Em seu trabalho Basher (1997) mostrou a erosão nas pesquisas pedológicas citando a redução nos últimos anos da quantidade de pedólogos e de levantamentos de solos na Nova Zelândia, Austrália e Inglaterra.

Além das razões externas a ciência, como redução de verbas e financiamentos públicos (Zinck, 1994), de acordo com Basher (1997) o declínio nos levantamentos de solos foi devido também ao desenvolvimento do livre mercado, forçando uma mudança na demanda de informações para desenvolvimento da terra e planejamento de uso da

${ }^{1}$ ARNOLD, R.W. Becoming a pedologist. Soil Survey horizons, v.33, p.33-36, 1992. 
terra dos governos federais e regionais para a iniciativa privada e governos locais. Como resultado, houve uma redução da demanda por informações básicas de solos para informações específicas de solos de acordo com o tipo de necessidade e área.

Como consequência, as questões das pesquisas pedológicas estão mudando para novos tópicos:

(i) Pesquisas baseadas em questões locais em vez de dados generalizados: questões de degradação da terra, poluição do solo, e uso sustentável da terra são favorecidas por agências de financiamento em vez de inventário do solo e avaliação de terras;

(ii) Conhecimento das propriedades temporais dos solos para conhecimento das propriedades espaciais dos solos, em particular a relação entre práticas de manejo de solos e impactos no solo para ajudar a prover bases científicas para o uso sustentável da terra.

(iii) Informação da distribuição espacial de propriedades específicas do solo em vez de taxonomia de solo, particularmente para modelagem de solo e dinâmica de água.

No mesmo sentido Klamt (1996) indicou como prioridades de pesquisa na área de levantamento de solos a pesquisa de critérios e variáveis que permitam atualizar e adequar os sistemas de classificação taxonômica e interpretativa a levantamentos mais detalhados de solos e a execução de levantamentos semidetalhados ou detalhados de solos em projetos de microbacias hidrográficas, de assentamento de produtores e áreas prioritárias de desenvolvimento agrícola.

Zinck (1994) listou alguns tópicos relacionados aos levantamentos de solos, que limitam a introdução eficiente de uma moderna tecnologia de informação:

(i) Apresentação inadequada e pouco amigável das informações do solo, por exemplo: mapas, legendas e relatórios; 
(ii) Baixa precisão das informações geográficas dos solos, por exemplo, limite gradual versus abrupto, pretensa homogeneidade das unidades de mapeamento, $\mathrm{e}$ conflitos entre os objetivos gerais vs. os específicos dos levantamentos de solos;

(iii) Custos geralmente elevados dos levantamentos de solos;

(iv) Necessidade de dados primários de precisão definida;

(v) A tecnologia de informações digitais tendo desenvolvimento mais rápido do que pode ser adaptada.

O declínio na pedologia é associado com as grandes mudanças nas prioridades de pesquisa no mundo, uma ênfase na pesquisa aplicada em vez de pesquisa básica e nas questões ambientais, na qual a ciência do solo somente faz parte.

Dumanski (1993) descreveu 5 modelos para a ciência do solo:

(1) Solo como um corpo natural, o tradicional meio de descrição e classificação de solos;

(2) Solo como um meio para crescimento de planta, usado para interpretação das informações dos levantamentos de solos;

(3) Solo como um manto estrutural, usado pela engenharia para interpretação das informações dos levantamentos de solos;

(4) Solo como um manto de transmissão de água, usado para entender o papel do solo no ciclo hidrológico;

(5) Solo como um componente do ecossistema, uma visão holística dos solos.

Ele sugere que os modelos 1 a 3 são tradicionalmente utilizados na pedologia, mas, os modelos 4 e 5 provavelmente serão requeridos no futuro para entender e modelar o comportamento e funcionamento do solo, e para o planejamento sustentável e manejo de terras.

O conhecimento da distribuição e características do solo é um pré-requisito para o planejamento e demonstração do desenvolvimento ecologicamente sustentável (Dumanski, 1993), e o levantamento e caracterização do solo permanecerá importante por essas razões. 
Bouma (1994) sugeriu que a pedologia pode desempenhar um papel na avaliação do uso sustentável da terra, pela:

(i) Expressão quantitativa da resistência e resiliência do solo pelos efeitos do uso da terra para avaliar as interpretações da avaliação de terras;

(ii) Definição das propriedades das unidades de mapeamento do solo;

(iii) Ênfase no aumento do uso de dados existentes de forma mais eficiente através do uso de funções de pedotransferência e na associação das classes taxonômicas, para refletir melhor os atributos funcionais do solo (ex. retenção e movimento da água do solo, traficabilidade, erodibilidade).

As Informações do solo continuarão a ser importantes para o planejamento do manejo sustentável da terra, através da junção do uso da terra com o tipo de solo, resultando na contínua necessidade de levantamentos de solos. 


\section{MATERIAL E MÉTODOS}

\section{1 Área de estudo}

\subsubsection{Localização}

A Microbacia hidrográfica do córrego do Ceveiro (MHCC) possui uma área de 1990,4 ha, está situada entre as coordenadas $22^{\circ} 37^{\prime} \mathrm{S}$ e $47^{\circ} 43^{\prime} \mathrm{W}$ e $22^{\circ} 40^{\circ} \mathrm{S}$ e $47^{\circ} 47^{\prime} \mathrm{W}$ no Município de Piracicaba (SP), sendo limitada a montante pela Vila de Santana e a jusante pelo Distrito de Ártemis e pelo Rio Piracicaba. O córrego do Ceveiro é afluente do Rio Piracicaba que forma a mais importante bacia do Estado de São Paulo (Figura 1).

\subsubsection{Clima}

O clima da região, segundo Köppen, é definido como Cwa mesotérmico subtropical com inverno seco e verão chuvoso; temperatura do mês mais quente superior a $22{ }^{\circ} \mathrm{C}$ e a do mês mais frio não excede $18^{\circ} \mathrm{C}$. A distribuição de chuvas é bem marcada por um período chuvoso, de outubro a março, e um seco, de abril a setembro (Tabela 1).

O balanço hídrico dos solos da região indica a ocorrência de déficit hídrico de abril a outubro e um excesso de água entre os meses de dezembro e março. 


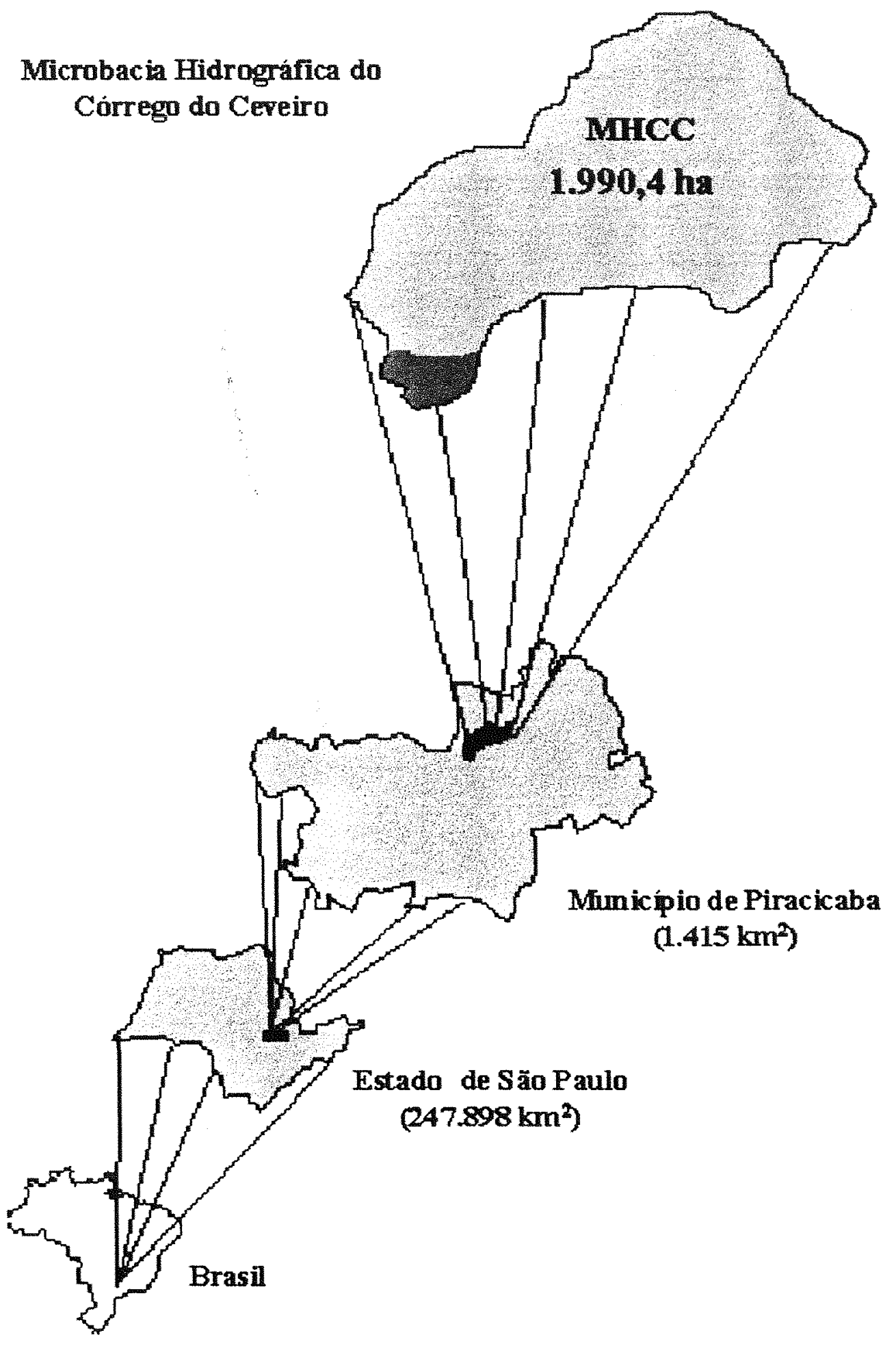

Figura 1- Localização da Microbacia Hidrográfica do Córrego do Ceveiro. 
Tabela 1- Dados climatológicos do município de Piracicaba (média de dez anos, 1986-1995). Mês Temp. Média Precipitação Evapotranspiração Precip. - Evap.

\begin{tabular}{lcccc}
\hline Janeiro & $\left({ }^{\circ} \mathbf{C}\right)$ & $(\mathbf{m m})$ & $(\mathbf{m m})$ & $(\mathbf{m m})$ \\
Fevereiro & 24,0 & 217 & 124 & 93 \\
Março & 24,7 & 183 & 107 & 76 \\
Abril & 23,9 & 136 & 114 & 22 \\
Maio & 21,0 & 65 & 79 & -14 \\
Junho & 17,6 & 52 & 68 & -16 \\
Julho & 16,8 & 46 & 60 & -14 \\
Agosto & 17,2 & 26 & 67 & -41 \\
Setembro & 18,9 & 29 & 87 & -58 \\
Outubro & 20,3 & 60 & 96 & -30 \\
Novembro & 22,2 & 108 & 125 & -17 \\
Dezembro & 22,9 & 132 & 132 & 0 \\
\hline
\end{tabular}

Fonte: Departamento de Ciências Exatas, ESALQ-USP.

\subsubsection{Relevo}

O relevo da microbacia é ondulado e a topografia caracteriza-se por apresentar morros em cotas variando entre 460 e $580 \mathrm{~m}$ de altitude. A Figura 2 mostra a declividade na MHCC. A declividade predominante nas encostas é de 5 a $15 \%$, representando $70 \%$ da área, e nos topos de 2 a 5\% com 13\% (Tabela 2). Nas várzeas e topos de alguns morros o relevo é plano com declives menores que $2 \%$, representando menos de $5 \%$ da área total. 


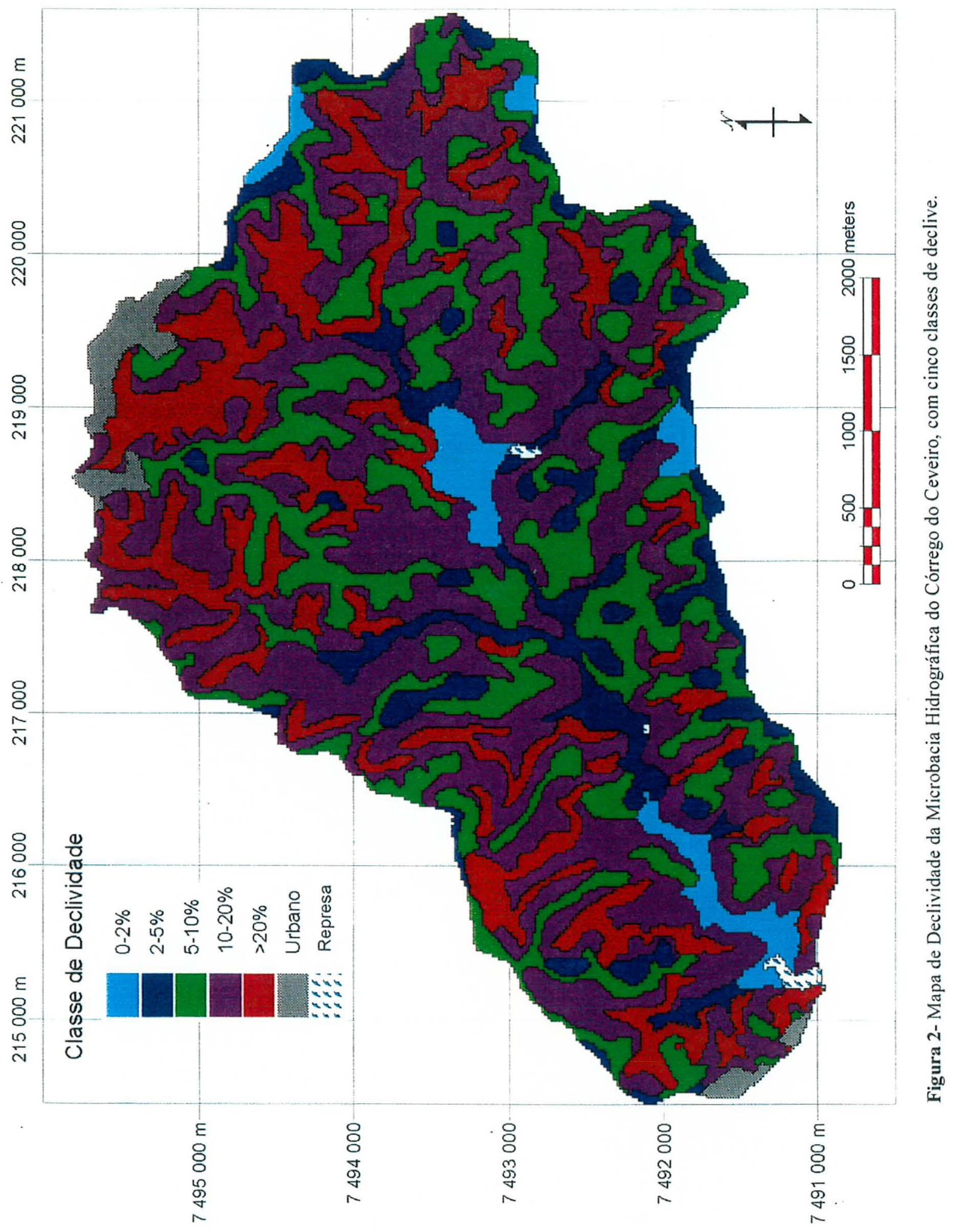


Tabela 2- Áreas totais e relativas das classes de declividade da Microbacia Hidrográfica do Córrego do Ceveiro.

\begin{tabular}{ccc}
\hline Declividade & Área total & Área relativa \\
\hline$\%$ & $($ ha) & $(\%)$ \\
$0-2$ & 83,72 & 4,2 \\
$2-5$ & 253,24 & 12,7 \\
$5-10$ & 772,44 & 38,8 \\
$10-20$ & 839,20 & 42,6 \\
$>20$ & 41,80 & 2,1 \\
\hline Total & 1990,4 & 100 \\
\hline
\end{tabular}

\subsubsection{Vegetação e Uso atual das terras}

A vegetação primária é do tipo mesófila semidecídua (floresta tropical subcaducifólia), sendo ripárias nas margens dos cursos d'água. Atualmente, alguns fragmentos são encontrados em algumas partes da rede de drenagem que compõe o Córrego do Ceveiro e nas partes mais movimentadas do relevo. O desmatamento ocorreu principalmente pelo avanço da agricultura nas últimas décadas, onde a cana-de-açúcar foi e continua sendo a principal cultura da área.

De acordo com Fiorio (1998), o qual fez uma avaliação cronológica do uso da terra e o impacto deste na microbacia (Figura 3), a cana-de-açúcar foi a cultura que apresentou maior crescimento na área, passando de 16 para $66 \%$ da área cultivada, e evidencia como causas desta expansão o Programa Proálcool e a proximidade entre a área de estudo e a usina de moagem. No período estudado (1962, 1965, 1978 e 1995), o autor constatou uma diminuição de $99 \%$ da área cultivada com cultura anual, $48 \%$ da área com pastagens e de $42 \%$ da área de reflorestamento, principalmente entre 1978 e 1995, período este que coincide com a implantação do projeto Proálcool (Tabela 3). 


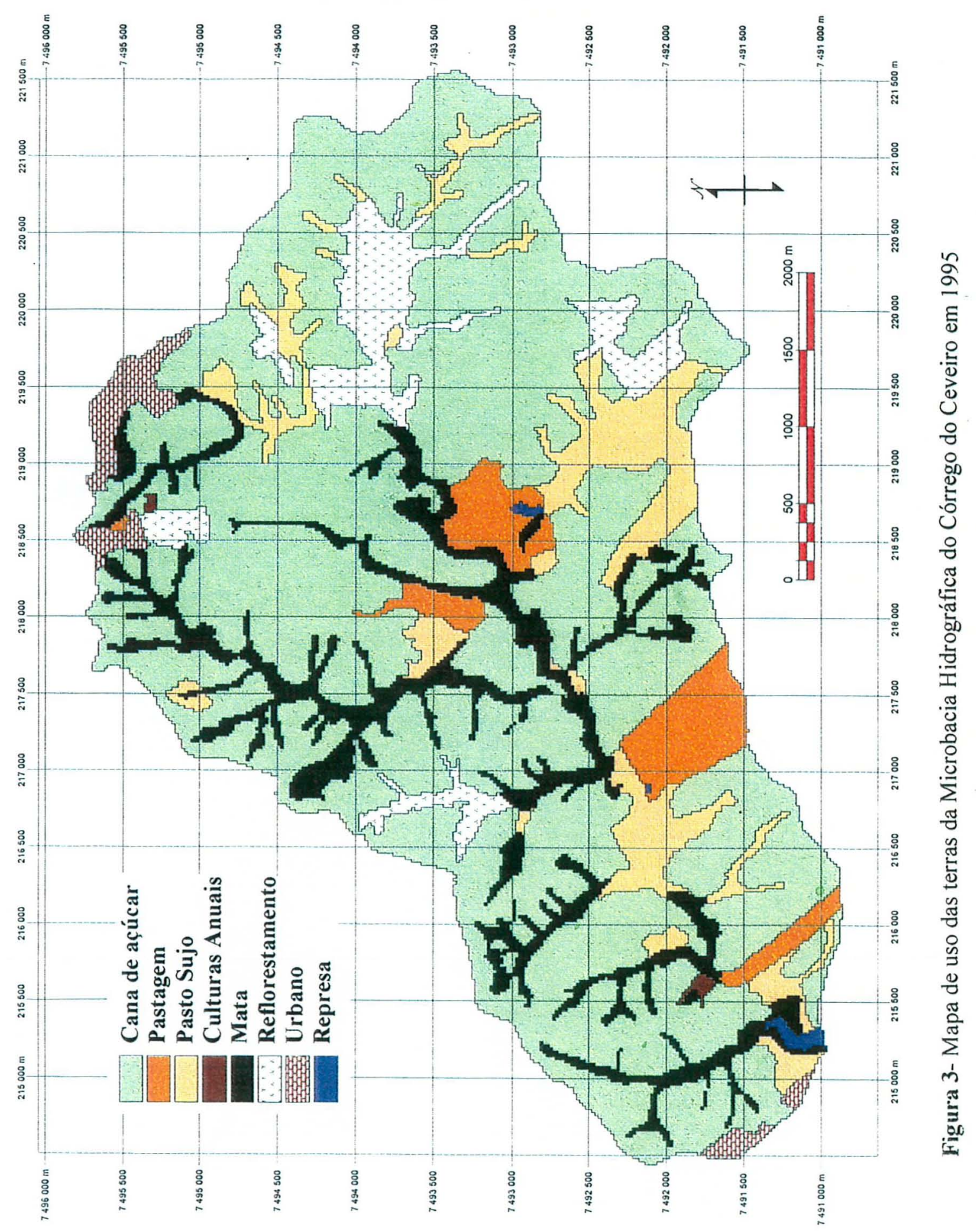


Tabela 3- Evolução cronológica do uso da terra na MHCC, para os anos de 1962, 1965, 1978 e 1995, com área total em hectares e área relativa.

\begin{tabular}{crrrrrrrrr}
\hline Uso da Terra & \multicolumn{1}{c}{$\mathbf{1 9 6 2}$} & \multicolumn{1}{c}{$\mathbf{1 9 6 5}$} & \multicolumn{1}{c}{$\mathbf{1 9 7 8}$} & \multicolumn{3}{c}{$\mathbf{1 9 9 5}$} \\
\hline & \multicolumn{1}{c}{ ha } & \multicolumn{1}{c}{$\%$} & \multicolumn{1}{c}{ ha } & \multicolumn{1}{c}{$\%$} & \multicolumn{1}{c}{ ha } & \% & \multicolumn{1}{c}{ ha } & \% \\
Cana-de-açúcar & 318,2 & 16,0 & 151,7 & 7,6 & 524,5 & 26,4 & 1317,1 & 66,2 \\
Cultura anual & 633,4 & 31,8 & 835,7 & 42,0 & 226,6 & 11,4 & 3,0 & 0,2 \\
Pastagem & 289,7 & 14,6 & 281,8 & 14,2 & 558,6 & 28,1 & 96,4 & 4,8 \\
Pasto sujo & 289,9 & 14,6 & 247,3 & 12,4 & 282,2 & 14,2 & 181,2 & 9,1 \\
Reflorestamento & 283,6 & 14,2 & 230,9 & 11,6 & 268,0 & 13,5 & 120,1 & 6,0 \\
Mata & 45,0 & 2,3 & 32,4 & 1,6 & 31,2 & 1,6 & 134,1 & 6,7 \\
Mata ciliar & 126,9 & 6,4 & 202,2 & 10,2 & 76,2 & 3,8 & 91,3 & 4,6 \\
Área urbana & 2,6 & 0,1 & 8,3 & 0,4 & 11,4 & 0,6 & 39,2 & 2,0 \\
Represas & 0 & 0,0 & 0 & 0,0 & 11,6 & 0,6 & 8,0 & 0,4 \\
\hline Total & 1990,4 & 100 & 1990,4 & 100 & 1990,4 & 100 & 1990,4 & 100 \\
\hline
\end{tabular}

Fonte: Fiorio (1998)

A área urbana teve um acréscimo de $7 \%$ de 1962 (2,6 ha) para 1995 (39,16 ha), o que pode ser devido a maior necessidade de mão-de-obra para o cultivo da cana-deaçúcar.

Outro fato importante está associado à represa do Córrego do Ceveiro, que foi projetada para fornecer água potável para o Distrito de Ártemis, ocupava cerca de 0,6 \% da área (12 ha em 1978), devido a processos erosivos, foi assoreada e passou a ocupar $0,3 \%$ da área (5,5 ha em 1995), ou seja, uma redução de $50 \%$. Hoje a represa do Córrego do Ceveiro se encontra desativada não mais fornecendo água para a vila. Entre 1978 e 1995 foram construidas 4 pequenas represas, somando 2,5 ha.

\subsubsection{Geologia e Material de origem dos solos}

A maior parte do Estado de São Paulo acha-se incluída na bacia sedimentar do Paraná, que é uma unidade geotectônica estabelecida sobre a plataforma Sul-Americana 
a partir do Devoniano Inferior, a persistente subsidência desta bacia permitiu a acumulação de grande quantidade de sedimentos. A MHCC está inserida na bacia do Paraná, e apresenta coluna estratigráfica representada por sedimentos do Grupo São Bento e Grupo Passa Dois (Instituto de Pesquisa Tecnológica, 1981).

O substrato geológico, segundo o mapa geológico do Estado de São Paulo (Instituto de Pesquisa Tecnológica, 1981) escala 1:500.000, é representado por rochas relacionadas com arenitos da Formação Pirambóia e intrusivas básicas associadas à Formação Serra Geral, ambas do Grupo São Bento e pela formação Corumbataí do Grupo Passa Dois.

A formação Pirambóia recobre a formação Corumbataí, com contato por discordância erosiva, com destruição de espessura não estimável das camadas da Formação Corumbataí (Instituto de Pesquisa Tecnológica, 1981). Na área de estudo ocorre locais onde a interface entre as duas formações é nítido devido à presença de bancos delgados de rochas de sílex, típico da formação Corumbataí, aflorando no terreno em cotas definidas. Ocorrem em alguns locais afloramentos dos sills de diabásio (Figura $4)$.

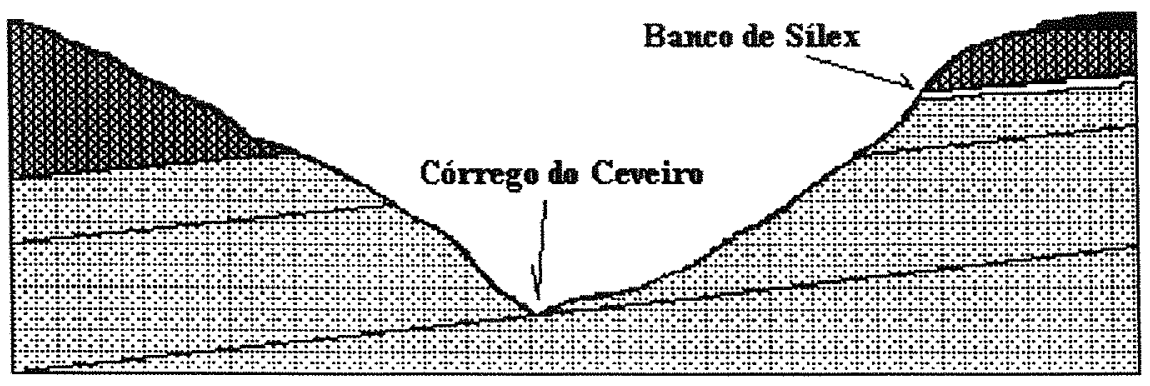
Intrusiras Básicas - Furmaça Serra Geral
Arenitos de Granulaçãe Média-Fina - Formação Pirambóia
Plilitos, Argilitos e Folhelhos - Formaça Corumbatai

Figura 4- Corte transversal da Microbacia mostrando a disposição das formações geológicas. 
A formação Pirambóia (TRJp) possui idade não definida entre o Triássico Inferior e o Jurássico, litologicamente é caracterizada por uma sucessão de camadas arenosas, incluindo arenitos finos a médios avermelhados, siltítos argilosos com estratificação plana paralela, destacada pela alternância de lâminas mais ou menos ricas em argila ou silte, podendo apresentar estratificação cruzada, de dimensões média a grande, do tipo tangencial. Níveis de folhelhos e arenitos argilosos de cores variegadas (cinzas, arroxeadas e avermelhadas) e raras intercalações de natureza argilo-arenosas podem ser encontradas (Instituto de Pesquisa Tecnológica, 1981).

A Formação Corumbataí $(\mathrm{Pc})$, pertence ao Permiano Superior, aflora continuamente até o divisor dos rios Tietê e Piracicaba para norte, até próximo de Minas Gerais, onde parece não se expor, podendo ser interrompida por sills de diabásio. É caracterizada por depósitos marinhos com estratificação plana paralela, predominam siltítos e arenitos finos em parte concrecionados por calcário e sílex, de coloração vermelha arroxeada no topo e esverdeada na base (Instituto de Pesquisa Tecnológica, 1981).

Os solos formados a partir de rochas da Formação Pirambóia encontram-se nas cotas mais elevadas do lado direito da MHCC (entende-se o sentido de observação do montante á jusante da microbacia), são representados pelos ARGISSOLOS e ALISSOLOS (Embrapa, 1999), equivalentes aos Podzólicos Vermelho-Amarelos (Embrapa, 1988) e NEOSSOLOS LITÓLICOS - Solos Litólicos - com textura arenosa a média, ocorrendo em aproximadamente $25 \%$ da área total. Cerca de $67 \%$ dos solos da área de estudo possuem a formação Corumbataí como material de origem (Sparovek, 1991), ocorrendo principalmente ás margens do Ceveiro e lado esquerdo da MHCC (sentido de observação do montante à jusante).

A Formação Serra Geral é caracterizada por intrusões básicas que recobrem a Formação Pirambóia, os solos oriundos destas intrusões ocorrem na cabeceira da MHCC do lado direito (mesmo sentido de observação) e uma pequena área no terço médio direito e são representados pelos NITOSSOLOS VERMELHOS - Terra Roxa Estruturada. 


\subsubsection{Geomorfologia}

O mapa geomorfológico foi elaborado a partir de fotos aéreas na escala 1:25.000, do ano de 1995. O mapa final foi confeccionado na escala 1:10.000, utilizando as técnicas de mapeamento propostas por Savigear (1965).

Foram mapeadas as rupturas de declividade, que é definida por Savigear (1965), como uma mudança gradativa de declive da vertente, podendo ser convexa e côncava. As rupturas convexas ou positivas são áreas de máxima energia, considerando que os solos nessas áreas possuem horizonte B textural, apresentam grande potencial para serem fontes de sedimentos no processo erosivo. As rupturas côncavas ou negativas são áreas de baixa energia, onde os sedimentos produzidos no processo erosivo tendem a ser depositados, são áreas de baixadas e planas, onde a enxurrada não tem energia suficiente para transportar os sedimentos (Figura 5).

O mapa geomorfológico consegue traduzir a realidade da área quanto à tendência do processo erosivo, através da sua interpretação é possível identificar as áreas de perda, transporte e deposição dos sedimentos.

\subsection{Levantamento Semidetalhado de Solos}

O mapa semidetalhado (Figura 6) foi obtido a partir da Carta Pedológica da Folha de Piracicaba, escala 1:100.000, quadrícula de Piracicaba, executado pelo Instituto Agronômico de Campinas (Oliveira \& Prado, 1989). Este mapa foi ampliado cartograficamente até a escala 1:10.000 e transferida as informações de solos para um mapa básico da microbacia hidrográfica do Córrego do Ceveiro. O ajuste dos mapas foi feito utilizando-se como amarração à rede de drenagem. $O$ mapa básico, com as informações de solos, foi então digitalizado manualmente de acordo com os procedimentos expostos na seção 3.4.2. 

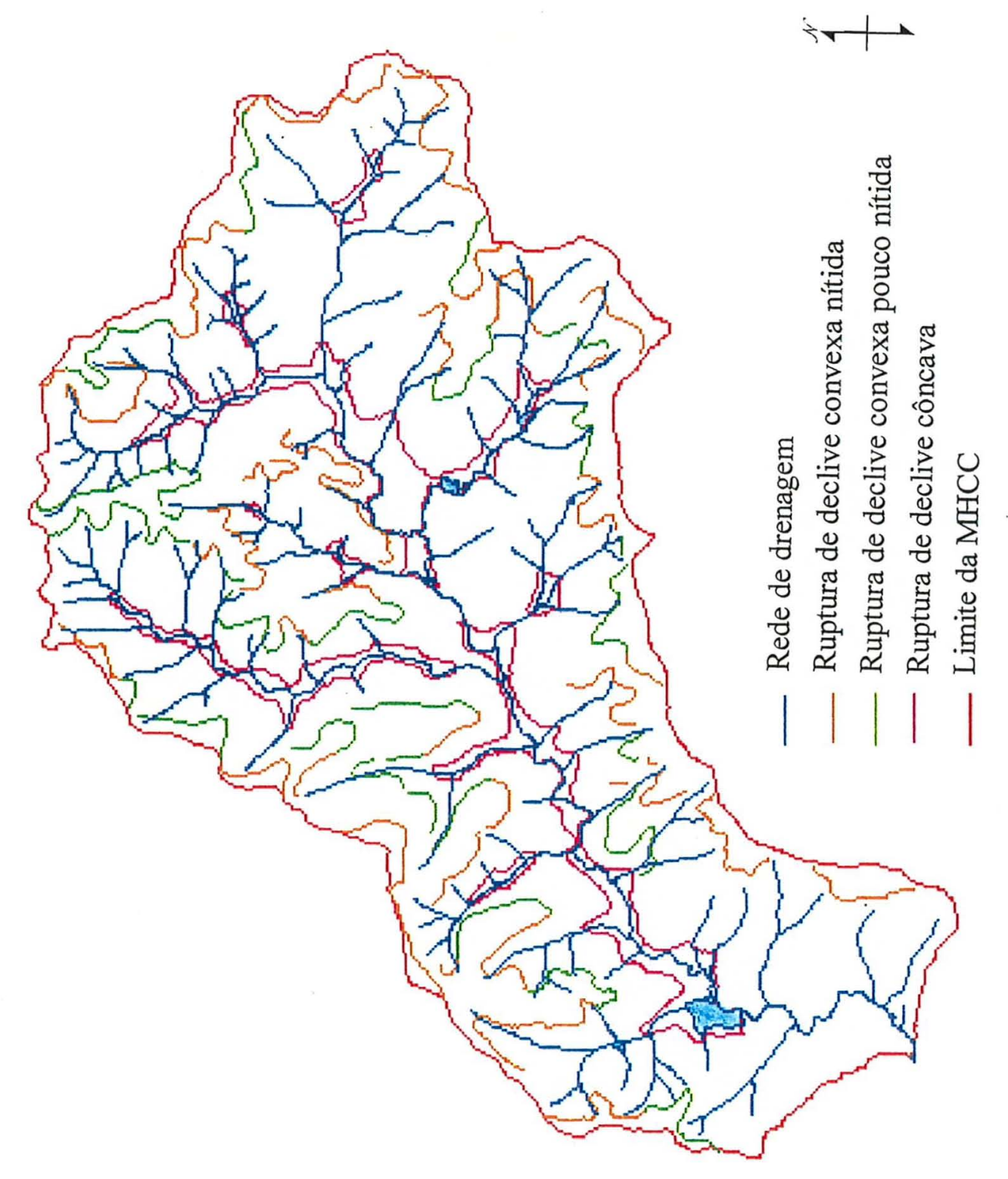


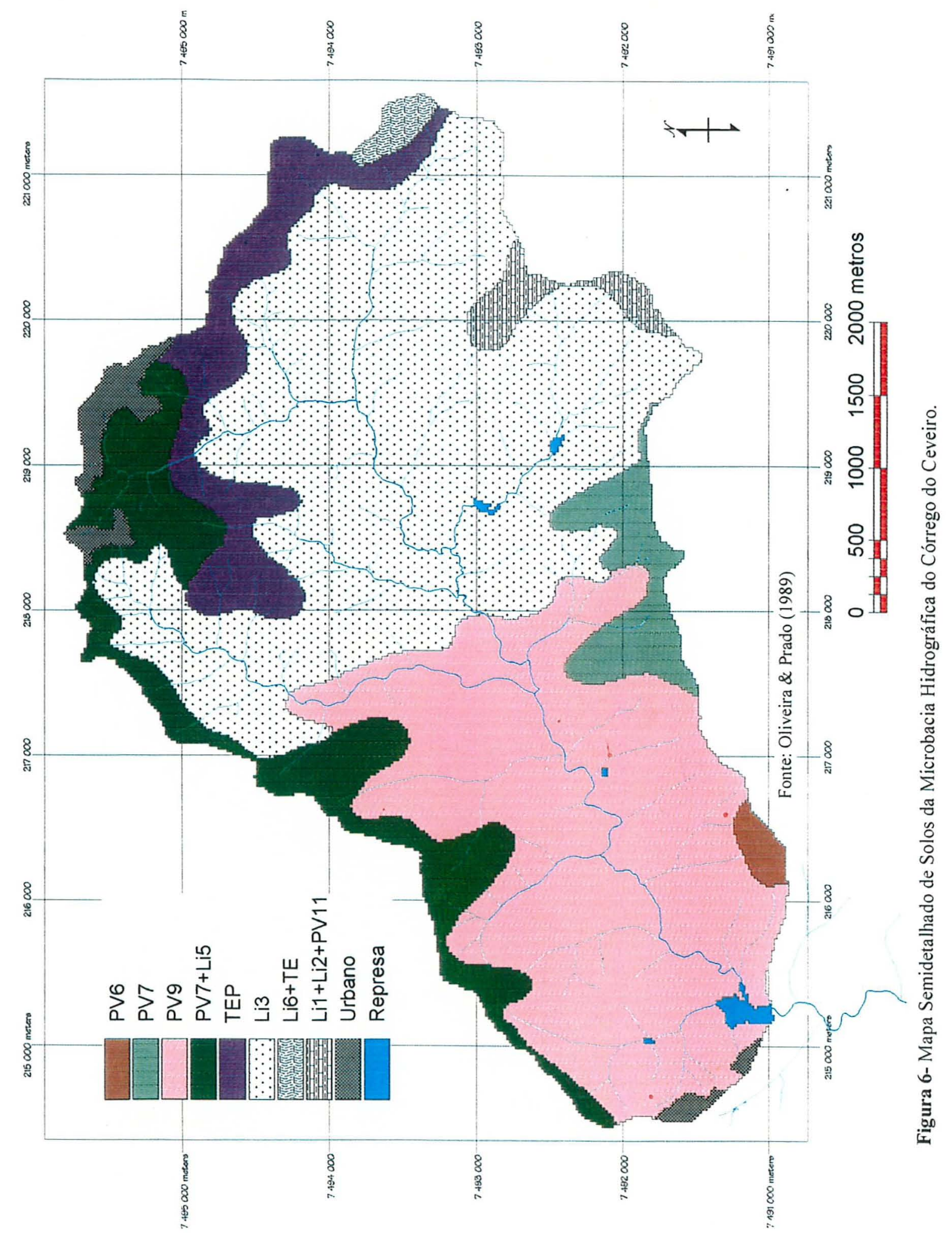


O levantamento semidetalhado identificou na área da $\mathrm{MHCC}$ oito unidades de mapeamento, ocorrendo as seguintes classes de solos: Podzólico Vermelho Amarelo (PV), Solos Litólicos (Li) e Terra Roxa Estruturada (TE e TEP). Os Solos Litólicos e os solos Podzólico Vermelho Amarelo são dominantes na área (Tabela 4), sendo que a unidade de mapeamento Li3 - representa $42 \%$ da área, enquanto a unidade PV9 Unidade Santa Cruz - ocorre em $32 \%$ da microbacia. Os Podzólicos são dominantes na Quadrícula de Piracicaba (Tabela 4).

\section{Legenda do Mapa Semidetalhado de Solos da MHCC:}

PV6 = Grupamento indiscriminado de Podzólicos Vermelho-Amarelos $\mathrm{Tb}, \mathrm{A}$ moderado, textura arenosa/média ou média. Unidade Baguari.

PV7 = Grupamento indiscriminado de Podzólicos Vermelho-Amarelos abruptos, A moderado e espesso, textura arenosa/média. Unidade Serrinha.

PV9 = Grupamento indiscriminado de Podzólicos Vermelho-Amarelos Tb abruptos, A moderado, textura arenosa/argilosa ou média/argilosa. Unidade Santa Cruz.

PV7+Li5 = Associação de Grupamento indiscriminado de Podzólicos Vermelho-Amarelos abruptos, A moderado e espesso, textura arenosa/média + Solos Litólicos Eutróficos, A moderado ou chemozêmico, substrato arenitos das Formações Botucatu ou Pirambóia.

TEP = Terra Roxa Estruturada Podzólica Eutrófica, A chernozêmico, textura média/argilosa. Unidade Santana.

Li3 = Associação de Solos Litólicos Eutróficos ou Distróficos, A moderado, proeminente ou chernozêmico, substrato sedimentos indiscriminados do Grupo Passa Dois.

Li6 + TE = Associação de Solos Litólicos Eutróficos, A moderado ou chernozêmico, substrato basalto ou diabásio. + Terra Roxa Estruturada Podzólica Eutrófica, A moderado, textura argilosa ou muito argilosa. Unidade Estruturada.

Li1 + Li2 + Associação de Solos Litólicos cascalhentos indiscriminados. + Solos Litólicos Eutróficos ou

PV11 = Distróficos, A moderado, proeminente ou chernozêmico, textura média, substrato sedimentos indiscriminados do Grupo Tubarão. + Grupamento indiscriminado Podzólicos VermelhoAmarelos com cascalho e/ou cascalhentos.

Urbano $=$ Área urbana

Represa $=$ Represa

Fonte: Carta Pedológica Semidetalhada do Estado de São Paulo (Oliveira \& Prado, 1989) - Quadrícula Piracicaba. 
Tabela 4- Área total e relativa, número de áreas (delineações) e área média das delineações das unidades de mapeamento do mapa semidetalhado de solos da MHCC (Oliveira \& Prado, 1989).

\begin{tabular}{ccccc}
\hline $\begin{array}{c}\text { Unidade de } \\
\text { Mapeamento }\end{array}$ & Área total & Área relativa & $\begin{array}{c}\text { Número de } \\
\text { áreas }\end{array}$ & Área média \\
\hline PV6 & (ha) & $\%$ & & (ha) \\
PV7 & 12.92 & 0.65 & 1 & 12,92 \\
PV9 & 71,68 & 3,60 & 1 & 71,68 \\
PV7 + Li5 & 640,24 & 32,17 & 1 & 640,24 \\
TEP & 204,52 & 10,28 & 1 & 204,52 \\
Li3 & 142,84 & 7,18 & 1 & 142,84 \\
Li6 + TE & 826,04 & 41,50 & 1 & 826,04 \\
Li1 + Li2 + PV11 & 13,48 & 0,68 & 1 & 13,48 \\
Área urbana & 31,44 & 1,58 & 2 & 15,72 \\
Represas & 39,2 & 1,97 & 4 & 9,80 \\
Total & 8,04 & 0,40 & 5 & 1,61 \\
\hline
\end{tabular}

As características químicas e granulométricas dos solos da Quadrícula de Piracicaba (algumas unidades de mapeamento), que ocorrem na MHCC, são apresentadas no Anexo C, foram elaboradas, também, algumas estatisticas básicas, tais como: Média (X), limite de confiança (t.Sx), mínimo, máximo e coeficiente de variação (CV) dessas unidades.

\subsection{Levantamento Detalhado de Solos-1991}

Foram identificados pelo Mapa Detalhado de Solos da MHCC feito em 1991 (Sparovek, 1991), escala 1:10.000, sete classes de solos: Podzólico Vermelho-Amarelo (PV), Podzólico Vermelho-Escuro (PE), Terra Roxa Estruturada (TE), Cambissolo (Cb), Solos Aluviais (A), Solos Litólicos (Li) e Hidromórficos (H). De acordo com suas especificidades de caráter físico, químico ou morfológicos, estas classes de solos foram responsáveis pela definição de trinta e uma unidades de mapeamento (Figura 7). 


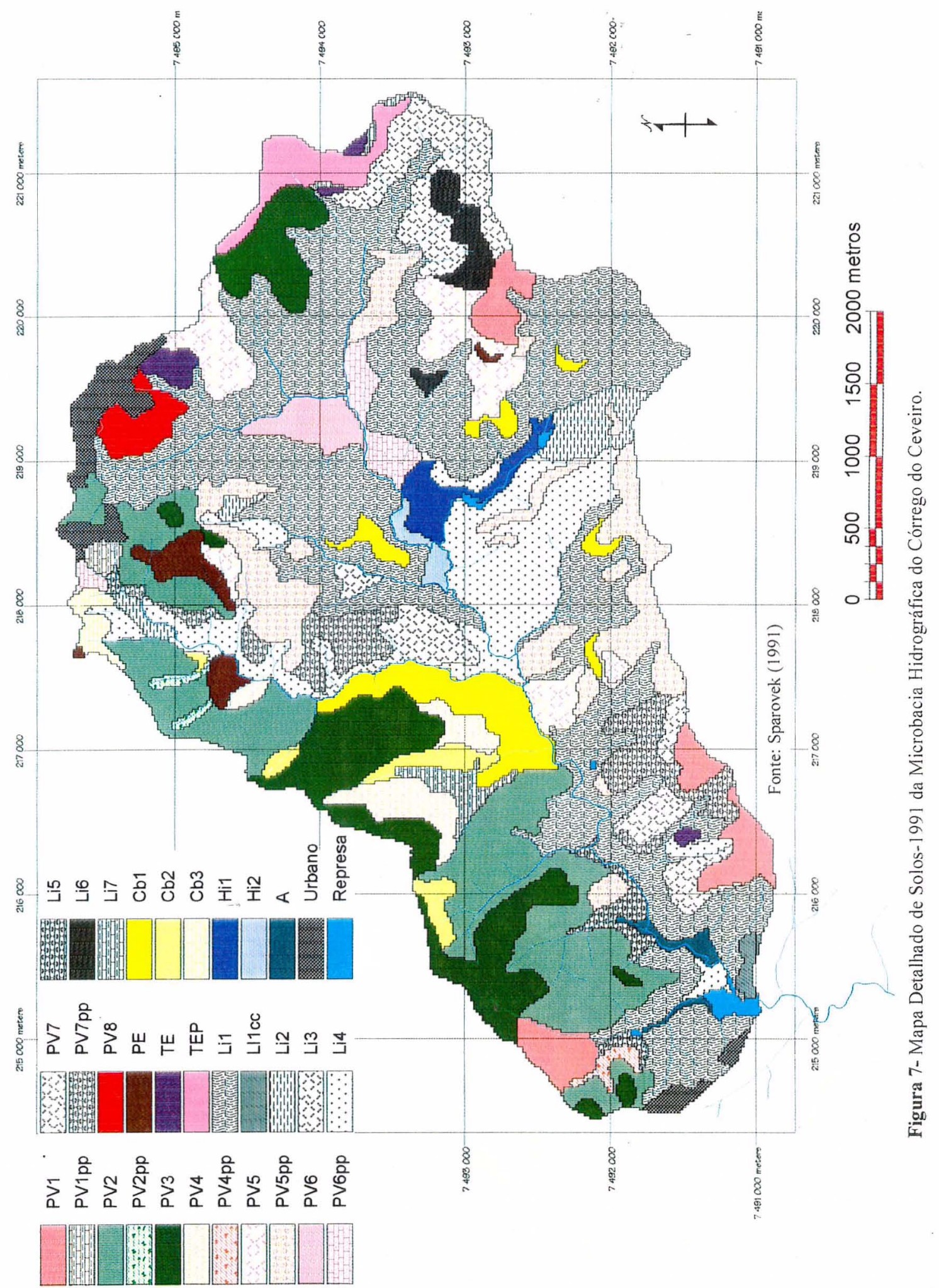




\section{Legenda do Mapa Detalhado de Solos-1991:}

PV1 = Podzólico Vermelho-Amarelo, endoálico, Tb, A moderado ou chernozêmico, textura arenosa/média.

PVI pp = Podzólico Vermelho-Amarelo, endoálico, Tb, A moderado ou chemozêmico, textura arenosa/média, fase pouco profunda.

PV2 = Podzólico Vermelho-Amarelo, álico, Ta, A moderado, textura arenosa/média.

PV2pp = Podzólico Vermelho-Amarelo, álico, Ta, A moderado, textura arenosa/média fase pouco profunda.

PV3 = Podzólico Vermelho-Amarelo, álico Ta ou $\mathrm{Tb}, \mathrm{A}$ moderado arênico, textura arenosa/média.

PV4 = Podzólico Vermelho-Amarelo, eutrófico, Tb, A moderado, textura arenosa/média.

PV4pp = Podzólico Vermelho-Amarelo, eutrófico, Tb, A moderado, textura arenosa/média fase pouco profunda.

PV5 = Podzólico Vermelho-Amarelo, eutrófico, Tb, A moderado, textura média/argilosa.

PV5pp = Podzólico Vermelho-Amarelo, eutrófico, Tb, A moderado, textura média/argilosa fase pouco profunda.

PV6 = Podzólico Vermelho-Amarelo, eutrófico, Ta, A moderado, textura média/argilosa.

PV6pp = Podzólico Vermelho-Amarelo, eutrófico, Ta, A moderado, textura média/argilosa fase pouco profunda.

PV7 = Podzólico Vermelho-Amarelo, endoálico, Tb, A moderado, textura média/argilosa.

PV7pp = Podzólico Vermelho-Amarelo, endoálico, Tb, A moderado, textura média/argilosa fase pouco profunda.

PV8 = Podzólico Vermelho-Amarelo, eutrófico, Ta ou Tb, A moderado (arênico), textura arenosa/argilosa.

PE = Grupamento indiscriminado de Podzólico Vermelho-Escuro, textura argilosa ou argilosa/muito argilosa com ou sem cascalho (Unidade Campestre).

TE = Terra Roxa Estruturada, eutrófica, Tb, A moderado, textura argilosa (Unidade Estruturada).

TEP = Terra Roxa Estruturada Podzólica eutrófica, Tb, A moderado, textura média/argilosa (Unidade Santana).

Cb1 = Cambissolo, eutrófico ou distrófico, $\mathrm{Ta}$ ou $\mathrm{Tb}, \mathrm{A}$ moderado, textura argilosa.

Cb2 = Cambissolo, álico, Ta, A moderado, textura média.

Cb3 = Cambissolo, eutrófico, Ta, A moderado, textura média.

Li 1 = Solo Litólico, eutrófico, Ta ou Tb, A moderado ou chernozêmico, textura média, substrato siltítos da Formação. Corumbatai.

Lilcc $=$ Solo Litólico, eutrófico, Ta ou Tb, A moderado ou chernozêmico, textura média, com cascalhos, substrato siltítos da Formação Corumbataí.

Li 2 - Solo Litólico, álico, Ta A moderado, textura média, substrato siltitos da Formação Corumbataí.

Li 3 = Solo Litólico, eutrófico, Ta ou Tb, A moderado ou chernozêmico, textura argilosa, substrato folhelho da Formação. Corumbatai.

Li 4 = Solo Litólico, álico, Ta, A moderado, textura argilosa, substrato folhelho da Formação Corumbataí.

Li 5 = Solo Litólico, distrófico, Tb, A moderado, textura média, substrato arenitos da Formação Pirambóia.

Li 6 = Complexo Li3 + PV5+Cb2.

$\mathrm{Li} 7$ = Solos Litólicos substrato diabásio + Cambissolo + TEpp todos eutróficos, Tb, A moderado, textura argilosa.

A = Grupamento indiscriminado de solos aluviais.

Hi 1 = Solo Hidromórfico, álico, Ta, A moderado, textura arenosa/média.

Hi 2 = Solo Hidromórfico, eutrófico, $\mathrm{Tb}, \mathrm{A}$ moderado, textura média/argilosa.

Urbano Área urbana

Represa Represa

Fonte: Sparovek (1991). 
O mapa detalhado de solos-1991 identificou a dominância dos Solos Litólicos (Li) ocupando $45 \%$ da área, enquanto os Podzólicos Vermelho-Amarelos (PV) cobrem $42 \%$ da microbacia (Tabela 5). A unidade de mapeamento de maior ocorrência é a Li1 Solo Litólico, eutrófico, Ta ou $\mathrm{Tb}$, A moderado ou chernozêmico, textura média, substrato siltitos da Formação Corumbataí, que ocupa $29 \%$ da área total. No Anexo B são apresentados os resultados médios das análises químicas e granulométricas.

Tabela 5- Área total e relativa, número de áreas e área média das delineações das unidades de mapeamento de solos do mapa detalhado-1991

\begin{tabular}{ccccc}
\hline $\begin{array}{c}\text { Unidade de } \\
\text { Mapeamento }\end{array}$ & Área total (ha) & Área relativa \% & $\begin{array}{c}\text { Número de } \\
\text { áreas }\end{array}$ & Área média (ha) \\
\hline PV1 & 59,36 & 2,98 & 4 & 14,84 \\
PV1pp & 4,84 & 0,24 & 1 & 4,84 \\
PV2 & 222,28 & 11,17 & 5 & 44,46 \\
PV2pp & 4,64 & 0,23 & 2 & 2,32 \\
PV3 & 157,00 & 7,89 & 8 & 19,63 \\
PV4 & 35,04 & 1,76 & 3 & 11,68 \\
PV4pp & 5,32 & 0,27 & 1 & 5,32 \\
PV5 & 77,56 & 3,90 & 5 & 15,51 \\
PV5pp & 125,12 & 6,29 & 13 & 9,62 \\
PV6 & 20,44 & 1,03 & 1 & 20,44 \\
PV6pp & 23,00 & 1,16 & 2 & 11,50 \\
PV7 & 27,80 & 1,40 & 3 & 9,27 \\
PV7pp & 60,64 & 3,05 & 6 & 10,11 \\
PV8 & 18,36 & 0,92 & 1 & 18,36 \\
PE & 22,80 & 1,15 & 4 & 5,70 \\
TE & 11,68 & 0,59 & 4 & 2,92 \\
TEP & 29,88 & 1,50 & 1 & 29,88 \\
Cb1 & 64,88 & 3,26 & 7 & 81,90 \\
Cb2 & 22,80 & 1,15 & 1 & 5,08 \\
Cb3 & 9,48 & 0,48 & 3 & 10,33 \\
Li 1 & 573,28 & 28,80 & 3 & 31,13 \\
Li 1cc & 5,08 & 0,26 & 7 & 20,36 \\
Li 2 & 31,00 & 1,56 & 3 & 6,21 \\
Li 3 & 93,40 & 4,69 & 2 & 10,42 \\
Li 4 & 142,52 & 7,16 & 5 & 3,27 \\
Li 5 & 18,64 & 0,94 & 7 & 9,27 \\
Li 6 & 20,84 & 1,05 & 4 & 5,70 \\
Li 7 & 16,36 & 0,82 & 1 & 9,48 \\
Hi 1 & 21,96 & 1,10 & 1 & 21,96 \\
Hi 2 & 8,40 & 0,42 & 1 & 8,40 \\
A & 8,76 & 0,44 & 2 & 4,38 \\
Area rbana & 39,20 & 1,97 & 4 & 9,80 \\
Represas & 8,04 & 0,40 & 5 & 1,61 \\
Total Solos & 1990,40 & 100,00 & 111 & 17,51 \\
\hline & & & & \\
\hline & & 13 & 13 & \\
\hline
\end{tabular}




\subsection{Levantamento Detalhado de Solos-2000}

Os solos da microbacia hidrográfica do Córrego do Ceveiro foram inicialmente identificados através do levantamento semidetalhado do Estado de São Paulo - folha Piracicaba - na escala 1:100.000, publicado em 1989 pelo IAC (Oliveira \& Prado, 1989) - identificado no presente trabalho como mapa semidetalhado de solos. Em 1991 foi realizado na área um levantamento detalhado de solos, na escala 1:10.000, com legenda de identificação de solos baseado nas normas em vigor na época (Embrapa, 1988), este levantamento foi identificado no presente trabalho como mapa detalhado de solos-1991. Posteriormente, a partir de 1997 e encerrado em 2000, um novo levantamento detalhado de solos da área foi executado como subsídio para o desenvolvimento desta tese. Este levantamento de solos, identificado no presente trabalho como mapa detalhado de solos2000 , inicialmente teve sua legenda de solos baseado nas normas anteriormente em vigor para classificação de solos no Brasil (Embrapa, 1988), em julho de 1999 com a edição do Sistema Brasileiro de Classificação de Solos (Embrapa, 1999) os solos foram enquadrados no novo sistema e foi feita uma nova legenda para o mapa detalhado de solos-2000.

\subsubsection{Materiais cartográficos básicos}

A carta planialtimétrica da MHCC na escala 1:10.000 foi gerada a partir de quatro cartas planialtimétricas, com curvas de nível eqüidistantes em $5 \mathrm{~m}$, na escala 1:10.000 do Plano Cartográfico do Estado de São Paulo, cujo levantamento foi realizado pela Terrafoto, junto ao Governo do Estado de São Paulo e Secretaria de Economia e Planejamento.

- Folha da Estância Lago Azul (SF23-Y-A-IV-1-SE-B), articulação 070/087;

- Folha de Ártemis (SF23-Y-A-IV-1-SE-D), articulação 071/087;

- Folha do Córrego das Ondas (SF23-Y-A-IV-2-SO-A), articulação 070/088;

- Folha da Vila Olímpia (SF23-Y-A-IV-2-NO-E), articulação 069/088.

Foram utilizadas fotografias aéreas pancromáticas verticais dos anos de: 
- 1962, na escala nominal aproximada de 1:25.000 do vôo junto ao IAC.

- 1965, na escala nominal aproximada de 1:60.000 do vôo junto a USAF-AST 10.

- 1978, na escala nominal aproximada de 1: 35.000 do vôo junto a Terrafoto/IGC.

- 1995, na escala nominal aproximada de 1:25.000 do vôo junto a BASE.

\subsubsection{Mapas digitais básicos}

A partir das cartas planialtimétricas, foi possível confeccionar um mapa planialtimétrico básico da microbacia hidrográfica do Córrego do Ceveiro. O mapa básico deu origem a três planos de informação - contorno da bacia, curvas de nível e hidrografia, os quais foram digitalizados utilizando o programa gráfico AUTOCAD 12 (versão DOS). Os arquivos digitais, formato.$d x f$ foram exportados para o Sistema de Informação Geográfica (IDRISI for Windows, versão 2.0, Eastman, 1997) e logo depois reexportados para o SIG TNT MIPs. A digitalização dos demais mapas: Mapa Geomorfológico; Mapa Semidetalhado de Solos (Oliveira \& Prado, 1989); Mapa Detalhado-1991 (Sparovek, 1991); e Mapa Detalhado-2000; seguiram as mesmas etapas. Dessa maneira todas as informações cartográficas geradas neste trabalho foram sobrepostas e se encontram georeferenciadas

Nos arquivos da MHCC, foi usada a projeção métrica Universal Transversa de Mercator ou coordenadas UTM (Zona 23 Sul, Datum SA 1969 Brasil, IUGG 1967).

\subsubsection{Amostragem de Solos}

A primeira fase dos trabalhos consistiu na definição dos pontos de checagem de solos, tendo como base a fotointerpretação realizada, o mapa semidetalhado (Oliveira \& Prado, 1989 e o mapa detalhado-1991 (Sparovek, 1991), já existentes. Com este objetivo, percorreu-se toda a área, definindo-se as estratégias para execução dos trabalhos. $\mathrm{Na}$ execução dessa etapa, registraram-se características morfológicas importantes às conceituações das classes de solos e fases empregadas, e os dados referentes ao regime hídrico, relevo e vegetação da área de estudo. 
A segunda fase dos trabalhos consistiu na checagem de campo. Esta etapa foi executada através de caminhamento no campo, através de tradagens realizadas previamente à abertura das trincheiras, para verificação da homogeneidade da unidade.

Foram coletadas amostras deformadas e indeformadas, por tradagem e em trincheira, para caracterização física, química e morfológica.

Nas coletas efetuadas com o trado, os solos foram amostrados até $120 \mathrm{~cm}$, profundidade normalmente suficiente, na microbacia, para se atingir o horizonte $\mathrm{C}$ ou $\mathrm{R}$, nas profundidades 0 a $20 \mathrm{~cm}, 20$ a $40 \mathrm{~cm}, 40$ a $60 \mathrm{~cm}, 60$ a $80 \mathrm{~cm}, 80$ a $100 \mathrm{~cm}, 100$ a $120 \mathrm{~cm}$. Em alguns locais, foram efetuadas tradagens profundas para definição da espessura dos horizontes $(\mathrm{A}+\mathrm{B})$ de solos mais profundos do que $120 \mathrm{~cm}$.

Foram abertos, descritos e coletados 133 pontos espalhados por toda a área da bacia, 59 pontos espaçados regularmente em uma malha ou "grid" de aproximadamente $20 \times 20$ metros e em torno do "grid", em uma sub-bacia, foram amostrados mais 30 pontos, distribuídos ao acaso, totalizando 222 pontos amostrados por tradagem em toda a microbacia hidrográfica do Córrego do Ceveiro.

Foram abertas 30 trincheiras para caracterização dos perfis de solo em locais previamente escolhidos, de acordo com a representatividade dos solos da área que se pretendia definir. Quando o horizonte $C, C R$ ou $R$ não foi atingido até $120 \mathrm{~cm}$, foi tradado o fundo da trincheira, para definição da espessura dos horizontes $(A+B) e$ profundidade da rocha. Os solos foram descritos e as amostras coletadas por horizontes pedogenéticos. Nas trincheiras, também foram coletadas amostras indeformadas, nas profundidades de $10 \mathrm{~cm}, 30 \mathrm{~cm}, 50 \mathrm{~cm}, 70 \mathrm{~cm}, 90 \mathrm{~cm}$ e $110 \mathrm{~cm}$, com três repetições, para determinação da densidade do solo. Foram utilizados anéis do tipo Kopeck, com volume aproximado de $100 \mathrm{ml}$, retirados com amostrador do tipo Uhland.

Ao todo, somando tradagens e trincheiras, foram amostrados 252 pontos em toda a bacia. A Figura 8 mostra os locais de amostragem na microbacia e a Figura 9 detalha os pontos amostrados no "grid" e na sub-bacia em torno do "grid". 


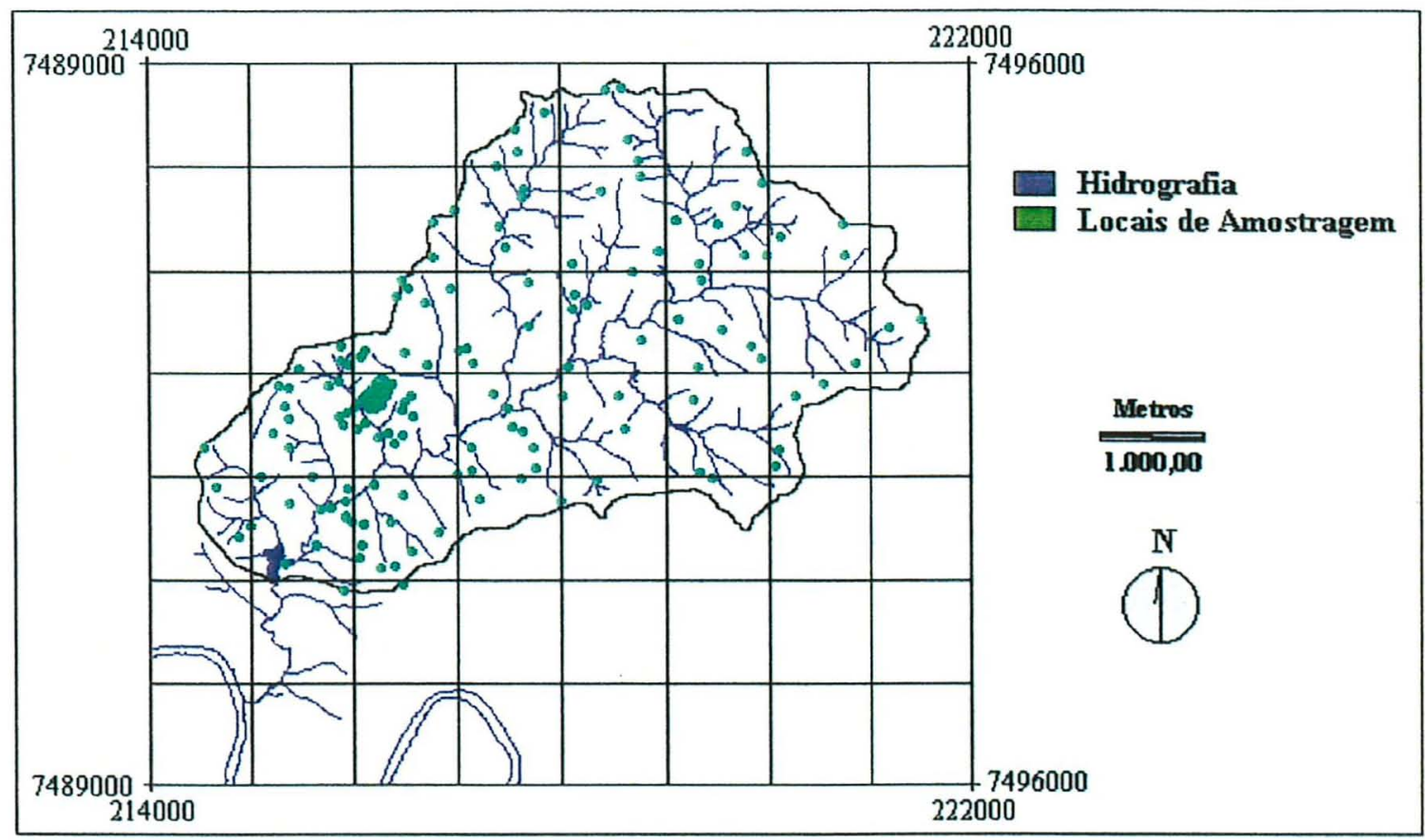

Figura 8-Locais de amostragem dos solos da Microbacia Hidrográfica do Córrego Ceveiro.

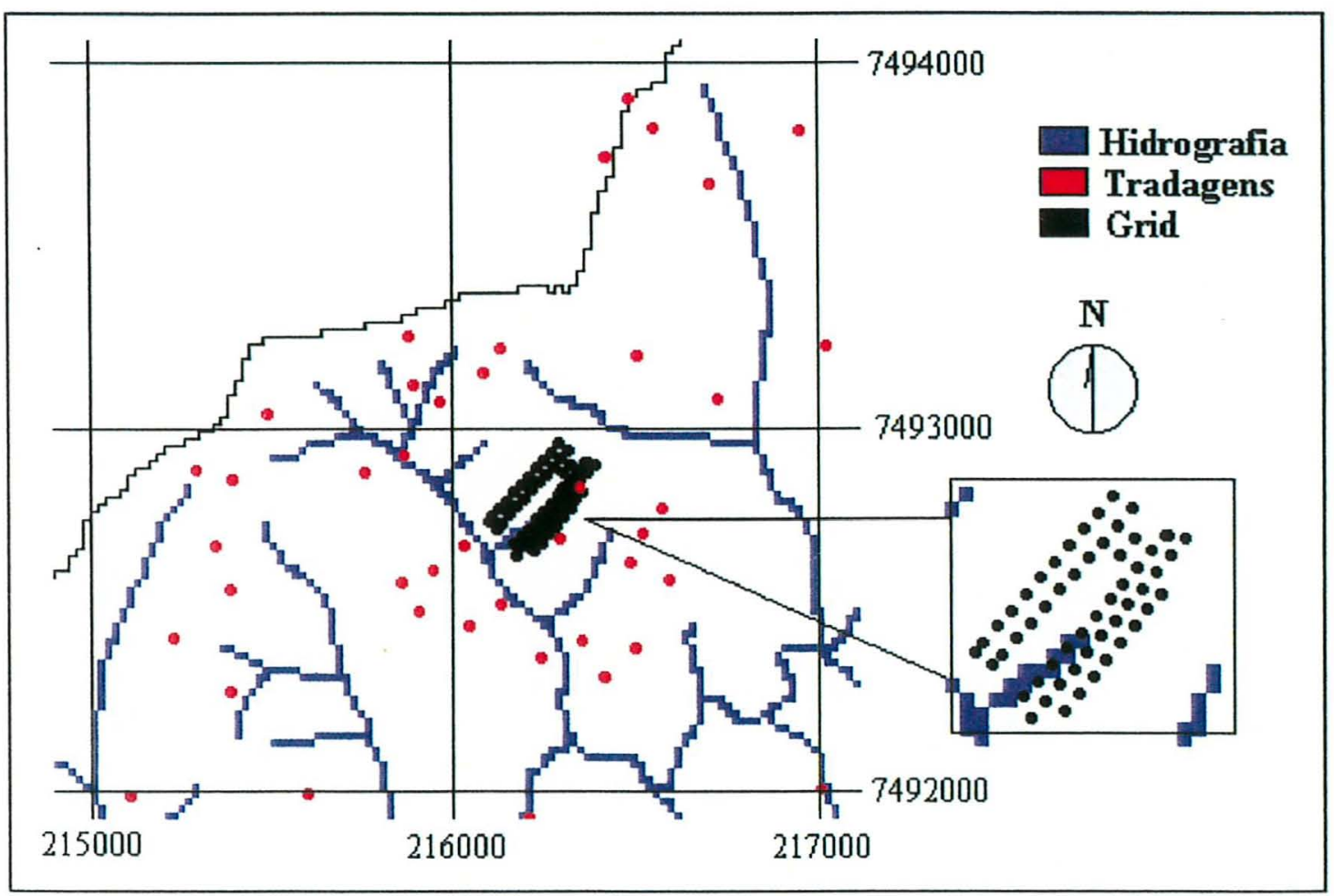

Figura 9- Detalhe da malha regular de amostragem de solos da Microbacia Hidrográfica do Córrego do Ceveiro. 
Os solos foram descritos conforme Lemos \& Santos (1996) e classificados de acordo com as normas adotadas pelo Centro Nacional de Pesquisa de Solos da Embrapa (Embrapa, 1988), e posteriormente correlacionados com o Sistema Brasileiro de Classificação de Solos (Embrapa, 1999).

\subsubsection{Georeferenciamento da Amostragem de Solos}

Os 252 perfis amostrados foram georeferenciados utilizando-se o GPS ou Global Positioning System. Foram utilizados dois equipamentos manuais, modelo Geo Explorer II, da Trimble. Um equipamento funcionou como estação base e o outro equipamento, móvel, foi levado ao campo para tomada das posições dos pontos de amostragem. Os pontos armazenados no campo foram posteriormente corrigidos no escritório, em relação à estação base, através do programa Pathfinder Office da Trimble, que faz a correção diferencial dos dados, tornando os erros de localização, que seriam de até $100 \mathrm{~m}$ sem correção, menores que $5 \mathrm{~m}$. A amostragem do "grid" foi georeferenciada com a utilização do equipamento modelo Pro $X R$ da Trible, que permite erros menores que $1 \mathrm{~m}$.

\subsubsection{Métodos Analíticos}

As amostras de solo foram analisadas no Laboratório de Física do Solo e no Laboratório de Química e Fertilidade do Solo, ambos do Departamento de Solos e Nutrição de Plantas da ESALQ/ USP.

Para execução das análises, as amostras de solo foram secas ao ar e passadas por peneira com malha de $2 \mathrm{~mm}$, obtendo-se a terra fina seca ao ar (TFSA). Nas amostras de TFSA foram realizadas as seguintes determinações: $\mathrm{pH}\left(\mathrm{em} \mathrm{H}_{2} \mathrm{O}\right.$, em KCl $1 \mathrm{~mol} \mathrm{~L}^{-1} \mathrm{e}$ em $\mathrm{CaCl}_{2} 0,01 \mathrm{~mol} \mathrm{~L}^{-1}$ ), teor de matéria orgânica ( $\mathrm{MO} \mathrm{em} \mathrm{g} \mathrm{kg}^{-1}$ ) oxidada por dicromato de sódio em $\mathrm{H}_{2} \mathrm{SO}_{4}$ e quantificada por colorimetria; fósforo disponível ( $\mathrm{P}$, $\mathrm{em} \mathrm{mg} \mathrm{kg}^{-1}$ ) e teores trocáveis de $\mathrm{K}^{+}, \mathrm{Ca}^{2+}$, e $\mathrm{Mg}^{2+}$ (em mmolc $\mathrm{kg}^{-1}$ ) extraídos pela resina de troca iônica, sendo o $\mathrm{P}$ quantificado por colorimetria e $\mathrm{K}, \mathrm{Ca}$ e $\mathrm{Mg}$, por espectrofotometria de absorção atômica; teor trocável de $\mathrm{Al}^{3+}$ ( $\mathrm{Al} \mathrm{em} \mathrm{mmolc} \mathrm{kg}{ }^{-1}$ ), extraído por $\mathrm{KCl} 1 \mathrm{~mol} \mathrm{~L}^{-1}$ 
e determinado por titulação ácido-base; $\mathrm{H}^{+}+\mathrm{Al}^{3+}$ método do tampão SMP. Foram também calculados a capacidade de troca de cátions (CTC em mmolc $\mathrm{kg}^{-1}$ ), atividade da argila (Targ em mmolc $\mathrm{kg}^{-1}$ argila), saturação por bases (V\%, em \%) e saturação por alumínio (m, em \%). Os métodos analíticos seguiram os procedimentos descritos por Raij et al. (1987). A análise granulométrica foi feita após dispersão da amostra com Calgon e Hidróxido de Sódio utilizando o densímetro de Boyoucus, as areias foram subdividas, através de tamisagem, em cinco classes: areia muito grossa $(2,0-1,0 \mathrm{~mm})$, areia grossa $(1,0-0,5 \mathrm{~mm})$, areia média $(0,5-0,25 \mathrm{~mm})$; areia fina $(0,25-0,10 \mathrm{~mm})$, areia muito fina $(0,10-0,05 \mathrm{~mm})$, conforme descrito por Camargo et al. (1986). Resultados apresentados no Anexo A.

\subsubsection{Critérios, definições e conceitos para estabelecimento das classes de solos e fases empregadas}

O mapeamento original do mapa detalhado de solos-2000 foi feito com base nos conceitos da antiga classificação de solos utilizada pela Embrapa (Embrapa, 1988). Posteriormente a legenda de solos foi atualizada com as normas definidas pelo Sistema Brasileiro de Classificação de Solos (Embrapa, 1999).

Para a subdivisão das classes de solos em níveis categóricos mais baixos, e sempre que apropriado, utilizaram-se os seguintes termos:

- Profundidade do solo: Foi utilizado para subdividir os Solos com horizonte B textural (ALISSOLOS CRÔMICOS, ARGISSOLOS VERMELHOAMARELOS e LUVISSOLOS CRÔMICOS) antigo Podzólico Vermelho Amarelo em lépticos (pouco profundo) e profundos, sendo usado o termo I nas classes dos lépticos - condições de solos nos quais o contato lítico (horizonte R) ou para-lítico (horizonte CR) ocorre entre 50 e $100 \mathrm{~cm}$ de profundidade. Apresentado na legenda do mapa como I.

- Arênico: caráter utilizado nos solos com horizonte B textural como atributo para separação de unidades taxonômicas; consiste em solos com horizonte $A+E$, 
arenosos com espessura superior a $50 \mathrm{~cm}$, podendo atingir até $100 \mathrm{~cm}$ de espessura. Apresentado na legenda do mapa como q.

- Erodida: fase utilizada para identificar alguns ALISSOLOS CRÔMICOS e ARGISSOLOS VERMELHO-AMARELOS que apresentavam ausência, total ou parcial, do horizonte A devido à erosão.

- Mudanca textural abrupta: Consiste em um considerável aumento no conteúdo de argila dentro de pequena distância na zona de transição entre o horizonte $\mathrm{A}$ ou E e o horizonte subjacente $B$.

- Atividade da Argila: conforme capacidade de permuta de cátions (T) no horizonte $\mathrm{B}$ ou no horizonte $\mathrm{C}$, se não existir $\mathrm{B}$, e $\mathrm{A}$, se não existir $\mathrm{B}$ nem $\mathrm{C}$. No Sistema Brasileiro de Classificação de Solos (Embrapa, 1999) o solo Ta apresenta valor igual ou superior a 270 mmolc kg-1 de argila e $\mathrm{Tb}$, valor inferior a esse, sem correção para carbono.

- Eutrofismo e Distrofismo: conforme saturação de bases (V\%) do horizonte B, do horizonte $\mathrm{C}$ se não existir $\mathrm{B}$, ou do horizonte $\mathrm{A}$ se não existir $\mathrm{B}$ nem $\mathrm{C}$. Eutrófico (e) $-\mathrm{V} \%>50 \%$ e Distrófico (d) - V\% $<50 \%$.

- Epidistrófico: indica que solos eutróficos ou álicos são superficialmente distróficos.

- Epieutrófico: indica que solos distróficos ou álicos são superficialmente eutróficos.

- Álico (a): conforme saturação efetiva de alumínio trocável superior a 50\% no horizonte $\mathrm{B}$, no horizonte $\mathrm{C}$ se não existir $\mathrm{B}$, ou do horizonte $\mathrm{A}$ se não existir B nem C.

- Epiálico: indica que solos distróficos ou eutróficos são superficialmente álicos.

- Alumínico: indica teor extraível de alumínio $\geq 40 \mathrm{mmolc} / \mathrm{kg}$, além de apresentar saturação por alumínio $>50 \%$ e/ou saturação por bases $<50 \%$ no horizonte $\mathrm{B}$.

- Tipos de Horizontes A: 
a) Horizonte A Moderado - Horizonte A que apresenta teores de carbono orgânico superior a $0,58 \%$ nos solos de textura muito argilosa, média e siltosa, (admite-se teores de carbono orgânico inferiores a $0,58 \%$ nos solos de textura arenosa) não satisfazendo qualquer uma das exigências de cor, espessura, saturação de bases (V\%) e teor de $\mathrm{P}_{2} \mathrm{O}_{5}$ que caracterizam um $\mathrm{A}$ chernozêmico, proeminente ou antrópico.

b) Horizonte A Fraco - Horizonte A que apresenta teores de carbono orgânico igual ou inferior a $0,58 \%$, cores muito claras e valores superiores a 5,5 quando seco. Não apresenta desenvolvimento de estrutura, ou apresenta estrutura fracamente desenvolvida, ou é maciço e duro ou muito duro quando seco.

c) Horizonte A Chernozêmico - Horizonte mineral, relativamente espesso, de cor escura, $\mathrm{V} \%>50$ e estrutura desenvolvida.

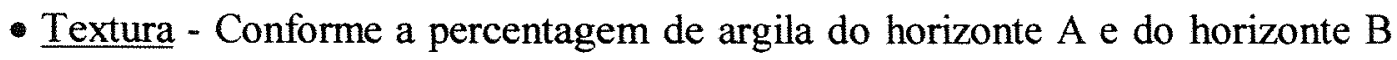
ou C, caso não exista horizonte B.

textura arenosa $-<$ de $150 \mathrm{~g}$ de argila $\mathrm{kg}^{-1}$ TFSA e dentro das classes texturais areia e areia franca

textura média - 150 a $350 \mathrm{~g}$ de argila $\mathrm{kg}^{-1}$ TFSA

textura argilosa - 350 a $600 \mathrm{~g}$ de argila $\mathrm{kg}^{-1}$ TFSA

textura muito argilosa - mais de $600 \mathrm{~g}$ de argila $\mathrm{kg}^{-1}$ TFSA

- Pedregosidade e Rochosidade - A pedregosidade refere-se à presença de calhaus e matacões (constituídos, ou não, de concreções) na massa do solo e/ou na superfície do mesmo que impedem a utilização de máquinas e implementos agrícolas. A rochosidade relaciona-se à exposição de substrato rochoso ou "boulders" com diâmetro médio maior que $100 \mathrm{~cm}$ na superficie ou na massa do solo e que impedem o uso de máquinas agrícolas.

- Caráter gleico: indica a presença de características de gleização em alguns ARGISSOLOS AMARELOS associados a GLEISSOLOS HÁPLICOS. 


\subsection{Comparação e qualidade dos mapas de solos}

A comparação e qualidade dos mapas de solos foi determinada utilizando critérios pedológicos e cartográficos. A qualidade pedológica depende, em geral, do tipo de levantamento de solos; nível categórico utilizado para identificação das unidades taxonômicas; escala de mapeamento de campo e de publicação; tipos de unidades de mapeamento e seus componentes; métodos de prospecção, amostragem e verificação de limites, os quais refletem a acurácia e a precisão da informação presente nos mapas. A qualidade cartográfica depende da natureza do material básico utilizado; escala do mapa planialtimétrico, e eqüidistância das curvas de níveis; mecanismos de transposição das unidades identificadas no campo para o mapa; e área mínima mapeável, os quais refletem a facilidade de leitura do mapa. Além da acurácia, precisão e facilidade de leitura, os mapas foram comparados pela concordância entre eles. A comparação e avaliação da qualidade dos mapas de solos foi elaborada segundo adaptação do diagrama de Marsman \& Gruijter (1986) (Figura 10).

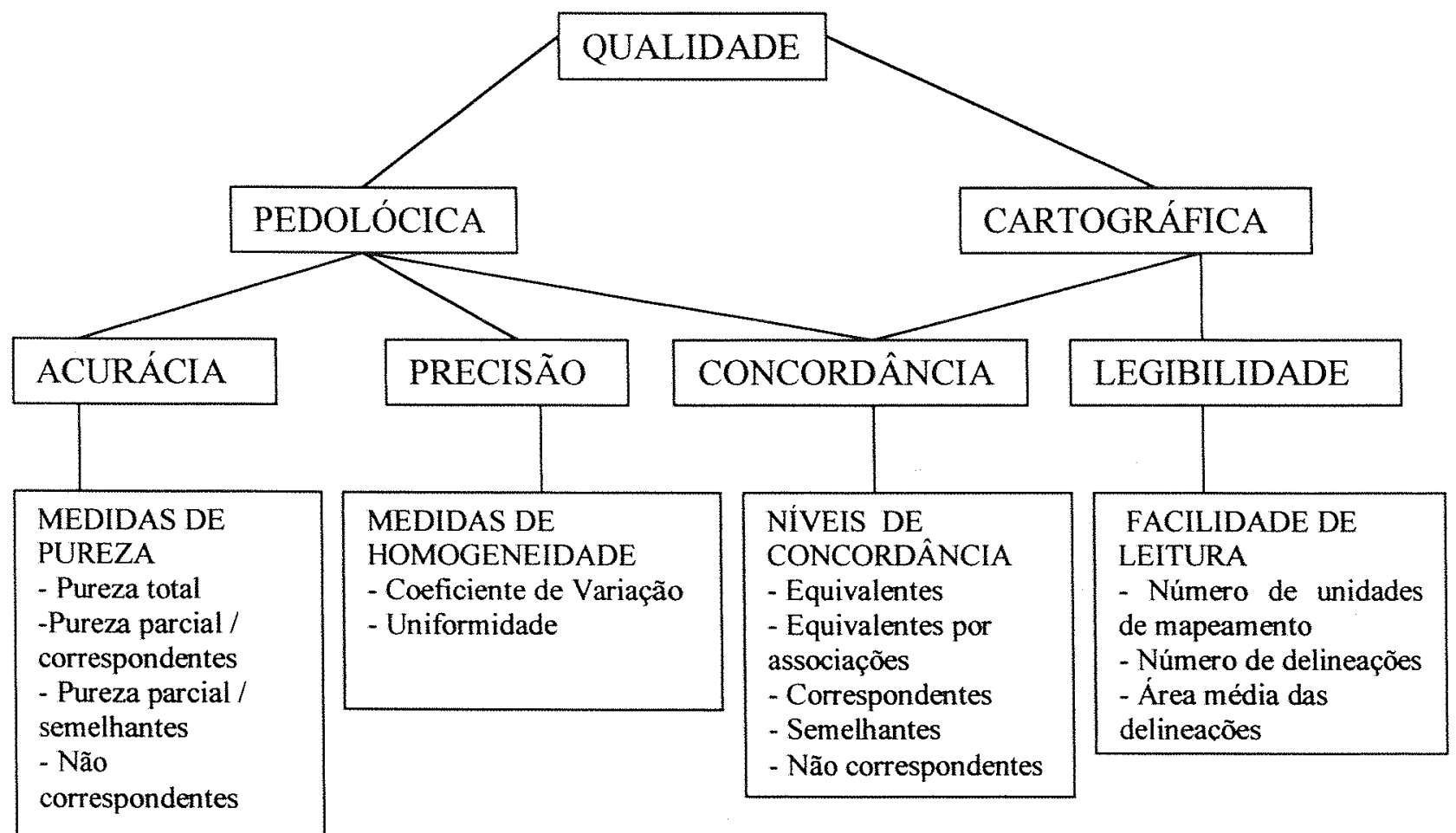

Figura 10- Diagrama para avaliação da qualidade pedológica e cartográfica dos mapas de solos (adaptado de Marsman \& Gruijter, 1986). 


\subsubsection{Precisão dos atributos de solos}

Os atributos dos solos, nos três mapas, foram avaliados utilizando-se o intervalo de confiança para a média e o coeficiente de variação, que são parâmetros estatísticos que norteiam a dispersão de valores. Além desses parâmetros utilizou-se o índice de uniformidade.

Os parâmetros estatísticos foram calculados para 24 atributos de solos: Areia muito grossa (AMG), Areia grossa (AG), Areia média (AM), Areia Fina (AF), Areia muito fina (AMF), Areia total (AT), Silte, Argila, \% de Floculação da argila, pH em $\mathrm{H}_{2} \mathrm{O}, \mathrm{pH}$ em KCl, $\mathrm{pH}$ em $\mathrm{CaCl}_{2}$, Matéria Orgânica (MO), Fósforo assimilável (P), $\mathrm{K}$ trocável $(\mathrm{K})$, Cálcio trocável $(\mathrm{Ca})$, Magnésio trocável $(\mathrm{Mg})$, Alumínio trocável $(\mathrm{Al})$, Hidrogênio + Alumínio trocável (H+Al), S (soma de bases), CTC (CTC do solo), Targ (CTC da fração argila), V\% (saturação por bases), m (saturação por alumínio).

A avaliação da precisão dos mapas semidetalhado e detalhado-1991 foi feita utilizando-se os dados analíticos das observações obtidas no levantamento detalhado2000. A base de dados georeferenciada do levantamento detalhado-2000 foi sobreposta aos mapas semidetalhado e detalhado-1991, permitindo as medidas de avaliação da precisão do mapa semidetalhado, produzido pelo IAC (Oliveira \& Prado, 1989) e do mapa detalhado-1991, produzido por Sparovek (1991).

A avaliação dos atributos dos solos foi feita utilizando-se o horizonte A e horizonte $\mathrm{B}$, ou horizonte $\mathrm{C}$ na ausência do horizonte $\mathrm{B}$.

- Intervalo de confiança - O intervalo de confiança para a média expressa uma idéia da precisão da estimativa da média, em termos probabilísticos, e foi calculado conforme a seguinte equação (Nogueira,1997):

$$
I C(\mu)_{(1-\alpha)} \Rightarrow \mu \pm z . S(\mu)
$$

$(1-\alpha) \rightarrow$ o coeficiente de confiança;

$\mu \rightarrow$ a estimativa da média;

$\mathrm{S}(\mu) \rightarrow$ o desvio padrão da média, associado a $(\mathrm{n}-1)$ graus de liberdade; 
$\mathrm{z} \rightarrow$ variável independente da equação de distribuição normal. No caso dos cálculos utilizou-se o valor $z=1,96$ representando um nível de significância de $95 \%$.

- Coeficiente de variação - O coeficiente de variação, medida de dispersão que expressa percentualmente o desvio padrão por unidade da média, foi calculado segundo Nogueira (1997), da seguinte forma:

$$
C V=\frac{d p}{\mu} 100
$$

$\mathrm{dp} \rightarrow$ estimativa do desvio padrão;

$\mu \rightarrow$ estimativa da média.

- Índice de uniformidade - O Índice de uniformidade é a fração da variância (Coeficiente de Variação) de algum atributo do solo sobre a totalidade da área na qual é subdividida por unidades de mapeamento ou classes de solos (Burrough et al., 1971).

$$
\begin{aligned}
\text { Uniformidade } & =[1-(\mathrm{CV} \text { da Unidade de mapeamento }) /(\mathrm{CV} \text { da microbacia })] \times 100 \\
& =(1-\mathrm{CV} \text { relativo }) \times 100
\end{aligned}
$$

A uniformidade de uma propriedade do solo ocorre entre um valor $<0$ a $100 \%$, respectivamente, menor e maior uniformidade. Os valores negativos ocorrem quando o coeficiente de variação da unidade de mapeamento é maior que o coeficiente de variação geral da microbacia.

- Índices médios - Com a finalidade de facilitar a comparação das unidades de mapeamento dentro de cada mapa e entre os mapas de solos, foram criados 3 índices médios, IM1, IM2 e IM3, que resumem os atributos de solos, a seguir:

IM1 - Média dos CVs ou Uniformidade de todos os atributos de solos.

IM2 - Média dos CVs ou Uniformidade dos seguintes atributos de solos (AG, AF, AT, Silte, Argila, $\mathrm{pH} \mathrm{H}_{2} \mathrm{O}, \mathrm{MO}, \mathrm{P}, \mathrm{Ca}, \mathrm{K}, \mathrm{Al}, \mathrm{H}+\mathrm{Al}, \mathrm{S}, \mathrm{T}$, Targ, V\% e m).

IM3 - Média dos CVs ou Uniformidade dos seguintes atributos de solos (Areia total, Argila, Targ, V\% e m). Esses atributos são os mais importantes para a definição da classificação dos solos. 
- Comparação dos mapas - Para o cálculo estatístico (visando a comparação dos mapas) utilizou-se apenas unidades de mapeamento que possuíam 3 ou mais observações (tradagens ou perfis).

\section{CV mapa $=\Sigma($ wi.CVi $) / \Sigma$ wi}

Sendo: wi = área da unidade de mapeamento $\mathrm{CVi}=\mathrm{CV}$ da unidade de mapeamento.

\section{Unif. mapa $=\Sigma($ wi.Unifi $) / \Sigma w i$}

Sendo: $w i$ = área da unidade de mapeamento

Unifi = Índice de Uniformidade da unidade de mapeamento.

Para comparação dos CV\% e índice de uniformidade entre os mapas de solos, foi determinado uma média desses parâmetros para cada atributo de solos para cada um dos três mapas de solos estudados, área do Grid e área total (Geral); esta média foi ponderada pela área de cada unidade de mapeamento que apresentavam 3 ou mais observações.

Os atributos de solos foram separados em três grupos de acordo com os seus CV\% médios e índice de uniformidade médio para cada mapa de solos:

$$
\begin{aligned}
& \text { Grupo I }-\mathrm{CV}<40 \% \text { e Unif. } \geq 40 \% \text {. } \\
& \text { Grupo II }-40 \leq \mathrm{CV}<70 \% \text { e } 10 \leq \text { Unif. }<40 \% \text {. } \\
& \text { Grupo III }-\mathrm{CV}>70 \% \text { e Unif. }<10 \% \text {. }
\end{aligned}
$$

- "Grid" - Visando conhecer a variabilidade dos atributos de solos em curta distância, determinou-se os parâmetros estatísticos de 51 observações pertencentes à área do grid (distância entre cada observação $=20$ metros) que ocorriam na unidade de mapeamento $A C t 2$ (associação de ALISSOLOS CRÔMICOS Argilúvicos abrúpticos + ARGISSOLOS VERMELHO-AMARELOS Alumínicos abrúpticos ambos A moderado textura arenosa/média) do mapa detalhado- 2000 . 
- Teste $\mathfrak{t}$ - Para comparação entre as unidades de mapeamento com 3 ou mais amostras (duas a duas), dentro de cada mapa de solos, foi realizado o teste t para comparação de médias entre duas amostras presumindo variâncias diferentes para os atributos de solos mais importantes com fins de classificação - Teor de argila no horizonte A (Arg A), Teor de argila no horizonte B (ou horizonte subsuperficial) (Arg B), Atividade da argila no horizonte B (Targ B), Saturação de bases no horizonte B (V\% B) e saturação de alumínio no horizonte B (m B).

$\mathrm{O}$ teste $\mathrm{t}$ foi utilizado para testar a hipótese de que as unidades de mapeamento possuem diferenças estatísticas entre as suas médias, para alguns atributos físicoquímicos de solos utilizados para fins de classificação de solos; além de diferenças morfológicas, tais como: horizontes diagnósticos, profundidade do solum e espessura do horizonte A, utilizados para classificar o solo. Para comparação entre as unidades de mapeamento é importante, também, conhecer a legenda de identificação dos mapas (itens 3.2, 3.3 e 4.1) e os dados resumidos desses mapas (Tabelas 7, 9 e 10).

\subsubsection{Concordância dos mapas de solos}

A concordância dos mapas de solos foi feita através de matrizes de sobreposição dos mapas, fazendo-se três sobreposições. Os mapas foram sobrepostos digitalmente através do SIG TNT MIPs. A $1^{\text {a }}$ sobreposição foi entre o mapa semidetalhado, escala 1:100.000, e o mapa detalhado-2000, escala 1:10.000, a $2^{\mathrm{a}}$ sobreposição entre o mapa semidetalhado, escala 1:100.000, e o mapa detalhado-1991, escala 1:10.000; as duas primeiras sobreposições foram feitas para avaliar as escalas diferentes dos levantamentos. A $3^{\circ}$ sobreposição entre o mapa detalhado-2000, escala 1:10.000, e mapa detalhado-1991, escala 1:10.000, foi feita com a intenção de avaliar as diferenças entre os levantamentos executados por equipes diferentes.

Estas sobreposições tiveram a finalidade de responder as seguintes questões básicas:

1) O levantamento semidetalhado é uma simplificação do levantamento detalhado? 
2) O levantamento detalhado tem pouca relação com o levantamento semidetalhado?

3) O levantamento detalhado é dependente da equipe executora?

Para a sobreposição dos mapas foram utilizados 5 niveis de identificação de concordância entre as unidades de mapeamento:

1- EQUTVALENTES (Equivalentes) - Utilizado para as unidades que são exatamente iguais em relação às suas propriedades utilizadas para classificação. Exemplo: Unidade de mapeamento PVAe3 (mapa detalhado-2000) versus Unidade de mapeamento PV5 (mapa detalhado-1991) - PVAe3 = ARGISSOLOS VERMELHOAMARELOS Eutróficos abrúpticos (PODZÓLICO VERMELHO-AMARELO Tb eutrófico Abrupto) A moderado textura média/argilosa vs. PV5 = Podzólico Vermelho-Amarelo, eutrófico, Tb, A moderado, textura média/argilosa.

2- EQUIVALENTES COM ASSOCIAÇÕES (Equiv. c/Assoc.) - (Unidades de mapeamento que são associações complexas e simples) - Utilizado para as unidades (associações ou complexos) que contenham unidades equivalentes do outro mapa. Exemplo: Unidade de mapeamento ACtq (mapa detalhado-2000) vs. Unidade de mapeamento PV7 + Li5 (mapa semidetalhado) - ACtq $=$ Associação de ALISSOLOS CRÔMICOS Argilúvicos abrúpticos arênicos + ARGISSOLOS VERMELHO-AMARELOS Alumínicos abrúpticos arênicos (PODZÓLICO VERMELHO-AMARELO $\mathrm{Ta}$ ou $\mathrm{Tb}$ álico Abrupto Arênico) ambos A moderado textura arenosa/média vs. PV7 = Grupamento indiscriminado de PODZÓLICOS VERMELHO-AMARELOS abruptos, A moderado e espesso, textura arenosa/média (Unidade Serrinha).

3- CORRESPONDENTES (Correspondentes) - Utilizado com unidades de mapeamento com associações ou simples que possuam alguma equivalência em textura e profundidade nas ordens ALISSOLOS, ARGISSOLOS E LUVISSOLOS no mapa detalhado-2000 e Podzólicos no mapa semidetalhado e mapa detalhado-1991; e textura para os NEOSSOLOS LÍTÓLICOS ou Solos Litólicos. Exemplo: Unidade 
de mapeamento RLe4 (mapa detalhado-2000) vs. Unidade de mapeamento Li1 (mapa detalhado-1991) - RLe4 = NEOSSOLOS LITÓLICOS Eutróficos típicos Ta ou Tb (SOLOS LITÓLICOS Ta ou Tb eutróficos) A moderado textura argilosa ou média substrato folhelho e siltíto da Formação Corumbataí vs. Li 1 = Solo Litólico, eutrófico, Ta ou $\mathrm{Tb}, \mathrm{A}$ moderado ou chernozêmico, textura média, substrato siltítos da Formação Corumbataí.

4- SEMELHANTES (Semelhantes.) - Utilizado para as unidades que apresentam a mesma classe de solos (Subordem no Sistema Brasileiro de Classificação de Solos e (Embrapa, 1999)). OBS. Subordens que apresentam horizonte B textural (ALISSOLOS, ARGISSOLOS E LUVISSOLOS no mapa detalhado-2000) foram consideradas semelhantes. Exemplo: Unidade de mapeamento ACt2 (mapa detalhado-2000) vs. Unidade de mapeamento PV9 (mapa semidetalhado) $-\mathbf{A C t} 2=$ Associação de ALISSOLOS CRÔMICOS Argilúvicos abrúpticos + ARGISSOLOS VERMELHO-AMARELOS Alumínicos abrúpticos (PODZÓLICO VERMELHOAMARELO Ta ou Tb álico Abrupto) ambos A moderado textura arenosa/média vs. PV9 =Grupamento indiscriminado de PODZÓLICOS VERMELHO-AMARELOS Tb abruptos, A moderado, textura arenosa/argilosa ou média/argilosa (Unidade Santa Cruz).

5- NÃO CORRESPONDENTES (Não Corresp.) - As unidades não apresentam nenhum nível de concordância quanto às classes de solos (Subordens no Sistema Brasileiro de Classificação de Solos, Embrapa (1999). Exemplo: Unidade de mapeamento PVAe3 (mapa detalhado-2000) vs. Unidade de mapeamento Cbl (mapa detalhado1991) - PVAe3 = ARGISSOLOS VERMELHO-AMARELOS Eutróficos abrúpticos (PODZÓLICO VERMELHO-AMARELO Tb eutrófico Abrupto) A moderado textura média/argilosa vs. Cb1 = Cambissolo, eutrófico ou distrófico, $\mathrm{Ta}$ ou $\mathrm{Tb}, \mathrm{A}$ moderado, textura argilosa.

Para efeito de discussão será considerado como "classe de solos" o $2^{\circ}$ nível categórico - Subordens - do Sistema Brasileiro de Classificação de Solos (Embrapa, 1999) no mapa detalhado-2000. 
Na discussão das informações de concordância, consideramos uma concordância muito baixa, quando os mapas sobrepostos apresentam menos que $40 \%$ de suas áreas nas classes de concordância Equivalentes, Equivalentes com Associações e Correspondentes, que são consideradas classes de alta concordância. Enquanto que concordância baixa foi considerada quando os mapas sobrepostos apresentam entre $40 \mathrm{e}$ $55 \%$ de suas áreas nas classes de alta concordância. Entre 55 e $70 \%$ seria concordância média e acima de $70 \%$ os mapas apresentariam alta concordância.

\section{Metodologia de sobreposição dos mapas}

$1^{\mathrm{o}}$ passo - de posse da legenda de cada mapa, foi feito uma planilha contendo uma matriz com todos os cruzamentos possíveis entre cada um dos pares das três sobreposições. Para cada unidade de mapeamento foram realizados cruzamentos com todas as unidades de mapeamento dos outros mapas e identificado o nível de concordância do cruzamento.

$2^{\circ}$ passo - Os mapas foram sobrepostos aos pares e identificados os cruzamentos que efetivamente ocorreram entre os mapas, essas novas unidades foram identificadas pelo nível de concordância, formando um novo mapa.

Nas sobreposições dos mapas, foram retiradas as áreas ocupadas com represas e área urbana, que são as mesmas nos três mapas sobrepostos. Logo a área total da microbacia para efeito de concordância espacial dos solos foi reduzida para 1943,16 ha.

Observação - É importante lembrar que o mapa detalhado-2000, utilizado para a sobreposição com os demais mapas, originalmente foi feito com a classificação antiga de solos (Embrapa, 1988). Portanto as sobreposições foram feitas antes da equivalência ou correlação das unidades taxonômicas do mapa detalhado-2000.

Como avaliação da sobreposição dos mapas de solos serão apresentados 3 novos mapas, um mapa para cada sobreposição. 


\subsubsection{Pureza dos mapas de solos}

A Pureza é uma medida de qualidade que indica o grau no qual os critérios de classificação mostrados no mapa são satisfeitos pelas propriedades dos perfis de solos no campo. Elas refletem a acurácia com que as ocorrências de unidades taxonômicas no campo são indicadas no mapa.

A pureza dos mapas de solos foi avaliada através de novas sondagens externas. Para tanto foram escolhidos 29 pontos selecionados randomicamente através do sorteio de coordenadas. No campo foram localizadas as coordenadas sorteadas, sendo utilizado um aparelho de GPS (como descrito no item 3.4.4) e os solos foram amostrados e descritos, através de tradagem (como descrito no item 3.4.3). Os pontos amostrados foram corrigidos em escritório para determinação da posição exata (como descrito no item 3.4.4).

As novas sondagens externas foram plotadas em cada um dos mapas de solos estudados, sendo então relacionadas com as unidades de mapeamento. Foi, então, calculado a percentagem de pontos randômicos (novas sondagens externas) nos quais os mapas tenham indicado corretamente a classe de solos a qual pertencem.

Classes de Pureza: a percentagem de pontos randômicos nos quais os mapas tenham corretamente predito, parcialmente predito ou não preditos a classe de solos que pertence. Foi calculada como a média da proporção de cada unidade de mapeamento ocupada por suas classes de solos dominantes, em relação a todas as unidades de mapeamento, através da fórmula:

$$
\sum_{n}^{1} a_{1} \frac{c_{1}}{c_{1}}
$$

Sendo:

$\mathbf{a}_{1}=$ área da unidade de mapeamento 1 expressa como a fração do mapa total (fração do somatório das unidades de mapeamento que foram amostradas).

$\mathbf{c}_{1}=\mathrm{O}$ número de pontos de observação que tenham acertado total, parcialmente ou não tenham acertado a classe de solos da unidade de mapeamento de acordo com a classe de pureza. 
$\mathrm{C}_{1}=\mathrm{O}$ número total de pontos observados na unidade de mapeamento 1.

Para a avaliação da pureza foram utilizadas as seguintes CLASSES DE PUREZA, derivadas parcialmente do item 3.5.1:

1 - PUREZA TOTAL - é definida como a proporção dos perfis de solos, novas sondagens externas, que preenchem exatamente todos os critérios de classificação da unidade, ou seja, a classificação do solo é a mesma da unidade de mapeamento na qual se encontra (pode ser utilizado para unidades compostas por associações).

2 - PUREZA PARCIAL/CORRESPONDENTES - é definida como a proporção dos perfis de solos, novas sondagens externas, que preenchem parcialmente os critérios de classificação da unidade - possuem a mesma textura, profundidade e espessura do horizonte A nos solos com horizonte B textural; ordens ALISSOLOS, ARGISSOLOS E LUVISSOLOS no mapa detalhado-2000 e Podzólicos no mapa semidetalhado e mapa detalhado-1991; e textura para os NEOSSOLOS LÍTICOS ou Solos Litólicos.

3 - PUREZA PARCIAL/SEMELHANTES - é definida como a proporção dos perfis de solos, novas sondagens externas, que preenchem parcialmente os critérios de classificação da unidade - possuem a mesma classe de solos, ou no caso dos solos com horizonte B textural pertencerem aos podzólicos, ou ALISSOLOS, ARGISSOLOS E LUVISSOLOS, Ordem no Sistema Brasileiro de Classificação de Solos (Embrapa, 1999).

4 - NÃO CORRESPONDENTES - é definida como a proporção dos perfis de solos, novas sondagens externas, que não apresentam nenhum dos critérios anteriores.

\subsubsection{Relação entre pureza e concordância dos mapas de solos}

Para relacionar a pureza, obtida a partir das novas sondagens externas, e a concordância dos mapas de solos, o primeiro passo foi plotar as novas sondagens externas sobre o mapa resultante das sobreposições dos mapas de solos: Sobreposição do mapa detalhado-2000 x mapa semidetalhado - D2000 x Semi; Sobreposição do mapa detalhado-1991 x mapa semidetalhado - D1991 x Semi; e Sobreposição do mapa 
detalhado-2000 x mapa detalhado-1991 - D2000 x D1991). Em seguida foram determinadas as classes de concordância onde se encontraram as novas sondagens externas. Foram estabelecidas as seguintes classes de concordância: Alta Concordância (Classes de concordância Equivalentes, Equivalentes com Associações $e$ Correspondentes) e Baixa Concordância (Classes Semelhantes e Não Correspondentes). O segundo passo foi utilizar as classes de pureza das novas sondagens externas dos mapas de solos, que serão apresentadas na Tabela 19 (item 4.4.1) e resumidamente na Tabela 20 (item 4.4.6), que foram englobadas nas classes Alta Pureza (Classes Pureza Total e Pureza Parcial/Correspondentes) e Baixa Pureza (Classes Pureza Parcial/Semelhantes e Não Correspondentes).

\subsubsection{Facilidade de leitura dos mapas de solos}

O uso dos mapas de solos é também influenciado pelos aspectos cartográficos que determinam a facilidade de leitura do mapa de solos. Este parâmetro é importante quando se consideram usuários tradicionais dos mapas de solos, apresentando menor importância para uso em SIGs.

Não há métodos objetivos que determinem a legibilidade dos mapas de solos. Neste trabalho a legibilidade foi determinada através do número de unidades de mapeamento, número de áreas delineadas e média do tamanho das áreas delineadas. As informações estão presentes nas Tabelas 4, 5 e 6 (itens 3.2, 3.3 e 4.1). 


\section{RESULTADOS E DISCUSSÃO}

\subsection{Os Solos da microbacia}

\subsubsection{Caracterização dos solos}

Através do levantamento detalhado de solos-2000 da microbacia hidrográfica do Córrego do Ceveiro foram identificados de acordo com o Sistema Brasileiro de Classificação de Solos (Embrapa, 1999) oito ordens de solos: ALISSOLOS, ARGISSOLOS, LUVISSOLOS, NITOSSOLOS, CHERNOSSOLOS, CAMBISSOLOS, NEOSSOLOS e GLEISSOLOS; esses solos correspondem a sete classes de solos na antiga classificação (Embrapa, 1988): Podzólico VermelhoAmarelo; Podzólico Vermelho-Escuro; Terra Roxa Estruturada; Cambissolo; Solos Aluviais; Solos Litólicos; e Glei Pouco Húmico.

Os solos da microbacia compreendem 34 classes ao nível de subgrupo: ALISSOLOS CRÔMICOS Argilúvicos abrúpticos; ALISSOLOS CRÔMICOS Argilúvicos abrúpticos arênicos*; ALISSOLOS CRÔMICOS Argilúvicos abrúpticos lépticos*; ARGISSOLOS AMARELOS Distróficos epiáquicos álicos; ARGISSOLOS VERMELHO-AMARELOS Alumínicos abrúpticos*; ARGISSOLOS VERMELHOAMARELOS Alumínicos abrúpticos arênicos*; ARGISSOLOS VERMELHOAMARELOS Alumínicos abrúpticos lépticos*; ARGISSOLOS VERMELHOAMARELOS Distróficos abrúpticos arênicos*; ARGISSOLOS VERMELHOAMARELOS Distróficos abrúpticos lépticos*; ARGISSOLOS VERMELHOAMARELOS Distróficos Ta abrúpticos*; ARGISSOLOS VERMELHO-AMARELOS Eutróficos abrúpticos; ARGISSOLOS VERMELHO-AMARELOS Eutróficos abrúpticos arênicos*; ARGISSOLOS VERMELHO-AMARELOS Eutróficos abrúpticos 
lépticos*; ARGISSOLOS VERMELHOS Eutróficos típicos; CAMBISSOLOS HÁPLICOS Ta Alumínicos lépticos; CAMBISSOLOS HÁPLICOS Ta Eutróficos lépticos; CAMBISSOLOS HÁPLICOS Ta Eutróficos típicos; CAMBISSOLOS HÁPLICOS Tb eutróficos lépticos; CAMBISSOLOS HÁPLICOS Tb Eutróficos típicos; CHERNOSSOLOS ARGILÚVICOS Órticos típicos; GLEISSOLOS HÁPLICOS Indiscriminados; LUVISSOLOS CRÔMICOS Pálicos típicos; LUVISSOLOS CRÔMICOS Pálicos arênicos abrúpticos*; LUVISSOLOS CRÔMICOS Órticos abrúpticos*; NITOSSOLOS VERMELHOS Eutróficos argissólicos*; NITOSSOLOS VERMELHOS Eutróficos típicos; NEOSSOLOS FLÚVICOS Tb Eutróficos; NEOSSOLOS LITÓLICOS álicos típicos*; NEOSSOLOS LITÓLICOS Eutróficos típicos; NEOSSOLOS LITÓLICOS Eutróficos chernossólicos; NEOSSOLOS LITÓLICOS Distróficos típicos álicos; NEOSSOLOS LITÓLICOS Eutróficos típicos; NEOSSOLOS INDIFERENCIADOS*. *Classes sugeridas para criação.

De acordo com suas especificidades de caráter físico, químico ou morfológicos, estas subordens de solos foram responsáveis pela definição de quarenta e seis unidades de mapeamento, compostas de unidades simples e associações, dispostas na MHCC, conforme mostrado na Figura 11. As características químicas e granulométricas das unidades de mapeamento do mapa detalhado de solos-2000 são mostradas no Anexo, sendo apresentados também algumas estatísticas básicas, tais como: Média $(\mathrm{X})$, limite de confiança (t.Sx), mínimo, máximo, coeficiente de variação $(\mathrm{CV})$ e Índice de Uniformidade.

Dominam na microbacia os solos que apresentam horizonte $\mathrm{B}$ textural (AC, PVA e TC) e NEOSSOLOS LITÓLICOS (RL). A Tabela 6 mostra as áreas totais e relativas das unidades de mapeamento, indicando que os solos com horizonte B textural ocorrem em $43 \%$ da área da microbacia, enquanto que os NEOSSOLOS LITÓLICOS ocupam $35 \%$, vindo em seguida os Cambissolos com $11 \%$. A unidade de mapeamento RLe4 - NEOSSOLOS LITÓLICOS Eutróficos típicos Ta ou Tb A moderado textura argilosa ou média substrato folhelho e siltíto da Formação Corumbataí, ocupa $16 \%$ da área da microbacia. 

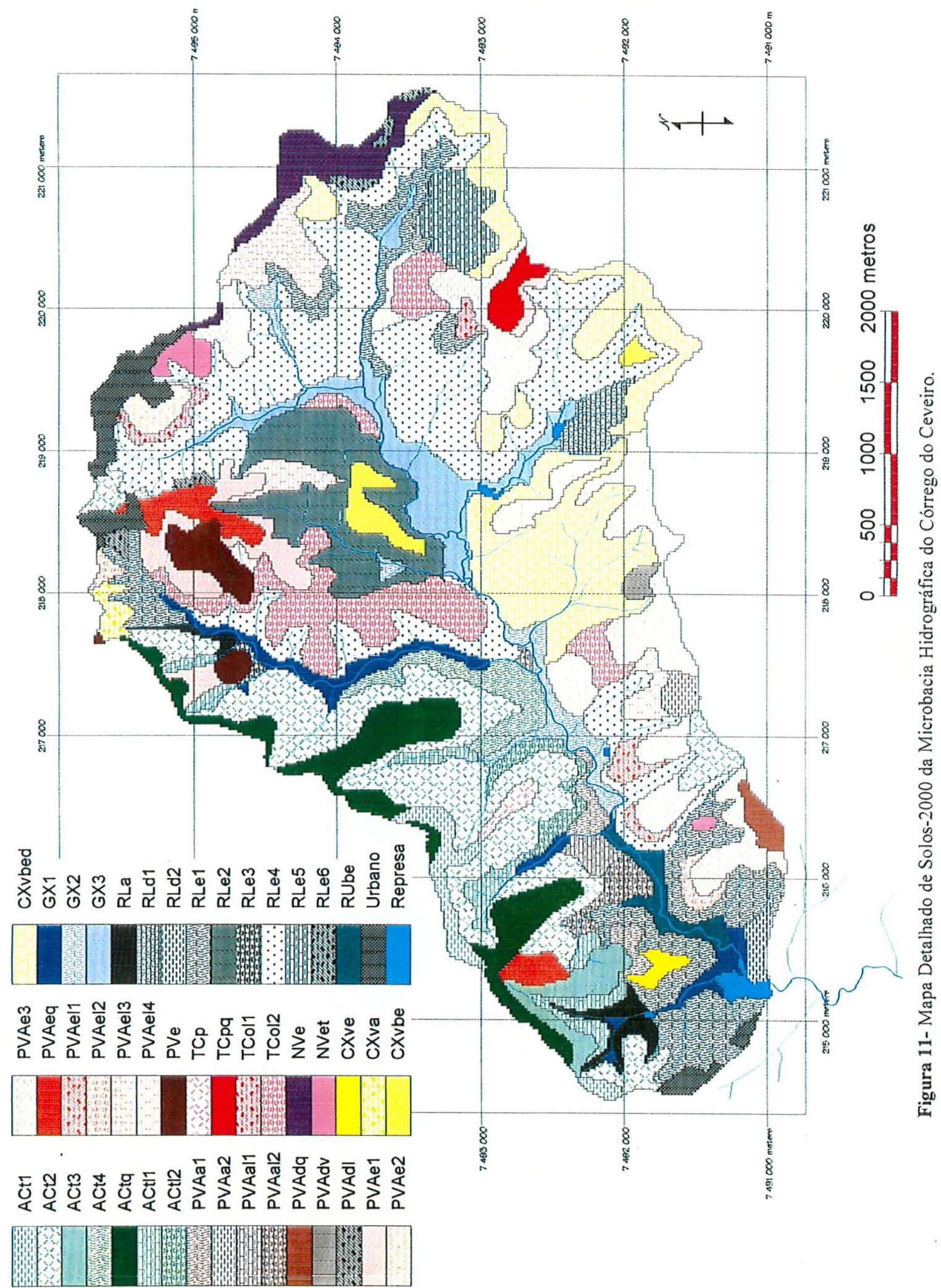


\section{Legenda do mapa detalhado de solos-2000}

ACt1 = ALISSOLOS CRÔMICOS Argilúvicos abrúpticos A moderado textura arenosa/média

ACt2 = Associação complexa de ALISSOLOS CRÔMICOS Argilúvicos abrúpticos + ARGISSOLOS VERMELHO-AMARELOS Alumínicos abrúpticos ambos A moderado textura arenosa/média

ACt3 = Ass. complexa de ALISSOLOS CRÔMICOS Argilúvicos abrúpticos + ARGISSOLOS VERMELHOAMARELOS Alumínicos abrúpticos ambos $\mathrm{A}$ fraco textura arenosa/média fase erodida e não erodida

ACt4 = ALISSOLOS CRÔMICOS Argilúvicos abrúpticos A moderado textura média/argilosa

ACtq = Associação complexa de ALISSOLOS CRÔMICOS Argilúvicos abrúpticos arênicos* + ARGISSOLOS VERMELHO-AMARELOS Alumínicos abrúpticos arênioos* ambos A moderado textura arenosa/média

ACt11 = Associação complexa de ALISSOLOS CRÔMICOS Argilúvicos abrúpticos lépticos* + ARGISSOLOS VERMELHO-AMARELOS Aluminicos abrúpticos lépticos* ambos A moderado textura arenosa/média

ACt12 = ALISSOLOS CRÔMICOS Argilúvicos abrúpticos lépticos* A moderado textura arenosa/argilosa

PVAa1 = ARGISSOLOS VERMELHO-AMARELOS Alumínicos abrúpticos* A moderado textura média/argilosa

PVAa2 = ARGISSOLOS VERMELHO-AMARELOS Alumínicos abrúpticos* A moderado textura média/muito argilosa

PVAal1 = ARGISSOLOS VERMELHO-AMARELOS Alumínicos abrúpticos lépticos* A moderado textura arenosa/argilosa

PVAa12 = ARGISSOLOS VERMELHO-AMARELOS Alumínicos abrúpticos lépticos* A moderado textura média/argilosa

PVAdq $=$ ARGISSOLOS VERMELHO-AMARELOS Distróficos abrúpticos arênicos* A moderado textura arenosa/média

PVAdI = ARGISSOLOS VERMELHO-AMARELOS Distróficos abrúpticos lépticos* A moderado textura arenosa/média

PVAdv $=$ ARGISSOLOS VERMELHO-AMARELOS Ta Distróficos* abrúpticos A moderado textura média/muito argilosa

PVAe1 = ARGISSOLOS VERMELHO-AMARELOS Eutróficos abrúpticos A moderado textura arenosa/média

PVAe2 = ARGISSOLOS VERMELHO-AMARELOS Eutróficos abrúpticos A moderado textura arenosa/argilosa

PVAe3 ARGISSOLOS VERMELHO-AMARELOS Eutróficos abrúpticos A moderado textura média/argilosa

PVAeq $=$ ARGISSOLOS VERMELHO-AMARELOS Eutróficos abrúpticos arênicos* A moderado textura arenosa/média

PVAel = ARGISSOLOS VERMELHO-AMARELOS Eutróficos abrúpticos lépticos* A moderado textura média/argilosa

PVAel2 = Associação complexa de ARGISSOLOS VERMELHO-AMARELOS Eutróficos abrúpticos lépticos* + ALISSOLOS CRÔMICOS Argilúvicos abrúpticos lépticos* ambos A moderado textura média/argilosa

PVAel3 = Associação complexa de ARGISSOLOS VERMELHO-AMARELOS Eutróficos abrúpticos lépticos* + ARGISSOLOS VERMELHO-AMARELOS Eutróficos abrúpticos ambos A moderado textura média/argilosa

PVAel4 = ARGISSOLOS VERMELHO-AMARELOS Eutróficos abrúpticos lépticos* A moderado textura média/muito argilosa

PVe = Associação complexa de ARGISSOLOS VERMELHOS Eutróficos típicos textura média/argilosa + ARGISSOLOS VERMELHOS Eutróficos típicos textura média/muito argilosa ambos A moderado

TCp = Associação complexa de LUVISSOLOS CRÔMICOS Pálicos típicos + ARGISSOLOS VERMELHOS Eutróficos típicos ambos A moderado textura média/argilosa

TCpq = Associação complexa de LUVISSOLOS CRÔMICOS Pálicos arênicos abrúpticos* + ARGISSOLOS VERMELHO-AMARELOS Eutróficos abrúpticos arênicos ambos A moderado textura arenosa/ média

TColl = LUVISSOLOS CRÔMICOS Órticos abrúpticos A moderado textura arenosa/argilosa

TCol2 = Associação complexa de LUVISSOLOS CRÔMICOS Órticos abrúpticos + ARGISSOLOS VERMELHOAMARELOS Distróficos abrúpticos lépticos* ambos A moderado textura média/argilosa

NVet = Associação de NITOSSOLOS VERMELHOS Eutróficos argissólicos* A moderado + CHERNOSSOLOS ARGILÚVICOS Órticos típicos ambos textura argilosa

NVe = Associação complexa de NITOSSOLOS VERMELHOS Eutróficos típicos + NITOSSOLOS VERMELHOS 
Eutróficos argissólicos ambos A moderado textura argilosa/muito argilosa + CHERNOSSOLOS ARGILÚVICOS Órticos típicos textura argilosa/muito argilosa + NEOSSOLOS LITÓLICOS Eutróficos típicos $\mathrm{Tb}$ A moderado + NEOSSOLOS LITÓLICOS Eutróticos chernossólicos ambos textura argilosa substrato diabásio

CXve = CAMBISSOLOS HÁPLICOS Ta Eutróficos lépticos A moderado textura média substrato siltíto da Formação Corumbataí

CXva = CAMBISSOLOS HÁPLICOS Ta Aluminicos lépticos A moderado textura média substrato siltito da Formação Corumbatai

CXvbe $=$ Associação complexa de CAMBISSOLOS HÁPLICOS Ta Eutróficos típicos + CAMBISSOLOS HÁPLICOS $\mathrm{Tb}$ Eutróficos típicos ambos A moderado textura argilosa substrato folhelho da Formação Corumbataí

CXvbed = Associação complexa de CAMBISSOLOS HÁPLICOS Ta eutróficos lépticos + CAMBISSOLOS HÁPLICOS Tb eutróficos lépticos + NEOSSOLOS LITÓLICOS Eutróficos típicos todos A moderado textura argilosa substrato folhelho da Formação Corumbatai

GX1 = Associação complexa de GLEISSOLOS HÁPLICOS indiscriminados A moderado textura arenosa, arenosa/média e arenosa/argilosa + NEOSSOLOS FLÚVICOS Tb Eutróficos A moderado textura média e média/argilosa + NEOSSOLOS INDIFERENCIADOS*

GX2 = Associação complexa de GLEISSOLOS HÁPLICOS indiscriminados A moderado textura média/argilosa e argilosa + NEOSSOLOS INDIFERENCIADOS*

GX3 = Associação complexa de GLEISSOLOS HÁPLICOS indiscriminados A moderado textura média/argilosa e argilosa + NEOSSOLOS FLÚVICOS Tb Distróficos A moderado textura média e média/argilosa + ARGISSOLOS AMARELOS Distróficos epiáquicos álicos A moderado textura média/argilosa + NEOSSOLOS INDIFERENCIADOS*

RLa = NEOSSOLOS LITÓLICOS álicos típicos* A moderado textura arenosa e média substrato arenito da Formação Pirambóia

RLd1 = NEOSSOLOS LITÓLICOS Distróticos típicos A moderado textura média substrato siltíto da Formação Corumbataí

RLd2 = NEOSSOLOS LITÓLICOS Distróficos típicos A moderado textura argilosa cascalhenta substrato folhelho da Formação Corumbataí

RLe1 = NEOSSOLOS LITÓLICOS Eutróficos típicos A moderado textura média substrato siltíto e folhelho da Formação Corumbataí

RLe2 = NEOSSOLOS LITÓLICOS Eutróficos típicos A moderado textura argilosa substrato folhelho da Formação Corumbatai

RLe3 = NEOSSOLOS LTTÓLICOS Eutróficos típicos textura média + NEOSSOLOS LITÓLICOS Eutróficos típioos textura argilosa ambos A moderado substrato Diabásio

RLe4 = NEOSSOLOS LITÓLICOS Eutróficos típicos textura argilosa + NEOSSOLOS LITÓLICOS Eutróficos típicos textura média ambos A moderado substrato folhelho e siltito da Formação Corumbataí

RLe5 = Associação complexa de NEOSSOLOS LITÓLICOS Eutróficos típicos + CAMBISSOLOS HÁPLICOS eutróficos lépticos ambos A moderado textura argilosa substrato folhelho da Formação Corumbatai

RLe6 = Associação complexa de NEOSSOLOS LITÓLICOS Eutróficos típicos A moderado textura média + NEOSSOLOS LTTÓLICOS Eutróficos típicos textura argilosa + NITOSSOLOS VERMELHOS Eutróficos argissólicos* A moderado textura argilosa/muito argilosa + CAMBISSOLOS HÁPLICOS Tb eutróficos lépticos A moderado textura argilosa todos substrato Diabásio.

RUbe = Associação de NEOSSOLOS FLÚVICOS Tb Eutróficos + GLEISSOLOS HÁPLICOS Indiscriminados ambos A moderado textura média e média/argilosa + NEOSSOLOS INDIFERENCIADOS*

Urbano $=$ Área Urbana

Represa $=$ Represas

* Classes sugeridas para cria ção

As classes de solos classificadas no $4^{\circ}$ nível no Sistema Brasileiro de Classificação de Solos (Embrapa, 1999) são correlacionadas com as classes de solos da classificação antiga (Embrapa, 1988) e apresentados no Anexo E. 
Tabela 6- Área total e relativa, número de áreas (delineações) e área média das delineações das unidades de mapeamento do mapa detalhado de solos-2000.

\begin{tabular}{|c|c|c|c|c|}
\hline $\begin{array}{c}\text { Unidade de } \\
\text { Mapeamento }\end{array}$ & Área total & Área relativa & $\begin{array}{l}\text { Número de } \\
\text { áreas }\end{array}$ & Área média \\
\hline & (ha) & $(\%)$ & & (ha) \\
\hline $\mathrm{ACt} 1$ & 20,36 & 1,02 & 2 & 10,18 \\
\hline $\mathrm{ACt} 2$ & 199,00 & 10,00 & 6 & 33,17 \\
\hline $\mathrm{ACt} 3$ & 22,20 & 1,12 & 1 & 22,20 \\
\hline $\mathrm{ACt} 4$ & 29,36 & 1,48 & 1 & 29,36 \\
\hline ACtq & 80,48 & 4,04 & 4 & 20,12 \\
\hline ACtll & 32,40 & 1,63 & 6 & 5,40 \\
\hline $\mathrm{ACt} 2$ & 13,84 & 0,70 & 1 & 13,84 \\
\hline PVAa1 & 12,92 & 0,65 & 2 & 6,46 \\
\hline PVAa2 & 6,96 & 0,35 & 1 & 6,96 \\
\hline PVAal1 & 7,56 & 0,38 & 1 & 7,56 \\
\hline PVAal2 & 13,4 & 0,67 & 2 & 6,70 \\
\hline PVAdq & 8,00 & 0,40 & 1 & 8,00 \\
\hline PVAdl & 4,28 & 0,22 & 2 & 2,14 \\
\hline PVAdv & 4,56 & 0,23 & 1 & 4,56 \\
\hline PVAe1 & 40,4 & 2,03 & 5 & 8,08 \\
\hline PVAe2 & 8,96 & 0,45 & 1 & 8,96 \\
\hline PVAe3 & 158,68 & 7,97 & 10 & 15,87 \\
\hline PVAeq & 25,00 & 1,26 & 3 & 8,33 \\
\hline PVAel1 & 9,52 & 0,48 & 2 & 4,76 \\
\hline PVAel 2 & 8,52 & 0,43 & 2 & 4,26 \\
\hline PVAel3 & 26,8 & 1,35 & 1 & 26,80 \\
\hline PVAel4 & 19,36 & 0,97 & 2 & 9,68 \\
\hline PVe & 23,60 & 1,19 & 3 & 7,87 \\
\hline $\mathrm{TCp}$ & 5,68 & 0,29 & 1 & 5,68 \\
\hline TCpq & 11,32 & 0,57 & 1 & 11,32 \\
\hline TCol1 & 9,92 & 0,50 & 2 & 4,96 \\
\hline TCol2 & 96,28 & 4,84 & 4 & 24,07 \\
\hline NVet & 9,92 & 0,50 & 2 & 4,96 \\
\hline $\mathrm{NVe}$ & 34,28 & 1,72 & 2 & 17,14 \\
\hline CXve & 5,84 & 0,29 & 1 & 5,84 \\
\hline CXva & 7,16 & 0,36 & 1 & 7,16 \\
\hline CXvbe & 17,76 & 0,89 & 2 & 8,88 \\
\hline CXvbed & 190,00 & 9,55 & 5 & 38,00 \\
\hline GX1 & 37,48 & 1,88 & 6 & 6,25 \\
\hline $\mathrm{GX} 2$ & 32,76 & 1,65 & 3 & 10,92 \\
\hline GX3 & 65,72 & 3,30 & 2 & 32,86 \\
\hline
\end{tabular}


Tabela 6- Continuação.

\begin{tabular}{ccccc}
$\begin{array}{l}\text { Unidade de } \\
\text { Mapeamento }\end{array}$ & Área total & Área relativa & $\begin{array}{c}\text { Número de } \\
\text { áreas }\end{array}$ & Área média \\
\hline RLa & (ha) & $\%$ & & (ha) \\
RLd1 & 17,28 & 0,87 & 2 & 8,64 \\
RLd2 & 16,20 & 0,81 & 1 & 16,20 \\
RLe1 & 7,44 & 0,37 & 1 & 7,44 \\
RLe2 & 138,52 & 6,96 & 7 & 19,79 \\
RLe3 & 91,12 & 4,58 & 1 & 91,12 \\
RLe4 & 3,04 & 0,10 & 1 & 2,04 \\
RLe5 & $27,8,88$ & 16,07 & 5 & 63,98 \\
RLe6 & 5,00 & 1,40 & 1 & 27,84 \\
RUbe & 17,56 & 0,25 & 3 & 1,67 \\
Urbano & 39,2 & 0,88 & 1 & 17,56 \\
Represa & 8,04 & 1,97 & 4 & 9,80 \\
Total & 1990,40 & 100,40 & 5 & 1,61 \\
\end{tabular}

Existe grande variação dos solos na microbacia hidrográfica do Córrego do Ceveiro, esta é demonstrada inicialmente pela grande quantidade de unidades de mapeamento no mapa detalhado e também pela impossibilidade de representação dos solos em unidades de mapeamento simples.

A alta variabilidade dos solos da microbacia é principalmente observada na atividade da argila, saturação por bases e saturação por alumínio, principalmente nos solos com horizonte B textural, e na textura dos NEOSSOLOS LITÓLICOS como veremos no item 4.2. Esta variabilidade pode ser explicada pelo tipo de material de origem dos solos, rochas sedimentares das formações Corumbataí e Pirambóia e intrusões de diabásio, e pelo relevo movimentado.

Segundo Demattê et al. (1977), na região de Piracicaba, a grande variação observada nos atributos dos solos, deveu-se à heterogeneidade do material de origem.

O tipo de relevo da microbacia, com predomínio do relevo ondulado, e principalmente o material de origem dificulta e torna quase impossível, no levantamento detalhado, a separação em determinadas pendentes de NEOSSOLOS LITÓLICOS e 
CAMBISSOLOS, que passam a ocorrer associados ou na forma de grupamentos indiferenciados.

Em áreas representativas, onde ocorrem solos com horizonte $\mathrm{B}$ textural, mapeadas como ARGISSOLOS VERMELHO-AMARELOS (PVA), ALISSOLOS CRÔMICOS (AC) e LUVISSOLOS CRÔMICOS (TC) ou com característica lépticas solos pouco profundos - (PVAl, ACtl e TCol), que apresentam pendentes curtas, ocorrem inclusões de NEOSSOLOS LITÓLICOS (RL) próximos às grotas que não são cartograficamente mapeáveis. Em algumas dessas topossequências, os solos variam rapidamente, na pendente em direção a grota (menos de 20 metros) de PVA ou PVAl, AC ou $A C t l$ e TC ou TCol para RL, aparecendo ou não CAMBISSOLOS HÁPLICOS (CX).

Segundo alguns autores (Coelho et al., 1994; Demattê et al., 1992; Scatolini \& Moniz, 1992 e Vidal-Torrado \& Lepsch, 1993) ocorrem variações morfológicas, de classes de solos e atributos de solos ao longo de uma topossequência. Sendo que essas variações foram relacionadas ao material de origem, lençol freático e drenagem local e posição na vertente.

Recentemente, Moniz et al. (1995) constataram que esmectita, ilita, clorita, ilitaclorita, caulinita, vermiculita com hidroxi intercamada e gibbsita (menos freqüentemente), são os minerais mais comuns na fração argila de alguns sedimentos bem como de alguns solos afiliados, ocorrentes na folha de Piracicaba - SP, principalmente aqueles desenvolvidos a partir de rochas das formações Tatuí, Iratí e Corumbataí (membro Serra Alta); esmectita e ilita, nesta ordem, predominam na parte inferior e, caulinita, na parte superior do solum. Estes três minerais podem ser herdados do material de origem, e dentre eles a caulinita, principalmente, pode ainda formar-se por ação do intemperismo. Os autores alertam para o fato de que a interpretação do estádio atual de alteração dos materiais do solo deve ser feita com cautela, pois a mineralogia da rocha sedimentar que originou os solos, pode variar consideravelmente, mesmo a pequenas distâncias. 
Trabalhando com ALISSOLOS CRÔMICOS Argilúvicos na MHCC, Silva et al. ${ }^{2}$ observaram na fração argila predominância de caulinita, juntamente com minerais 2:1, que ocorrem com maior intensidade nos materiais próximos da rocha.

Constatou-se que em grande parte da área de estudo, os solos apresentam alta variabilidade na atividade da argila, porém, observa-se, geralmente, que quando a atividade é baixa, os seus valores são próximos do limite superior da classe, e quando é alta os valores são próximos do limite inferior. Como, os solos são dominantemente de textura média, a atividade da argila pode estar sendo super estimada.

Os solos foram apresentados em mapas, como unidades de mapeamento compostas por unidades taxonômicas puras ou associações complexas, quando não foram possíveis as suas individualizações.

A seguir serão descritas sucintamente as subordens de solos existentes na MHCC.

\section{a) ALISSOLOS CRÔMICOS (AC)}

Esta subordem é a de Segunda maior ocorrência na MHCC, ocupando $20 \%$ da área (Tabela 6 e Figura 11). As unidades taxonômicas foram separadas com base na transição abrupta entre os horizontes A e B ou E e B, profundidade (lépticos ou não), espessura dos horizontes $\mathrm{A}+\mathrm{E}$ (arênicos ou não) e textura dos horizontes $\mathrm{A}$ e Bt. Ocorrem os seguintes subgrupos: ALISSOLOS CRÔMICOS Argilúvicos abrúpticos; ALISSOLOS CRÔMICOS Argilúvicos abrúpticos arênicos; e ALISSOLOS CRÔMICOS Argilúvicos abrúpticos lépticos.

\section{b) ARGISSOLOS VERMELHO-AMARELOS (PVA)}

A subordem PVA ocupa 17,8\% da MHCC (Tabela 6 e Figura 11). As unidades taxonômicas foram separadas com base na saturação por bases do horizonte $\mathrm{Bt}$

\footnotetext{
${ }^{2}$ SILVA, E. F. da; MAFRA, A. L.; COOPER ${ }^{4}$, M.; DEMATTÊ, J. L. I. Caracterização de solos com gradiente textural abrupto desenvolvidos de arenito. Revista Magistra, v. 12, jan./jun. 2000.
} 
(Alumínicos, Distróficos ou Eutróficos), na transição abrupta entre os horizontes A e B ou $\mathrm{E}$ e $\mathrm{B}$, profundidade (lépticos ou não), espessura dos horizontes $\mathrm{A}+\mathrm{E}$ (arênicos ou não) e textura dos horizontes A e Bt. Ocorrem os seguintes subgrupos: ARGISSOLOS VERMELHO-AMARELOS Alumínicos abrúpticos; ARGISSOLOS VERMELHOAMARELOS Alumínicos abrúpticos arênicos; ARGISSOLOS VERMELHOAMARELOS Alumínicos abrúpticos lépticos; ARGISSOLOS VERMELHOAMARELOS Distróficos abrúpticos arênicos; ARGISSOLOS VERMELHOAMARELOS Distróficos abrúpticos lépticos; ARGISSOLOS VERMELHOAMARELOS Distróficos abrúpticos Ta; ARGISSOLOS VERMELHO-AMARELOS Eutróficos abrúpticos; ARGISSOLOS VERMELHO-AMARELOS Eutróficos abrúpticos arênicos; ARGISSOLOS VERMELHO-AMARELOS Eutróficos abrúpticos lépticos;

\section{c) ARGISSOLOS VERMELHOS (PV)}

Apresentam perfis profundos de seqüência $\mathrm{A}, \mathrm{Bt}, \mathrm{C}$ e $\mathrm{R}$, textura média no horizonte A moderado e textura argilosa e muito argilosa no horizonte $\mathrm{Bt}$, com gradiente textural abrupto na maior parte dos solos observados. Ocorre o subgrupo ARGISSOLOS VERMELHOS Eutróficos típicos em $1,2 \%$ da área.

\section{d) LUVISSOLOS CRÔMICOS (TC)}

Estes solos ocorrem em 6,28\% da MHCC (Tabela 6 e Figura 11). As unidades taxonômicas foram separadas com base na profundidade (lépticos ou não), espessura dos horizontes $\mathrm{A}+\mathrm{E}$ (arênicos ou não) e textura dos horizontes $\mathrm{A}$ e Bt. Ocorrem os seguintes subgrupos: LUVISSOLOS CRÔMICOS Pálicos típicos; LUVISSOLOS CRÔMICOS Pálicos arênicos abrúpticos; e LUVISSOLOS CRÔMICOS Órticos abrúpticos.

\section{e) NITOSSOLOS VERMELHOS (NV)}

Os solos NVe e NVet, como mostram a Tabela 6 e Figura 11, ocorrem em pequena percentagem na MHCC (2,2\%), associados entre si e aos CHERNOSSOLOS ARGILÚVICOS e NEOSSOLOS LITÓLICOS originados do diabásio, concentrando-se 
nas cotas mais altas da bacia $(550-600 \mathrm{~m})$ à montante do Córrego do Ceveiro. São considerados solos com alta fertilidade natural e boa aptidão agrícola. Ocorrem os seguintes subgrupos: NITOSSOLOS VERMELHOS Eutróficos argissólicos e NITOSSOLOS VERMELHOS Eutróficos típicos.

\section{f) CHERNOSSOLOS ARGILÚVICOS}

Ocorrem como segundo e terceiro membros das unidades NVet e NVe. Apresentam o subgrupo CHERNOSSOLOS ARGILÚVICOS Órticos típicos.

\section{g) CAMBISSOLOS HÁPLICOS}

A textura varia com o material de origem, aqueles originados de arenitos apresentam textura arenosa e média arenosa, enquanto os originados de siltíto e folhelho da Formação Corumbataí possuem textura média e argilosa. Apresentam argila de atividade alta e baixa, com saturação por bases eutrófico em grande parte e também álico e distrófico. Ocorrem, também, associados aos NEOSSOLOS LITÓLICOS e ocupam $11,1 \%$ da área. Ocorrem os seguintes subgrupos: CAMBISSOLOS HÁPLICOS Ta Alumínicos lépticos; CAMBISSOLOS HÁPliCOS Ta Eutróficos lépticos; CAMBISSOLOS HÁPLICOS Ta Eutróficos típicos; CAMBISSOLOS HÁPLICOS Tb eutróficos lépticos; e CAMBISSOLOS HÁPLICOS Tb Eutróficos típicos.

\section{h) NEOSSOLOS LITÓLICOS (RL)}

Estes solos ocupam 35\% da microbacia (Tabela 6 e Figura 11) e correspondem aos antigos Solos Litólicos. A textura é bastante variada e está diretamente relacionada com a natureza do substrato. Os solos derivados da Formação Corumbataí apresentam dominantemente textura argilosa e média argilosa, os solos formados a partir da Formação Pirambóia geralmente apresentam textura média arenosa ou arenosa, e os originados de diabásio, pouco representativo, apresentam textura argilosa. Em algumas áreas ocorre a presença de pedregosidade, natural ou causada pela aração, em superficie. 
Quimicamente os solos originários da Formação Corumbataí podem ser eutróficos e distróficos, dominantes, ou álicos; apresentam argila de atividade alta (Ta), mais representativos, e baixa $(\mathrm{Tb})$.

Estão presentes em relevo ondulado e suave ondulado e apesar das limitações que apresentam quanto à profundidade e declividade são utilizados em sua grande parte com a cultura de cana-de-açúcar.

Ocorrem os seguintes subgrupos: NEOSSOLOS LITÓLICOS álicos típicos; NEOSSOLOS LITÓLICOS Eutróficos típicos; NEOSSOLOS LITÓLICOS Eutróficos chernossólicos; NEOSSOLOS LITÓLICOS Distróficos típicos álicos; e NEOSSOLOS LITÓLICOS Eutróficos típicos.

\section{i) NEOSSOLOS FLÚVICOS (RU)}

Esta subordem apresenta pequena representatividade na MHCC $(0,9 \%$ da área), como mostram a Tabela 6 e a Figura 11. Correspondem no antigo sistema de classificação aos Solos Aluviais. Estes solos acompanham o dique marginal do córrego do Ceveiro, sendo este dique de largura variável e descontinuo ao longo do curso total. Ocorre o subgrupo NEOSSOLOS FLÚVICOS Tb Eutróficos.

\section{j) GLEISSOLOS HÁPLICOS (GX)}

Pelo próprio regime hídrico a que são submetidos, esses solos apresentam cores quase sempre com mosqueados. A textura varia de arenosa a média argilosa nas camadas superficiais e média arenosa a argilosa nas camadas inferiores a partir de $50 \mathrm{~cm}$ de profundidade. São solos que apresentam fertilidade natural variando de média a baixa, com argila de atividade alta ou baixa, sendo álicos, distróficos e eutróficos.

Os GLEISSOLOS HÁPLICOS estão distribuídos nas várzeas e nas baixadas da MHCC, ocorrendo associados aos NEOSSOLOS FLÚVICOS (Solos Aluviais) e NEOSSOLOS INDIFERENCIADOS (depósitos coluviais), ocupando $6,8 \%$ da área (Tabela 6 e Figura 11), Estes solos apresentam-se saturados durante pelo menos 90 dias do ano o que restringe bastante sua utilização, sendo que nas áreas onde ocorrem estão 
sendo aproveitados com pastagem e alguma cana-de-açúcar. Ocorre o subgrupo GLEISSOLOS HÁPLICOS Indiscriminados.

\section{k) NEOSSOLOS INDIFERENCIADOS*}

Devido à degradação acelerada de algumas vertentes da microbacia, por erosão, depósitos coluviais recentes com estratificação paralela nítida podem ocorrer localmente no sopé destas, soterrando NEOSSOLOS FLÚVICOS, GLEISSOLOS HÁPLICOS, NEOSSOLOS LITÓLICOS e solos com horizonte B textural. Este material possui textura, atividade de argila e saturação de base indiscriminada, variando com o solo que deu origem.

*Sugere-se a criação dessa subordem.

\subsubsection{Equivalência (correlação) dos solos da microbacia no Sistema Brasileiro de Classificação de solos}

Este trabalho não teve por finalidade estudar a gênese e classificação dos solos da microbacia hidrográfica do Córrego do Ceveiro, trata-se de um trabalho sobre cartografia de solos e qualidade de mapeamento, mas, que pela necessidade de classificação dos solos, procurou-se enquadrar os solos no novo Sistema Brasileiro de Classificação de Solos (Embrapa, 1999).

$\mathrm{A}$ área de estudo, devido ao tipo de material de origem e topografia (Material e métodos), apresenta uma grande variabilidade de solos, tanto nas características morfológicas: profundidade do solum, espessura do horizonte $\mathrm{A}$ e horizontes diagnósticos, como nos atributos físico-químicos desses solos (a ser discutido posteriormente), principalmente atividade da argila, saturação por bases e saturação por alumínio, que são atributos diferenciadores de classes de solos já no $1^{\circ}$ nível categórico (Ordem de solos).

As primeiras dificuldades foram separar no campo os solos com horizonte B textural de acordo com a atividade da argila, saturação por bases e saturação por alumínio no $1^{\circ}$ nível categórico (ALISSOLOS, ARGISSOLOS e LUVISSOLOS). Em 
várias unidades de mapeamento, essas ordens de solos ocorrem associadas: $\mathrm{ACt} 2, \mathrm{ACt} 3$, ACtq, ACt11, PVAel2, PVAel3, TCp e TCpq, por serem de difícil ou impossível separação, formam associação complexa.

Este trabalho, devido ao detalhamento, proporcionou subsidiar o desenvolvimento do Sistema Brasileiro de Classificação de Solos (Embrapa, 1999), e os dados dos perfis examinados, evidenciam que há necessidade de criar as seguintes classes:

Ao nivel de SUBORDEM:

- NEOSSOLOS INDIFERENCIADOS - Criar INDIFERENCIADOS para solos formados por material coluvionar, originados por erosão, escorregamentos, etc. Utilizado nas unidades de mapeamento GX1, GX2, GX3 e RUbe.

Ao nível de GRANDE GRUPO:

- ARGISSOLOS VERMELHO-AMARELOS Ta Distróficos - acrescentar Ta Distróficos para solos PVA que apresentam argila de atividade alta e são Distróficos. Utilizado na unidade de mapeamento PVAdv

- NEOSSOLOS LITÓLICOS Álicos - Criar Álicos para solos que apresentam saturação por alumínio $>50 \%$.

Ao nivel de SUBGRUPO:

- ALISSOLOS CRÔMICOS Argilúvicos abrúpticos arênicos - acrescentar arênicos (símbolo q) para solos com horizontes $\mathrm{A}+\mathrm{E}$ arenosos $>50 \mathrm{~cm}$ na unidade de mapeamento ACtq.

- ALISSOLOS CRÔMICOS Argilúvicos abrúpticos lépticos - acrescentar lépticos para solos pouco profundos (símbolo I - adaptado) nas unidades de mapeamento ACtl1, ACt12 e PVAel2. 
- ARGISSOLOS VERMELHO-AMARELOS Alumínicos abrúpticos acrescentar abrúpticos para solos com mudança textural abrupta nas unidades de mapeamento ACt3 (associado) e PVAa2.

- ARGISSOLOS VERMELHO-AMARELOS Alumínicos abrúpticos arênicos - acrescentar abrúpticos para solos com mudança textural abrupta e arênicos (símbolo q) para solos com horizontes $\mathrm{A}+\mathrm{E}$ arenoso $>50 \mathrm{~cm}$ na unidade de mapeamento ACtq (associado).

- ARGISSOLOS VERMELHO-AMARELOS Alumínicos abrúpticos lépticos acrescentar abrúpticos para solos com mudança textural abrupta e lépticos para solos pouco profundos (símbolo 1 - adaptado) nas unidades de mapeamento ACtl1 (associado), PVAal1 e PVAal2.

- ARGISSOLOS VERMELHO-AMARELOS Distróficos abrúpticos arênicos - acrescentar arênicos (símbolo q) para solos com horizontes $\mathrm{A}+\mathrm{E}$ arenosos > $50 \mathrm{~cm}$ na unidade de mapeamento PVAdq.

- ARGISSOLOS VERMELHO-AMARELOS Distróficos abrúpticos lépticos acrescentar lépticos para solos pouco profundos (símbolo I - adaptado) na unidade de mapeamento PVAdl

- ARGISSOLOS VERMELHO-AMARELOS Eutróficos abrúpticos arênicos acrescentar arênicos (símbolo q) para solos com horizonte $A$ arenosos $>50$ $\mathrm{cm}$ nas unidades de mapeamento TCpq (associado) e PVAeq.

- ARGISSOLOS VERMELHO-AMARELOS Eutróficos abrúpticos lépticos acrescentar lépticos para solos pouco profundos (símbolo I - adaptado) nas unidades de mapeamento PVAel1, PVAel2, PVAel3 e PVAel4

- LUVISSOLOS CRÔMICOS Pálicos arênicos abrúpticos - acrescentar abrúpticos para solos com mudança textural abrupta e arênicos (símbolo q) para solos com horizontes $\mathrm{A}+\mathrm{E}$ arenosos $>50 \mathrm{~cm}$ na unidade de mapeamento TCpq. 
- LUVISSOLOS CRÔMICOS Órticos abrúpticos - acrescentar abrúpticos para solos com mudança textural abrupta nas unidades de mapeamento TCol1 e TCol2.

- NITOSSOLOS VERMELHOS Eutróficos argissólicos - acrescentar argissólicos (símbolo t) para solos com incremento de argila entre o horizonte A e o horizonte $\mathrm{B}$ nítico nas unidades de mapeamento NVet e NVe (associado).

\subsection{Precisão dos atributos de solos}

Os atributos do solo, nos três mapas, foram avaliados para as unidades de mapeamento, utilizando-se os seguintes parâmetros estatísticos básicos: média, valor máximo, valor mínimo, coeficiente de variação (CV\%), intervalo de confiança da média e índice de uniformidade. Os resultados para cada mapa de solos, utilizando-se a amostragem do levantamento detalhado de solos-2000, são apresentados nos Anexos A, B e C. Nas Tabelas 7, 9 e 10 são apresentados um resumo dos atributos do solo com a média, coeficiente de variação e índice de uniformidade para as unidades com três ou mais observações; para aquelas com duas observações é apresentada apenas a média e as unidades com apenas uma observação é representada pela sua amostra.

\subsubsection{Mapa detalhado de solos-2000}

A análise da precisão dos atributos de solos do mapa detalhado de solos-2000 foi baseada nas informações do Anexo A e Tabela 7.

Os dados evidenciam a grande variabilidade interna nas unidades de mapeamento, indicada pelos altos valores de CV\% - normalmente acima de $50 \%$ e pelo limite de confiança, dos atributos areia grossa, fósforo, matéria orgânica, as bases $(\mathrm{Ca}$, $\mathrm{Mg}$ e K), atividade da argila e saturação por alumínio. Nota-se também a baixa variabilidade dos valores de $\mathrm{pH}$ com $\mathrm{CV} \%$ quase sempre inferiores a $10 \%$. Estes baixos valores de $\mathrm{CV} \%$ para os valores de $\mathrm{pH}$, são explicados por ser o $\mathrm{pH}$ uma medida de 
Tabela 7- Resumo dos atributos do solo das unidades de mapeamento do mapa detalhado-2000.

\begin{tabular}{|c|c|c|c|c|c|c|c|c|c|c|c|c|c|c|c|c|c|}
\hline nMapa & Hor & Estat. & Obs. & Areia & Silte & Arg. & $\mathrm{pH}$ & MO & $\mathrm{P}$ & & CTC & Targ & $\mathrm{V}$ & $\mathrm{m}$ & IM1 & IM2 & $\mathbb{1 M 3}$ \\
\hline & & & & & $\mathrm{g} \mathrm{kg}^{-1}$ & & $\mathrm{CaCl}_{2}$ & $\mathrm{~g} \mathrm{~kg}^{-1}$ & $\mathrm{mgkg}^{-1}$ & $--\mathrm{mr}$ & molc.k & $\mathrm{gg}^{-1}-\ldots$ &.$---\%$ & 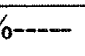 & $\ldots$ & $-\%$ & \\
\hline \multirow[t]{6}{*}{ ACt1 } & A & MĖDIA & 6 & 830 & 87 & 83 & 4.6 & 9 & 22 & 23 & 50 & 336 & 47 & 22 & & & \\
\hline & & & 6 & 4 & 19 & 38 & 12 & 30 & 101 & 78 & 31 & 61 & 69 & 101 & 45 & 51 & 46 \\
\hline & & UNIF \% & 6 & 91 & 70 & 42 & 4 & 45 & 70 & 20 & 48 & 32 & -47 & -2 & 30 & 30 & 19 \\
\hline & B & MÉDIA & 6 & 685 & 88 & 227 & 3.9 & 8 & 2 & 19 & 77 & 250 & 26 & 62 & & & \\
\hline & & $\mathrm{CV} \%$ & 6 & 5 & 26 & 15 & 4.5 & 40 & 31 & 37 & 25 & 24 & 41 & 32 & 31 & 34 & 20 \\
\hline & & UNIF \% & 6 & 87 & 57 & 59 & 66 & 37 & 86 & 49 & 36 & 62 & 22 & 62 & 49 & 47 & 48 \\
\hline \multirow[t]{6}{*}{$\mathrm{ACt} 2$} & A & MÉDIA & 81 & 788 & 99 & 113 & 4.3 & 14 & 5 & 18 & 52 & 208 & 33 & 29 & & & \\
\hline & & $\mathrm{CV} \%$ & 81 & 9 & 32 & 46 & 11 & 63 & 97 & 66 & 33 & 93 & 39 & 71 & 81 & 50 & \\
\hline & & UNIF \% & 81 & 76 & 50 & 31 & 13 & -16 & 71 & 3 & 44 & -5 & 16 & 28 & 17 & 33 & 24 \\
\hline & B & MÉDIA & 82 & 607 & 106 & 287 & 4.2 & 11 & 3 & 29 & 86 & 219 & 36 & 48 & & & \\
\hline & & $\mathrm{CV} \%$ & 82 & 13 & 42 & 23 & 11 & 71 & 78 & & 6 & 63 & & 60 & 61 & 47 & 36 \\
\hline & & UNIF \% & 82 & 68 & 31 & 38 & 16 & -11 & 66 & & 34 & -2 & -8 & 9 & 20 & 27 & 21 \\
\hline \multirow[t]{2}{*}{$\mathrm{ACt} 3$} & A & Amostra & 1 & 710 & 110 & 180 & 3.8 & 10 & 1 & & 87 & 335 & 19 & 61 & & & \\
\hline & B & Amostra & 1 & 590 & 120 & 290 & 3.9 & 1 & 2 & & 89 & 217 & 33 & 60 & & & \\
\hline \multirow[t]{6}{*}{$\mathrm{ACt} 4$} & A & MÉDIA & 3 & 487 & 260 & 253 & 4.8 & 18 & 9 & 4 & 82 & 122 & & 14 & & & \\
\hline & & $\mathrm{CV} \%$ & 3 & 30 & 18 & 41 & 16 & 53 & 100 & & 62 & 76 & & 101 & 62 & 62 & \\
\hline & & UNIF \% & 3 & 23 & 72 & 39 & -2 & & 71 & & -4 & 14 & & & 13 & 17 & 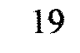 \\
\hline & B & MÉDIA & 3 & 313 & 283 & 403 & 4.0 & 9 & & 26 & 123 & 255 & & 47 & & & \\
\hline & & $\mathrm{CV} \%$ & 3 & 43 & 45 & 12 & 0.0 & 59 & 0 & 15 & 23 & 37 & & 8 & 48 & 43 & \\
\hline & & UNIF \% & 3 & -9 & 26 & $6 ?$ & 100 & 7 & 100 & 80 & 42 & 40 & & -3 & 37 & 38 & \\
\hline \multirow[t]{6}{*}{ ACtq } & A & MÉDIA & 16 & 834 & 83 & 8 & 4.3 & 14 & 24 & 1 & 47 & 243 & & 3 & & & \\
\hline & & CV\% & 16 & 10 & 30 & 79 & 7.2 & 8 & 188 & 69 & 42 & 108 & & & 53 & 62 & \\
\hline & & UNIF \% & 16 & 75 & 53 & -19 & 42 & -60 & 44 & 3 & 29 & -21 & -14 & 4 & 29 & 24 & \\
\hline & B & MÉDIA & 16 & 680 & 80 & 243 & 4.2 & 1 & 2 & 30 & 87 & 228 & 38 & 44 & & & \\
\hline & & CV\% & 16 & 9 & 33 & 20 & 11 & 9 & 70 & 52 & 24 & 57 & 64 & 7 & 43 & 47 & 8 \\
\hline & & UNIF \% & 16 & 78 & 45 & $4 c$ & 19 & -52 & 69 & 29 & 39 & 7 & -21 & 15 & 28 & 27 & \\
\hline \multirow[t]{6}{*}{ ACtl1 } & A & MÉDIA & 10 & 806 & 84 & 110 & 4.1 & 16 & 6 & 20 & 66 & 278 & 30 & 37 & & & \\
\hline & & CV \% & 10 & 5 & 22 & 30 & 5.8 & 72 & 127 & 88 & 40 & 105 & 61 & 3 & 50 & & \\
\hline & & UNIF \% & 10 & 88 & 66 & 55 & 54 & -32 & 63 & 11 & 33 & -19 & -29 & 63 & 31 & 27 & \\
\hline & B & MÉDIA & 11 & 639 & 136 & 225 & 4.0 & 15 & 2 & 27 & 110 & 331 & 24 & 64 & & & \\
\hline & & CV\% & 11 & 28 & 80 & 43 & 7.5 & 9 & 46 & 94 & 29 & 62 & 81 & 3 & 67 & 58 & \\
\hline & & UNIF \% & 11 & 29 & -31 & -14 & 43 & -48 & 80 & -28 & 27 & -1 & -53 & 5 & 8 & 8 & \\
\hline \multirow[t]{6}{*}{$\mathrm{ACt} 12$} & A & MÉDIA & 3 & 847 & 73 & 80 & 4.1 & 10 & 4 & 7 & 44 & 184 & 18 & 36 & & & \\
\hline & & $\mathrm{CV} \%$ & 3 & 10 & 69 & 50 & 3.7 & 107 & 42 & 56 & 56 & 134 & 52 & & 51 & 1 & \\
\hline & & UNIF \% & 3 & 75 & -8 & 2 & 70 & $-9 c$ & 88 & 43 & 6 & -51 & -10 & 12 & 25 & 15 & \\
\hline & B & MÉDIA & 3 & 483 & 160 & 357 & 4.0 & 11 & 3 & 26 & 123 & 250 & 23 & 68 & & & \\
\hline & & $\mathrm{CV} \%$ & 3 & 21 & 22 & 20 & 2.9 & 90 & 22 & 17 & 31 & 62 & 40 & 21 & 30 & 35 & \\
\hline & & UNIF \% & 3 & 46 & 64 & 47 & 78 & -41 & 91 & 77 & 21 & 0 & 25 & 76 & 50 & 44 & \\
\hline \multirow[t]{6}{*}{ PVAal } & A & MEEDIA & 4 & 755 & 115 & 130 & 4.2 & 19 & 4 & 17 & 44 & 55 & 39 & 27 & & & \\
\hline & & $\mathrm{CV} \%$ & 4 & 11 & 61 & 37 & 7. & 38 & 0 & 40 & 30 & 200 & 38 & & 41 & 50 & \\
\hline & & UNIF \% & 4 & 72 & 4 & 45 & 44 & 30 & 100 & 59 & 49 & -126 & 20 & 50 & 39 & 30 & \\
\hline & B & MÉDIA & 4 & 495 & 90 & 415 & 4.2 & 20 & 3 & 32 & 84 & 79 & 37 & 47 & & & \\
\hline & & $\mathrm{CV} \%$ & 4 & 21 & 33 & 18 & 3.1 & 44 & 52 & 63 & 26 & 92 & 40 & 68 & 35 & 38 & \\
\hline & & UNIF \% & 4 & 48 & 46 & 51 & 16 & 31 & 77 & 14 & 33 & -4 & 25 & 20 & 44 & 40 & \\
\hline
\end{tabular}


Tabela 7- Continuacão.

\begin{tabular}{rrrrrrrrrrrr}
\hline UnMapa Hor Estat. Obs. Areia Silte Arg. & pH & MO & P & S & CTC & Targ & $\mathrm{V}$ & $\mathrm{m}$ & IM1 & IM2 IM3 \\
\hline
\end{tabular}

$\begin{array}{llllllllllllll}\text { PVAel A Amostra } & 1 & 820 & 120 & 60 & 4.3 & 15 & 2 & 9 & 27 & 0 & 32 & 32\end{array}$

$\begin{array}{llllllllllllll}\text { B Amostra } & 1 & 690 & 110 & 200 & 4.8 & 10 & 3 & 49 & 67 & 205 & 73 & 2\end{array}$

$\begin{array}{lllllllllllllll}\text { PVAe2 } & \text { A } & \text { Amostra } & 1 & 780 & 120 & 100 & 3.8 & 13 & 28 & 14 & 51 & 168 & 27 & 42\end{array}$

$\begin{array}{llllllllllllll}\text { B Amostra } & 1 & 480 & 130 & 390 & 4.8 & 13 & 4 & 39 & 60 & 66 & 65 & 3\end{array}$

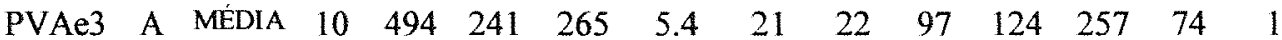
$\begin{array}{llllllllllllllll}\mathrm{CV} \% & 10 & 34 & 29 & 43 & 13 & 18 & 96 & 69 & 50 & 88 & 25 & 169 & 66 & 64 & 60\end{array}$ $\begin{array}{llllllllllllllll}\text { UNIF \% } & 10 & 11 & 55 & 36 & -1 & 67 & 72 & 30 & 15 & 1 & 47 & -70 & 15 & 19 & 4\end{array}$

$\begin{array}{llllllllllllll}\text { B } & \text { MÉDIA } & 10 & 343 & 183 & 474 & 4.9 & 17 & 3 & 67 & 113 & 146 & 61 & 12\end{array}$ $\begin{array}{llllllllllllllll}\mathrm{CV} \% & 10 & 36 & 27 & 22 & 16 & 32 & 68 & 40 & 25 & 32 & 33 & 138 & 66 & 61 & 43\end{array}$ $\begin{array}{llllllllllllllll}\text { UNIF \% } & 10 & 10 & 55 & 40 & -20 & 50 & 70 & 46 & 36 & 49 & 38 & -63 & 12 & 14 & 12\end{array}$

$\begin{array}{llllllllllllll}\text { PVAdq A } & \text { MÉDIA } & 4 & 810 & 80 & 110 & 4.0 & 10 & 3 & 11 & 38 & 133 & 28 & 41\end{array}$ $\begin{array}{lllllllllllll}\mathrm{CV} \% & 4 & 4 & 20 & 31 & 4.2 & 40 & 38 & 53 & 28 & 78 & 34 & 58\end{array}$ $\begin{array}{lllllllllllll}\text { UNIF \% } & 4 & 89 & 68 & 53 & 66 & 27 & 89 & 47 & 53 & 12 & 28 & 42\end{array}$

$\begin{array}{lll}40 & 45 & 34\end{array}$

$\begin{array}{llllllllllllll}\text { B MEDIA } & 4 & 645 & 60 & 295 & 4.3 & 8 & 2 & 24 & 55 & 103 & 45 & 32\end{array}$

$\begin{array}{llllllllllllllll}\mathrm{CV} \% & 4 & 15 & 27 & 36 & 12 & 56 & 56 & 45 & 47 & 81 & 23 & 69 & 48 & 54 & 37\end{array}$

$\begin{array}{llllllllllllllll}\text { UNIF \% } & 4 & 63 & 55 & 5 & 12 & 12 & 76 & 39 & -21 & -31 & 57 & 18 & 21 & 18 & 19\end{array}$

$\begin{array}{lllllllllllllll}\text { PVAdv A Amostra } & 1 & 510 & 260 & 230 & 5.8 & 13 & 14 & 70 & 110 & 331 & 64 & 0\end{array}$

$\begin{array}{llllllllllllll}\text { B Amostra } & 1 & 190 & 170 & 640 & 4.9 & 18 & 2 & 85 & 195 & 232 & 44 & 1\end{array}$

$\begin{array}{lllllllllllllll}\text { PVAeq } & \text { A } & \text { MÉDIA } & 4 & 820 & 100 & 80 & 4.2 & 13 & 4 & 10 & 29 & 20 & 35 & 30\end{array}$

$\begin{array}{llllllllllllllll}\mathrm{CV} \% & 4 & 8 & 57 & 35 & 15 & 49 & 56 & 71 & 34 & 200 & 58 & 117 & 51 & 58 & 70\end{array}$

$\begin{array}{llllllllllllllll}\text { UNIF } \% & 4 & 79 & 11 & 47 & -20 & 10 & 84 & 28 & 43 & -126 & -22 & -18 & 25 & 23 & -7\end{array}$

$\begin{array}{llllllllllllll}\text { B } & \text { MÉDIA } & 4 & 653 & 95 & 253 & 4.3 & 12 & 3 & 29 & 54 & 97 & 52 & 21\end{array}$

$\begin{array}{llllllllllllllll}\mathrm{CV} \% & 4 & 15 & 60 & 16 & 6.8 & 87 & 69 & 42 & 16 & 81 & 30 & 100 & 45 & 45 & 40\end{array}$

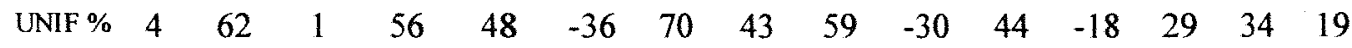

$\begin{array}{llllllllllllll}\text { PVAal1 A } & \text { MEDIA } & 2 & 730 & 150 & 120 & 4.1 & 10 & 2 & 11 & 37 & 100 & 31 & 34\end{array}$

$\begin{array}{llllllllllllll}\text { B MÉDIA } & 2 & 420 & 180 & 400 & 4.2 & 5 & 2 & 29 & 81 & 171 & 37 & 46\end{array}$

$\begin{array}{lllllllllllllll}\text { PVAal2 A Amostra } & 1 & 620 & 220 & 160 & 3.8 & 23 & 6 & 7 & 55 & 0 & 13 & 75\end{array}$

$\begin{array}{llllllllllllll}\text { B Amostra } & 1 & 380 & 190 & 430 & 3.9 & 23 & 2 & 30 & 106 & 106 & 28 & 56\end{array}$

$\begin{array}{lllllllllllllll}\text { PVAel1 A Amostra } & 1 & 490 & 240 & 270 & 4.9 & 20 & 4 & 51 & 79 & 99 & 65 & 0\end{array}$

$\begin{array}{llllllllllllll}\text { B Amostra } & 1 & 270 & 250 & 480 & 5.3 & 18 & 4 & 75 & 96 & 101 & 78 & 0\end{array}$

$\begin{array}{llllllllllllll}\text { PVAel2 A } & \text { MÉDIA } & 3 & 420 & 330 & 250 & 4.3 & 26 & 5 & 38 & 76 & 40 & 49 & 21\end{array}$ $\begin{array}{llllllllllllllll}\mathrm{CV} \% & 3 & 25 & 15 & 22 & 4.7 & 34 & 11 & 53 & 26 & 156 & 41 & 96 & 37 & 43 & 57\end{array}$ $\begin{array}{llllllllllllllll}\text { UNIF \% } & 3 & 35 & 76 & 67 & 63 & 38 & 97 & 47 & 56 & -76 & 12 & 4 & 46 & 40 & 7\end{array}$

$\begin{array}{llllllllllllll}\text { B } & \text { MÉDIA } & 3 & 293 & 363 & 343 & 4.1 & 11 & 2 & 46 & 93 & 180 & 51 & 29\end{array}$ $\begin{array}{llllllllllllllll}\mathrm{CV} \% & 3 & 12 & 10 & 15 & 6.5 & 54 & 49 & 14 & 26 & 42 & 24 & 39 & 27 & 30 & 22\end{array}$ $\begin{array}{llllllllllllllll}\text { UNIF \% } & 3 & 70 & 83 & 61 & 51 & 15 & 78 & 81 & 35 & 33 & 55 & 54 & 58 & 52 & 45\end{array}$

$\begin{array}{lllllllllllllll}\text { PVAel3 A Amostra } & 1 & 580 & 260 & 160 & 4.5 & 10 & 8 & 25 & 59 & 206 & 42 & 11\end{array}$

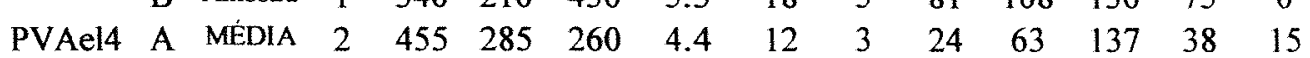

$\begin{array}{llllllllllllll}\text { B } & \text { MÉDIA } & 2 & 135 & 215 & 650 & 4.8 & 11 & 2 & 72 & 112 & 130 & 67 & 4\end{array}$

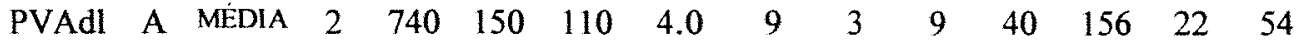

$\begin{array}{llllllllllllll}\text { B } & \text { MÉDIA } & 2 & 520 & 195 & 285 & 4.5 & 11 & 4 & 36 & 80 & 183 & 47 & 14\end{array}$ 
Tabela 7-Continuação.

\begin{tabular}{|c|c|c|c|c|c|c|c|c|c|c|c|c|c|c|c|c|c|}
\hline & & stat. & bs. & eia & Silte & Arg. & $\mathrm{pH}$ & MO & & & TTC & Targ & & $\mathrm{m}$ & MI & IM2 & IM3 \\
\hline & & & & & & & & & & & & $g^{-1}-$ & & & & $\%$ & \\
\hline \multirow[t]{6}{*}{ PVe } & $\mathrm{A}$ & MÉDIA & 3 & 580 & 203 & 217 & 4.5 & 18 & 5 & 35 & 75 & 126 & 46 & 14 & & & \\
\hline & & $\%$ & 3 & 29 & 40 & 40 & 10 & 14 & 76 & 50 & 24 & 46 & 30 & 133 & 48 & 46 & 46 \\
\hline & & UNIF \% & 3 & 26 & 37 & 40 & 17 & 74 & 78 & 49 & 60 & 48 & 36 & -34 & 39 & 43 & 19 \\
\hline & B & MÉDIA & 3 & 340 & 157 & 503 & 5.3 & 14 & 4 & 67 & 85 & 101 & 78 & 0 & & & \\
\hline & & $\mathrm{CV} \%$ & 3 & 37 & 33 & 22 & 3.9 & 36 & 25 & & 16 & 61 & 10 & & 34 & 29 & 26 \\
\hline & & UNIF \% & 3 & 7 & 46 & 41 & 70 & 44 & 89 & 69 & 58 & 0 & 81 & 100 & 53 & 52 & 38 \\
\hline \multirow[t]{2}{*}{ TCp } & A & MÉDIA & 2 & 480 & 155 & 365 & 4.8 & 14 & 9 & 77 & 118 & 230 & & 1 & & & \\
\hline & B & ÉDIA & 2 & 420 & 105 & 475 & 5.6 & 4 & 6 & & 146 & 278 & & 0 & & & \\
\hline \multirow[t]{6}{*}{ TCpq } & A & MEEDIA & 3 & 737 & 157 & 107 & 5.0 & 17 & 309 & 68 & 95 & 429 & & 6 & & & \\
\hline & & $\mathrm{CV} \%$ & 3 & 3 & 16 & 29 & 11 & 71 & 130 & 96 & 72 & 57 & 0 & 173 & 57 & 70 & 50 \\
\hline & & UNIF \% & 3 & 93 & 75 & 57 & 13 & -31 & 62 & & -22 & 36 & & -74 & 29 & 20 & 21 \\
\hline & B & MÉDIA & 3 & 573 & 127 & 300 & 4.8 & 8 & 17 & 48 & 79 & 205 & 8 & 10 & & & \\
\hline & & $\mathrm{CV} \%$ & 3 & 13 & 24 & 19 & 14 & 60 & 153 & 60 & 27 & 37 & & 173 & 48 & 52 & 46 \\
\hline & & UNIF \% & 3 & 67 & 60 & 50 & -4.7 & 5 & 33 & 18 & 30 & 40 & 33 & -104 & 25 & 26 & 14 \\
\hline \multirow[t]{2}{*}{ TColl } & A & Amostra & 1 & 700 & 180 & 120 & 4.8 & 5 & 13 & & 56 & 358 & & 4 & & & \\
\hline & B & Amostra & 1 & 580 & 70 & 350 & 5.1 & 5 & & & 97 & 240 & & & & & \\
\hline \multirow[t]{6}{*}{ TCol2 } & A & MÉDIA & 6 & 448 & 312 & 240 & 4.9 & 19 & 10 & 5 & 112 & 265 & & 4 & & & \\
\hline & & CV\% & 6 & 35 & 32 & 27 & 11 & 39 & 69 & 62 & 43 & 63 & 5 & 220 & 57 & 62 & 62 \\
\hline & & UNIF \% & 6 & 9 & 50 & 59 & 16 & 28 & 80 & & 27 & 29 & 7 & -122 & 25 & 22 & 4 \\
\hline & B & MEDIA & 6 & 342 & 248 & 410 & 4.6 & 12 & 7 & & 137 & 268 & & 23 & & & \\
\hline & & $\mathrm{CV} \%$ & 6 & 52 & 30 & 36 & 16 & 40 & 143 & & 36 & 44 & & 88 & 54 & 59 & 44 \\
\hline & & UNIF \% & 6 & -31 & 50 & 5 & -18 & 37 & 38 & $2 ?$ & 8 & 29 & 13 & -4 & 14 & 10 & 2 \\
\hline \multirow[t]{2}{*}{ NVet } & A & Amostra & 1 & 640 & 140 & 22 & 4.4 & 15 & & 2 & 62 & 103 & & 14 & & & \\
\hline & B & Amostra & 1 & 360 & 150 & 49 & 5.2 & 15 & 3 & & 58 & 39 & & & & & \\
\hline \multirow[t]{6}{*}{ NVe } & A & MÉDIA & 3 & 317 & 207 & 477 & 5.4 & 20 & 44 & 7 & 114 & 125 & & & & & \\
\hline & & $\mathrm{CV} \%$ & 3 & 53 & 27 & 33 & 7.4 & 79 & 153 & 55 & 40 & 22 & & 0 & 43 & 39 & 21 \\
\hline & & UNIF \% & 3 & -37 & 58 & 51 & 41 & -45 & 55 & 4 & 33 & 75 & & 100 & 35 & 43 & 43 \\
\hline & B & MÉDIA & 3 & 250 & 133 & 617 & 5.8 & 13 & 7 & & 94 & 100 & & & & & \\
\hline & & $\mathrm{CV} \%$ & 3 & 38 & 11 & 13 & 3.4 & 54 & 52 & & 29 & 59 & & & 33 & 32 & 22 \\
\hline & & UNIF \% & 3 & 4 & 81 & 65 & 74 & 16 & 77 & 4 & 25 & 4 & & 100 & 51 & 46 & 39 \\
\hline \multirow[t]{2}{*}{ CXve } & A & Amostra & 1 & 460 & 330 & 210 & 4.5 & 13 & 3 & 7 & 103 & 326 & & 4 & & & \\
\hline & B & Amostra & 1 & 400 & 390 & 210 & 4.6 & 5 & 3 & 9 & 120 & 511 & & & & & \\
\hline \multirow[t]{2}{*}{ CXva } & A & Amostra & 1 & 470 & 280 & 250 & 4.0 & 1 & 3 & & 133 & 425 & 29 & & & & \\
\hline & BC & Amostra & 1 & 430 & 340 & 230 & 3.7 & 10 & 3 & & 149 & 536 & 1 & & & & \\
\hline \multirow[t]{6}{*}{ CXvbed } & A & MÉDIA & 12 & 297 & 326 & 378 & 4.8 & 17 & 19 & 7 & 151 & 266 & 5 & 1 & & & \\
\hline & & $\mathrm{CV} \%$ & 12 & 48 & 23 & 26 & 13 & 50 & 106 & 4 & 35 & 47 & 38 & 232 & 60 & 69 & 6 \\
\hline & & UNIF \% & 12 & -23 & 64 & 61 & -5 & 8 & 69 & 5 & 42 & 47 & & -134 & 18 & 19 & - \\
\hline & B & MÉDIA & 12 & 303 & 277 & 420 & 4.6 & 1. & 16 & 74 & 147 & 259 & 53 & 16 & & & \\
\hline & & CV\% & 12 & 47 & 24 & 28 & 10 & 4 & 156 & 45 & 39 & 51 & & 133 & 63 & 66 & 4 \\
\hline & & UNIF \% & 12 & -18 & 61 & 25 & 26 & 28 & 32 & 38 & 1 & 18 & 29 & -56 & 0 & -7 & \\
\hline \multirow[t]{2}{*}{ GXI } & A & & 1 & 840 & 80 & 80 & 4.2 & 3 & 3 & 2 & 72 & 801 & 36 & 19 & & & \\
\hline & $\mathrm{C}$ & Amostra & 1 & 720 & 140 & 140 & 3. & 6 & & & 86 & 499 & & 4 & & & \\
\hline \multirow[t]{2}{*}{ GX2 } & A & MÉDIA & 2 & 415 & 290 & 295 & 4.2 & 18 & 8 & 30 & 79 & 99 & 3 & 23 & & & \\
\hline & C & MĖDIA & 2 & 315 & 245 & 440 & 4.0 & 1 & & 31 & 81 & 148 & 38 & 41 & & & \\
\hline
\end{tabular}


Tabela 7-Continuação.

\begin{tabular}{|c|c|c|c|c|c|c|c|c|c|c|c|c|c|c|c|c|c|}
\hline & for & Estat. & Obs. & Areia & Silte & Arg. & $\mathrm{pH}$ & MO & & & & Targ & $V$ & $\mathrm{~m}$ & M1 & IM2 & IM3 \\
\hline & & & & & & & $\mathrm{CaCl}$ & & & & & & & & & & \\
\hline \multirow[t]{3}{*}{$\mathrm{GX3}$} & A & MÉDIA & 4 & 335 & 393 & 273 & 4.4 & 17 & 14 & 38 & 114 & 275 & 39 & 16 & & & \\
\hline & & $\mathrm{CV} \%$ & 4 & 43 & 32 & 14 & 12 & 24 & 54 & 37 & 31 & 70 & 63 & 81 & 38 & 42 & 45 \\
\hline & & UNIF \% & 4 & -10 & 49 & 79 & 0 & 57 & 84 & 6 & 48 & 21 & -35 & 19 & 36 & 35 & 12 \\
\hline \multirow[t]{3}{*}{ GX3 } & $\mathrm{C}$ & MÉDIA & 4 & 218 & 283 & 500 & 3.8 & 9 & 3 & 21 & 130 & 232 & 16 & 68 & & & \\
\hline & & CV\% & 4 & 56 & 24 & 29 & 3.3 & 58 & 18 & & 44 & 72 & 24 & 27 & 46 & 41 & 35 \\
\hline & & UNIF \% & 4 & -42 & 60 & 23 & 75 & 9 & 92 & & -12 & -16 & 55 & 69 & 30 & 27 & 15 \\
\hline \multirow[t]{2}{*}{ RLa } & A & MĖDIA & 2 & 610 & 210 & 180 & 3.9 & 18 & 18 & 15 & 73 & 144 & 20 & 55 & & & \\
\hline & CR & MÉDIA & 2 & 565 & 235 & 200 & 3.9 & 14 & 13 & 18 & 73 & 184 & 25 & 55 & & & \\
\hline \multirow[t]{2}{*}{ RLd1 } & $\mathrm{AC}$ & Amostra & 1 & 350 & 410 & 240 & 4.6 & 20 & & 2 & 59 & 27 & 4 & & & & \\
\hline & $\mathrm{CR}$ & Amostra & 1 & 320 & 470 & 210 & 4.6 & 5 & & & 32 & 90 & & 7 & & & \\
\hline \multirow[t]{2}{*}{ RLd2 } & A & Amostra & 1 & 130 & 330 & 540 & 3.9 & 23 & & 38 & 116 & 103 & 33 & 53 & & & \\
\hline & $\mathrm{C}$ & Amostra & 1 & 130 & 310 & 560 & 3.8 & 18 & & & 122 & 133 & 34 & 53 & & & \\
\hline \multirow[t]{6}{*}{ RLel } & A & MÉDIA & 13 & 386 & 317 & 297 & 4.6 & 18 & 24 & 68 & 106 & 188 & 61 & 9 & & & \\
\hline & & $\mathrm{CV} \%$ & 13 & 39 & 37 & 25 & 8.8 & 33 & 120 & 78 & 52 & 71 & 25 & 136 & 57 & 64 & 49 \\
\hline & & UNIF \% & 13 & -1 & 42 & 62 & 30 & 40 & 65 & 21 & 13 & 20 & & -37 & 23 & 18 & 15 \\
\hline & $\mathrm{CR}$ & MĖDIA & 12 & 359 & 325 & 316 & 4.6 & 15 & 20 & & 106 & 214 & 66 & 12 & & & \\
\hline & & $\mathrm{CV} \%$ & 12 & 35 & 27 & 33 & 8.7 & 27 & 128 & 6 & 40 & 55 & 26 & 125 & 55 & 60 & 46 \\
\hline & & UNIF \% & 12 & 12 & 56 & 11 & 34 & 58 & 44 & 13 & -2 & 11 & 51 & -48 & 19 & 13 & 6 \\
\hline \multirow[t]{6}{*}{ RLe2 } & A & MÉDIA & 8 & 205 & 366 & 429 & 4.8 & 19 & 14 & 7. & 134 & 195 & 5 & 9 & & & \\
\hline & & $\mathrm{CV} \%$ & 8 & 27 & 16 & 19 & 13 & 30 & 124 & & 23 & 43 & 9 & 138 & 49 & 50 & 44 \\
\hline & & UNIF \% & 8 & 30 & 75 & 71 & -2 & 44 & 63 & & 61 & 52 & 18 & -39 & 29 & ות & 22 \\
\hline & CR & MÉDIA & 7 & 213 & 296 & 491 & 4.6 & 11 & 6 & 64 & 124 & 198 & 53 & 22 & & & \\
\hline & & CV\% & 7 & 54 & 31 & 38 & 12 & 40 & 158 & 5 & 32 & 34 & 42 & 109 & 53 & 10 & 46 \\
\hline & & UNIF \% & 7 & -36 & 48 & -3 & 10 & & 31 & & 18 & 45 & 21 & -28 & 16 & 16 & 0 \\
\hline RLe3 & $\mathrm{AC}$ & 50 & 1 & 480 & 230 & 290 & 5.3 & 1 & 6 & & 105 & 227 & & 0 & & & \\
\hline \multirow[t]{6}{*}{ RLe4 } & A & MĖDIA & 17 & 302 & 325 & 373 & 4.9 & 20 & 27 & 79 & 120 & 175 & 65 & 4 & & & \\
\hline & & $\mathrm{CV} \%$ & 17 & 33 & 19 & 20 & 11 & 4 & 98 & 4. & 26 & 65 & 24 & 128 & 50 & & \\
\hline & & UNIF \% & 17 & 15 & 70 & 70 & 12 & 10 & 71 & 5 & 57 & 27 & 8 & -29 & 28 & 31 & 2 \\
\hline & CR & MÉDIA & 14 & 289 & 306 & 406 & 4.8 & & 18 & & 132 & 232 & 1 & 15 & & & \\
\hline & & $\mathrm{CV} \%$ & 14 & 55 & 22 & 32 & 12 & & 183 & & 45 & 58 & & 158 & 68 & 74 & 5 \\
\hline & & UNIF \% & 14 & -39 & 64 & 14 & 5 & 1 & 20 & & -16 & 7 & 9 & -86 & -3 & -7 & -1 \\
\hline \multirow[t]{2}{*}{ RLe5 } & A & MÉDIA & 2 & 165 & 355 & 480 & 4.6 & 15 & 31 & 11 & 181 & 266 & & & & & \\
\hline & C & MÉDIA & 2 & 24 & 340 & 415 & 4.5 & 17 & 20 & 10 & 179 & 35 & & 6 & & & \\
\hline \multirow[t]{2}{*}{ RLe6 } & A & 53 & 1 & 41 & 220 & 37 & 5. & 3 & 58 & 12 & 187 & 28 & & & & & \\
\hline & CR & 53 & 1 & 190 & 120 & 690 & 5.8 & 11 & 5 & 102 & 136 & 155 & 15 & 0 & & & \\
\hline \multirow[t]{3}{*}{ RUbe } & A & MÉDIA & 4 & 378 & 343 & 280 & 4.5 & 22 & 8 & 31 & 66 & 41 & 49 & 17 & & & \\
\hline & & $\mathrm{CV} \%$ & 4 & 20 & 12 & 27 & 8.8 & 34 & 60 & 42 & 25 & 74 & 38 & 129 & 45 & 43 & \\
\hline & & UNIF \% & 4 & 47 & 80 & 59 & 29 & 3 & 82 & 57 & 58 & 16 & 19 & -29 & 43 & 43 & \\
\hline \multirow[t]{3}{*}{ RUbe } & C & MEDDIA & 4 & 295 & 323 & 383 & 4.6 & 10 & 3 & 42 & 78 & 128 & 61 & 22 & & & \\
\hline & & $\mathrm{CV} \%$ & 4 & 392 & 295 & 198 & 14 & 32 & 53 & 54 & 40 & 35 & 52 & 182 & 198 & 120 & \\
\hline & & UNIF \% & 4 & -888 & -383 & -430 & -8 & 49 & 77 & 27 & -4 & 44 & & -114 & -155 & -126 & \\
\hline
\end{tabular}

Obs.- Número de perfis amostrados; Arg.- Argila; MO- Matéria orgânica; P- Fósforo; S- Soma de bases; TargAtividade da argila; V- Saturação por bases; m- Saturação por aluminio; e IM- Índice Médio. 
logaritmo na base 10 da atividade do hidrogênio; se fossem medidos os CV\% da atividade do hidrogênio, os valores seriam bem mais altos.

Observa-se, também, que quanto maior o número de pontos observados, menor é o coeficiente de variação e o limite de confiança das unidades de mapeamento, aumentando a confiabilidade das informações.

Os solos com horizonte B textural (ALISSOLOS CRÔMICOS, ARGISSOLOS VERMELHO-AMARELOS, ARGISSOLOS VERMELHOS e LUVISSOLOS CRÔMICOS - Podzólicos) apresentam uma variabilidade baixa (CV em média menor que $30 \%$ ) para teores de areia total e argila. Quando comparado entre os horizontes A e $\mathrm{B}$, observa-se nestes solos, normalmente, uma menor variabilidade no horizonte B. Esta menor variabilidade também ocorre nos NITOSSOLOS VERMELHOS (Terra Roxa Estruturada) e CAMBISSOLOS HÁPLICOS (Cambissolos), e nas camadas subsuperficiais dos GLEISSOLOS HÁPLICOS (Gleis) e dos NEOSSOLOS LITÓLICOS (Solos Litólicos).

Vieira (1997), também, observou em Latossolo Roxo da Região de Campinas $\mathrm{SP}, \mathrm{CV} \%$ maiores no horizonte A do que no horizonte B para atributos de solos, argila, silte e atributos químicos.

A saturação por alumínio apresenta, com poucas exceções, índices altos de coeficiente de variação, demonstrando a alta variabilidade deste atributo nos solos estudados. Nota-se também, que a variabilidade da saturação por alumínio é maior nas unidades de mapeamento que são eutróficas ou distróficas, reduzindo nas unidades de mapeamento classificadas como ALISSOLOS CRÔMICOS ou Alumínicos, apesar de ainda permanecerem altas. Observa-se que na maioria das unidades de mapeamento, assim como na média das unidades de mapeamento, o CV\% para teor de alumínio ( $\mathrm{Al}$ ) ou saturação por alumínio $(\mathrm{m})$ é maior que na área total.

Nos NEOSSOLOS LITÓLICOS (RL), diferentemente do que acontece nos solos com horizonte B textural e NITOSSOLOS, a variabilidade nos horizontes subsuperficiais é maior que no horizonte $\mathrm{A}$, isto é devido a fatores tais como: a variação 
de horizontes nos NEOSSOLOS LITÓLICOS, ocorrendo horizontes C, CR, C/R ou R em subsuperficie; material de origem variável (sedimentos), como observado por alguns autores (Coelho et al., 1994; Demattê et al., 1977; Demattê et al., 1992 e Scatolini \& Moniz, 1992); e a variabilidade da textura nos NEOSSOLOS LITÓLICOS é maior que nos solos com horizonte B textural.

Comparando-se as unidades de mapeamento, através do CV\% na Tabela 7, observa-se que para o horizonte A a unidade de mapeamento NVe apresenta a maior quantidade de atributos que apresentam CV\% com os menores valores, além de possuir os menores valores de $\mathrm{CV} \%$ dos índices IM2 (índice geral reduzido dos CV\%) e IM3 (índice médio dos CV\% dos atributos de solos mais importantes para a classificação do solo - areia total, argila, atividade da argila, saturação por bases e saturação por alumínio); a unidade que apresenta o menor IM1 (índice geral dos CV\% - todos os atributos de solos) é PVAel2. Ao observar os valores dos índices médios para o horizonte $\mathrm{B}$, constata-se que os menores índices são: IM1 - PVAel2; IM2 - PVe; e IM3 - ACt1, sendo que no conjunto dos três índices as unidades PVAel2, PVe e NVe apresentam os menores valores.

Ressalta-se que a unidade RUbe (NEOSSOLOS FLÚVICOS) apresenta os maiores valores para $\mathrm{CV} \%$ em vários atributos de solos no horizonte subsuperficial, principalmente os relacionados à textura (conteúdo de areia total e suas frações, silte e argila) e saturação por alumínio; além dos três índices médios, que são expressivamente mais altos. Esta elevada variabilidade da unidade RUbe pode ser explicada pelo tipo de material de origem da classe principal - sedimentos aluviais heterogêneos- e também por ser esta unidade composta de uma associação complexa de classes de solos.

Beckett e Webster (1971) em revisão sobre variabilidade das propriedades de solos enfatizaram que alguns processos geomórficos, por exemplo, depósitos aluviais na planície de um rio, dão origem a padrões recorrentes de material de solo. Regularmente sedimentos de rios dão origem a padrões regulares de diferenças de solo. Até mesmo dentro de afloramentos de rochas sedimentares, aparentemente uniformes, pode haver diferenças de solos regionais, como resultado de gradientes geoquímicos na hora da 
deposição. Perdas de solos episódicas por escorrimento superficial, rastejo, erosão por voçorocamento, ou erosão através do vento, e a correspondente deposição, novamente produz pequenas alternações de materiais do solo. O padrão destes ainda será mais complicado se eles forem associados com a perda, retenção ou recobrimento de superficies de solo em graus variados de desenvolvimento.

Saldaña et al. (1998), estudando a variabilidade espacial de propriedades de solos em três terraços do Rio Henares (Espanha), observaram redução da variabilidade dos depósitos mais novos para os mais velhos, mostrando incremento da homogeneidade do solo com o tempo. Isto indica que solos mais jovens, como os NEOSSOLOS FLÚVICOS, apresentam maior variabilidade que solos mais maduros, como os solos com horizonte B textural, de acordo com os resultados apresentados neste trabalho. Além disso o material de origem dos NEOSSOLOS FLÚVICOS é diferente.

Considerando o CV\% médio ponderado do mapa detalhado de solos-2000, apresentado na Tabela 8, observa-se que fazem parte do grupo I com $\mathrm{CV}$ menor que $40 \%$ - menor variabilidade - os atributos areia total, silte, argila, pHs, CTC do solo e V\% para o horizonte A. No horizonte B areia total não faz parte deste grupo. O grupo III, que apresenta CV maior que $70 \%$ - maior variabilidade - encontram-se no horizonte A, areia muito grossa, areia grossa, Fósforo, Alumínio, $\mathrm{T}$ da argila e saturação por alumínio. No horizonte $B$, entra potássio e sai $T$ argila no grupo de maior variabilidade.

Areia total e silte são os atributos de menor variabilidade no horizonte A, enquanto que Fósforo, Alumínio e saturação por alumínio são os que apresentam maior variabilidade tanto no horizonte $\mathrm{A}$ como no $\mathrm{B}$. Teor de argila apresenta o menor valor de CV\%. Esses resultados mostram que a variabilidade é menor nos atributos físicos que nos químicos. A maior variabilidade dos atributos químicos é devido, principalmente, ao material de origem. 


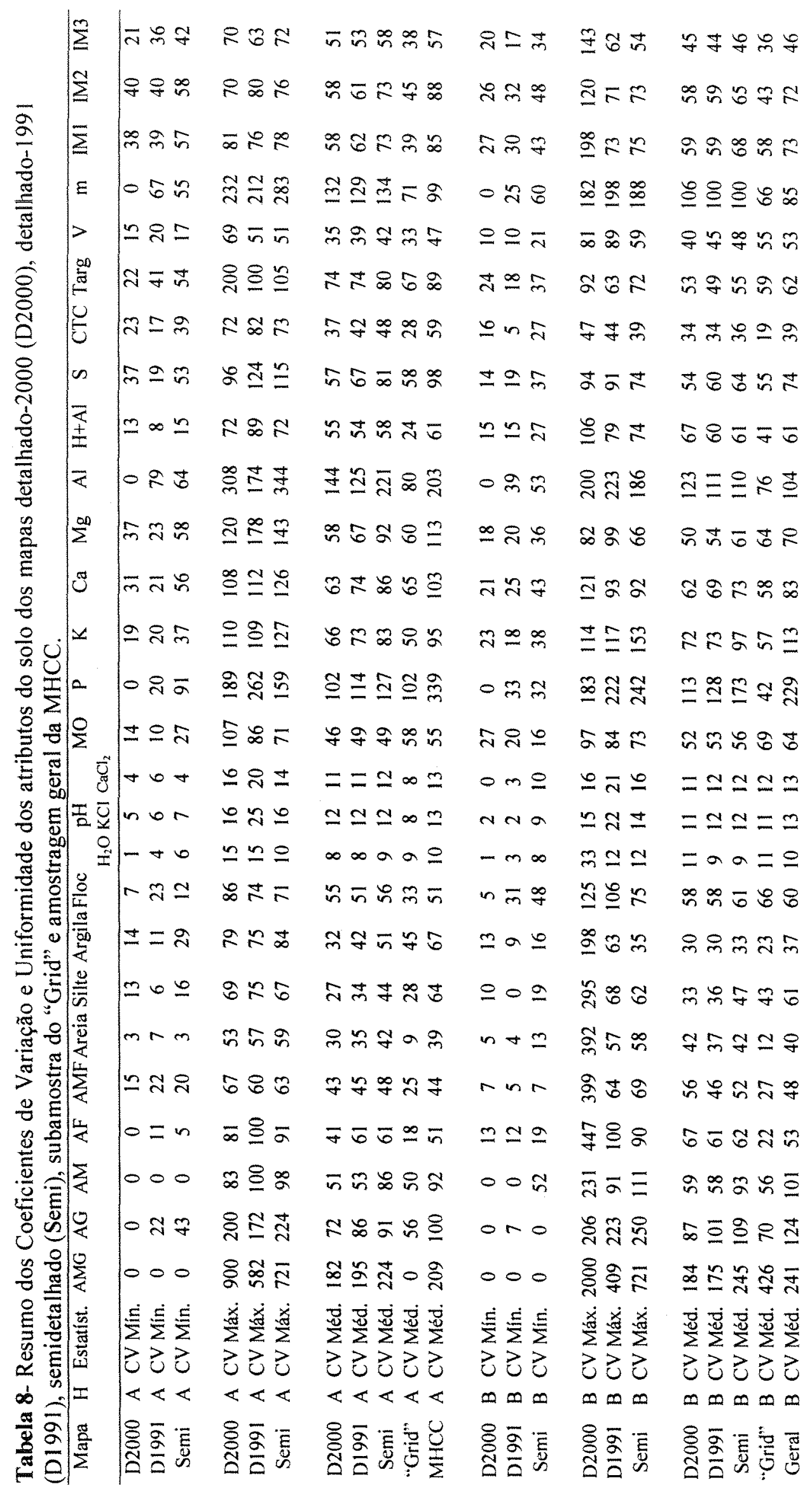




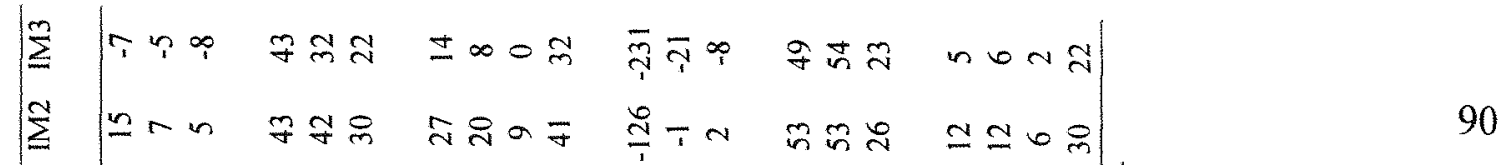

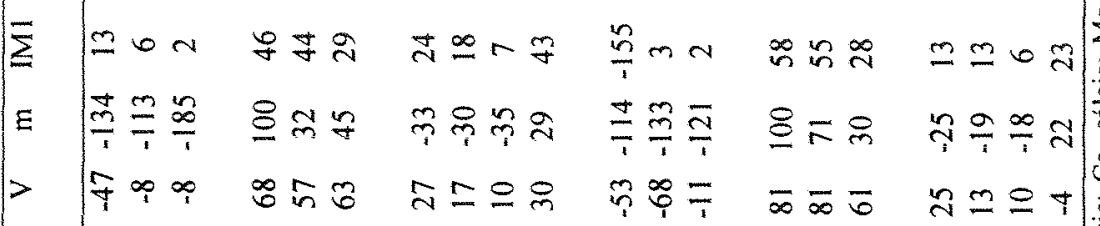

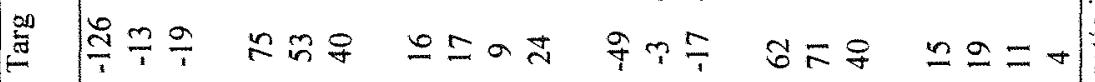

U तิฬ

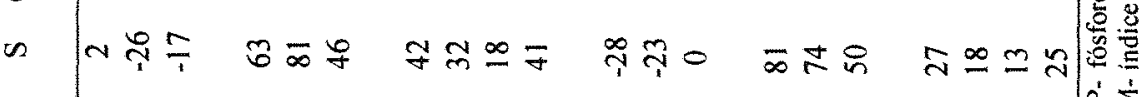

䍃

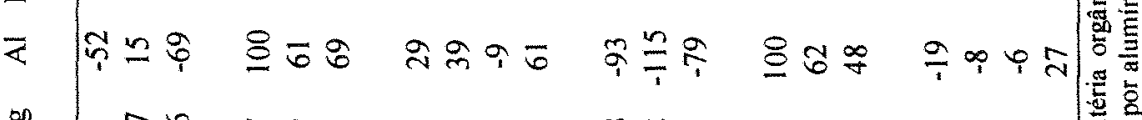

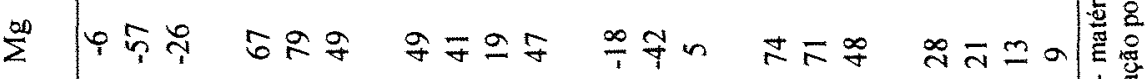

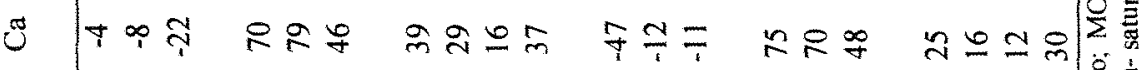

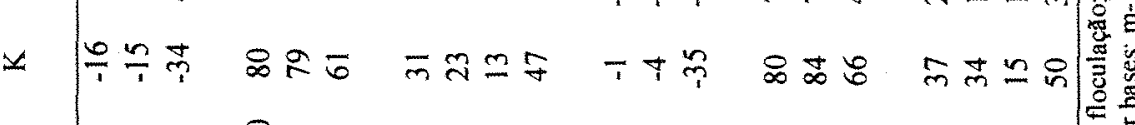

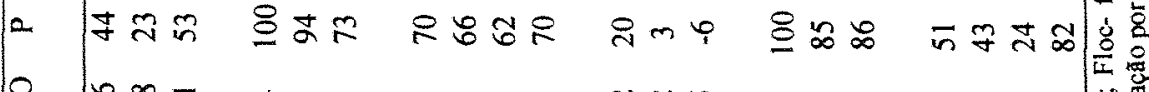

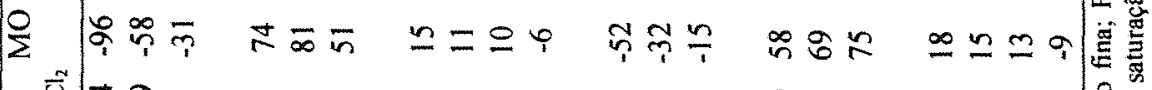

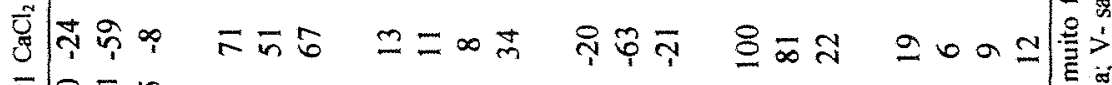

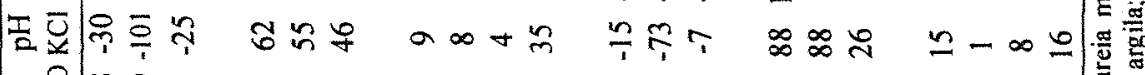

胥守

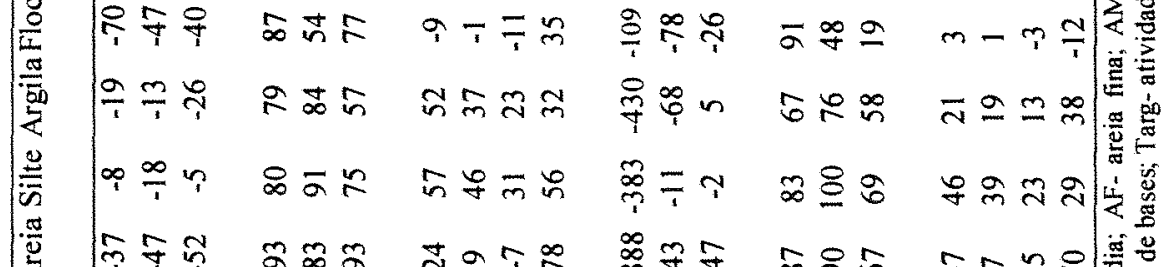

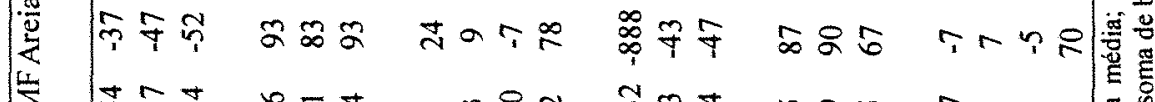

传尔

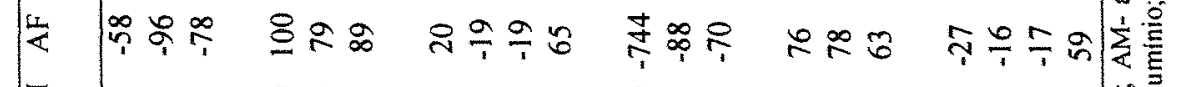

$\sum \mid$\begin{tabular}{llll}
\hline & 0
\end{tabular}

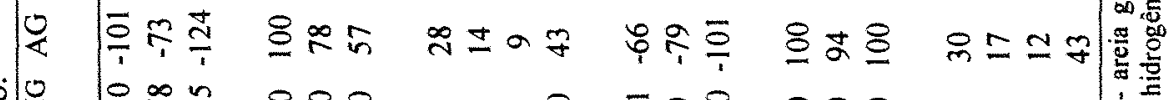

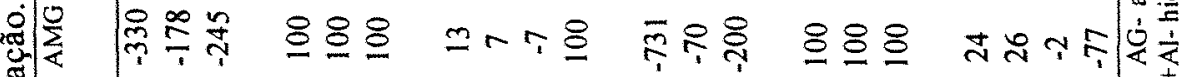

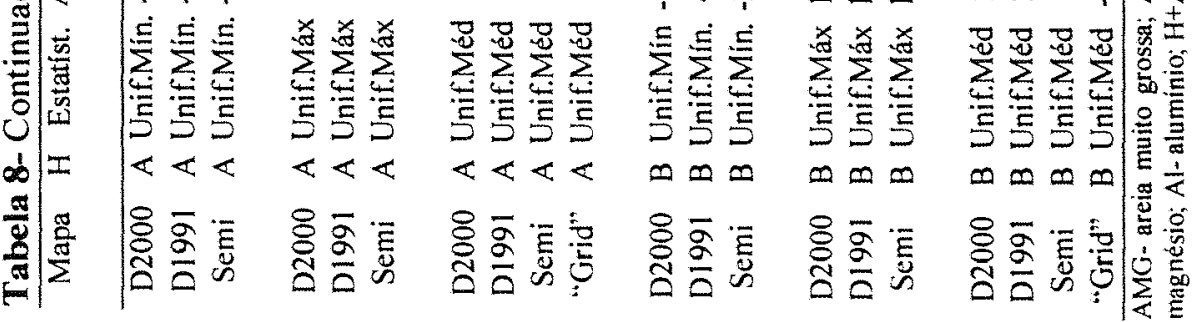


Beckett e Webster (1971) concluíram que ao nível de série, CVs dentro de unidades de mapeamento são ligeiramente mais altos que CVs dentro de unidades taxonômicas. Os nossos resultados também mostram que $\mathrm{CVs}$ de unidades de mapeamento composta por apenas uma unidade taxonômica, normalmente apresentam menores valores que os CVs de unidades de mapeamento composta por mais de uma unidade taxonômica.

Trabalhando com solos arenosos, Marsman \& Gruijter (1986), também, calcularam o coeficiente de variação e encontraram que metade das propriedades de solo parece ter CVs de aproximadamente 20\% (grupo I). As outras propriedades de solo alcançam CVs de $30 \%$ a $40 \%$ (grupo II). Somente conteúdo de matéria orgânica a $50 \mathrm{~cm}$ de profundidade alcança CVs alto, com valores médios de $70 \%$ e $94 \%$ para os dois grupos de mapas de solo estudados.

Quando utiliza-se o Índice de Uniformidade dos Atributos do Solo (1 - CV\% da unidade de mapeamento/CV\% da área total) para comparação (Tabela 7 e 8 ), nota-se que no grupo I (uniformidade maior ou igual a 40\%), além do conteúdo de silte e argila, que apresentava menores $\mathrm{CV} \%$ no horizonte $\mathrm{A}$, aparece também areia média, $\mathrm{P}, \mathrm{Mg}$ e Soma de bases, que mostram as maiores reduções do coeficiente de variação médio do mapa detalhado-2000 em relação à área total. No horizonte $B$ as maiores reduções do CV\% médio do mapa - grupo I do índice de uniformidade - são para os atributos areia média, silte e Fósforo. O fósforo, apesar de apresentar alto CV\% nas unidades de mapeamento, apresenta uma uniformidade elevada, com grande redução do CV\% médio das unidades em relação à área total da microbacia, isto é devido ao elevado valor de $\mathrm{CV} \%$ para fósforo na microbacia.

Os menores valores de uniformidade, menor redução da variabilidade (CV\%) da média das unidades de mapeamento em relação a área total, - grupo III, com uniformidade menor que $10 \%$ - para os atributos de solos no horizonte A, foram: conteúdo de areia muito fina, \% floculação de argila, $\mathrm{pH}$ em $\mathrm{KCl}$ e saturação por alumínio. Já no horizonte $\mathrm{B}$ os atributos que apresentaram menores valores de 
uniformidade - grupo III - foram conteúdo de areia fina, areia muito fina e areia total; \% de floculação de argila; $\mathrm{pH}$ em $\mathrm{H}_{2} \mathrm{O} ; \mathrm{Al} ; \mathrm{H}+\mathrm{Al}$; e m (saturação por alumínio).

Beckett \& Burrough (1971) investigaram a variabilidade de solo em Berkshire, Inglaterra. Eles usaram a variância relativa (1-RV) como um parâmetro para medir até que ponto a variabilidade das propriedades de solo dentro das unidades de mapeamento é menor que a sua variabilidade na área total mapeada.

(RV = variância agrupada dentro de unidades de mapeamento/variância total).

Eles calcularam variâncias relativas para várias propriedades de solo: conteúdo de argila, conteúdo de areia, conteúdo de matéria orgânica, profundidade do carbonato, profundidade do cascalho, profundidade do mosqueado e profundidade da rocha. Os resultados mostraram valores variando de $70 \%$ a $100 \%$, com a maioria das propriedades alcançando valores de $90 \%$ ou mais. As variâncias relativas dentro de unidades de classificação foram iguais ou só ligeiramente menores que aquelas das unidades de mapeamento correspondentes. Marsman \& Gruijter (1986), calcularam em seus estudos variâncias relativas de propriedades de solo para mapas de solo e encontraram valores que variam entre $55 \%$ e $80 \%$.

Neste trabalho (Tabelas 7 e 8 e Anexo A) os valores de uniformidade, que podem ser comparados aos resultados de variância relativa (1-RV) encontrados em Beckett \& Burrough (1971) e Marsman \& Gruijter (1986), foram mais baixos com valores médios do mapa detalhado-2000, no horizonte $\mathrm{A}$, menores que $50 \%$ para a maioria dos atributos de solos, com resultados maiores que $50 \%$ para conteúdo de silte e argila e de $70 \%$ para fósforo assimilável. O índice médio geral (IM1) é de $24 \%$ e o indice médio para classificação (IM3) é de 14,2\%. Valores negativos, isto é, variabilidade maior das unidades de mapeamento que da área como um todo, foram encontrados para \% de floculação da argila e saturação por alumínio. Para o horizonte B (horizonte subsuperficial) os resultados de uniformidade são mais baixos, com valores quase sempre menores que $30 \%$; conteúdo de silte (46\%) e fósforo (51\%) são os maiores. Os índices médios, também, são menores: $12,8 \%$ para IM1 e 4,9\% para IM3. Vários atributos apresentam variabilidade maior na média das unidades de mapeamento que na 
área total (valores negativos de uniformidade): conteúdo de areia fina, areia muito fina e areia total; $\mathrm{pH}$ em $\mathrm{H}_{2} \mathrm{O}$; $\mathrm{Al}$ trocável e $\mathrm{H}+\mathrm{Al}$; e saturação por alumínio (m).

Comparando-se a variabilidade entre os horizontes A e B, observa-se que o horizonte $\mathrm{A}$ apresenta menor variabilidade que o horizonte $\mathrm{B}$ em mais da metade dos atributos, entre os quais: areia total, matéria orgânica, fósforo e saturação por bases,

enquanto no horizonte B a variabilidade é menor no conteúdo de argila, CTC do solo, T da argila e saturação por alumínio, atributos utilizados como diferenciadores no nosso sistema de classificação de solos. Dentre as classes de solos, observa-se que os NEOSSOLOS FLÚVICOS são os que apresentam maior variabilidade no horizonte B.

\subsubsection{Mapa detalhado de solos-1991}

A análise da precisão dos atributos de solos do mapa detalhado de solos-1991 foi baseada nas informações da Tabela 9 e Anexo B.

Observando-se os dados para o mapa detalhado de solos-1991 constata-se, também, uma grande variabilidade interna (indicada pelos altos valores de CV\% normalmente acima de 50\%) nas unidades de mapeamento de solos, dos atributos: conteúdo de MO e P; soma de bases; atividade da argila, saturação por bases e saturação por alumínio. Esta alta variabilidade ocorre tanto no horizonte A como no horizonte B. Os menores valores do coeficiente de variação ocorrem para: $\mathrm{pH}$; conteúdo de areia, silte e argila; e CTC do solo. Estes valores mais baixos do coeficiente de variação para os atributos areia total, silte e argila, indicam a maior eficiência em mapear os solos, observada pela redução do CV\%, na $\mathrm{MHCC}$, em relação à textura do que em relação aos atributos químicos dos solos. O mesmo resultado foi obtido no mapa detalhado-2000. Este fato dificulta o enquadramento dos solos no Sistema de Classificação, devido a alta variabilidade de alguns atributos químicos, como já observado anteriormente.

Comparando-se as unidades de mapeamento, através do CV\% no Anexo B e utilizando os índices médios como indicadores, observa-se para o horizonte $\mathrm{A}$ que a unidade de mapeamento $P V 7$ apresenta os menores valores de CV\% para IM1 (índice geral dos CV\% para todos atributos de solos) e IM2 (índice geral reduzido dos CV\%), 
Tabela 9- Resumo dos atributos do solo das unidades de mapeamento do mapa detalhado$1991^{*}$

\begin{tabular}{|c|c|c|c|c|c|c|c|c|c|c|c|c|c|c|c|c|c|}
\hline Mapa & Hor & Estat. & Obs. A & Areia & Silte & Arg. & $\mathrm{pH}$ & MO & $\mathrm{P}$ & S & CTC & Targ & $\mathrm{V}$ & $\mathrm{m}$ & IM1 & IM2 & IM3 \\
\hline & & & & & & & $\mathrm{CaCl}_{2}$ & $\mathrm{gkg}^{-1}$ & $\mathrm{mgkg}^{-1}$ & $---m$ & molc.k & $\mathrm{rg}^{-1}-$ & & $10-\cdots$ & & & \\
\hline \multirow[t]{6}{*}{ PV1 } & A & MÉDIA & 11 & 737 & 132 & 131 & 4.8 & 15 & 87 & 52 & 76 & 252 & 53 & 20 & & & \\
\hline & & $\mathrm{CV} \%$ & 11 & 10 & 42 & 34 & 18 & 51 & 262 & 124 & 82 & 96 & 50 & 121 & 73 & 80 & 52 \\
\hline & & UNIF \% & 11 & 73 & 34 & 48 & -43 & 6 & 23 & -26 & -38 & -9 & -7 & -22 & & 7 & 14 \\
\hline & B & MÉDIA & 11 & 575 & 115 & 309 & 4.5 & 11 & & 39 & 78 & 160 & 49 & 27 & & & \\
\hline & & $\mathrm{CV} \%$ & 11 & 18 & 49 & 28 & 15 & 71 & 205 & 63 & 37 & 53 & 42 & & 63 & 71 & 40 \\
\hline & & UNIF \% & 11 & 54 & 19 & 24 & -11 & -12 & 10 & 1 & & 14 & 21 & -16 & & 6 & 16 \\
\hline \multirow[t]{6}{*}{ PV2 } & A & MÉDIA & 96 & 778 & 103 & 119 & 4.2 & 14 & & 18 & 53 & 197 & 33 & 31 & & & \\
\hline & & $\mathrm{CV} \%$ & 96 & 12 & 42 & 54 & 8.3 & 63 & 89 & 85 & 39 & 87 & 45 & & 72 & 54 & 44 \\
\hline & & UNIF \% & 96 & 69 & 35 & 18 & 34 & -16 & 74 & 1. & 34 & 2 & 5 & & & 27 & 21 \\
\hline & B & MÉDIA & 95 & 589 & 119 & 292 & 4.3 & 11 & & & 88 & 214 & 38 & 5 & & & \\
\hline & & $\mathrm{CV} \%$ & 95 & 18 & 55 & 28 & 11 & 76 & 75 & & 28 & 62 & 57 & & 64 & 53 & 39 \\
\hline & & UNIF \% & 95 & 55 & 9 & 26 & 13 & -19 & 67 & & 28 & 0 & & & 15 & 19 & 16 \\
\hline \multirow[t]{6}{*}{ PV3 } & A & MÉDIA & 31 & 793 & 104 & 104 & 4.5 & 12 & 23 & & 54 & 288 & 42 & 2. & & & \\
\hline & & $\mathrm{CV} \%$ & 31 & 18 & 75 & 75 & 13 & 80 & 158 & & 48 & 100 & 50 & & 76 & 68 & 55 \\
\hline & & UNIF \% & 31 & 53 & -18 & -13 & -8 & -47 & 54 & & 19 & -13 & -6 & & & 11 & \\
\hline & B & MÉDIA & 31 & 640 & 102 & 259 & 4.2 & 12 & 4 & & 90 & 241 & 39 & & & & \\
\hline & & $\mathrm{CV} \%$ & 31 & 20 & 68 & 28 & 11 & 84 & 222 & & 31 & 63 & 59 & & 73 & 63 & 41 \\
\hline & & UNIF \% & 31 & 51 & -11 & 26 & 14 & -31 & 3 & & 20 & -3 & -12 & & & 12 & 13 \\
\hline \multirow[t]{6}{*}{ PV4 } & A & MĖDIA & 3 & 780 & 107 & 113 & 4.4 & 10 & 4 & & 77 & 484 & 35 & & & & \\
\hline & & $\mathrm{CV} \%$ & 3 & 7 & 11 & 37 & 10 & 52 & 25 & & 40 & 41 & 51 & & 3 & 42 & 36 \\
\hline & & UNIF \% & 3 & 82 & 83 & 45 & 1 & 4 & 93 & & 33 & 53 & -1 & & 39 & 39 & 32 \\
\hline & B & MÉDIA & 3 & 623 & 100 & 277 & 3.9 & 5 & 3 & & 111 & 351 & 26 & & & & \\
\hline & & CV\% & 3 & 4 & 0 & 9 & 2.6 & 47 & 33 & & 22 & 30 & 35 & & 30 & 32 & 17 \\
\hline & & UNIF \% & 3 & 90 & 100 & 76 & & 26 & 85 & & 4 & 52 & & & 55 & 53 & 54 \\
\hline \multirow[t]{2}{*}{ PV4pp } & A & Amostra & 1 & 760 & 120 & 120 & 3.9 & 13 & 6 & & 48 & 117 & 38 & 33 & & & \\
\hline & B & Amostra & 1 & 550 & 120 & 330 & 3.7 & & 2 & & 80 & 204 & 40 & 47 & & & \\
\hline \multirow[t]{6}{*}{ PV5 } & A & MÉDIA & 5 & 464 & 238 & 298 & 5.0 & 13 & 14 & & 75 & 159 & 56 & & & & \\
\hline & & $\mathrm{CV} \%$ & 5 & 39 & 25 & 65 & 11 & 60 & 78 & & 3 & 78 & & 96 & 56 & 56 & 52 \\
\hline & & UNIF \% & 5 & 0 & 60 & 2 & 15 & -9 & 77 & & 3 & 12 & & & 19 & 23 & \\
\hline & B & MÉDIA & 5 & 352 & 168 & 480 & 5.0 & 11 & 6 & & 96 & 149 & 56 & 7 & & & \\
\hline & & $\mathrm{CV} \%$ & 5 & 37 & 41 & 17 & 13 & 49 & 115 & 1 & 5 & 37 & 16 & 115 & 48 & 47 & 37 \\
\hline & & UNIF \% & 5 & 8 & 33 & 56 & 3 & 23 & 49 & 7 & 86 & 40 & & -36 & 30 & 33 & 23 \\
\hline \multirow[t]{6}{*}{ PV5pp } & A & MEDDIA & 6 & 435 & 258 & 307 & 5.1 & 17 & 11 & & 115 & 251 & 59 & & & & \\
\hline & & CV\% & 6 & 32 & 29 & 34 & 12 & 5 & 6 & & 43 & 73 & & & 54 & 60 & 63 \\
\hline & & UNIF \% & 6 & 18 & 55 & 49 & 7 & 0 & 8 & & 27 & 18 & 44 & -113 & 26 & 22 & 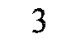 \\
\hline & B & MÉDIA & 6 & 417 & 218 & 365 & 4.9 & 7 & 3 & 6 & 111 & 295 & 60 & 14 & & & \\
\hline & & $\mathrm{CV} \%$ & 6 & 49 & 12 & 52 & 12 & 31 & 45 & & 36 & 43 & 32 & 198 & 65 & 66 & 62 \\
\hline & & UNIF \% & 6 & -23 & 80 & -39 & 10 & 5 & 8 & & $\delta$ & 31 & 40 & -133 & 3 & -1 & -21 \\
\hline \multirow[t]{6}{*}{ PV6 } & A & MĖDIA & 3 & 350 & 310 & 340 & 4.8 & 1 & 27 & & 101 & 155 & 6 & 11 & & & \\
\hline & & $\mathrm{CV} \%$ & 3 & 32 & 6 & 28 & 20 & 10 & 84 & 83 & 40 & 45 & 43 & 96 & 46 & 44 & 41 \\
\hline & & UNIF \% & 3 & 16 & 91 & 57 & -59 & 81 & 75 & 1 & 32 & 49 & 9 & 4 & 27 & 38 & 23 \\
\hline & B & MÉDIA & 3 & 193 & 243 & 563 & 4.5 & 13 & 11 & 64 & 135 & 191 & 46 & 39 & & & \\
\hline & & $\mathrm{CV} \%$ & 3 & 53 & 17 & 25 & 21 & 3 & 127 & 91 & 13 & 31 & 89 & 102 & 60 & 58 & \\
\hline & & UNIF \% & 3 & -34 & 72 & 33 & -63 & 44 & 44 & -23 & 66 & 50 & -68 & -20 & 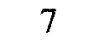 & 16 & \\
\hline
\end{tabular}


Tabela 9- Continuação.

\begin{tabular}{|c|c|c|c|c|c|c|c|c|c|c|c|c|c|c|c|c|c|}
\hline UnMapa & Hor & Estat. & Obs. & Areia & Silte & Arg. & $\mathrm{pH}$ & $\mathrm{MO}$ & $\mathrm{P}$ & $\mathrm{S}$ & CTC & Targ & V & $\mathrm{m}$ & IM1 & IM2 & IM3 \\
\hline & & & & & $-\mathrm{g} \mathrm{kg}^{-}$ & $\ldots$ & $\mathrm{CaCl}_{2}$ & $\mathrm{~kg}^{-1}$ & $\mathrm{mghg}^{-1}$ & $\cdots-m$ & molc.k & & $-\cdots$ & \%on-me & - & $-\%$ & \\
\hline \multirow[t]{2}{*}{ PV6pp } & A & Amostra & 1 & 410 & 310 & 280 & 4.4 & 23 & 26 & 36 & 66 & 20 & 54 & 12 & & & \\
\hline & B & Amostra & 1 & 410 & 300 & 290 & 4.4 & 13 & 6 & 34 & 70 & 125 & 49 & 13 & & & \\
\hline \multirow[t]{6}{*}{ PV7 } & A & MÉDIA & 3 & 577 & 243 & 180 & 4.4 & 18 & 5 & 25 & 50 & 23 & 51 & 19 & & & \\
\hline & & CV \% & 3 & 23 & 32 & 29 & 6.5 & 23 & 20 & 30 & 19 & 63 & 39 & 102 & 39 & 40 & 43 \\
\hline & & UNIF \% & 3 & 42 & 50 & 56 & 48 & 58 & 94 & 70 & 69 & 29 & 18 & -3 & 44 & 42 & 24 \\
\hline & B & MÉDIA & 3 & 457 & 240 & 303 & 4.7 & 13 & 3 & 53 & 71 & 124 & 74 & 9 & & & \\
\hline & & CV \% & 3 & 42 & 52 & 63 & 7.5 & 20 & 78 & 37 & 35 & 24 & 10 & 130 & 47 & 51 & 45 \\
\hline & & UNIF \% & 3 & -7 & 15 & -68 & 43 & 69 & 66 & 49 & 12 & 62 & 81 & -53 & 29 & 20 & 3 \\
\hline \multirow[t]{6}{*}{ PV7pp } & A & MÉDIA & 6 & 475 & 217 & 308 & 4.6 & 21 & 10 & 47 & 96 & 127 & 51 & 9 & & & \\
\hline & & $\mathrm{CV} \%$ & 6 & 8 & 38 & 24 & 6.3 & 55 & 120 & 19 & 17 & 77 & 25 & 124 & 53 & 48 & 43 \\
\hline & & UNIF \% & 6 & 80 & 40 & 64 & 49 & 0 & 65 & 81 & 72 & 13 & 46 & -25 & 39 & 42 & 30 \\
\hline & $B$ & MÉDIA & 6 & 300 & 200 & 500 & 4.6 & 14 & 4 & 59 & 111 & 147 & 55 & 20 & & & \\
\hline & & $\mathrm{CV} \%$ & 6 & 57 & 21 & 40 & 12 & 27 & 87 & 40 & 26 & 18 & 36 & 132 & 58 & 54 & 47 \\
\hline & & UNIF \% & 6 & -43 & 65 & -8 & 10 & 58 & 62 & 45 & 34 & 71 & 32 & -56 & 19 & 20 & -1 \\
\hline \multirow[t]{4}{*}{ PE } & A & MÉDIA & 3 & 537 & 217 & 247 & 5.0 & 18 & 6 & 51 & 85 & 141 & 58 & 2 & & & \\
\hline & & CV \% & 3 & 32 & 37 & 38 & 6 & 14 & 55 & 46 & 30 & 57 & 20 & 173 & 45 & 48 & 53 \\
\hline & & UNIF \% & 3 & 17 & 41 & 43 & 51 & 74 & 84 & 54 & 50 & 35 & 57 & -74 & 40 & 40 & 13 \\
\hline & B & MÉDIA & 2 & 320 & 135 & 545 & 5.5 & 17 & 4 & 62 & 78 & 66 & 78 & 0 & & & \\
\hline \multirow[t]{2}{*}{$\mathrm{TE}$} & A & MÉDIA & 2 & 580 & 200 & 220 & 4.8 & 15 & 6 & 33 & 68 & 130 & 48 & 7 & & & \\
\hline & B & Amostra & 1 & 360 & 150 & 490 & 5.2 & 15 & 5 & 40 & 58 & 39 & 69 & 0 & & & \\
\hline \multirow[t]{2}{*}{ TEP } & A & MÉDIA & 2 & 370 & 225 & 405 & 5.2 & 27 & 64 & 81 & 120 & 116 & 64 & 0 & & & \\
\hline & B & MÉDIA & 2 & 220 & 135 & 645 & 5.7 & 17 & 9 & 75 & 90 & 70 & 81 & 0 & & & \\
\hline \multirow[t]{6}{*}{ Lil } & A & MÉDIA & 39 & 343 & 332 & 325 & 4.6 & 19 & 17 & 65 & 108 & 164 & 55 & 13 & & & \\
\hline & & $\mathrm{CV} \%$ & 39 & 57 & 28 & 38 & 11 & 36 & 125 & 70 & 45 & 70 & 38 & 144 & 62 & 67 & 58 \\
\hline & & UNIF \% & 39 & -47 & 56 & 43 & 12 & 33 & 63 & 29 & 24 & 21 & 20 & -45 & 13 & 12 & -1 \\
\hline & $\mathrm{CR}$ & MÉDIA & 35 & 295 & 303 & 401 & 4.5 & 14 & 11 & 64 & 114 & 191 & 54 & 22 & & & \\
\hline & & $\mathrm{CV} \%$ & 35 & 53 & 34 & 35 & 12 & 47 & 152 & 74 & 43 & 55 & 41 & 104 & 62 & 66 & 48 \\
\hline & & UNIF \% & 35 & -33 & 45 & 8 & 10 & 26 & 34 & 0 & -10 & 10 & 23 & -23 & 6 & 2 & -2 \\
\hline \multirow[t]{2}{*}{ Licc } & A & Amostra & 1 & 130 & 330 & 540 & 3.9 & 23 & 5 & 38 & 116 & 103 & 33 & 53 & & & \\
\hline & $\mathrm{C}$ & Amostra & 1 & 130 & 310 & 560 & 3.8 & 18 & 4 & 42 & 122 & 133 & 34 & 53 & & & \\
\hline \multirow[t]{2}{*}{$\mathrm{Li} 2$} & A & MÉDIA & 2 & 295 & 390 & 315 & 4.8 & 24 & 9 & 52 & 93 & 83 & 54 & 3 & & & \\
\hline & $\mathrm{C} / \mathrm{R}$ & MÉDIA & 2 & 270 & 410 & 320 & 4.5 & 10 & 8 & 32 & 70 & 125 & 45 & 9 & & & \\
\hline \multirow[t]{6}{*}{$\mathrm{Li} 3$} & A & MÉDIA & 4 & 323 & 315 & 363 & 4.8 & 16 & 27 & 86 & 136 & 261 & 65 & 6 & & & \\
\hline & & $\mathrm{CV} \%$ & 4 & 21 & 22 & 11 & 14 & 86 & 159 & 34 & 19 & 49 & 37 & 100 & 46 & 51 & 36 \\
\hline & & UNIF \% & 4 & 45 & 65 & 84 & -11 & -58 & 53 & 66 & 68 & 45 & 21 & -1 & 32 & 33 & 32 \\
\hline & CR & MÉDIA & 4 & 283 & 338 & 380 & 4.5 & 13 & 35 & 72 & 177 & 370 & 46 & 35 & & & \\
\hline & & CV \% & 4 & 8 & 16 & 12 & 16 & 75 & 183 & 49 & 32 & 41 & 69 & 104 & 45 & 52 & 39 \\
\hline & & UNIF \% & 4 & 80 & 74 & 67 & -19 & -17 & 20 & 33 & 18 & 33 & -31 & -23 & 27 & 26 & 21 \\
\hline \multirow[t]{6}{*}{$\mathrm{Li} 4$} & A & MÉDIA & 9 & 349 & 319 & 332 & 4.7 & 19 & 20 & 70 & 127 & 209 & 52 & 9 & & & \\
\hline & & CV \% & 9 & 51 & 27 & 35 & 10 & 20 & 85 & 65 & 45 & 63 & 43 & 183 & 56 & 62 & 63 \\
\hline & & UNIF \% & 9 & -32 & 57 & 47 & 23 & 64 & 75 & 34 & 25 & 29 & 9 & -85 & 21 & 17 & -5 \\
\hline & CR & MÉDIA & 9 & 320 & 236 & 444 & 4.3 & 12 & 6 & 59 & 145 & 258 & 42 & 28 & & & \\
\hline & & CV \% & 9 & 45 & 19 & 33 & 9.8 & 21 & 89 & 56 & 44 & 49 & 50 & 70 & 51 & 52 & 41 \\
\hline & & UNIF \% & 9 & -14 & 69 & 12 & 25 & 67 & 61 & 24 & -13 & 21 & 6 & 18 & 21 & 19 & 7 \\
\hline
\end{tabular}


Tabela 9- Continuação.

\begin{tabular}{|c|c|c|c|c|c|c|c|c|c|c|c|c|c|c|c|c|c|}
\hline JnMapa & Hor & Estat. & Obs. & Areia & Silte & Arg. & $\mathrm{pH}$ & $\mathrm{MO}$ & $\mathrm{P}$ & $S$ & CTC & Targ & $\mathrm{V}$ & $\mathrm{m}$ & IM1 & IM2 & $\mathrm{IM} 3$ \\
\hline & & & & & & & $\mathrm{CaCl}_{2}$ & $\mathrm{~g} \mathrm{~kg}^{-1}$ & $\mathrm{mgkg}$ & $---m$ & molc.k & $g^{-1}-$ & $\ldots$ & $6-\cdots$ & 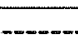 & 0 & \\
\hline \multirow[t]{2}{*}{ Li5 } & A & Amostra & 1 & 620 & 220 & 160 & 3.8 & 23 & 6 & 7 & 55 & 0 & 13 & 75 & & & \\
\hline & B & Amostra & 1 & 380 & 190 & 430 & 3.9 & 23 & 2 & 30 & 106 & 106 & 28 & 56 & & & \\
\hline \multirow[t]{2}{*}{ Li6 } & A & MÉDIA & 2 & 125 & 335 & 540 & 3.9 & 15 & 29 & 78 & 233 & 362 & 32 & 50 & & & \\
\hline & $\mathrm{C}$ & MÉDIA & 2 & 250 & 320 & 430 & 4.9 & 20 & 62 & 137 & 178 & 285 & 78 & 3 & & & \\
\hline \multirow[t]{2}{*}{$\mathrm{Li} 7$} & A & MĖDIA & 2 & 605 & 160 & 235 & 4.8 & 23 & 31 & 72 & 111 & 148 & 58 & 15 & & & \\
\hline & B & MÉDIA & 2 & 410 & 110 & 480 & 4.8 & 12 & 4 & 56 & 103 & 145 & 45 & 42 & & & \\
\hline \multirow[t]{6}{*}{$\mathrm{Cbl}$} & A & MÉDIA & 8 & 499 & 241 & 260 & 5.2 & 18 & 16 & 80 & 124 & 281 & 64 & 7 & & & \\
\hline & & $\mathrm{CV} \%$ & 8 & 27 & 24 & 33 & 16 & 42 & 116 & 69 & 49 & 64 & 31 & 162 & 70 & 68 & 53 \\
\hline & & UNIF \% & 8 & 30 & 63 & 50 & -28 & 22 & 66 & 30 & 18 & 28 & 35 & -64 & 6 & 12 & 13 \\
\hline & $\mathrm{B}$ & MÉDIA & 8 & 308 & 231 & 461 & 4.5 & 14 & 2 & 55 & 130 & 202 & 43 & 35 & & & \\
\hline & & $\mathrm{CV} \%$ & 8 & 44 & 50 & 19 & 18 & 41 & 65 & 51 & 26 & 36 & 48 & 91 & 57 & 56 & 40 \\
\hline & & UNIF \% & 8 & -10 & 18 & 50 & -38 & 36 & 71 & 31 & 33 & 41 & 10 & -8 & 13 & 16 & 14 \\
\hline \multirow[t]{2}{*}{$\mathrm{Cb} 2$} & A & Amostra & 1 & 720 & 160 & 120 & 4.3 & 10 & 3 & 37 & 89 & 522 & 41 & 23 & & & \\
\hline & B & MÉDIA & 2 & 650 & 145 & 205 & 4.0 & 7 & 2 & 26 & 135 & 583 & 19 & 81 & & & \\
\hline \multirow[t]{2}{*}{$\mathrm{Cb} 3$} & A & Amostra & 1 & 470 & 280 & 250 & 4.0 & 10 & 3 & 39 & 133 & 425 & 29 & 66 & & & \\
\hline & B & Amostra & 1 & 430 & 340 & 230 & 3.7 & 10 & 3 & 31 & 149 & 536 & 21 & 78 & & & \\
\hline \multirow[t]{2}{*}{ Hil } & A & MÉDIA & 2 & 325 & 400 & 275 & 4.7 & 19 & 11 & 42 & 114 & 258 & 45 & 15 & & & \\
\hline & B & MÉDIA & 2 & 260 & 310 & 430 & 3.8 & 12 & 3 & 14 & 97 & 159 & 15 & 75 & & & \\
\hline \multirow[t]{2}{*}{$\mathrm{Hi} 2$} & A & Amostra & 1 & 290 & 470 & 240 & 4.0 & 15 & 9 & 27 & 141 & 424 & 19 & 23 & & & \\
\hline & $\mathrm{C}$ & Amostra & 1 & 270 & 300 & 430 & 3.8 & 3 & 3 & 43 & 213 & 477 & 20 & 41 & & & \\
\hline \multirow[t]{2}{*}{ A } & A & MÉDIA & 2 & 400 & 355 & 245 & 4.3 & 28 & 10 & 25 & 72 & 20 & 38 & 29 & & & \\
\hline & $\mathrm{C}$ & MÉDIA & 2 & 325 & 260 & 415 & 4.3 & 9 & 5 & 27 & 79 & 127 & 44 & 40 & & & \\
\hline
\end{tabular}

* Amostragem georeferenciada do levantamento detalhado de solos-2000 sobreposta ao mapa detalhado-1991.

Obs.- Número de perfis amostrados; Arg.- Argila; MO- Matéria orgânica; P. Fósforo; S- Soma de bases; TargAtividade da argila; V-Saturação por bases; m- Saturação por alumínio; e IM- Índice Médio.

enquanto $\mathrm{Li3}$ apresenta o IM3 (índice médio dos CV\% dos atributos mais importantes para a classificação do solo) mais baixo. A unidade $P V 4$ também apresenta índices médios mais baixos que as demais unidades. Enquanto que a unidade de mapeamento PVl apresenta os índices médios mais elevados para o horizonte A. Ao observar os valores dos índices médios para o horizonte $\mathrm{B}$, constata-se que os menores índices são da unidade de mapeamento PV4, ou seja, a unidade de mapeamento PV4 apresenta, no geral, mais alta homogeneidade que as outras unidades.

Considerando o CV\% médio ponderado do mapa detalhado de solos-1991 (Tabela 8), observa-se que fazem parte do grupo de menor variabilidade - grupo I com $\mathrm{CV}$ menor que $40 \%$ - os atributos: conteúdo de areia total e silte; $\mathrm{pH}$ em $\mathrm{H}_{2} \mathrm{O}, \mathrm{KCl}$ e $\mathrm{CaCl}_{2}$; e $\mathrm{V} \%$; para o horizonte $\mathrm{A}$. Enquanto para o horizonte $\mathrm{B}$ os atributos são: conteúdo de areia total, silte e argila; $\mathrm{pH}$ em $\mathrm{H}_{2} \mathrm{O}, \mathrm{KCl}$ e $\mathrm{CaCl}_{2}$; e CTC do solo. Os 
atributos de solos que fazem parte do grupo de maior variabilidade - grupo III com CV maior que $70 \%$ - para o horizonte A, são: conteúdo de areia muito grossa e areia grossa; $\mathrm{P} ; \mathrm{K} ; \mathrm{Ca} ; \mathrm{Al}$; atividade da argila e m (saturação por alumínio); para o horizonte $\mathrm{B}$, são os mesmos do horizonte $\mathrm{A}$, com exceção dos atributos $\mathrm{Ca}$ e atividade da argila.

Em relação à uniformidade observamos que os atributos que apresentam maior uniformidade (grupo I - uniformidade maior que 40\%), são: horizonte A - conteúdo de areia média e silte; fósforo e magnésio; horizonte $\mathrm{B}$ - areia média e fósforo. Os atributos que apresentam menores uniformidades (grupo III - uniformidade menor que 10\%), são: horizonte $\mathrm{A}$ - conteúdo de areia muito grossa, areia fina, areia muito fina, areia total; \% floculação da argila; pH em KCl; saturação por alumínio e IM3; horizonte B - conteúdo de areia fina, areia muito fina, areia total; \% floculação da argila; $\mathrm{pH}$ em $\mathrm{H}_{2} \mathrm{O}, \mathrm{KCl}$ e $\mathrm{CaCl}_{2}$; concentração de alumínio e $\mathrm{H}+\mathrm{Al}$; saturação por alumínio e IM3.

É importante ressaltar que a uniformidade média apresenta valores negativos, isto é, a variância $(\mathrm{CV} \%)$ é maior na média das unidades de mapeamento do que na área como um todo, para alguns atributos de solos: horizonte $\mathrm{A}$ - conteúdo de areia fina $\mathrm{e}$ areia muito fina; \% de floculação; e saturação por alumínio; horizonte B - conteúdo de areia fina; concentração de alumínio e saturação por alumínio. Isto ocorre, como já foi observado anteriormente, principalmente devido à alta variabilidade do material de origem e ao relevo movimentado existente na microbacia.

O mapa detalhado-1991 apresenta uma alta variância nas suas unidades de mapeamento, assim como no mapa detalhado-2000, com valores em média maiores que esse último. Observa-se uma menor variância em relação à textura do que em relação aos atributos químicos dos solos. Constata-se também que a uniformidade é em média menor no horizonte $\mathrm{B}$ que no horizonte $\mathrm{A}$, com os índices médios sendo menores no horizonte $\mathrm{B}$ em relação ao horizonte $\mathrm{A}$. Isto é consequência da variabilidade do material de origem. 


\subsubsection{Mapa semidetalhado de solos}

A Tabela 10 mostra a média, coeficiente de variação e índice de uniformidade de alguns atributos do solo das unidades de mapeamento do mapa semidetalhado. O Anexo C mostra a estatística básica (média, número de pontos, máximo, mínimo, coeficiente de variação, limite de confiança para uma significância de $95 \%$ e uniformidade) deste mapa.

De acordo com esses dados (Tabela 10) identifica-se grande variabilidade interna dos atributos argila, fósforo, matéria orgânica, atividade da argila e saturação por alumínio (indicada pelos altos valores de CV\% - normalmente acima de 50\%). Nota-se também, a baixa variabilidade dos valores de $\mathrm{pH}$ com coeficiente de variação quase sempre inferior a $10 \%$. Porém ao contrário das unidades de mapeamento do mapa detalhado de solos-2000 (Tabela 7), a variabilidade dos atributos das unidades de mapeamento do mapa semidetalhado (Tabela 10), de modo geral, é maior no horizonte B (ou em subsuperficie) do que no horizonte A. A explicação para essa observação está no fato de que, como o horizonte $\mathrm{B}$ é o horizonte diagnóstico dos ARGISSOLOS, ALISSOLOS, LUVISSOLOS, NITOSSOLOS e CAMBISSOLOS (Podzólicos, Terra Roxa e Cambissolos), e a variabilidade seria menor em unidades de mapeamento mais uniformes, quando se considera a uniformidade das características morfogenéticas. Porém, as unidades de mapeamento do mapa semidetalhado de solos são menos uniformes que as do mapa detalhado-2000 (Tabela 7) e mapa detalhado-1991 (Tabela 9), o que por si só, já seria suficiente para esperar um aumento da variabilidade dos atributos.

Verifica-se também na Tabela 10, que nas unidades de mapeamento do mapa semidetalhado a variabilidade para o parâmetro textura, principalmente areia total e argila, é maior que nas unidades de mapeamento do mapa detalhado. Essa maior variabilidade também é esperada no mapa semidetalhado, devido a menor uniformidade morfogenética das suas unidades de mapeamento.

A Tabela 11 apresenta um resumo da base de dados originais do levantamento semidetalhado de solos (Oliveira \& Prado, 1989) das unidades de mapeamento presentes 
Tabela 10- Resumo dos atributos do solo das unidades de mapeamento do mapa semidetalhado*

\begin{tabular}{|c|c|c|c|c|c|c|c|c|c|c|c|c|c|c|c|c|c|}
\hline nMapa $\mathrm{H}$ & Hor & Estat. & Obs. & Areia S & Silte & Arg. & $\mathrm{pH}$ & $\mathrm{MO}$ & $P$ & $\mathrm{~S}$ & CTC & Targ & V & $\mathrm{m}$ & IM1 & IM2 & IM3 \\
\hline & & & & & $\mathrm{g} \mathrm{kg}^{-1}$ & & $\mathrm{CaCl}_{2}$ & $\mathrm{~g} \mathrm{~kg}^{-1}$ & $\mathrm{mgkg}^{-1}$ & $\cdots-m$ & molc.k & $\mathrm{g}^{-1}-\ldots$ & -....-o" & 6 & & $--\%$ & \\
\hline \multirow[t]{6}{*}{ PV6 } & A & MÉDIA & 5 & 750 & 76 & 174 & 4.1 & 11 & 9 & 18 & 55 & 147 & 30 & 39 & & & \\
\hline & & $\mathrm{CV} \%$ & 5 & 18 & 22 & 84 & 4.1 & 36 & 149 & 89 & 73 & 65 & 30 & 55 & 57 & 64 & 42 \\
\hline & & UNIF \% & 5 & 53 & 65 & -26 & 67 & 33 & 56 & 10 & -22 & 27 & 36 & 45 & 25 & 19 & 22 \\
\hline & B & MÉDIA & 5 & 574 & 86 & 340 & 4.2 & 9 & 4 & 28 & 69 & 115 & 43 & 35 & & & \\
\hline & & $\mathrm{CV} \%$ & 5 & 16 & 19 & 31 & 12 & 47 & 31 & 39 & 38 & 72 & 24 & 63 & 43 & 48 & 34 \\
\hline & & UNIF \% & 5 & 59 & 69 & 17 & 11 & 27 & 86 & 48 & 3 & -17 & 55 & 26 & 28 & 26 & 23 \\
\hline \multirow[t]{6}{*}{ PV7 } & A & MĖDIA & 8 & 435 & 276 & 289 & 5.5 & 19 & 23 & 99 & 135 & 289 & 73 & 0 & & & \\
\hline & & $\mathrm{CV} \%$ & 8 & 40 & 33 & 38 & 8 & 27 & 91 & 53 & 41 & 53 & 17 & 283 & 68 & 71 & 72 \\
\hline & & UNIF \% & 8 & -4 & 48 & 43 & 35 & 51 & 73 & 46 & 32 & 40 & 63 & -185 & 17 & 15 & -7 \\
\hline & B & MÉDIA & 8 & 2962 & 209 & 495 & 4.8 & 16 & 6 & 73 & 135 & 182 & 56 & 10 & & & \\
\hline & & $\mathrm{CV} \%$ & 8 & 34 & 42 & 16 & 16 & 16 & 149 & 37 & 34 & 39 & 30 & 99 & 57 & 56 & 36 \\
\hline & & UNIF \% & 8 & 15 & 32 & 58 & -21 & 75 & 35 & 50 & 12 & 38 & 43 & -17 & 18 & 20 & 23 \\
\hline \multirow[t]{6}{*}{ PV9 } & A & MÉDIA & 115 & 670 & 165 & 165 & 4.4 & 16 & 6 & 30 & 67 & 195 & 39 & 28 & & & \\
\hline & & $\mathrm{CV} \%$ & 115 & 31 & 67 & 65 & 13 & 60 & 159 & 115 & 59 & 105 & 51 & 76 & 77 & 74 & 55 \\
\hline & & UNIF \% & 115 & 20 & -5 & 2 & -0.6 & -10 & 53 & -17 & 1 & -19 & -8 & 24 & & & 3 \\
\hline & B & MÉDIA & 106 & 517 & 165 & 318 & 4.2 & 12 & 4 & 35 & 97 & 211 & 37 & 47 & & & \\
\hline & & $\mathrm{CV} \%$ & 106 & 32 & 62 & 34 & 10 & 73 & 242 & 73 & 36 & 62 & 56 & 60 & 73 & 69 & 41 \\
\hline & & UNIF \% & 106 & 19 & -2 & 10 & 22 & -15 & -6 & ( & 9 & -1 & -6 & & 6 & 6 & 9 \\
\hline PV7+ & A & MÉDIA & 52 & 768 & 105 & 127 & 4.4 & 14 & 11 & 22 & 57 & 197 & 37 & 23 & & & \\
\hline \multirow[t]{5}{*}{ Li5 } & & $\mathrm{CV} \%$ & 52 & 13 & 39 & 57 & 8.1 & 58 & 135 & 68 & 39 & 81 & 38 & 87 & 78 & 58 & 46 \\
\hline & & UNIF \% & 52 & 66 & 39 & 14 & 36 & -7 & 60 & 31 & 34 & 9 & 20 & 12 & 20 & 29 & 20 \\
\hline & B & MÉDIA & 52 & 609 & 105 & 286 & 4.4 & 10 & 3 & 32 & 87 & 236 & 39 & 41 & & & \\
\hline & & CV \% & 52 & 17 & 52 & 29 & 13 & 71 & 44 & 58 & 27 & 65 & 59 & 81 & 75 & 50 & 42 \\
\hline & & UNIF \% & 52 & 57 & 15 & 23 & 0 & -11 & 81 & 22 & 30 & -6 & -11 & 4 & 10 & 20 & 11 \\
\hline \multirow[t]{6}{*}{ TEP } & A & MÉDIA & 12 & 485 & 230 & 285 & 4.8 & 19 & 28 & 46 & 84 & 127 & 49 & 14 & & & \\
\hline & & CV\% & 12 & 39 & 31 & 56 & 13 & 58 & 145 & 84 & 49 & 62 & 43 & 161 & 68 & 71 & 60 \\
\hline & & UNIF \% & 12 & -2 & 51 & 16 & -8 & -6 & 57 & 14 & 18 & 29 & 10 & -62 & 7 & 10 & -1 \\
\hline & B & MÉDIA & 12 & 318 & 207 & 475 & 5.1 & 15 & 16 & 61 & 87 & 108 & 68 & 4 & & & \\
\hline & & $\mathrm{CV} \%$ & 12 & 40 & 38 & 28 & 11 & 42 & 225 & 46 & 29 & 49 & 21 & 188 & 72 & 73 & 54 \\
\hline & & UNIF \% & 12 & -2 & 38 & 25 & 20 & 34 & 2 & 38 & 27 & 20 & 60 & -121 & 6 & 5 & -3 \\
\hline \multirow[t]{6}{*}{ Li3 } & A & MÉDIA & 49 & 355 & 316 & 329 & 4.7 & 17 & 19 & 64 & 118 & 231 & 53 & 11 & & & \\
\hline & & $\mathrm{CV} \%$ & 49 & 59 & 33 & 40 & 12 & 37 & 101 & 59 & 42 & 68 & 39 & 172 & 71 & 76 & 63 \\
\hline & & UNIF \% & 49 & -52 & 49 & 39 & 7 & 31 & 70 & 40 & 29 & 24 & 17 & -73 & 6 & 7 & -7 \\
\hline & CR & MÉDIA & 46 & 306 & 270 & 424 & 4.6 & 13 & 11 & 67 & 128 & 233 & 53 & 20 & & & \\
\hline & & $\mathrm{CV} \%$ & 46 & 58 & 37 & 35 & 13 & 44 & 147 & 63 & 39 & 50 & 45 & 119 & 65 & 66 & 51 \\
\hline & & UNIF \% & 46 & -47 & 39 & 5 & 2 & 31 & 36 & 14 & 0 & 19 & 15 & -40 & 2 & 2 & -8 \\
\hline \multirow[t]{2}{*}{ Li6+TE } & A & Amostra & 1 & 410 & 220 & 370 & 5.3 & 32 & 58 & 126 & 187 & 280 & 67 & 0 & & & \\
\hline & C & Amostra & 1 & 190 & 120 & 690 & 5.8 & 11 & 5 & 102 & 136 & 155 & 75 & 0 & & & \\
\hline $\mathrm{Li} 1+\mathrm{Li} 2$ & A & MÉDIA & 3 & 737 & 157 & 107 & 5.0 & 17 & 309 & 68 & 95 & 429 & 61 & 6 & & & \\
\hline \multirow[t]{5}{*}{ + PV11 } & & $\mathrm{CV} \%$ & 3 & 3 & 16 & 29 & 11 & 71 & 130 & 96 & 72 & 57 & 40 & 173 & 57 & 70 & 50 \\
\hline & & UNIF \% & 3 & 93 & 75 & 57 & 13 & -31 & 62 & 2 & -22 & 36 & 16 & -74 & 29 & 20 & 21 \\
\hline & B & MÉDIA & 3 & 573 & 127 & 300 & 4.8 & 8 & 17 & 48 & 79 & 205 & 58 & 10 & & & \\
\hline & & CV\% & 3 & 13 & 24 & 19 & 14 & 60 & 153 & 60 & 27 & 37 & 36 & 173 & 48 & 52 & 46 \\
\hline & & UNIF \% & 3 & 67 & 60 & 50 & -5 & 5 & 33 & 18 & 30 & 40 & 33 & -104 & 25 & 26 & 14 \\
\hline
\end{tabular}

*Amostragem georeferenciada do levantamento detalhado de solos-2000 sobreposta ao mapa semidetalhado.

Obs.- Número de pertis amostrados; Arg.- Argila; MO- Matéria orgânica; P. Fósforo; S- Soma de bases; TargAtividade da argila; V- Saturação por bases; m- Saturação por alumínio; e IM- Índice Médio. 


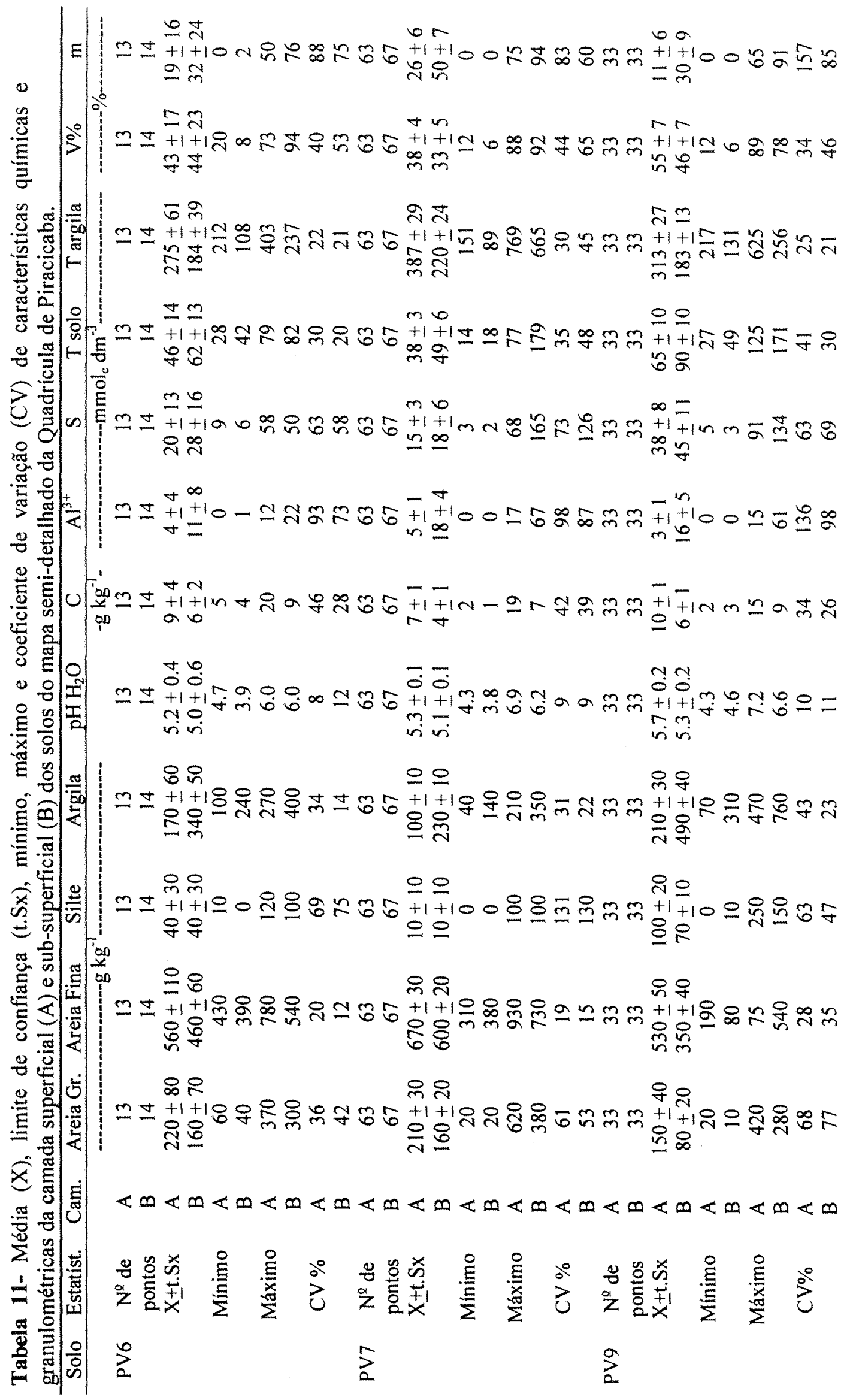




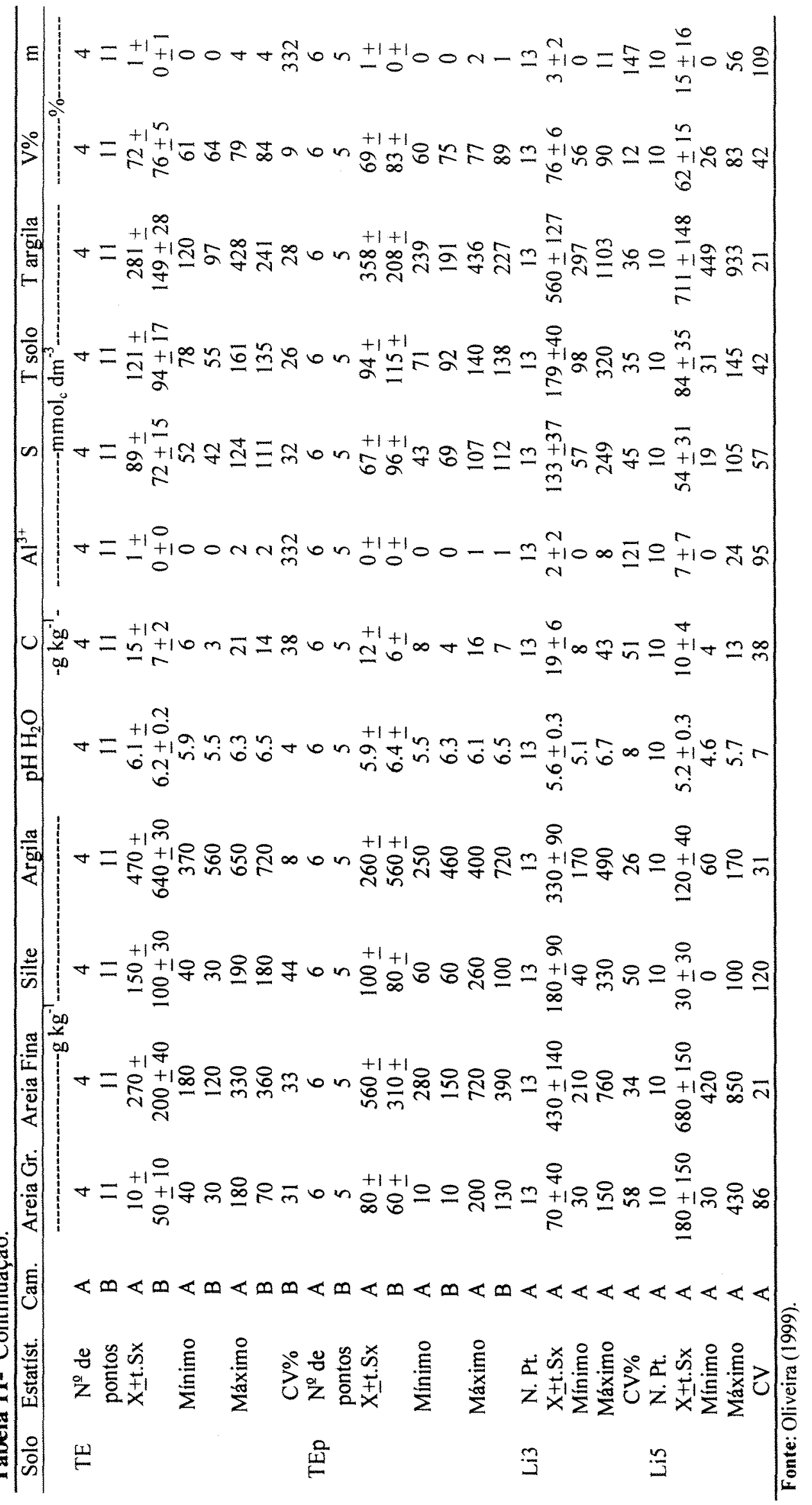


na microbacia hidrográfica do Córrego do Ceveiro. Esses valores são representativos dessas unidades em toda a Quadrícula de Piracicaba. Observa-se a alta variabilidade dos atributos do solo textura, CTC do solo, atividade da argila, saturação por bases e saturação por alumínio, tanto no horizonte A como no horizonte subsuperficial B.

Comparando-se as duas bases de dados do mapa semidetalhado de solos (Tabela 11 - base de dados originais (Oliveira \& Prado, 1989) e Tabela 10 - banco de dados da amostragem do levantamento detalhado de 2000, já discutido) para as unidades de mapeamento PV6, PV7, PV9, TEp e Li3, comuns a ambas, podemos observar que a variabilidade da atividade da argila é maior na amostragem do mapa de 2000 do que na base de dados originais.

Tomando como exemplo apenas a unidade de mapeamento PV9 (com amostragem bastante representativa), para comparar a variabilidade de alguns atributos dos solos entre as duas bases de dados (Tabela 11 e Tabela 10) verifica-se que a textura e a saturação com alumínio apresentam variabilidade maior na base de dados originais, enquanto que a atividade da argila e a saturação por bases apresentam variabilidade maior na amostragem do mapa de 2000.

Comparando-se as unidades de mapeamento, utilizando a base de dados georeferenciados do levantamento detalhado de solos-2000 sobre o mapa semidetalhado (Tabela 10), observa-se que no horizonte $\mathrm{A}$ as unidades que apresentam menores variabilidades, de acordo com os índices médios, são: IM1 (coeficiente de variação médio geral) - Lil +Li2 +PVI1; IM2 (coeficiente de variação médio geral reduzido) $P V 7+L i 5$; e IM3 (coeficiente de variação médio para classificação) - PV6, sendo que a unidade de mapeamento PV6 apresenta os menores índices no conjunto dos três índices médios. Considerando o horizonte $\mathrm{B}$ a unidade $P V 6$ apresenta os menores valores nos três índices médios.

Analisando-se o CV\% médio ponderado do mapa semidetalhado (Tabela 8) observa-se, no horizonte $\mathrm{A}$, que os atributos de menor variabilidade (grupo I) são os valores de $\mathrm{pH}$, enquanto os de maior variabilidade (grupo III), são: areia muito grossa, 
areia grossa, areia média, fósforo, potássio, cálcio, magnésio, alumínio, soma de bases, atividade de argila e saturação por alumínio, além dos índices médios IM1 e IM2.

Observa-se, de modo geral, uma maior variabilidade, tanto na camada superficial A como na subsuperficial B, no mapa semidetalhado em relação ao mapa detalhado2000 e mapa detalhado-1991. Estes resultados mostram uma redução da variância dos atributos de solos com o detalhamento dos mapas de solos, como observados em Beckett \& Burrough (1971), Beckett \& Webster (1971) e Marsman \& Gruijter (1986).

\subsubsection{Variabilidade do solo a curta distância - "Grid"}

Visando conhecer a variabilidade dos atributos de solos em curta distância, das 59 observações do "grid" foram selecionadas 51 observações localizada na unidade de mapeamento $A C t 2$ (associação complexa de ALISSOLOS CRÔMICOS Argilúvicos abrúpticos + ARGISSOLOS VERMELHO-AMARELOS Alumínicos abrúpticos ambos A moderado textura arenosa/média) do mapa detalhado de solos-2000.

Analisando-se os coeficientes de variação do "grid" (subamostra) apresentados na Tabela 12 e Anexo D, nota-se que a menor variabilidade é para os atributos areia total e pH em média $10 \%$; enquanto a maior variabilidade é para concentração de fósforo com valor maior que $80 \%$. Os atributos que fazem parte do grupo I (menor variabilidade), são: horizonte $\mathrm{A}$ - conteúdo de areia total e silte; $\mathrm{pH}$, CTC do solo, saturação por bases, IM1 (índice médio de todos os atributos), e IM3 (índice médio para atributos importantes para classificação); e horizonte B - conteúdo de areia total e argila; pH, CTC do solo, e IM3. Os atributos que fazem parte do grupo III - maior variabilidade, são: horizonte A - concentração de fósforo; e saturação por alumínio; horizonte B - conteúdo de areia muito grossa e areia grossa; concentração de alumínio.

É importante ressaltar que mesmo no "Grid", com amostras coletadas a curtas distâncias, a variância $(\mathrm{CV} \%)$ do teor de matéria orgânica no horizonte $\mathrm{A}$ é maior que na área total (microbacia como um todo), apresentado na Tabela 12; e no horizonte B o mesmo acontece com o conteúdo de areia muito grossa, $\mathrm{pH} \mathrm{em} \mathrm{H}_{2} \mathrm{O}, \%$ de floculação da argila, teor de matéria orgânica, e saturação por bases. Estes resultados sugerem que 
grande parte da variância total na área de estudo consiste em variância de pequenas distâncias.

Tabela 12- Resumo dos atributos do solo da área do "grid" e da microbacia (MHCC).

\begin{tabular}{|c|c|c|c|c|c|c|c|c|c|c|c|c|c|c|c|c|c|}
\hline UnMapa & Hor & Estat. & Obs. & Areia & Silte & Arg. & $\mathrm{pH}$ & MO & $\mathrm{P}$ & $\mathrm{S}$ & CTC & Targ & V & $\mathrm{m}$ & IM1 & $\mathrm{IM} 2$ & IM3 \\
\hline & & & & $-\ldots$ & $\mathrm{g} \mathrm{kg}^{-1}$ & $-\ldots$ & $\mathrm{CaCl}_{2}$ & $\mathrm{~g} \mathrm{~kg}^{-1}$ & $\mathrm{mgkg}^{-1}$ & $\cdots-m$ & molc. & $\mathrm{kg}^{-1}-\ldots$ & $---0 \%$ & - & -.-- & $-\%$ & $\ldots$ \\
\hline \multirow[t]{6}{*}{ "GRID" } & A & MÉDIA & 51 & 790 & 94 & 115 & 4,2 & 13 & 5 & 17 & 52 & 197 & 32 & 30 & & & \\
\hline & & CV \% & 51 & 9 & 28 & 45 & 8 & 58 & 102 & 58 & 28 & 67 & 33 & 71 & 39 & 45 & 37 \\
\hline & & UNIF \% & 51 & 78 & 56 & 32 & 34 & -6 & 70 & 41 & 52 & 24 & 30 & 29 & 43 & 41 & 32 \\
\hline & B & MÉDIA & 50 & 610 & 102 & 287 & 4,3 & 10 & 2 & 30 & 82 & 206 & 38 & 46 & & & \\
\hline & & $\mathrm{CV} \%$ & 50 & 12 & 43 & 23 & 12 & 69 & 42 & 55 & 19 & 59 & 55 & 66 & 58 & 43 & 36 \\
\hline & & UNIF \% & 50 & 70 & 29 & 38 & 12 & -9 & 82 & 25 & 52 & 4 & -4 & 22 & 23 & 30 & 22 \\
\hline \multirow[t]{4}{*}{ MHCC } & A & MÉDIA & 245 & 612 & 188 & 200 & 4,5 & 16 & 15 & 39 & 79 & 205 & 43 & 22 & & & \\
\hline & & CV\% & 245 & 39 & 64 & 66 & 13 & 54 & 339 & 98 & 59 & 89 & 47 & 99 & 84 & 88 & 57 \\
\hline & $\mathrm{B}$ & MÉDIA & 233 & 479 & 174 & 348 & 4,4 & 12 & 6 & 44 & 101 & 212 & 44 & 36 & & & \\
\hline & & $\mathrm{CV} \%$ & 233 & 40 & 61 & 37 & 13 & 64 & 229 & 74 & 39 & 62 & 53 & 85 & 73 & 72 & 46 \\
\hline
\end{tabular}

Obs.- Número de perfis amostrados; Arg.- Argila; MO- Matéria orgânica; P- Fósforo; S- Soma de bases; TargAtividade da argila; V-Saturação por bases; m-Saturação por alumínio; e IM- Índice Médio.

A microbacia hidrográfica do Córrego do Ceveiro apresenta histórico de intensa erosão (Sparovek et al., 1997; Sparovek, 1998). A quantificação e mapeamento dos processos erosivos utilizam como ferramenta modelos de predição de Erosão, como por exemplo, a Equação Universal de Perda de Solo (Universal Soil Loss Equation- USLE) (Wischmeier \& Smith, 1978). Um dos parâmetros da USLE é o fator erodibilidade dos solos $(K)$, que leva em consideração a classe dos solos e alguns atributos. Em áreas onde uma elevada variância de curta distância é evidente, o mapeamento do solo torna-se pouco eficiente, trazendo possibilidades de erros na interpretação dos resultados desse modelo.

A amostragem ao acaso pode, em alguns casos, falhar em detectar variabilidade elevadas de atributos no solo, como observou Vieira (1997) com atributos químicos do solo, trabalhando em um "grid" de 30 x 30 m e amostragem de $5 \mathrm{em} 5 \mathrm{~m}$.

Variabilidade em curtas distâncias, como por exemplo: material de origem; topografia; erosão do solo; atividades biológicas; e processos físico-químicos dentro do solo, foram citadas por Beckett \& Webster (1971). Os efeitos destas fontes ocorrem simultaneamente, podendo haver ou não dominância de um sobre o outro. 
A variação dos atributos do solo, também, está associada aos fatores naturais como energia envolvida nos processos responsáveis pela distribuição e disposição do material no ambiente (Drees \& Wilding, 1973), retrabalhamento (Nott et al., 1994), e a fatores que influenciam a chamada dinâmica local, como pequenas dobras no relevo, atividade biológica, ocorrência de camadas de rochas impermeáveis a água, etc, dentro da mesma formação geológica. Entre as causas de variações locais, Brinkmann (1970) citou a ocorrência de ferrólise, enquanto lixiviação, acúmulo e/ou decomposição de matéria orgânica foram observados por Berg et al. (1987). Diferenças fundamentais quanto aos solos formados foram verificadas por Chagas et al. (1997), como consequência da disposição das camadas de rochas na horizontal ou inclinadas.

Os processos que dão origem a diferenças de solos em distâncias muito curtas introduzem variabilidade dentro de todas as áreas amostrada independente do seu tamanho.

Apesar da variabilidade do solo (medido por CV\%) aumentar com o tamanho da área amostrada, Beckett \& Webster (1971) concluíram que muito da variabilidade presente em uma área, ou na paisagem como um todo, já está presente dentro de áreas de 1 a $100 \mathrm{~m}^{2}$.

Em suma, de acordo com os dados obtidos e trabalhos discutidos, há pouca eficiência de mapeamento em escalas onde uma elevada variância de curta distância fica evidente.

\subsubsection{Comparação da variabilidade entre os mapas de solos}

A comparação da variabilidade entre os mapas de solos foi feita utilizando-se a média ponderada dos CV\% dos atributos do solo para cada um dos três mapas de solos em estudo (Tabela 8). Além das médias ponderadas dos CV\% para os mapas detalhado2000, detalhado-1991 e semidetalhado, são apresentados também os CV\% da subamostra do "grid" (Grid) e o coeficiente de variação de todas as amostras da microbacia em estudo (Geral). São apresentados também os índices de uniformidade desses mapas e do Grid. 
Ao comparar apenas os mapas, a variância (medida através do coeficiente de variação) do mapa detalhado-2000 é menor, no horizonte $\mathrm{A}$, para quase todos os atributos de solos e para os três índices médios, com exceção da \% de floculação da argila, concentração de $\mathrm{H}+\mathrm{Al}$ e saturação por alumínio (m).

Em relação ao horizonte $\mathrm{B}$, o mapa detalhado de solos-2000 apresenta menor variabilidade em 15 dos 24 atributos de solos e índice médio IM2. Enquanto que o mapa detalhado-1991 apresenta menores valores de CV\% em 8 atributos de solos e índices médios IM1 e IM3. O mapa semidetalhado apresenta menor variabilidade apenas para o atributo concentração de alumínio (Tabela 8).

Considerando-se a subamostra do grid na comparação com os mapas, nota-se que o grid apresenta menores valores de coeficiente de variação, no horizonte A, para 17 atributos de solos e para os três índices médios; enquanto os outros 7 atributos de solos têm menores valores no mapa detalhado-2000. No horizonte B (horizonte subsuperficial) o grid continua com os menores valores de CV\% para 14 atributos de solos e para os índices médios IM1, IM2 e IM3; enquanto o mapa detalhado-2000 apresenta os menores CV\% para 8 atributos de solos, e o mapa detalhado-1991 possui valores mais baixos de $\mathrm{CV} \%$ para os atributos areia muito grossa e $\mathrm{pH} \mathrm{em} \mathrm{H}_{2} \mathrm{O}$.

Observa-se que alguns atributos do solo, pH, Matéria orgânica, $\mathrm{P}$ e saturação por bases, que são atributos bastante influenciados pelo manejo, apresentam menor variabilidade no horizonte A (ou horizonte superficial) do que no horizonte B (ou horizonte subsuperficial) em todos os mapas e no grid. Esta menor variação desses atributos pode ser explicada pelo manejo intensivo da cultura de cana-de-açúcar, explorada por vários anos na microbacia (Fiorio, 1998), que estaria tendendo a uniformizar a parte superficial do solo.

Por outro lado, os atributos utilizados como base para classificação de solos no sistema antigo (Embrapa, 1988) e atual (Embrapa, 1999), teor de argila, atividade da argila e saturação por alumínio, apresentam menor variação no horizonte subsuperficial (B) do que no horizonte superficial (A) em todos os mapas e no grid. A menor variação 
é causada pelo maior uniformidade, desses atributos, dentro das unidades de mapeamento.

Os atributos granulométricos, os quais são pouco influenciáveis pelo manejo, apresentam menor variação do que os atributos químicos, os quais são mais facilmente influenciáveis pelos manejo, tanto no horizonte superficial (A) como no horizonte subsuperficial (B) em todos os mapas e no grid. Estes resultados concordam com aqueles obtidos por Berg \& Klamt (1997a e 1997b) e Oliveira (1999).

Marsman \& Gruijter (1986) concluíram que as variâncias das propriedades de solo, dentro das unidades de mapeamento dos mapas de solos 1:10.000, não são muito menores que aquelas dos mapas de solos 1:50.000, apesar do maior detalhe de mapeamento e densidade de observação mais alta. Os autores sugerem de acordo com os seus resultados, como já foi mencionado anteriormente, que grande parte da variância total na área de estudo consiste em variâncias de pequena distância.

Os resultados mostram que ocorrem reduções significativas da variância, medida através do coeficiente de variação, dos atributos de solos do mapa semidetalhado de solos, escala 1:100.000, para os mapas detalhado-2000 e detalhado-1991, escala 1:10.000. Também, ocorrem diferenças entre os dois mapas detalhados de solos-2000 e 1991 executados por diferentes equipes de pedologia. A variância média do mapa detalhado-2000 é menor que a do mapa detalhado-1991. Bie e Beckett (1973), comparando os mapas de solos executados por quatro diferentes pedólogos, demonstraram que a variância de algumas propriedades de solos, tanto para unidades de mapeamento como para unidades de classificação, eram diferentes nos quatro mapas. Esses autores concluíram que os quatro mapas de solos produzidos por interpretação de fotografias aéreas demonstram que a experiência do pedólogo influencia na percepção da mesma paisagem de solos. E então eles podem definir diferentes classes de solos de unidades de mapeamento para a mesma população de solos. Suas diferenças refletem a qualidade de seus mapas.

É importante ressaltar a elevada variabilidade da saturação por alumínio, atributo utilizado para diferenciação de classes de solos ao nível de ordem no Sistema Brasileiro 
de Classificação de solos (Embrapa, 1999), que apresenta valores de CV\% maiores para todos os mapas em relação a área total, tanto no horizonte A como no horizonte B. Observa-se, também, que outros atributos importantes para classificação de solos no nosso sistema de classificação, tais como, atividade da argila e saturação por bases, apresentam elevada variância em curtas distâncias. Isto corrobora a dificuldade na Microbacia Hidrográfica do Córrego do Ceveiro em separar algumas unidades de mapeamento, que são associações complexas, em unidades simples, principalmente em relação à atividade da argila, saturação por bases e saturação por alumínio.

Como já visto anteriormente, uma parte importante da variância total dentro da área da microbacia provavelmente consiste em variância a pequenas distâncias. Isto restringe as possibilidades de aumentar a precisão e acurácia de mapas de solo nas escalas 1:10.000. Também, neste caso, o aumento da densidade de observação ou a escala do mapa terá pequeno efeito na qualidade do mapa, apesar do mapa detalhado, escala 1:10.000, apresentar menor variabilidade, isto é, ser mais precisos.

Decisões mais racionais sobre escala do mapa, densidade de observação e legenda do mapa, poderiam ser tomadas quando o levantamento de solos for precedido por investigações na variabilidade espacial das propriedades de solo, tal como enfatizado por Burrough (1983).

\subsubsection{Teste t para comparação entre unidades de mapeamento nos mapas de solos}

Os mapas de solos também foram comparados através do teste $\mathrm{t}$ com a comparação de alguns atributos do solo entre as unidades de mapeamento (duas a duas) dentro de cada mapa de solos.

\section{a) Mapa detalhado de solos-2000}

Ao analisar a Tabela 13, que apresenta os resultados resumidos do teste $t$ para algumas unidades de mapeamento e alguns atributos do mapa detalhado de solos-2000, podemos observar inicialmente que nem todas as unidades apresentam diferenças estatísticas entre si. 
Chama atenção a diferença significativa a $1 \%$ para os 5 atributos observados, ou seja, conteúdo de argila no horizonte A (ArgA), conteúdo de argila no horizonte B (ArgB), atividade de argila no horizonte B (Targ), saturação por bases no horizonte B (V\%) e saturação por alumínio no horizonte B (m), que existe entre as unidades ACt1 e $\mathrm{ACt} 2$ versus PVAe3. Esta diferença seria esperada já que as unidades $\mathrm{ACt} 1$ e $\mathrm{ACt} 2$ são composta de solos (ALISSOLOS CRÔMICOS) que apresentam horizonte B textural, textura areia/média, alta atividade da argila e saturação por alumínio alta (alumínicos), enquanto os solos da unidade PVAe3 (ARGISSOLOS VERMELHO-AMARELOS) apresentam horizonte $\mathrm{B}$ textural, textura média/argilosa, baixa atividade da argila $\mathrm{e}$ saturação por bases alta (eutróficos).

Entre as unidades que apresentam horizonte $\mathrm{B}$ textural e horizonte $\mathrm{A}$ arênico (ACtq, PVAeq, PVAdq e TCpq) ocorrem diferenças significativas, a 5\%, entre as unidades TCpq e PVAeq vs. ACtq somente para saturação por alumínio, que seria esperado; já que as duas primeiras são eutróficos e a última é alumínico. Entre ACtq vs. PVAdq, ocorre diferença significativa, a 5\%, para atividade da argila (Targ). A unidade de mapeamento ACtq apresenta atividade da argila alta e baixa e PVAdq atividade da argila baixa. Não ocorrem diferenças significativas entre as unidades de mapeamento TCpq, PVAeq e PVAdq, estas unidades apresentam diferenças em atividade da argila e saturação por bases, porém não são significativas. As unidades PVAeq e PVAdq apresentam uniformidade negativa (isto é, o coeficiente de variação é maior nessas unidades que na área como um todo), o que reduz a significância.

Comparando as unidades que apresentam pouca profundidade ou lépticos (ACtl1, ACt12, PVAel2, TCol2 e CXvbe) ocorrem diferenças esperadas entre todas as unidades, para atributos importantes de diferenciação, com exceção da comparação entre PVAel2 vs. TCol2, que são associação de unidades que apresentam atividade de argila alta e baixa e saturação por bases alta. 
Tabela 13- Teste $t$ entre os parâmetros teor de argila no horizonte A (Arg A), teor de argila no horizonte B (subsuperficial) (Arg B), atividade da argila no B (Targ), saturação de bases no $B(V \%)$ e saturação de alumínio no $B(m)$ entre classes de solos do mapa detalhado de solos-2000, com mais de 3 observações por unidade de mapeamento.

\begin{tabular}{|c|c|c|c|c|c|c|c|c|c|c|c|c|c|c|c|c|c|c|}
\hline Classe & Obs & & $\mathrm{ACtl}$ & $\mathrm{AC2}$ & $\mathrm{ACt} 4$ & ACta & ACUI & $\overline{\mathrm{ACH}}$ & \begin{tabular}{|l|} 
PVAa1 \\
\end{tabular} & PVAe3 & PVAdq & $\begin{array}{l}\text { PVAeq } \\
\end{array}$ & PVAel2 & PVe & TCpq & $\mathrm{TCO} 2$ & NVe & CXvbe \\
\hline \multirow[t]{5}{*}{$\mathrm{ACt1}$} & 6 & $\mathrm{ArgA}$ & & $"$ & ns & & & & ns & ** & & & & ns & & & & \\
\hline & 6 & $\mathrm{ArgB}$ & & $* *$ & $*$ & & & & $* *$ & ** & & & & * & & & & \\
\hline & 6 & Targ & & ns & $\mathrm{ns}$ & & & & ** & $* *$ & & & & * & & & & \\
\hline & 6 & $\mathrm{~V} \%$ & & ns & $\mathrm{ns}$ & & & & ns & ** & & & & $* *$ & & & & \\
\hline & 6 & $\mathrm{~m}$ & & ns & $\mathrm{ns}$ & & & & $\mathrm{ns}$ & ** & & & & $* *$ & & & & \\
\hline \multirow[t]{5}{*}{$\mathrm{ACt} 2$} & 81 & ArgA & $"$ & & ns & & & & ns & ** & & & & ns & & & & \\
\hline & 82 & ArgB & $* *$ & & $"$ & & & & $*$ & $* *$ & & & & 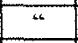 & & & & \\
\hline & 82 & Targ & ns & & $\mathrm{ns}$ & & & & $*$ & ** & & & & $" 6$ & & & & \\
\hline & 82 & $\mathrm{~V} \%$ & ns & & ** & & & & ns & $* *$ & & & & *** & & & & \\
\hline & 82 & $\mathrm{~m}$ & ns & & ns & & & & ns & ** & & & & $* *$ & & & & \\
\hline \multirow[t]{5}{*}{$\mathrm{ACt} 4$} & 3 & ArgA & ns & ns & & & & & ns & ns & & & & ns & & & & \\
\hline & 3 & $\mathrm{ArgB}$ & * & $"$ & & & & & ns & ns & & & & ns & & & & \\
\hline & 3 & Targ & ns & ns & & & & & "* & ns & & & & " & & & & \\
\hline & 3 & $\mathrm{~V} \%$ & ns & *** & & & & & ns & ** & & & & ** & & & & \\
\hline & 3 & $\mathrm{~m}$ & ns & ns & & & & & $\mathrm{ns}$ & $\mathrm{ns}$ & & & & ns & & & & \\
\hline \multirow{5}{*}{ ACtq } & 3 & ArgA & & & & & & & & & ns & ns & & & ns & & & \\
\hline & 3 & ArgB & & & & & & & & & ns & $\mathrm{ns}$ & & & $\mathrm{ns}$ & & & \\
\hline & 3 & Targ & & & & & & & & & $*$ & ns & & & ns & & & \\
\hline & 3 & $\mathrm{~V} \%$ & & & & & & & & & ns & ns & & & ns & & & \\
\hline & 3 & $\mathrm{~m}$ & & & & & & & & & ns & * & & & * & & & \\
\hline \multirow[t]{5}{*}{ ACtll } & 10 & $\operatorname{ArgA}$ & & & & & & Ns & & & & & $"$ & & & ** & & ** \\
\hline & 10 & ArgB & & & & & & "6 & & & & & * & & & * & & ** \\
\hline & 10 & Targ & & & & & & $\mathrm{Ns}$ & & & & & 4 & & & ns & & ns \\
\hline & 10 & V\% & & & & & & Ns & & & & & $*$ & & & “" & & $* *$ \\
\hline & 10 & $\mathrm{~m}$ & & & & & & Ns & & & & & ** & & & ** & & $* *$ \\
\hline \multirow[t]{5}{*}{$\mathrm{ACt} 2$} & 3 & $\operatorname{Arg} A$ & & & & & ns & & & & & & * & & & $* *$ & & ** \\
\hline & 3 & $\mathrm{ArgB}$ & & & & & $" 4$ & & & & & & ns & & & ns & & ns \\
\hline & 3 & Targ & & & & & ns & & & & & & $\mathrm{ns}$ & & & ns & & $\mathrm{ns}$ \\
\hline & 3 & $\mathrm{~V} \%$ & & & & & $\mathrm{~ns}$ & & & & & & $*$ & & & $*$ & & $* *$ \\
\hline & 3 & $\mathrm{~m}$ & & & & & ns & & & & & & * & & & ** & & ** \\
\hline \multirow[t]{5}{*}{ PVAal } & 4 & $\operatorname{Arg} A$ & ns & $\mathrm{ns}$ & $\mathrm{ns}$ & & & & & $* *$ & & & & ns & & & & \\
\hline & 4 & ArgB & $* *$ & $*$ & ns & & & & & ns & & & & ns & & & & \\
\hline & 4 & Targ & ** & $*$ & " & & & & & ns & & & & ns & & & & \\
\hline & 4 & $V \%$ & ns & ns & ns & & & & & * & & & & $* *$ & & & & \\
\hline & 4 & $\mathrm{~m}$ & ns & ns & $\mathrm{ns}$ & & & & & ns & & & & $"$ & & & & \\
\hline \multirow[t]{5}{*}{ PVAe3 } & 10 & $\operatorname{ArgA}$ & ** & ** & ns & & & & ** & & & & & ns & & & & \\
\hline & 10 & $\overline{A r g B}$ & $* *$ & ** & $\mathrm{ns}$ & & & & $\mathrm{ns}$ & & & & & ns & & & & \\
\hline & 10 & Targ & ** & $* *$ & $\mathrm{~ns}$ & & & & ns & & & & & ns & & & & \\
\hline & 10 & $\mathrm{~V} \%$ & ** & ** & $* *$ & & & & $*$ & & & & & $*$ & & & & \\
\hline & 10 & $\mathrm{~m}$ & ** & ** & $\mathrm{ns}$ & & & & ns & & & & & * & & & & \\
\hline \multirow[t]{5}{*}{ PVAdq } & 4 & ArgA & & & & ns & & & & & & $\mathrm{ns}$ & & & ns & & & \\
\hline & 4 & $\mathrm{ArgB}$ & & & & ns & & & & & & ns & & & ns & & & \\
\hline & 4 & Targ & & & & $*$ & & & & & & ns & & & $\mathrm{ns}$ & & & \\
\hline & 4 & $\mathrm{~V} \%$ & & & & ns & & & & & & ns & & & ns & & & \\
\hline & 4 & $\mathrm{~m}$ & & & & ns & & & & & & ns & & & ns & & & \\
\hline \multirow[t]{5}{*}{ PVAeq } & 4 & $\operatorname{Arg} A$ & & & & ns & & & & & ns & & & & ns & & & \\
\hline & 4 & ArgB & & & & ns & & & & & ns & & & & ns & & & \\
\hline & 4 & Targ & & & & ns & & & & & ns & & & & ns & & & \\
\hline & 4 & $\mathrm{~V} \%$ & & & & ns & & & & & ns & & & & ns & & & \\
\hline & 4 & $\mathrm{~m}$ & & & & * & & & & & ns & & & & ns & & & \\
\hline \multirow[t]{5}{*}{ PVAel2 } & 3 & ArgA & & & & &. & $*$ & & & & & & & & ns & & \\
\hline & 3 & $\mathrm{ArgB}$ & & & & & $*$ & ns & & & & & & & & $\mathrm{ns}$ & & \\
\hline & 3 & Targ & & & & & " & ns & & & & & & & & ns & & \\
\hline & 3 & $\mathrm{~V} \%$ & & & & & $*$ & $*$ & & & & & & & & $\mathrm{~ns}$ & & \\
\hline & 3 & $\mathrm{~m}$ & & & & & ** & * & & & & & & & & ns & & \\
\hline
\end{tabular}


Tabela 13- Continuação.

\begin{tabular}{|c|c|c|c|c|c|c|c|c|c|c|c|c|c|c|c|c|c|c|}
\hline Classe & Obs & & $\mathrm{ACt} 1$ & $\mathrm{ACt} 2$ & $\mathrm{ACt4}$ & ACtq & ACt1 & ACt2 & PVAal & PVAe3 & PVAdq & PVAed & PVAel2 & $\mathrm{PVe}$ & TCpq & TCo2 & $\mathrm{NVe}$ & CXube \\
\hline \multirow[t]{5}{*}{ PVe } & 3 & $\operatorname{Arg} A$ & ns & ns & ns & & & & ns & ns & & & & & & & "6 & \\
\hline & 3 & $\mathrm{ArgB}$ & \pm & $\because$ & ns & & & & ns & ns & & & & & & & ns & \\
\hline & 3 & Targ & $*$ & $\cdots$ & 4 & & & & ns & ns & & & & & & & ns & \\
\hline & 3 & $\mathrm{~V} \%$ & ** & ** & $* *$ & & & & ** & * & & & & & & & ns & \\
\hline & 3 & $\mathrm{~m}$ & ** & ** & as & & & & $"$ & * & & & & & & & ns & \\
\hline \multirow[t]{5}{*}{$\mathrm{rCp}$} & 3 & $\operatorname{ArgA}$ & & & & ns & & & & & ns & ns & & & & & & \\
\hline & 3 & $\mathrm{ArgB}$ & & & & ns & & & & & ns & ns & & & & & & \\
\hline & 3 & Targ & & & & ns & & & & & ns & ns & & & & & & \\
\hline & 3 & $V \%$ & & & & ns & & & & & ns & $\mathrm{ns}$ & & & & & & \\
\hline & 3 & $\mathrm{~m}$ & & & & * & & & & & ns & ns & & & & & & \\
\hline \multirow[t]{5}{*}{$\mathrm{TCo} 2$} & 6 & ArgA & & & & & ** & ** & & & & & ns & & & & & ** \\
\hline & 6 & ArgB & & & & & * & $\mathrm{ns}$ & & & & & ns & & & & & ns \\
\hline & 6 & Targ & & & & & ns & ns & & & & & $\mathrm{ns}$ & & & & & ns \\
\hline & 6 & $\mathrm{~V} \%$ & & & & & $" *$ & * & & & & & ns & & & & & $\mathrm{ns}$ \\
\hline & 6 & $m$ & & & & & ** & ** & & & & & $\mathrm{ns}$ & & & & & ns \\
\hline \multirow[t]{5}{*}{ NVe } & 3 & $\operatorname{ArgA}$ & & & & & & & & & & & & $"$ & & & & \\
\hline & 3 & ArgB & & & & & & & & & & & & ns & & & & \\
\hline & 3 & Targ & & & & & & & & & & & & ns & & & & \\
\hline & 3 & $\mathrm{~V} \%$ & & & & & & & & & & & & ns & & & & \\
\hline & 3 & $\mathrm{~m}$ & & & & & & & & & & & & ns & & & & \\
\hline
\end{tabular}

Tabela 13- Continuação.

\begin{tabular}{|c|c|c|c|c|c|c|c|c|c|c|c|}
\hline Classe & $\mathrm{Obs}$ & & $\mathrm{ACtll}$ & $\mathrm{ACtl} 2$ & $\mathrm{TCo} 2$ & CXvbe & RUbe & GX3 & RLel & RLe2 & RLe4 \\
\hline \multirow[t]{5}{*}{ CXvbe } & 12 & $\operatorname{ArgA}$ & ** & $* *$ & $* *$ & & & & $*$ & ns & ns \\
\hline & 12 & ArgB & ** & $\mathrm{Ns}$ & ns & & & & $*$ & ns & ns \\
\hline & 12 & Targ & $\mathrm{ns}$ & Ns & ns & & & & ns & ns & ns \\
\hline & 12 & $\mathrm{~V} \%$ & $* *$ & $* *$ & ns & & & & ns & ns & ns \\
\hline & 12 & $\mathrm{~m}$ & ** & ** & ns & & & & ns & ns & ns \\
\hline \multirow[t]{5}{*}{ RUbe } & 4 & ArgA & & & & & & ns & & & \\
\hline & 4 & ArgB & & & & & & ns & & & \\
\hline & 4 & Targ & & & & & & ns & & & \\
\hline & 4 & $\mathrm{~V} \%$ & & & & & & 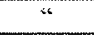 & & & \\
\hline & 4 & $\mathrm{~m}$ & & & & & & 4 & & & \\
\hline \multirow[t]{5}{*}{ GX3 } & 13 & $\operatorname{Arg} A$ & & & & & ns & & & & \\
\hline & 12 & ArgB & & & & & ns & & & & \\
\hline & 12 & Targ & & & & & ns & & & & \\
\hline & 12 & $\mathrm{~V} \%$ & & & & & $" \cdot$ & & & & \\
\hline & 12 & $\mathrm{~m}$ & & & & & $\cdots$ & & & & \\
\hline \multirow[t]{5}{*}{ RLel } & 13 & $\operatorname{ArgA}$ & & & & $*$ & & & & $* *$ & ** \\
\hline & 12 & ArgB & & & & 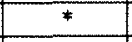 & & & & $"$ & +6 \\
\hline & 12 & Targ & & & & ns & & & & $\mathrm{ns}$ & $\mathrm{ns}$ \\
\hline & 12 & $\mathrm{~V} \%$ & & & & $\mathrm{~ns}$ & & & & ns & $\mathrm{ns}$ \\
\hline & 12 & $\mathrm{~m}$ & & & & ns & & & & ns & ns \\
\hline \multirow[t]{5}{*}{ RLe2 } & 8 & ArgA & & & & ns & & & $* *$ & & $\mathrm{~ns}$ \\
\hline & 7 & ArgB & & & & ns & & & 4 & & ns \\
\hline & 7 & Targ & & & & ns & & & ns & & $\mathrm{ns}$ \\
\hline & 7 & $\mathrm{~V} \%$ & & & & $\mathrm{~ns}$ & & & $\mathrm{~ns}$ & & ns \\
\hline & 7 & $\mathrm{~m}$ & & & & ns & & & $\mathrm{ns}$ & & ns \\
\hline \multirow[t]{5}{*}{ RLe4 } & 817 & ArgA & & & & ns & & & $* *$ & ns & ns \\
\hline & 14 & ArgB & & & & $\mathrm{ns}$ & & & 4 & ns & \\
\hline & 14 & Targ & & & & $\mathrm{ns}$ & & & ns & ns & \\
\hline & 14 & $\mathrm{~V} \%$ & & & & $\mathrm{~ns}$ & & & ns & ns & \\
\hline & 14 & $\mathrm{~m}$ & & & & ns & & & ns & ns & \\
\hline
\end{tabular}

ns - Médias não significantes.

" - Médias com significância ao nivel de 10\%

* - Médias com significância ao nível de 5\%.

** - Médias com significância ao nível de $1 \%$. 
Nas unidades de mapeamento RLe1, RLe2 e RLe4, representantes dos NEOSSOLOS LITÓLICOS, observa-se que apresentam diferenças significativas no conteúdo de argila do horizonte À e B, que são os atributos de diferenciação entre essas unidades. Na comparação entre RLe2 vs. RLe4 não ocorrem essas diferenças significativas, provavelmente por ser a unidade de mapeamento RLe4 uma associação de texturas argilosa e média, sendo que dominam solos de textura argilosa e a textura média é média argilosa (próxima da textura argilosa).

As unidades de mapeamento que apresentam maior homogeneidade (menores CV\%, Tabela 7) - ACt1, PVAel2, PVe e NVe, apresentam diferenças significativas com quase todas as outras unidades. PVe vs. NVe apresentam diferença significativa para textura no horizonte $\mathrm{A}$, que é junto com a diferença morfológica (presença do horizonte nitico na unidade NVe) o que as diferenciam.

Os dados evidenciam que as unidades de mapeamento do mapa detalhado de solos-2000, no geral e com poucas exceções, apresentam diferenças significativas entre elas para os atributos utilizados como diferenciadores para fins de descrição das unidades de mapeamento.

\section{b) Mapa detalhado de solos-1991}

Os resultados resumidos da avaliação das unidades de mapeamento através da comparação de médias pelo teste $t$, para o mapa detalhado de solos-1991, são apresentados na Tabela 14. As comparações utilizadas foram entre as unidades que apresentam horizonte B textural (Podzólicos), entre as duas unidades Podzólico pouco profundo e entre os solos pouco desenvolvidos (Solos Litólicos e Cambissolos).

Ressalta-se, inicialmente, que a unidade de mapeamento PV5 apresenta diferença significativa, para quase todos os atributos, com as unidades PV1, PV2, PV3 e PV4; esta diferença é esperada, pois as unidades apresentam texturas diferentes. Quando comparadas às unidades PV5 vs. PV6 e PV7, que apresentam textura média/argilosa, só ocorre diferença significativa entre PV5 vs. PV7 para saturação por bases, já que PV5 é eutrófico e PV7 é álico. 
Tabela 14- Teste $t$ entre os parâmetros teor de argila no horizonte $\mathrm{A}(\operatorname{Arg} \mathrm{A})$, teor de argila no horizonte B (subsuperficial) (Arg B), atividade da argila no B (Targ), saturação de bases no $B(V \%)$ e saturação de alumínio no $B(m)$ entre classes de solos do mapa detalhado de solos-1991. com mais de 3 observações por unidade de mapeamento.

\begin{tabular}{|c|c|c|c|c|c|c|c|c|c|c|c|c|c|c|c|}
\hline Classe & Obs & & PV1 & PV2 & PV3 & PV4 & PV5 & PV5pp & PV6 & PV7 & PV7pp & Lil & Li3 & $\mathrm{Li} 4$ & $\mathrm{Cb} 1$ \\
\hline \multirow[t]{5}{*}{ PV1 } & 11 & $\operatorname{ArgA}$ & & ns & ns & ns & ns & & $"=$ & $\mathrm{ns}$ & & & & & \\
\hline & 11 & $\mathrm{ArgB}$ & & ns & ns & $\mathrm{ns}$ & *** & & $"$ & $\mathrm{~ns}$ & & & & & \\
\hline & 11 & Targ & & “ & $*$ & " & ns & & $\mathrm{ns}$ & ns & & & & & \\
\hline & 11 & $\mathrm{~V} \%$ & & ns & $\mathrm{ns}$ & $*$ & $\mathrm{~ns}$ & & ns & ** & & & & & \\
\hline & 11 & $\mathrm{~m}$ & & $*$ & ns & * & $*$ & & ns & ns & & & & & \\
\hline \multirow[t]{5}{*}{ PV2 } & 96 & $\operatorname{Arg} A$ & ns & & ns & ns & ns & & " & $\mathrm{ns}$ & & & & & \\
\hline & 95 & $\mathrm{ArgB}$ & $\mathrm{ns}$ & & $*$ & ns & ** & & $*$ & $"$ & & & & & \\
\hline & 95 & Targ & $"$ & & ns & ns & is & & $\mathrm{ns}$ & ** & & & & & \\
\hline & 95 & $\mathrm{~V} \%$ & ns & & ns & ns & ** & & ns & $* *$ & & & & & \\
\hline & 95 & $\mathrm{~m}$ & $*$ & & ns & ns & ** & & ns & $*$ & & & & & \\
\hline \multirow[t]{5}{*}{ PV3 } & 31 & $\operatorname{ArgA}$ & ns & ns & & ns & $"$ & & " & ns & & & & & \\
\hline & 31 & ArgB & ns & $*$ & & $\mathrm{~ns}$ & ** & & " & ns & & & & & \\
\hline & 31 & Targ & $*$ & ns & & ns & $*$ & & ns & $* *$ & & & & & \\
\hline & 31 & $\mathrm{~V} \%$ & ns & ns & & $\because$ & ** & & $\mathrm{ns}$ & ** & & & & & \\
\hline & 31 & $\mathrm{~m}$ & ns & ns & & " & *** & & ns & $*$ & & & & & \\
\hline \multirow[t]{5}{*}{ PV4 } & 3 & $\operatorname{ArgA}$ & ns & ns & ns & & $"$ & & $*$ & ns & & & & & \\
\hline & 3 & $\mathrm{ArgB}$ & ns & ns & ns & & *** & & 4 & ns & & & & & \\
\hline & 3 & Targ & 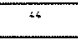 & $\mathrm{ns}$ & ns & 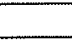 & " & & " & " & & & & & \\
\hline & 3 & $\mathrm{~V} \%$ & $*$ & ns & 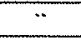 & & *** & & ns & ** & & & & & \\
\hline & 3 & $\mathrm{~m}$ & * & ns & $*$ & & ** & & ns & $* *$ & & & & & \\
\hline \multirow[t]{5}{*}{ PV5 } & 5 & $\operatorname{Arg} A$ & $\mathrm{~ns}$ & ns & ". & $"$ & & & ns & ns & & & & & \\
\hline & 5 & ArgB & $* *$ & $* *$ & ** & ** & & & $\mathrm{ns}$ & ns & & & & & \\
\hline & 5 & Targ & $\mathrm{ns}$ & “ & $*$ & " & & & ns & ns & & & & & \\
\hline & 5 & $\mathrm{~V} \%$ & ns & ** & $* *$ & *** & & & ns & $*$ & & & & & \\
\hline & 5 & $\mathrm{~m}$ & * & ** & 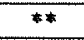 & ** & & & ns & ns & & & & & \\
\hline \multirow{5}{*}{ PV5pp } & 6 & ArgA & & & & & & & & & ns & & & & ns \\
\hline & 6 & $\mathrm{ArgB}$ & & & & & & & & & ns & & & & ns \\
\hline & 6 & Targ & & & & & & & & & $*$ & & & & ns \\
\hline & 6 & V\% & & & & & & & & & ns & & & & ns \\
\hline & 6 & $\mathrm{~m}$ & & & & & & & & & ns & & & & ns \\
\hline \multirow[t]{5}{*}{ PV6 } & 3 & $\operatorname{ArgA}$ & “ & " & $\cdots$ & $*$ & ns & & & “ & & & & & \\
\hline & 3 & ArgB & $"$ & $*$ & $*$ & " & ns & & & ns & & & & & \\
\hline & 3 & Targ & ns & $\mathrm{ns}$ & ns & “. & ns & & & $\mathrm{ns}$ & & & & & \\
\hline & 3 & $\mathrm{~V} \%$ & ns & ns & $\mathrm{ns}$ & $\mathrm{ns}$ & ns & & & ns & & & & & \\
\hline & 3 & $\mathrm{~m}$ & ns & ns & $\mathrm{ns}$ & ns & ns & & & ns & & & & & \\
\hline \multirow{5}{*}{ PV7 } & 3 & ArgA & ns & ns & ns & ns & $\mathrm{ns}$ & & *: & & & & & & \\
\hline & 3 & ArgB & ns & $"$ & ns & ns & ns & & $\mathrm{ns}$ & & & & & & \\
\hline & 3 & Targ & ns & *** & ** & $"$ & ns & & ns & & & & & & \\
\hline & 3 & $\mathrm{~V} \%$ & $* *$ & ** & $* *$ & *** & * & & ns & & & & & & \\
\hline & 3 & $\mathrm{~m}$ & ns & $*$ & * & ** & ns & & ns & & & & & & \\
\hline \multirow[t]{5}{*}{ PV7pp } & 6 & ArgA & & & & & & ns & & & & & & & ns \\
\hline & 6 & ArgB & & & & & & ns & & & & & & & $\mathrm{ns}$ \\
\hline & 6 & Targ & & & & & & $*$ & & & & & & & 16 \\
\hline & 6 & $\mathrm{~V} \%$ & & & & & & ns & & & & & & & $\mathrm{ns}$ \\
\hline & 6 & $\mathrm{~m}$ & & & & & & ns & & & & & & & ns \\
\hline \multirow[t]{5}{*}{ Lil } & 39 & ArgA & & & & & & & & & & & ns & ns & " \\
\hline & 35 & ArgB & & & & & & & & & & & ns & ns & $\mathrm{ns}$ \\
\hline & 35 & Targ & & & & & & & & & & & $\mathrm{ns}$ & ns & ns \\
\hline & 35 & $\mathrm{~V} \%$ & & & & & & & & & & & ns & ns & ns \\
\hline & 35 & $\mathrm{~m}$ & & & & & & & & & & & ns & ns & ns \\
\hline \multirow[t]{5}{*}{$\mathrm{Li} 3$} & 4 & $\operatorname{ArgA}$ & & & & & & & & & & ns & & ns & ns \\
\hline & 4 & ArgB & & & & & & & & & & $\mathrm{ns}$ & & ns & $n s$ \\
\hline & 4 & Targ & & & & & & & & & & $\mathrm{ns}$ & & $\mathrm{ns}$ & ns \\
\hline & 4 & $\mathrm{~V} \%$ & & & & & & & & & & ns & & ns & $\mathrm{ns}$ \\
\hline & 4 & $\mathrm{~m}$ & & & & & & & & & & ns & & ns & ns \\
\hline
\end{tabular}


Tabela 14- Continuação.

\begin{tabular}{|c|c|c|c|c|c|c|c|c|c|c|c|c|c|c|c|}
\hline Classe & Obs & & PV1 & PV2 & PV3 & PV4 & PV5 & PV5pp & PV6 & PV7 & PV7pp & Li1 & $\mathrm{Li} 3$ & Li4 & $\mathrm{Cbl}$ \\
\hline \multirow{5}{*}{$\mathrm{Li4}$} & 9 & $\operatorname{ArgA}$ & & & & & & & & & & $\mathrm{ns}$ & ns & & ns \\
\hline & 9 & ArgB & & & & & & & & & & ns & ns & & ns \\
\hline & 9 & Targ & & & & & & & & & & ns & ns & & ns \\
\hline & 9 & $\mathrm{~V} \%$ & & & & & & & & & & ns & ns & & ns \\
\hline & 9 & $\mathrm{~m}$ & & & & & & & & & & ns & ns & & ns \\
\hline \multirow[t]{5}{*}{$\mathrm{Cb} 1$} & 8 & $\mathrm{ArgA}$ & & & & & & ns & & ns & & $"$ & ns & nis & \\
\hline & 8 & $\mathrm{ArgB}$ & & & & & & ns & & ns & & ns & ns & ns & \\
\hline & 8 & Targ & & & & & & ns & & “ & & ns & ns & ns & \\
\hline & 8 & $\mathrm{~V} \%$ & & & & & & $\mathrm{~ns}$ & & ns & & ns & ns & ns & \\
\hline & 8 & $\mathrm{~m}$ & & & & & & ns & & ns & & ns & ns & ns & \\
\hline
\end{tabular}

ns - Médias não significantes.

" - Médias com significância ao nivel de $10 \%$

* - Médias com significância ao nivel de $5 \%$.

* - Médias com significância ao nivel de $1 \%$.

As unidades PV2 vs. PV4 não apresentam diferenças significativas para os atributos de solos, apesar de apresentarem diferenças na saturação por bases e saturação por alumínio. Esta falta de diferença significativa talvez possa ser explicado por ser a unidade de mapeamento PV2 de baixa precisão, isto é, apresentam alto CV\% para seus atributos (Tabela 9). Porém, o comportamento das duas unidades de mapeamento é igual, apesar de PV4 apresentar menor variabilidade de seus atributos (é a unidade de menor variabilidade no mapa detalhado-1991, como já citado anteriormente).

Para os solos pouco profundos que apresentam horizonte diagnóstico (PV5pp, PV7pp e Cb1), as unidades de mapeamento PV5 pouco profundo vs. PV7 pouco profundo, apresentam diferenças significativas, a 5\%, para o atributo atividade da argila, porém, ambas são de atividade baixa e deveriam apresentar diferenças em termos de saturação por bases ou alumínio; essas duas unidades apresentam CV\% elevados para saturação por alumínio. A unidade Cb1 (Cambissolos) apresenta diferença significativa apenas com PV7pp, também, para atividade de argila. Neste caso Cb1 apresenta atividade de argila alta e baixa e PV7pp atividade baixa.

Comparando os solos pouco desenvolvidos, incluindo os Cambissolos (Cb1), observa-se que só existe diferença significativa entre as unidades Lil vs. Cbl, mesmo assim a $10 \%$, para textura no horizonte $\mathrm{A}$ (conteúdo de argila no horizonte $\mathrm{A}$ ); Li1 apresenta textura média e $\mathrm{Cbl}$ textura argilosa no horizonte $\mathrm{A}$. Nas demais unidades não ocorrem diferenças significativas. 
As unidades de mapeamento com horizonte B textural, no geral e com poucas exceções, apresentam diferenças significativas entre elas para os atributos utilizados como diferenciadores para fins de descrição das unidades de mapeamento. Enquanto as unidades pouco desenvolvidas apresentam poucas diferenças estatísticas.

\section{c) Mapa semidetalhado de solos}

Os resultados dos testes $t$ entre as médias de alguns atributos das unidades de mapeamento do mapa semidetalhado de solos são apresentados na Tabela 15.

Tabela 15- Teste $t$ entre os parâmetros teor de argila no horizonte $\mathrm{A}$ (Arg A), teor de argila no horizonte B (subsuperficial) (ArgB), atividade da argila no B (Targ), saturação de bases no $\mathrm{B}(\mathrm{V} \%)$ e saturação de alumínio no $\mathrm{B}(\mathrm{m})$ entre classes de solos do mapa Semi-detalhado de solos. com mais de 3 observações por unidade de mapeamento.

\begin{tabular}{|c|c|c|c|c|c|c|c|c|c|}
\hline Classe & Obs & & PV6 & PV7 & PV9 & PV7 + Li5 & TEp & $\mathrm{Li3}$ & $\mathrm{Li1}+\mathrm{Li2}+\mathrm{PV} 11$ \\
\hline \multirow[t]{5}{*}{ PV6 } & 5 & $\operatorname{ArgA}$ & & ns & $\mathrm{ns}$ & ns & $\mathrm{ns}$ & & \\
\hline & 5 & ArgB & & $" 6$ & ns & ns & ns & & \\
\hline & 5 & Targ & & ns & $*$ & $*$ & ns & & \\
\hline & 5 & $\mathrm{~V} \%$ & & ns & ns & ns & $* *$ & & \\
\hline & 5 & $\mathrm{~m}$ & & $"$ & ns & $\mathrm{ns}$ & $*$ & & \\
\hline \multirow[t]{5}{*}{ PV7 } & 8 & $\operatorname{ArgA}$ & ns & & $*$ & ** & ns & & \\
\hline & 8 & $\mathrm{ArgB}$ & 4 & & *** & $* *$ & ns & & \\
\hline & 8 & Targ & ns & & ns & ns & $*$ & & \\
\hline & 8 & $\mathrm{~V} \%$ & ns & & $*$ & $*$ & ns & & \\
\hline & 8 & $m$ & 4 & & $\neq *$ & $* *$ & ns & & \\
\hline \multirow{5}{*}{ PV9 } & 115 & $\operatorname{Arg} A$ & $\mathrm{~ns}$ & 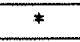 & & $* *$ & 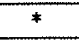 & & \\
\hline & 106 & ArgB & $\mathrm{ns}$ & ** & & $*$ & $* *$ & & \\
\hline & 106 & Targ & $*$ & ns & & ns & ** & & \\
\hline & 106 & $\mathrm{~V} \%$ & ns & $*$ & & ns & $* *$ & & \\
\hline & 106 & $m$ & ns & ** & & ns & ** & & \\
\hline \multirow{5}{*}{$\begin{array}{c}\mathrm{PV} 7+ \\
\mathrm{Li} 5\end{array}$} & 52 & $\operatorname{ArgA}$ & ns & $* *$ & $\# *$ & & ** & & \\
\hline & 52 & $\mathrm{ArgB}$ & ns & *** & $*$ & & ** & & \\
\hline & 52 & Targ & * & ns & ns & & ** & & \\
\hline & 52 & $\mathrm{~V} \%$ & ns & $*$ & $\mathrm{~ns}$ & & $* *$ & & \\
\hline & 52 & $\mathrm{~m}$ & ns & $* *$ & ns & & $\$ *$ & & \\
\hline \multirow[t]{5}{*}{ TEp } & 12 & $\operatorname{ArgA}$ & ns & ns & $*$ & ** & & ns & ** \\
\hline & 12 & ArgB & ns & $\mathrm{ns}$ & $* *$ & $* *$ & & $\mathrm{~ns}$ & ** \\
\hline & 12 & Targ & ns & $*$ & ** & $* *$ & & ** & ns \\
\hline & 12 & $\mathrm{~V} \%$ & $* *$ & ns & ** & $* *$ & & $* *$ & $\mathrm{~ns}$ \\
\hline & 12 & $\mathbf{m}$ & $*$ & ns & $* *$ & ** & & $* *$ & ns \\
\hline \multirow[t]{5}{*}{$\mathrm{Li3}$} & 49 & $\operatorname{ArgA}$ & & & & & ns & & ** \\
\hline & 46 & ArgB & & & & & ns & & $*$ \\
\hline & 46 & Targ & & & & & $* *$ & & $\mathrm{~ns}$ \\
\hline & 46 & $V \%$ & & & & & $* *$ & & $\mathrm{~ns}$ \\
\hline & 46 & $\mathrm{~m}$ & & & & & $* *$ & & $\mathrm{~ns}$ \\
\hline \multirow{5}{*}{$\begin{array}{l}\mathrm{Li1}+ \\
\mathrm{Li2}+ \\
\mathrm{PV} 11\end{array}$} & 3 & $\operatorname{ArgA}$ & & & & & ** & ** & \\
\hline & 3 & ArgB & & & & & ** & $*$ & \\
\hline & 3 & Targ & & & & & ns & ns & \\
\hline & 3 & $\mathrm{~V} \%$ & & & & & $\mathrm{~ns}$ & ns & \\
\hline & 3 & $\mathrm{~m}$ & & & & & ns & ns & \\
\hline
\end{tabular}

ns - Médias não significantes.

"- Médias com significância ao nivel de 10\%

* - Médias com significância ao nivel de 5\%.

** - Médias com significancia ao nivel de 1\% 
É importante ressaltar que ocorrem diferenças significativas entre todas as unidades, comparadas no mapa semidetalhado de solos para pelo menos um atributo de solos utilizado para diferenciação, apesar de serem unidades de mapeamento que são associações e complexos de várias unidades de classificação.

\subsection{Concordância dos mapas de solos}

A análise das concordâncias dos mapas de solos foi feita através de matrizes de sobreposição dos mapas, fazendo-se três sobreposições entre os mapas da área de estudo: Mapa detalhado de solos-2000 x Mapa semidetalhado de solos; Mapa detalhado de solos-1991 x Mapa semidetalhado de solos; e Mapa detalhado de solos-2000 x Mapa detalhado de solos-1991.

\subsubsection{Concordâncias entre o mapa detalhado-2000 e mapa semidetalhado}

A sobreposição do Mapa detalhado-2000 X Mapa semidetalhado, gerou uma matriz de concordância entre as unidades dos dois mapas. A matriz resultante, que é apresentada na forma de mapa de concordância na Figura 12 e os resultados apresentados na Figura 13, mostra que existe uma concordância muito baixa entre os dois níveis de levantamento. Considerando que as classes de concordância Equivalentes com Associações e Correspondentes indiquem Boa concordância, apenas $38 \%$ das áreas da microbacia apresentam a mesma classificação dos solos, enquanto $37 \%$ não possuem concordância alguma de classes de solos (Não Correspondentes) e 25\% apresentam apenas a mesma classe de solos (Semelhantes) e não apresentam equivalência em nenhum outro atributo utilizado para a classificação do solo, como, atividade da argila, saturação por bases e/ou alumínio, textura, profundidade. A ausência da classe Equivalentes foi devido a predominância no mapa semidetalhado de unidades de mapeamento composta. 


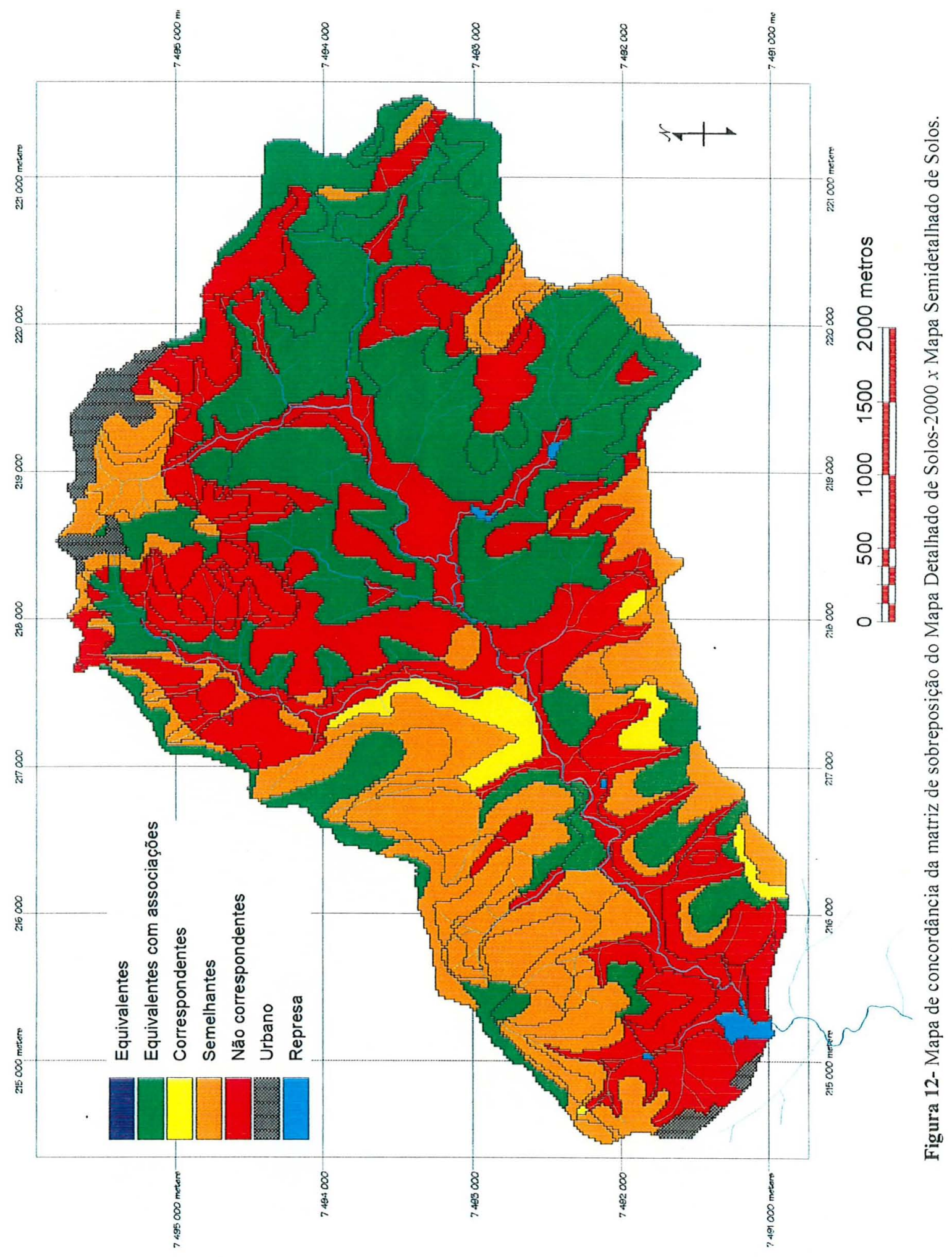




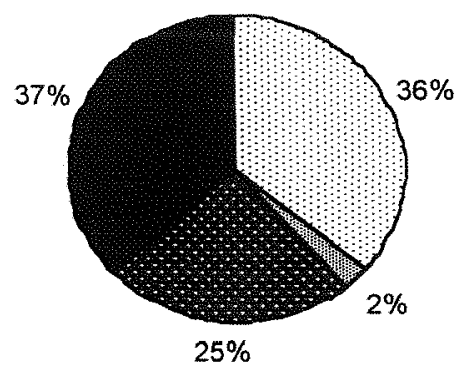

Figura 13- Gráfico mostrando a distribuição das classes de concordância da matriz de sobreposição do mapa detalhado-2000 $X$ mapa semidetalhado.

A concordância muito baixa entre o mapa detalhado-2000 e o mapa semidetalhado pode ser explicada por alguns fatores:

1) Os solos na microbacia são complexos, apresentando alta variabilidade espacial e em profundidade, devido aos diferentes materiais de origem e ao relevo acidentado, como já discutido anteriormente.

2) A base cartográfica original (IAC) do mapa semidetalhado (escala 1:100.000) não é digital, o que pode provocar diferenças e deslocamentos nos ajustes das unidades do mapa. Pequenos deslocamentos, tais como $1 \mathrm{~mm}$ no mapa eqüivale a $100 \mathrm{~m}$ no campo.

3) A diferença entre as escalas de trabalho é muito grande. O mapa detalhado é 100 vezes maior que o semidetalhado. O que aumenta a possibilidade de maior precisão nas unidades de mapeamento, devido ao número maior de amostras por área (aumentando a pureza e precisão) e melhor checagem dos limites das unidades de mapeamento (Marsman \& Gruijter, 1986; Embrapa, 1995).

4) Execução dos levantamentos por equipes de pedologia diferentes (Diferentes pedólogos executores), pode alterar o resultado do mapeamento, como salientado em Bie \& Beckett (1973). 
Coincidência espacial de 19,5\% (igual a classe equivalentes neste trabalho), entre as unidades de mapeamento idênticas entre um levantamento de reconhecimento na escala 1:100.000 e um levantamento detalhado na escala 1:10.000, foi obtida por Ranieri (1996). Quando foram consideradas unidades de mapeamento com alguma correspondência entre as duas escalas, a porcentagem de sobreposição entre os dois mapas foi muito significativa (68\%). Ela concluiu que a diferença encontrada entre os dois mapas estava basicamente na melhor separação entre as unidades ou na melhor definição entre os limites espaciais de cada unidade.

\subsubsection{Concordâncias entre o mapa detalhado-1991 e o mapa semidetalhado}

A sobreposição do mapa detalhado de solos-1991 e mapa semidetalhado de solos, apresentado na Figura 14 e os resultados na Figura 15, também indicam uma concordância muito baixa entre os dois levantamentos. As três primeiras classes (Equivalentes, Equivalentes com Associações e Correspondentes) de melhor concordância são responsáveis por apenas $35 \%$, enquanto que a classe Não Correspondentes, indicativa de nenhuma concordância entre as unidades dos mapas, ocupa $42 \%$ da área total da microbacia. Se for considerado que a classe Semelhantes também é de baixa concordância, teríamos $2 / 3$ da área com baixa ou nenhuma concordância. Estes resultados também podem ser explicados como os apresentados anteriormente.

Os resultados apresentados mostram que a concordância do mapa detalhado-2000 $X$ mapa semidetalhado e mapa detalhado-1991 $X$ mapa semidetalhado, indicam que o modelo testado não é um modelo simples, isto é, o mapa semidetalhado não é uma simplificação dos mapas detalhados. O mapa detalhado pode ser considerado, de acordo com os resultados, um outro mapa de solos. 


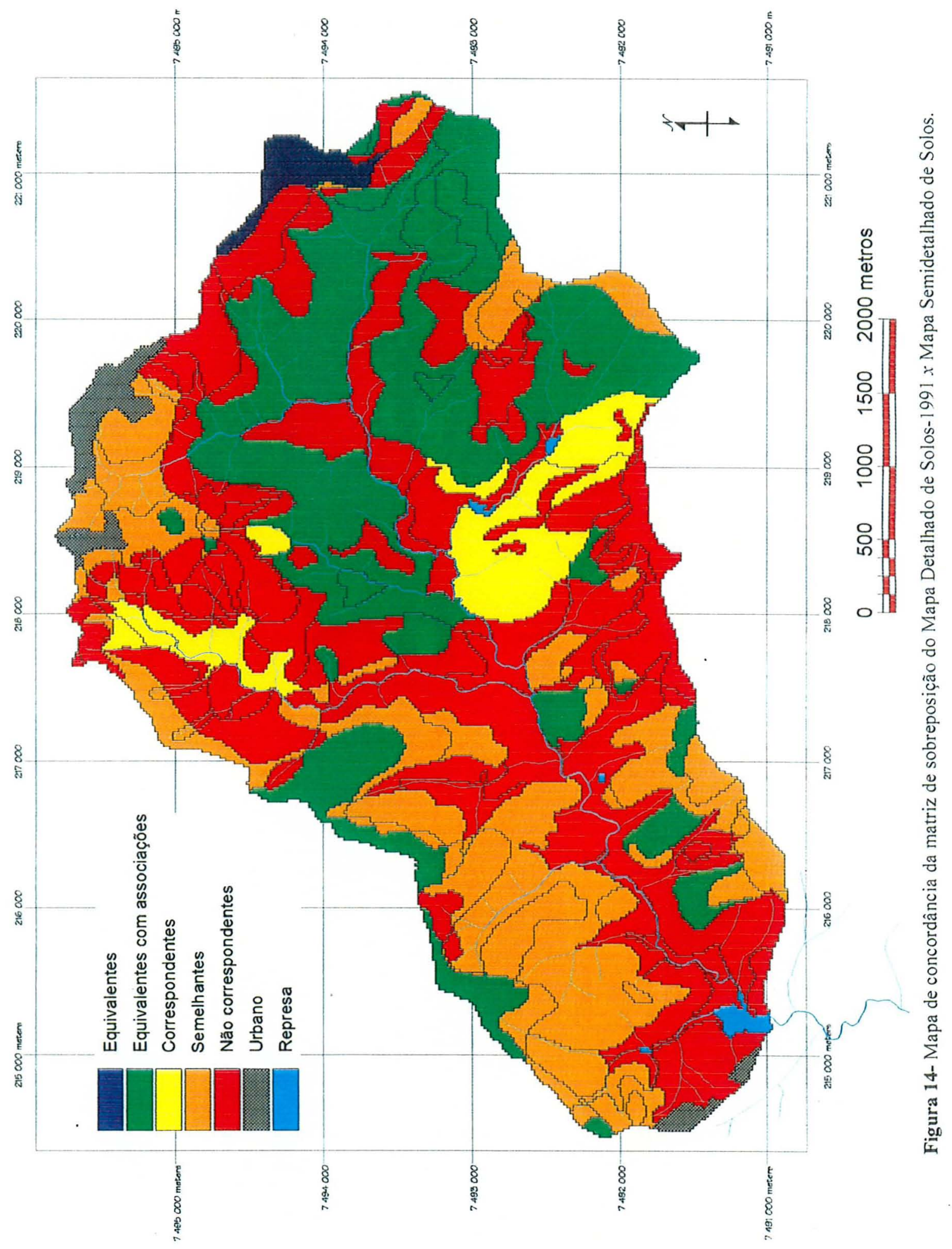




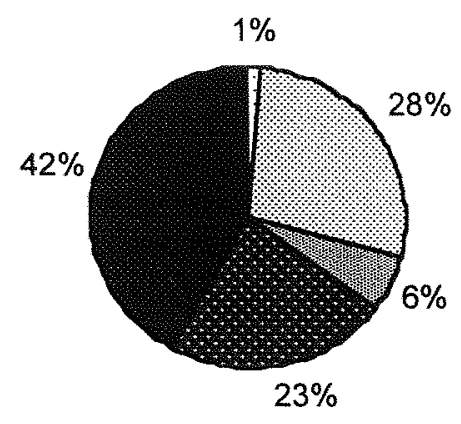

Equivalentes

Equivalentes com Associações

Correspondentes

Semelhantes

Não Correspondentes

Figura 15- Gráfico mostrando a distribuição das classes de concordância da matriz de sobreposição do mapa detalhado-1991 $X$ mapa semidetalhado.

\subsubsection{Concordâncias entre o mapa detalhado-2000 e mapa detalhado-1991}

A sobreposição entre o mapa detalhado-2000 e mapa detalhado-1991 foi feita para avaliar as diferenças existentes nos mapeamentos executados em épocas diferentes e equipes diferentes. O resultado é apresentado no mapa de concordância (Figura 16). Observa-se que a soma das três primeiras classes de concordância indica uma boa concordância em pouco mais que metade da área total (52\%), enquanto que a classe $N a ̃ o$ correspondentes ocorre em apenas $24 \%$ da área e quando somado à classe Semelhantes, que é uma classe de baixa concordância, passam a ocupar quase metade da área de estudo. Apesar dos resultados das concordâncias serem um pouco melhores que os obtidos com as duas sobreposições envolvendo o mapa semidetalhado, a concordância ainda é baixa, considerando que ambos foram feitos na mesma escala, porém, com critérios diferentes (Figura 17).

Estes resultados também reforçam a hipótese de complexidade e variabilidade dos solos da microbacia. Como já discutido anteriormente, Bie \& Beckett (1973) comparando mapas, na mesma escala, produzidos por quatro equipes diferentes e independentes, também observaram que os mapas eram consideravelmente diferentes. 


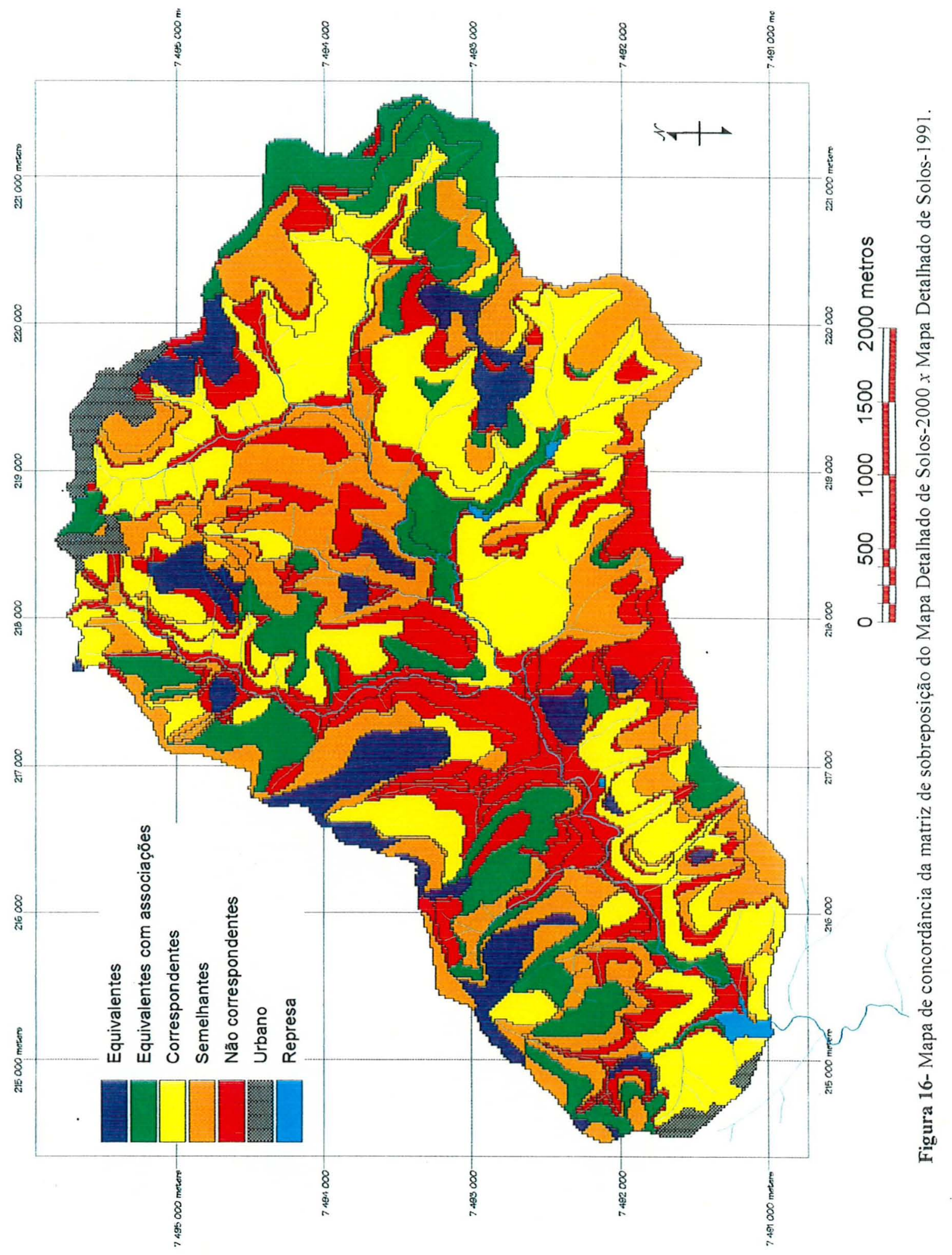



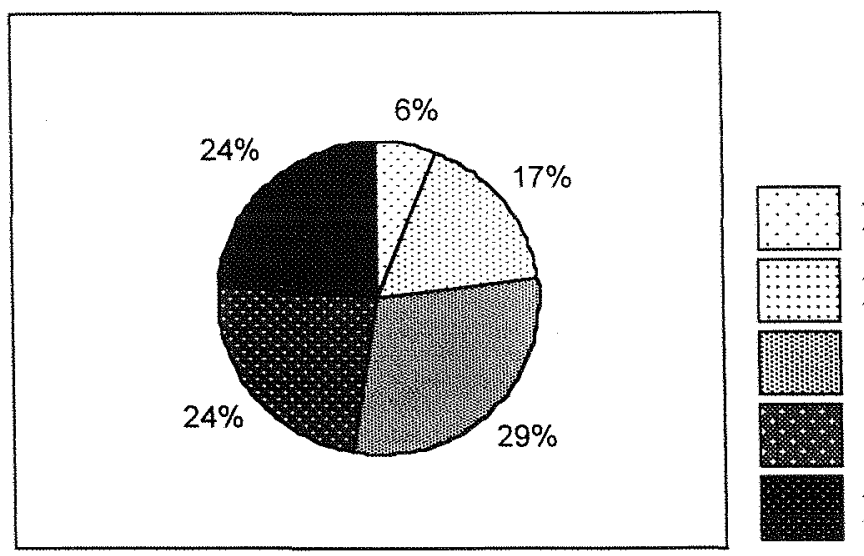

Equivalentes

Equivalentes com Associações

Correspondentes

Semelhantes

Não Correspondentes

Figura 17- Gráfico mostrando a distribuição das classes de concordância da matriz de sobreposição do mapa detalhado-2000 X mapa detalhado-1991.

Alta influência do avaliador no resultado da classificação das terras em capacidade de uso foi obtida por Focht (1998), usando como área teste a mesma microbacia do Córrego do Ceveiro. O parâmetro $\mathrm{k}$ \{́ndice Kappa - utilizado para avaliar a concordância, varia de menos que 0,1 (péssima concordância) a 1 (concordância total)\} variou entre 0,23 e 0,52 , e com coeficiente de variação entre 39 e $260 \%$. Estes números indicaram que a concordância espacial entre as classificações feitas pelos avaliadores foi muito baixa e que os resultados dependeram da qualificação profissional do avaliador.

Além de equipes diferentes e complexidade dos solos como responsáveis pela baixa concordância, outra explicação pode ser dada - a diferença nos materiais cartográficos e o uso de melhores ferramentas cartográficas no levantamento detalhado de 2000. Um primeiro indício dessas diferenças pode ser obtido visualmente ao observar o mapa detalhado-1991 (Figura 7) e o mapa detalhado-2000 (Figura 11); nota-se, no mapa detalhado-1991, que ocorre um deslocamento em algumas unidades de mapeamento. Esses deslocamentos podem ter ocorrido na confecção do mapa original, que não contou com recursos de GPS nem de Sistema de Informações Geográficas (SIG). 
A menor quantidade de amostras analisadas no mapa detalhado-1991 em relação ao mapa detalhado-2000, pode ter influenciado na menor acurácia (como discutido no item 4.4.3), reduzindo a concordância entre os dois mapas.

A elevada variância existente nas unidades de mapeamento dos dois mapas traz como consequência a possibilidade de traçar limites entre as unidades de mapeamento com pouca precisão e áreas com baixa concordância entre os mapas.

\subsubsection{Relação entre variabilidade das unidades de mapeamento e concordância dos mapas}

A relação entre variabilidade das unidades de mapeamento e concordância dos mapas foi obtida separando-se as unidades de mapeamento, de cada mapa de solos, que apresentavam no seu conjunto menores e maiores variabilidades dos atributos de solos e observando-se os resultados da concordância após a sobreposição dos mapas.

Foram utilizadas as seguintes unidades de mapeamento:

- Mapa detalhado de solos-2000 (D2000) - menor variabilidade = ACt1, PVAel2, PVe e NVe; maior variabilidade $=$ RUbe.

- Mapa detalhado de solos-1991 (D1991) - menor variabilidade = PV4; maior variabilidade $=$ PV1 e PV3.

- Mapa semidetalhado de solos (Semi) - menor variabilidade = PV6; maior variabilidade $=$ PV9 e TEp.

A hipótese a ser testada aqui seria que unidades de mapeamento de menor variabilidade apresentariam alta concordância após sobreposição dos mapas, e que unidades de mapeamento de maior variabilidade apresentariam baixa concordância.

$\mathrm{Na}$ Tabela 16 observa-se que considerando as três primeiras classes de concordância (Equivalentes, Equivalentes com associações e Correspondentes) como de alta concordância, e as classes Semelhantes e Não correspondentes como de baixa ou nenhuma concordância, somente para a sobreposição do mapa detalhado-2000 x mapa 
detalhado-1991, 70\% das áreas, com unidades de mapeamento com menor variabilidade, apresentavam alta concordância. Para as outras sobreposições, obtivemos $39 \%$ para o mapa detalhado-2000 $x$ mapa semidetalhado e $0 \%$ para o mapa detalhado-1991 $x$ mapa semidetalhado.

Tabela 16- Relação de concordância entre as unidades de mapeamento de menor variabilidade com a sobreposição dos mapas.

\begin{tabular}{|c|c|c|c|}
\hline Concordância & D2000 $\times$ Semi & D1991 x Semi & D2000 x D1991 \\
\hline & $(\%)$ & $(\%)$ & $(\%)$ \\
\hline Equivalentes & 0 & 0 & 16.9 \\
\hline Equiv. associações & 34.4 & 0 & 25.0 \\
\hline Correspondentes & 4.9 & 0.1 & 27.9 \\
\hline Semelhantes & 35.9 & 91.2 & 16.7 \\
\hline Não correspondentes & 24.9 & 8.7 & 13.5 \\
\hline Total & 100.0 & 100.0 & 100.0 \\
\hline
\end{tabular}

Considerando as unidades de mapeamento com maior variabilidade (Tabela 17) obtivemos que $82 \%$ da área de sobreposição do mapa detalhado-2000 $x$ mapa semidetalhado, $89 \%$ da área de sobreposição do mapa detalhado-1991 $x$ mapa semidetalhado e $60 \%$ da área de sobreposição do mapa detalhado-2000 $x$ mapa detalhado-1991, apresentam baixa concordância.

Tabela 17- Relação de concordância entre as unidades de mapeamento de maior variabilidade com a sobreposição dos mapas.

\begin{tabular}{|c|c|c|c|}
\hline Concordância & D2000 $\times$ Semi & D1991 x Semi & D2000 x D1991 \\
\hline & $(\%)$ & $(\%)$ & $(\%)$ \\
\hline Equivalentes & 0 & 0 & 25.0 \\
\hline Equiv. associações & 13.3 & 0 & 9.1 \\
\hline Correspondentes & 5.0 & 10.8 & 6.4 \\
\hline Semelhantes & 31.8 & 39.3 & 48.6 \\
\hline Não correspondentes & 49.8 & 49.9 & 10.9 \\
\hline Total & 100.0 & 100.0 & 100.0 \\
\hline
\end{tabular}


Esses resultados (qualitativos) são indicativos, porém não conclusivos, de que existe uma relação, para esses mapas, das unidades de maior variabilidade com baixa concordância na sobreposição dos mapas. Para as unidades de menor variabilidade não se pode indicar que existe uma relação de alta concordância na sobreposição dos mapas, isto é, unidades de mapeamento de menor variância, não necessariamente, apresentam alta concordância entre os mapas.

\subsection{Pureza dos mapas de solos}

A pureza é usada comumente para quantificar a acurácia de mapas de solos (Becket \& Webster, 1971; Bie \& Beckett, 1971; Bie \& Beckett, 1973; Marsman \& Gruijter, 1986 e Wilding et al., 1965). É uma medida objetiva com significação limitada para usuários de mapa. A pureza só indica até que ponto o conteúdo das áreas delineadas corresponde às especificações no sistema de classificação usado. Porcentagens de pureza indicam a acurácia, mas não necessariamente são relacionadas a aplicações particulares de mapas de solo. Também, pureza não diferencia entre critérios de classificação importantes e menos importantes.

\subsubsection{Representatividade da amostragem externa}

Para determinação da acurácia dos mapeamentos de solos, uma nova amostragem foi realizada com sorteio, aleatório por computador, de 29 pontos. Esses pontos amostrados foram chamados de "amostras externas". Os solos, nos pontos amostrados, foram classificados e o resultado é apresentado na Tabela 18. A checagem dos mapas foi feita utilizando-se as amostras externas georeferenciadas que foram plotadas nos mapas estudados. Então se determinou qual classe ocorre em cada perfil das amostras externas utilizando-se a classificação do mapeador. Quando as classes preditas, mapeadas, e as observadas nas amostras externas são exatamente as mesmas a predição é correta Pureza total; quando as amostras externas preenchem parcialmente os critérios de classificação da unidade mapeada, a predição é parcialmente correta - Pureza parcial/Correspondente ou Pureza parcial/Semelhantes; ou quando as amostras externas 
não são da mesma classe de solos da unidade de mapeamento a predição é errada - Não correspondentes (Tabela 19). (Ver item 3.5.3 do Material e Métodos).

Inicialmente, observa-se na Tabela 18 que nos solos amostrados dominam os NEOSSOLOS LITÓLICOS (Solos Litólicos) e os solos com horizonte B textural ALISSOLOS, ARGISSOLOS e LUVISSOLOS (Podzólicos Vermelho Amarelos), o que corresponde à dominância desses solos na Microbacia Hidrográfica do Córrego do Ceveiro.

Tabela 18- Classificação dos solos das amostras externas para Pureza dos mapas.

\section{$\mathbf{N}^{0}$ Pt. Classificação do Solo}

02 ALISSOLO CRÔMICO Argilúvico abrúptico epidistrófico (Podzólico Vermelho-Amarelo Ta Álico epidistrófico Abrupto) A moderado textura arenosa/média

04 LUVISSOLO CRÔMICO Pálico arênico abrúptico (Podzólico Vermelho-Amarelo Ta Eutrófico Abrupto fase arênico) A moderado textura arenosa/média

15 NEOSSOLO LITÓLICO Eutrófico típico Ta (Solos Litólicos Ta Eutrófico) A moderado textura argilosa substrato siltíto da formação Corumbataí.

17 NEOSSOLO LITÓLICO Distrófico típico Tb (Solos Litólicos Tb Distrófico) A moderado textura média substrato arenito da formação Pirambóia.

26 ARGISSOLO VERMELHO-AMARELO Eutrófico léptico (Podzólico Vermelho-Amarelo Abrupto Tb Eutrófico fase pouco profundo) A moderado textura arenosa/média

27 LUVISSOLO CRÔMICO Órtico léptico abrúptico (Podzólico Vermelho-Amarelo Abrupto Ta Eutrófico fase pouco profundo) A moderado textura arenosa/média

28 ARGISSOLO VERMELHO-AMARELO Alumínico abrúptico (Podzólico Vermelho-Amarelo Abrupto $\mathrm{Tb}$ Álico) A moderado textura arenosa/média

30 NEOSSOLO LITÓLICO Eutrófico típico Tb (Solos Litólicos Tb Eutrófico) A moderado textura argilosa substrato folhelho da formação Corumbataí.

32 ALISSOLO CRÔMICO Argilúvico abrúptico (Podzólico Vermelho-Amarelo Abrupto Tb Álico) textura arenosa/média fase erodida

33 ARGISSOLO VERMELHO-AMARELO Distrófico arênico abrúptico álico epieutróficos (Podzólico Vermelho-Amarelo Tb Álico epieutrófico Abrupto fase arênico) A moderado textura arenosa/média

39 NEOSSOLO LITÓLICO Eutrófico típico Tb (Solos Litólicos Tb Eutrófico) A moderado textura média substrato folhelho da formação Corumbataí.

45 NEOSSOLO LITÓLICO Eutrófico típico Tb (Solos Litólicos Tb Eutrófico) A moderado textura argilosa substrato folhelho da formação Corumbataí.

46 NEOSSOLO LITÓLICO Eutrófico típico Tb (Solos Litólicos Tb Eutrófico) A moderado textura argilosa substrato siltítos da formação Corumbataí.

47 NEOSSOLO LITÓLICO Eutrófico típico Ta (Solos Litólicos Tb Eutrófico) A fraco textura média substrato folhelho da formação Corumbatai.

51 GLEISSOLO HÁPLICO Tb Eutrófico típico (Glei Pouco Húmico Tb Eutrófico) A moderado textura média/argilosa 
Tabela 18- Continuação.

\begin{tabular}{|c|c|}
\hline $\mathbf{N}^{0} \mathbf{P t}$ & Classificação do Solo \\
\hline 52 & $\begin{array}{l}\text { CAMBISSOLO HÁPLICO Tb Eutrófico léptico (Cambissolo Tb Eutrófico) A moderado textura } \\
\text { argilosa substrato folhelho da formação Corumbataí. }\end{array}$ \\
\hline 53 & $\begin{array}{l}\text { NEOSSOLO LITÓLICO Eutrófico típico Tb (Solos Litólicos Tb Eutrófico) A moderado textura } \\
\text { argilosa substrato folhelho da formação Corumbataí. }\end{array}$ \\
\hline 54 & $\begin{array}{l}\text { ARGISSOLO VERMELHO-AMARELO Eutrófico abrúptico (Podzólico Vermelho-Amarelo } \\
\text { Abrupto Tb Eutrófico) A moderado textura média/argilosa }\end{array}$ \\
\hline 65 & $\begin{array}{l}\text { ARGISSOLO VERMELHO-AMARELO Eutrófico abrúptico (Podzólico Vermelho-Amarelo Ta } \\
\text { Eutrófico Abrupto) A moderado textura arenosa/média fase erodido }\end{array}$ \\
\hline 67 & $\begin{array}{l}\text { NEOSSOLO LITÓLICO Eutrófico típico Tb (Solos Litólicos Tb Eutrófico) A moderado textura } \\
\text { argilosa substrato folhelho da formação Corumbataí. }\end{array}$ \\
\hline 78 & $\begin{array}{l}\text { NEOSSOLO LITÓLICO Eutrófico típico Ta (Solos Litólicos Ta Eutrófico) A moderado textura } \\
\text { argilosa substrato folhelho da formação Corumbatai. }\end{array}$ \\
\hline 80 & $\begin{array}{l}\text { NEOSSOLO LITÓLICO Eutrófico típico Ta (Solos Litólicos Ta Eutrófico) A moderado textura } \\
\text { média substrato arenito da formação Pirambóia. }\end{array}$ \\
\hline 85 & $\begin{array}{l}\text { ALISSOLO CRÔMICO Argilúvico abrúptico (Podzólico Vermelho-Amarelo Ta Eutrófico) A } \\
\text { moderado textura arenosa/média fase erodida }\end{array}$ \\
\hline 86 & $\begin{array}{l}\text { NEOSSOLO LITÓLICO Eutrófico típico Tb (Solos Litólicos Tb Eutrófico) A moderado textura } \\
\text { média substrato folhelho da formação Corumbatai. }\end{array}$ \\
\hline 87 & $\begin{array}{l}\text { NEOSSOLO LITÓLICO Eutrófico típico Ta (Solos Litólicos Tb Eutrófico) A moderado textura } \\
\text { média substrato folhelho da formação Corumbataí. }\end{array}$ \\
\hline 88 & $\begin{array}{l}\text { LUVISSOLO CRÔMICO Órtico léptico abrúptico epidistrófico (Podzólico Vermelho-Amarelo } \\
\text { Abrupto Ta Eutrófico epidistrófico fase pouco profundo) A moderado textura média/argilosa }\end{array}$ \\
\hline 92 & $\begin{array}{l}\text { LUVISSOLO CRÔMICO Pálico abrúptico (Podzólico Vermelho-Amarelo Abrupto Ta Eutrófico) } \\
\text { A moderado textura média/argilosa }\end{array}$ \\
\hline 95 & $\begin{array}{l}\text { NEOSSOLO LITÓLICO Eutrófico típico Tb (Solos Litólicos Tb Eutrófico) A moderado textura } \\
\text { média substrato folhelho da formação Corumbataí fase cascalhento. }\end{array}$ \\
\hline 96 & $\begin{array}{l}\text { LUVISSOLO CRÔMICO Pálico abrúptico (Podzólico Vermelho-Amarelo Abrupto Ta Eutrófico) } \\
\text { A moderado textura média/argilosa }\end{array}$ \\
\hline
\end{tabular}

Considerando-se o mapa semidetalhado e a Tabela 4 (área do mapa semidetalhado), observa-se que foram checados $73,7 \%$ da área do mapa, nota-se que as unidades PV6 e Li6 +TE, que representam apenas 1,3\% da área, não possuem amostras externas. A unidade $L i 3$, que ocupa $41,5 \%$ da microbacia, foi checada com $38 \%$ das amostras externas; enquanto a unidade $P V 9$, que cobre $32,2 \%$ da área, foi contemplada com $28 \%$ das amostras externas. Esses dados mostram que as amostras externas, apesar de pouca quantidade, apenas 29 pontos, são bem representativas.

Observando-se o mapa detalhado-2000 e sua distribuição de área (Tabela 6) conclui-se que as amostras externas cobrem $75 \%$ da área total da MHCC. A unidade de mapeamento de maior ocupação (RLe4), 16\% da área, também foi a mais representada 
com 21\% das amostras externas. Já no mapa detalhado-1991, de acordo com a Tabela 5, a representatividade da amostragem externa é de $80 \%$ da área, enquanto a unidade de mapeamento de maior ocorrência, a Lil com $28 \%$ da área total da microbacia, é a de maior representatividade com $28 \%$ das amostras externas.

Tabela 19- Classe de Pureza das unidades de mapeamento dos mapas estudados.

\section{Mapa Semidetalhado Mapa Detalhado-2000 Mapa Detalhado-1991}

$\begin{array}{llllll}\mathbf{N}^{0} \text { Ponto } & \text { Un. Mapa } & \text { Cl. Pureza Un. Mapa } & \text { Cl. Pureza } & \text { Un. Mapa } & \text { Cl. Pureza }\end{array}$

\begin{tabular}{|c|c|c|c|c|c|c|}
\hline 2 & PV9 & Semelhantes & $\mathrm{ACt} 2$ & Pureza total & PV2 & Pureza total \\
\hline 4 & PV7 + Li5 & Pureza total & ACtq & Correspond. & PV3 & Correspond. \\
\hline 15 & PV9 & Não Corresp & RLe1 & Correspond. & Li 1 & Correspond. \\
\hline 17 & PV9 & Não Corresp & RLe1 & Correspond. & PV2 & Não Corresp \\
\hline 26 & PV9 & Semelhantes & PVAall & Correspond. & PV2 & Semelhantes \\
\hline 27 & $\mathrm{Li} 1+\mathrm{Li} 2+\mathrm{PV} 11$ & Semelhantes & PVAe3 & Semelhantes & PV1 & Semelhantes \\
\hline 28 & PV7 + Li5 & Pureza total & $\mathrm{ACt} 3$ & Pureza total & PV3 & Semelhantes \\
\hline 30 & Li3 & Pureza total & RLe4 & Pureza total & Li 1 & Correspond. \\
\hline 32 & PV9 & Semelhantes & $\mathrm{ACt} 3$ & Pureza total & PV1 & Pureza total \\
\hline 33 & PV7 + Li5 & Pureza total & ACtq & Pureza total & PV3 & Pureza total \\
\hline 39 & TEp & Não Corresp & RLe4 & Pureza total & PV5 & Não Corresp \\
\hline 45 & PV9 & Não Corresp & $\mathrm{ACt} 2$ & Não Corresp & $\mathrm{Cb} 2$ & Não Corresp \\
\hline 46 & PV9 & Não Corresp & PVAe3 & Não Corresp & PV7 & Não Corresp \\
\hline 47 & $\mathrm{Li} 3$ & Pureza total & RLe4 & Pureza total & $\mathrm{Li} 1$ & Pureza total \\
\hline 51 & $\mathrm{Li} 3$ & Não Corresp & GX3 & Pureza total & $\mathrm{Li} 1$ & Não Corresp \\
\hline 52 & $\mathrm{Li} 3$ & Não Corresp & CXvbed & Pureza total & $\mathrm{Li} 4$ & Não Corresp \\
\hline 53 & Li3 & Pureza total & CXvbed & Pureza total & $\mathrm{Li} 4$ & Correspond. \\
\hline 54 & TEp & Não Corresp & PVAel3 & Pureza total & PV3 & Semelhantes \\
\hline 65 & PV7 + Li5 & Pureza total & PVAeq & Correspond. & PV2 & Correspond. \\
\hline 67 & $\mathrm{Li} 3$ & Pureza total & RLe4 & Pureza total & PV7pp & Não Corresp \\
\hline 78 & $\mathrm{Li1}+\mathrm{Li2}+\mathrm{PV} 11$ & Semelhantes & CXvbed & Pureza total & Li 1 & Correspond. \\
\hline 80 & PV9 & Não Corresp & RLe4 & Correspond. & Li 1 & Correspond. \\
\hline 85 & $\mathrm{Li3}$ & Não Corresp & TCol2 & Semelhantes & Li 1 & Não Corresp \\
\hline 86 & $\mathrm{Li} 3$ & Pureza total & RLe4 & Pureza total & Li 1 & Correspond. \\
\hline 87 & Li3 & Pureza total & PVAel & Não Corresp & PV1 & Não Corresp \\
\hline 88 & $\mathrm{Li} 3$ & Não Corresp & $\mathrm{TCol} 2$ & Pureza total & PV5pp & Pureza total \\
\hline 92 & PV7 & Semelhantes & PVAe3 & Correspond. & $\mathrm{Cbl}$ & Não Corresp \\
\hline 95 & $\mathrm{Li} 3$ & Correspond. & RLe2 & Correspond. & PV6 & Não Corresp \\
\hline 96 & PV7 & Semelhantes & PVAe3 & Correspond. & $\mathrm{Cbl}$ & Não Corresp \\
\hline
\end{tabular}

Obs: Un. Mapa - Unidade de mapeamento; Cl. Pureza - Classe de Pureza; Correspond. - Pureza parcial/Correspondente; Semelhantes - Pureza parcial/Semelhantes; Não corresp - Não correspondentes. 


\subsubsection{Pureza do mapa semidetalhado de solos}

Ao analisar as amostras externas, o mapa semidetalhado (Tabela 19) e a Figura 18, nota-se a dominância das duas classes de Pureza opostas. A classe Pureza total representa $34 \%$ da amostragem externa (equivalente a $34 \%$ da área) no mapa; enquanto que no outro extremo, a classe Não Correspondentes ocorre em $38 \%$ da amostragem externa (44\% da área) no mapa. Considerando-se, também, a classe Pureza parcial/Semelhantes como de baixa pureza, $62 \%$ da amostragem externa (62\% da área) mostraram a baixa pureza do mapa semidetalhado.

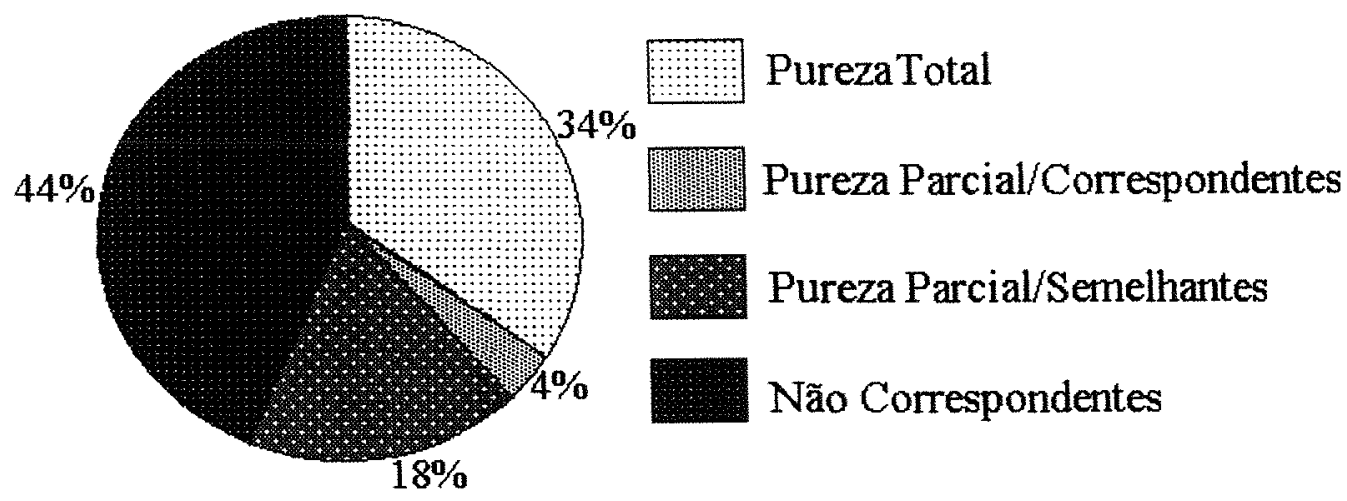

Figura 18-Gráfico mostrando as classes de pureza do mapa semidetalhado de solos.

A baixa pureza do mapa semidetalhado pode ser explicada por alguns fatores:

a) A escala de trabalho do mapa original 1:100.000 é bastante pequena para representar a realidade local da área. Sendo inadequada para planejamentos locais ou utilização para modelos que necessitem de informações pontuais.

b) Os solos da microbacia são bastante complexos, como já discutido anteriormente, e apresentam uma grande variabilidade espacial de seus atributos, tanto morfo-genéticos como físico e químicos.

Para testar a hipótese de que unidades com menor ou maior variabilidade apresentam melhor ou pior pureza, relacionou-se a precisão (variância) e a pureza (acurácia) das unidades de mapeamento (Tabela 10 e Tabela 19) do mapa semidetalhado de solos. Observa-se que as unidades de maior variabilidade do mapa semidetalhado - 
PV9 e TEp - apresentam classes de pureza - 30\% Pureza parcial/Semelhantes e 70\% Não correspondentes - considerando que essas classes são de baixa pureza, estas unidades apresentam 100\% de baixa pureza. A unidade de mapeamento PVó, que apresenta em média menor variabilidade, não possui amostragem externa. A unidade de mapeamento $\mathrm{Li3}$, que também possui alta variabilidade apresentou $55 \%$ das amostras com classe Pureza total, 9\% Pureza parcial/Correspondentes e $36 \%$ Não correspondentes, considerando as duas primeiras classes como de alta pureza, $64 \%$ das amostras externas presentes na unidade de mapeamento apresentam alta pureza.

Ocorre indicativo de que unidades com alta variabilidade apresentam baixa pureza, mas, os resultados não são conclusivos.

\subsubsection{Pureza do mapa detalhado de solos-1991}

Ao observar a coluna de classe de pureza do mapa detalhado-1991 na Tabela 19 e a Figura 19, nota-se o grande número de amostras externas que apresentam classe de pureza Não Correspondentes, totalizando $36 \%$ da área da microbacia; se juntarmos a classe Pureza Parcial/Semelhantes, considerada de baixa pureza, quase metade da área do mapa de solos (46\%) possui baixa ou nenhuma pureza, o que é muito elevado para um mapa detalhado. As amostras externas que apresentam classe Pureza Total no mapa detalhado-1991 correspondem a apenas $20 \%$ da área da microbacia.

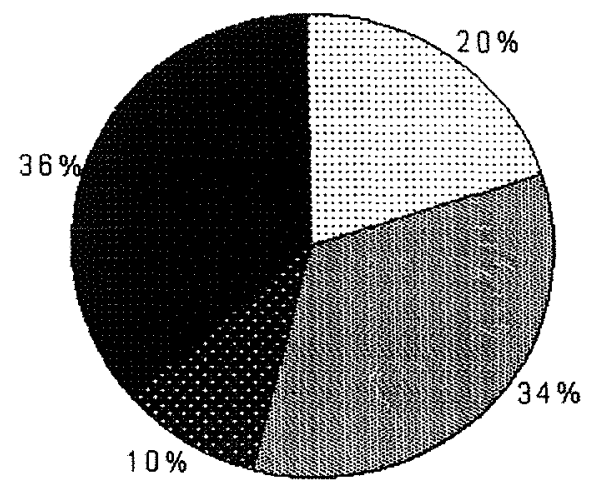

PurezaTotal

Pureza Parcial/Correspondentes

Pureza Parcial/Semelhantes

Não Correspondentes

Figura 19- Gráfico mostrando as classes de pureza do mapa detalhado de solos-1991. 
Alguns fatores poderiam explicar a baixa acurácia do mapa detalhado-1991:

1) A grande variabilidade dos solos da microbacia, quando se refere aos atributos químicos, como já descritos anteriormente, ou quando se refere às características morfogenéticas;

2) Deslocamento de algumas unidades de mapeamento no mapa detalhado1991, quando da confecção do mapa original (já citado quando da discussão dos cruzamentos dos mapas);

3) Menor quantidade de resultados analíticos do mapa detalhado-1991 quando comparado com o mapa detalhado-2000.

Para avaliar se as unidades com menor ou maior variabilidade apresentam alta ou baixa pureza, relacionou-se a precisão (variância) e a pureza (acurácia) das unidades de mapeamento (Tabela 9 e Tabela 19) do mapa detalhado de solos-1991. As unidades de maior variabilidade (avaliado através dos coeficientes de variação dos atributos de solos e índices médios) do mapa detalhado-1991 - PVI e PV3-foram checados por 7 amostras externas, sendo que $43 \%$ apresentam alta pureza ( 2 amostras na classe Pureza total e 1 Pureza parcial/Correspondentes) e $57 \%$ baixa pureza (3 amostras na classe Pureza parcial/Semelhantes e 1 Não correspondentes). A unidade de mapeamento Lil, que apresenta alta variabilidade e foi checada por 8 amostras externas, apresenta $75 \%$ das amostras com alta pureza (1 amostra da classe Pureza total e 5 Pureza parcial/Correspondentes) e $25 \%$ na classe Não correspondentes. Assim como no mapa semidetalhado estes resultados são indicativos, porém não conclusivos, que ocorre ou não uma relação entre alta variabilidade e baixa pureza ou baixa variabilidade e alta pureza. Para avaliar melhor essa questão seria necessária uma quantidade maior de amostras externas para checagem da pureza.

\subsubsection{Pureza do mapa detalhado de solos-2000}

Analisando-se a amostragem externa em relação ao mapa detalhado-2000 na Tabela 19 e o gráfico da Figura 20, pode-se notar que as amostras externas que apresentaram classe de pureza Pureza Total correspondem a 52\% das áreas do mapa de 
solos da MHCC. As amostras externas com classe Pureza parcial/Correspondentes, ainda considerado de alta pureza, representam $30 \%$ da área da microbacia. As amostras externas que apresentam classes de baixa ou nenhuma pureza, Pureza parcial/Semelhantes e Não Correspondentes, correspondem a $18 \%$ da área; enquanto que se considerarmos as amostras externas que apresentam alta pureza no mapa detalhado-2000, Pureza Total e Pureza Parcial/Correspondentes, perfazem $82 \%$ da área da microbacia. Considerando essas informações e apesar da baixa quantidade de amostras externas, podemos concluir que o mapa detalhado de solos-2000 possui uma boa acurácia, quando é utilizado o parâmetro amostragem externa para inferir essa condição.

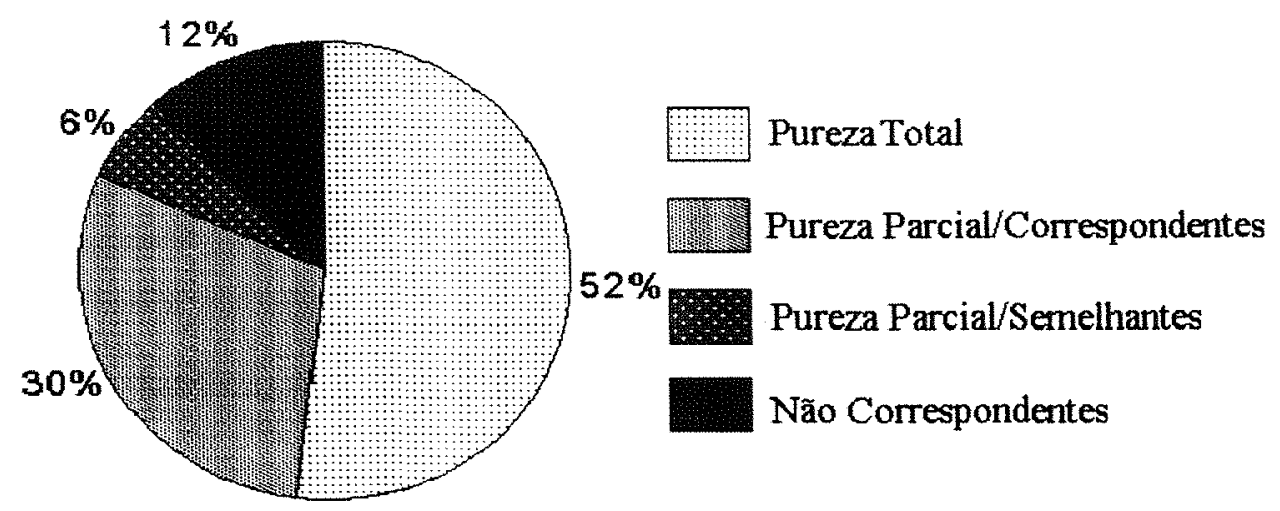

Figura 20- Gráfico mostrando as classes de pureza do mapa detalhado de solos-2000.

Apesar da boa correspondência existente entre as amostras externas e o mapa detalhado-2000 algumas explicações podem ser dadas para a elevada percentagem de amostras externa com classe de correspondência Pureza Parcial/Correspondentes, uma delas é a alta variabilidade (já discutida) de alguns atributos dos solos da MHCC, tais como, atividade da argila e saturação por bases e alumínio.

A não correspondência de algumas amostras (Não Correspondentes) pode ser explicada também pela variação de classes de solos em algumas topossequências em pendentes curtas, como, por exemplo, no caso da amostra externa de $n^{\circ} 45-$ NEOSSOLOS LITÓLICOS, que está localizada em uma unidade de mapeamento de 
ALISSOLOS CRÔMICOS, neste caso o ponto de amostragem estava localizado próximo de uma grota, não representativa cartograficamente, que apresenta solos rasos.

Uma das razões da melhor acurácia do mapa detalhado-2000, quando comparado com o mapa detalhado-1991, é que o mapeamento feito em 2000 já partiu de uma base de dados extremamente consistente, isto é, um mapa semidetalhado, escala 1:100.000, (Oliveira \& Prado, 1989), um mapa detalhado, escala 1:10.000, (Sparovek, 1991) e resultados analíticos em grande quantidade.

A diferença na quantidade de amostras, com resultados analíticos, entre os dois mapas é grande. De acordo com Embrapa (1995) os mapeamentos detalhados devem possuir 0,5 observações por hectare, e apresentar um perfil completo e dois perfis complementares por classe de solos no nível taxonômico mais baixo. Porém, observamos neste trabalho, que a quantidade de amostras a ser coletada num mapeamento, deve ser uma função da variância de alguns atributos da área a ser mapeada e não um valor tabelado. Pois corre-se o risco de sub-avaliar ou super-avaliar a quantidade de amostra a ser utilizada.

Ao Relacionar a precisão (variância) e a pureza (acurácia) das unidades de mapeamento (Tabela 7 e Tabela 19) do mapa detalhado de solos-2000 observa-se que as unidades de menor variabilidade (ACt1, PVAepp2, PVe e $N V e$ ) e maior variabilidade (RUbe) do mapa detalhado-2000 não apresentam amostragem externa. Avaliando a unidade $R L e 4$, que também apresenta alta variabilidade e foi checada por 6 amostras externas, observa-se que $\mathbf{8 3} \%$ das amostras são da classe Pureza total e $17 \%$ da classe Pureza parcial/Correspondentes, ou seja, $100 \%$ de alta pureza. Analisando-se a unidade de mapeamento $A C t q$, que apresenta variabilidade intermediária e foi checada com 2 amostras externas, nota-se que as duas amostras apresentam alta pureza (uma da classe Pureza total e outra Pureza parcial/Correspondentes). Estes resultados não são indicativos em relação à ocorrência ou não relação entre alta variabilidade e baixa pureza ou entre baixa variabilidade e alta pureza. 


\subsubsection{Avaliação geral da pureza}

Neste trabalho, o aumento do número de unidades de mapeamento do mapa detalhado de solos-2000 em relação ao mapa detalhado-1991, ambos na mesma escala, melhorou a pureza do mapa, o mesmo acontecendo quando se comparam os dois mapas detalhados-2000 e 1991 com o mapa semidetalhado, que apresenta uma quantidade muito menor de unidades de mapeamento e uma pureza menor. Bie \& Beckett (1973) encontraram purezas médias para unidades de mapeamento de: $32,1 \%$ para o pedólogo B; $47,0 \%$ para o pedólogo C; $56,2 \%$ para o pedólogo A; e $69,2 \%$ para o pedólogo D. Diferente deste trabalho, a tendência geral daquele experimento foi que o número de classes de solos e a pureza das unidades de mapeamento possuem relação aproximadamente inversa para três pedólogos.

Considerando-se a soma de Pureza Total e Pureza Parcial/Correspondentes, como Pureza média (Tabela 19), teremos valores de: $38 \%$ para o mapa semidetalhado; $54 \%$ para o mapa detalhado-1991; e 82\% para o mapa detalhado-2000.

Marsman \& Gruijter (1986) encontraram purezas médias variando entre 64\% e $70 \%$ para mapas de solo na escala 1:50.000. Mapas de solo na escala 1:10.000 têm pureza média entre $59 \%$ e $62 \%$. Os valores extremos são $34 \%$ e $100 \%$ para mapas de solo na escala 1:50.000. Para mapas de solo na escala 1:10.000 estes valores são 43\% e $84 \%$. Valores para pureza ppd (propriamente dita) são todos muitos baixos, variando entre $7 \%$ e $12 \%$. A pureza ppd é quando a classificação do perfil é exatamente igual à classificação da unidade de mapeamento.

Pureza $p p d$ no trabalho de Marsman \& Gruijter (1986) é igual à Pureza Total no presente trabalho. Porém, é importante ressaltar que o sistema de classificação de solos holandês é morfométrico, como consequência as classes de solos são definidas com vários atributos de solos. Isto significa que nos mapas detalhados $(1: 10.000)$ o nível de exigência da legenda é muito maior (maior detalhamento) que nos mapas semidetalhados (1:50.000). Isto tudo reflete na menor pureza dos mapas detalhados em relação aos semidetalhados. Também, justifica os menores valores de pureza ppd no trabalho de Marsman \& Gruijter (1986) em comparação ao nosso trabalho. 
A comparação de porcentagens de pureza de estudos diferentes tem algumas restrições. O nível de pureza alcançado depende fortemente do nível de classificação para a qual a pureza é calculada e no grau de detalhamento dos sistemas de classificação individuais.

Wilding et al. (1965) investigaram purezas para níveis diferentes de classificação para algumas unidades de mapeamento nos Estados Unidos. Os valores seguintes foram alcançados: grande grupo de solo, 96\%; subgrupo, $85 \%$; série, 42\%; tipo, 39\%. Para algumas outras unidades de mapeamento os valores foram: ordem, 74\%; grande grupo de solo, 44\%; subgrupo, 22\%; série, 17\% (McCormack e Wilding, 1969).

\subsubsection{Relação entre pureza e concordância dos mapas de solos}

A Tabela 20 mostra de forma resumida as classes de pureza da amostragem externa dos mapas de solos em estudo (Mapa Detalhado-2000 (D2000), Mapa Detalhado-1991 (D1991) e Mapa Semidetalhado (Semi).

Tabela 20- Resumo das Classes de Pureza dos mapas de solos.

\begin{tabular}{lccc}
\hline Classe de Pureza & Mapa Semi & Mapa D1991 & Mapa D2000 \\
\hline & 34 & 20 & 52 \\
Pureza Total & 4 & 34 & 30 \\
Pur. parcial/Correspondentes & 18 & 10 & 6 \\
Pur. parcial/Semelhantes & 44 & 36 & 12 \\
Não correspondentes & 100 & 100 & 100 \\
Total & & & \\
\hline
\end{tabular}

Como as Classes de Pureza foram avaliadas nos mapas de solos individuais, a relação com as classes de concordância dos mapas de sobreposição foi obtida utilizandose a classe Alta Pureza, quando a amostra externa apresentava Alta Pureza em ambos os mapas sobrepostos e a classe Baixa Pureza, quando a amostra externa apresentava Baixa Pureza em ambos os mapas sobrepostos ou em pelo menos um mapa. Por exemplo: a amostra externa $n^{0} 2$ apresenta de acordo com a Tabela 19, as classes de pureza 
Semelhantes no mapa Semidetalhado - Semi, Pureza Total no mapa Detalhado-2000 (D2000) e Pureza Total no mapa Detalhado-1991 (D1991), portanto, a amostra $\mathrm{n}^{0} 2$ apresenta a classe Alta Pureza no mapa resultante da sobreposição D2000 x D1991 e classe Baixa Pureza nos mapas resultante das sobreposições D2000 x Semi e D1991 x Semi. As classes de pureza das amostras externas foram observadas, independentemente e com somatório igual a 100\%, nas áreas com classes de concordância Alta Concordância e Baixa Concordância, como pode ser observado na Tabela 21.

Tabela 21- Relação entre a Classe de Pureza da amostragem externa e a concordância dos mapas de solos.
Classes de Concordância/
D2000 x Semi
D1991 x Semi D2000 x D1991

Classes de Pureza

Alta Concordância

38

38

48

Alta Pureza

82

64

79

Baixa Pureza

18

36

21

Baixa Concordância

62

62

52

\begin{tabular}{rlll} 
Alta Pureza & 44 & 33 & 40 \\
Baixa Pureza & 56 & 67 & 60 \\
\hline
\end{tabular}

A Tabela 21 mostra a relação entre as classes de pureza da amostragem externa e a concordância dos mapas de solos. Observa-se que nas classes de concordância Alta Concordância, que ocorrem em menos da metade das áreas das sobreposições dos mapas de solos, com $38 \%$, $38 \%$ e $48 \%$, respectivamente, para os mapas resultantes das sobreposições D2000 x Semi, D1991 x Semi e D2000 x D1991, apresentam amostras externas, dominantemente, com classes de pureza Alta Pureza com 82\%, 64\% e 79\% para as sobreposições acima. Por outro lado, nas classes de concordância Baixa Concordância que ocorrem em mais da metade das áreas das sobreposições dos mapas com $62 \%$, 62\% e 52\%, respectivamente para os mapas D2000 x Semi, D1991 x Semi e D2000 x D1991, apresentam amostras externas, dominantemente, com classes de pureza Baixa Pureza com 56\%, 67\% e $60 \%$ para as sobreposições acima. 
Os resultados apresentados na Tabela 21 e discutidos anteriormente, indicam que as áreas, dos mapas de concordância resultantes das sobreposições dos mapas de solos, em que ocorrem as classes de Alta Concordância, apresentam dominantemente classes de Alta Pureza. Sendo verdade também, que as áreas com classes de Baixa Concordância apresentam Baixa Pureza. Isto indica que estas duas medidas estão estreitamente relacionadas.

\subsection{Facilidade de leitura dos mapas de solos}

O uso dos mapas de solos é também influenciado pelos aspectos cartográficos que determinam a facilidade de leitura do mapa de solos. A facilidade de leitura também é uma forma de avaliação da qualidade do mapa. Este parâmetro é importante quando se consideram usuários tradicionais dos mapas de solos, apresentando menor importância para uso em SIGs.

Em geral usuários de mapas preferem mapas de solos com um número limitado de unidades de mapeamento, pois também não gostam de mapas cujas áreas delineadas são muito pequenas (Marsman \& Gruijter, 1986).

As informações básicas sobre legibilidade dos mapas de solos, que são: número de unidades de mapeamento, número de unidades de mapeamento delineadas, área das unidades de mapeamento e área média das unidades delineadas; estão presentes nas Tabelas 4, 5 e 6 (itens 3.2, 3.3 e 4.1.1) e são apresentadas resumidamente na Tabela 22.

Tabela 22- Informações sobre facilidade de leitura dos mapas de solos.

\begin{tabular}{lccc}
\hline Mapa de solos & $\begin{array}{c}\text { Nos Unidades de } \\
\text { mapeamento }\end{array}$ & $\begin{array}{c}\text { Nos } \\
\text { delineadas }\end{array}$ & $\begin{array}{c}\text { Unidades Área média das unidades } \\
\text { delineadas (ha) }\end{array}$ \\
\hline Detalhado-2000 & 46 & 115 & 16,90 \\
Detalhado-1991 & 31 & 111 & 17,51 \\
Semidetalhado & 8 & 9 & 215,91 \\
\hline
\end{tabular}


Os dados apresentados na Tabela 22 mostram claramente um aumento no número de unidades de mapeamento e unidades delineadas quando se compara o mapa de solos semidetalhado com os mapas de solos detalhados. Observa-se, também, no mesmo sentido, uma redução significativa da área média das unidades delineadas com o aumento do detalhamento.

Para o usuário tradicional, isto é, usuários sem acesso a SIGs, o mapa semidetalhado é de mais fácil leitura e interpretação para outros usos. Marsman \& Gruijter (1986) observaram que a legibilidade melhora consideravelmente se os mapas de solos são generalizados, porque o número de áreas delineadas é reduzida e elas tornam-se maiores, porém o nível de informações também é reduzido.

Observando-se os mapas de solos detalhados, nota-se que ambos apresentam praticamente o mesmo número de unidades delineadas e área média das unidades delineadas, no entanto, a quantidade de unidades de mapeamento do mapa detalhado2000 é quase $50 \%$ maior que do mapa detalhado-1991. Esta maior quantidade de unidades de mapeamento reduz a facilidade de leitura do mapa, porém aumenta a precisão e acurácia do mapa. 


\section{CONCLUSÕES}

- Os solos com horizonte B textural são dominantes na microbacia, ocupando $43 \%$ da área, com predomínio dos ALISSOLOS CRÔMICOS (20\%). Os NEOSSOLOS LITÓLICOS ocorrem em $35 \%$ da microbacia.

- Houve dificuldades em mapear os solos com horizonte B textural, ao nível de ordem no Sistema Brasileiro de Classificação de Solos, devido a alta variabilidade dos atributos de solos, em curta distância, utilizados na classificação, tais como: atividade de argila; saturação por bases; e saturação por alumínio.

- A variação da saturação por alumínio $(\mathrm{m})$, maior nas unidades de mapeamento do que na microbacia como um todo, foi atribuída à variações de curta distância no material de origem e aos processos erosivos.

- O detalhamento do mapa de solos foi eficiente em reduzir a variância dos atributos de solos dentro das unidades de mapeamento e dos mapas, aumentando assim a precisão dos mapas.

- O mapeamento de solos, para uso em modelos matemáticos que necessitam de baixa variância de seus atributos, é pouco eficiente devido a elevada variância na microbacia, mesmo a curtas distâncias;

- A concordância entre o mapa semidetalhado e os mapas detalhado-2000 e detalhado-1991 é muito baixa, demonstrando que o mapa semidetalhado não é uma simplificação do mapa detalhado. A complexa distribuição de solos na microbacia estudada contribuiu para este resultado. 
- A baixa concordância entre os mapas detalhados associada à menor variação do mapa detalhado-2000 em relação ao mapa detalhado-1991, indicaram que o mapeamento foi influenciado pelos recursos disponíveis (cartográficos e amostras analisadas) e pela equipe executora.

- Ocorreu um aumento da pureza (acurácia) do mapa semidetalhado para os mapas detalhados, sendo que o mapa detalhado-2000 apresentou maior acurácia que o mapa detalhado-1991.

- A concordância entre os mapas esteve diretamente relacionada à pureza, indicando que estas duas medidas estão estreitamente relacionadas.

- A facilidade de leitura do mapa aumenta no sentido: mapa detalhado-2000< mapa detalhado-1991 < mapa semidetalhado, porém a precisão e acurácia aumentam no sentido inverso. Isto sugere que a qualidade do mapa avaliada pela sua facilidade de leitura, atributo de interesse para determinados usuários, não está relacionada à qualidade dos mapas como medida por sua precisão e acurácia.

- O levantamento detalhado de solos-2000 deu subsídios para sugerir a criação de algumas classes de solos no Sistema Brasileiro de Classificação de Solos. Ao nível de subordem - NEOSSOLOS INDIFERENCIADOS; ao nível de grande grupo ARGISSOLOS VERMELHO-AMARELOS Ta Distróficos e NEOSSOLOS LITÓLICOS Álicos; e ao nível de subgrupo - ALISSOLOS CRÔMICOS Argilúvicos abrúpticos arênicos, ALISSOLOS CRÔMICOS Argilúvicos abrúpticos lépticos, ARGISSOLOS VERMELHO-AMARELOS Alumínicos abrúpticos, ARGISSOLOS VERMELHO-AMARELOS Alumínicos abrúpticos arênicos, ARGISSOLOS VERMELHO-AMARELOS Alumínicos abrúpticos lépticos, ARGISSOLOS VERMELHO-AMARELOS Distróficos abrúpticos arênicos, ARGISSOLOS VERMELHO-AMARELOS Distróficos abrúpticos lépticos, ARGISSOLOS VERMELHO-AMARELOS Eutróficos abrúpticos arênicos, ARGISSOLOS VERMELHO-AMARELOS Eutróficos abrúpticos lépticos, LUVISSOLOS CRÔMICOS Pálicos arênicos abrúpticos, LUVISSOLOS CRÔMICOS Órticos abrúpticos e NITOSSOLOS VERMELHOS Eutróficos argissólicos. 
ANEXOS 


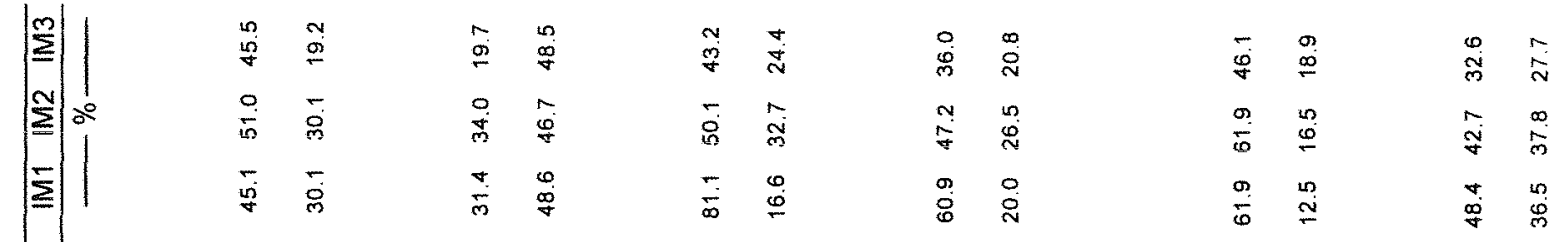

E |

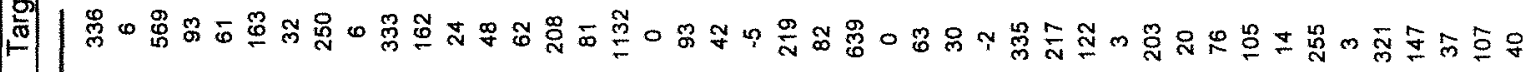
U

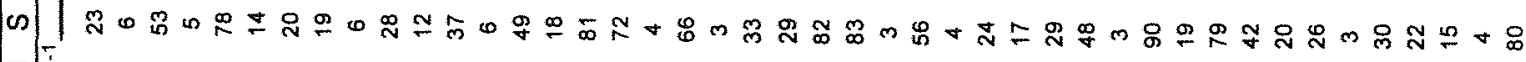

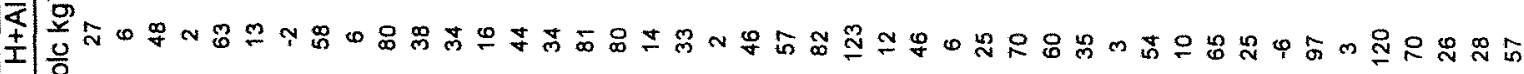

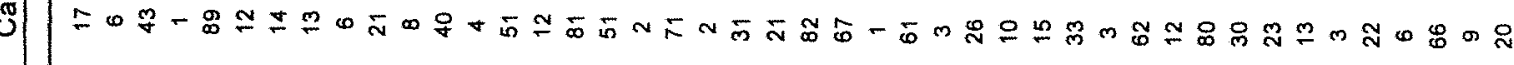

勿 要 N

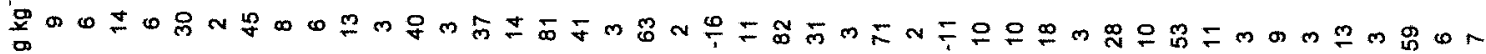

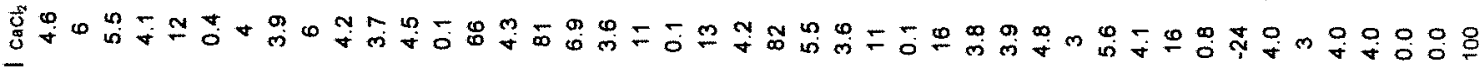

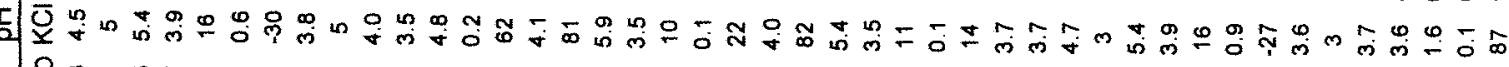

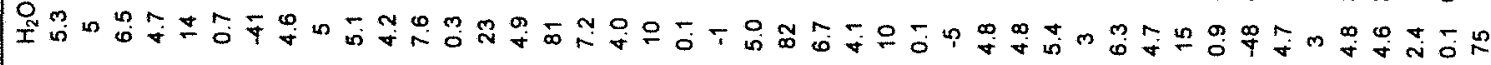

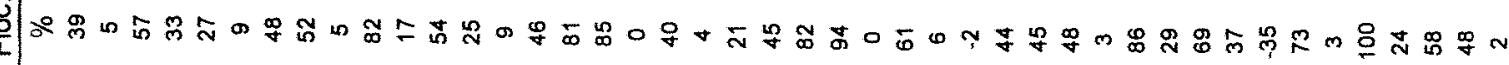
œ

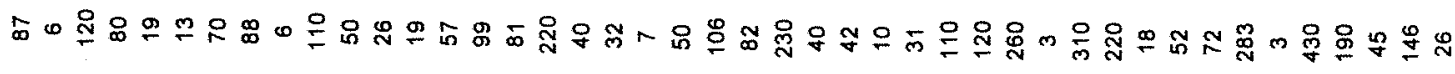

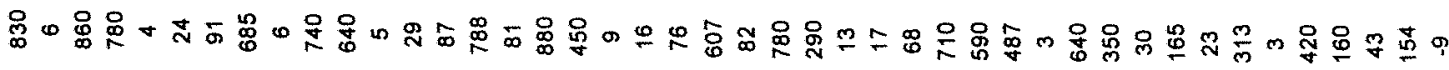
进心总喿

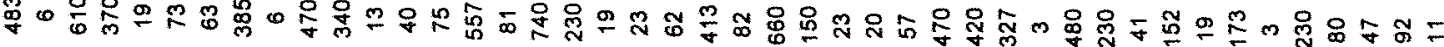

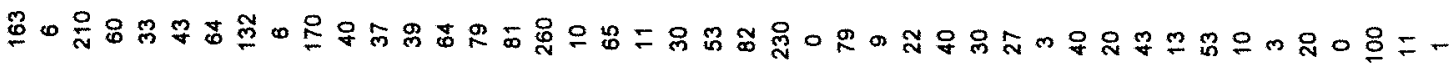

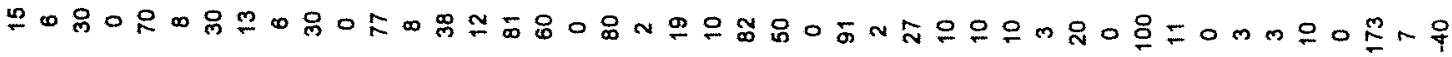

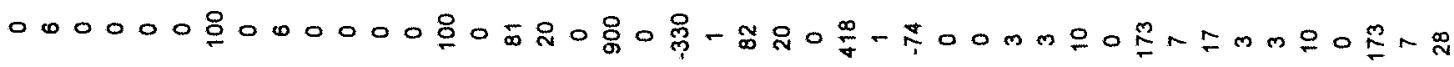

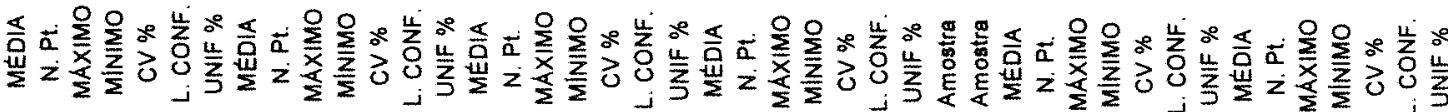




\begin{tabular}{|c|c|c|c|c|c|c|c|c|c|c|c|}
\hline$\sum$ & $\overline{5}$ & $\begin{array}{l}0 \\
\stackrel{0}{0}\end{array}$ & $\bar{r}$ & $\stackrel{\infty}{\stackrel{\infty}{N}}$ & 怘 & $\underset{d}{d}$ & $\frac{n}{*}$ & $\stackrel{m}{m}$ & 离 & $\stackrel{\infty}{\infty}$ & $\stackrel{\sim}{\aleph}$ \\
\hline$\stackrel{N}{\Sigma} \stackrel{\circ}{\circ}$ & $\frac{1}{6}$ & $\stackrel{\circ}{\stackrel{N}{N}}$ & $\stackrel{0}{*}$ & $\stackrel{\Delta}{\stackrel{4}{4}}$ & 落 & $\stackrel{N}{N}$ & $\begin{array}{l}n \\
\mathscr{B}\end{array}$ & $\underset{\infty}{\sim}$ & $\ddot{0}$ & $\ddot{\omega}$ & $\bar{g}$ \\
\hline$\sum$ & 웅 & 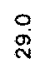 & m) & $\stackrel{\infty}{\stackrel{\infty}{N}}$ & 竡 & $\stackrel{m}{m}$ & $\underset{\hat{0}}{\stackrel{0}{0}}$ & $\stackrel{m}{\infty}$ & $\frac{n}{5}$ & $\underset{N}{N}$ & $\stackrel{m}{m}$ \\
\hline
\end{tabular}

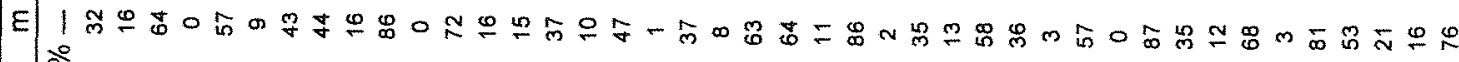
$>$ |

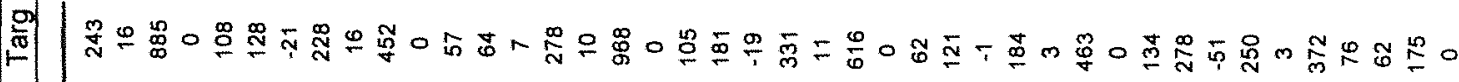

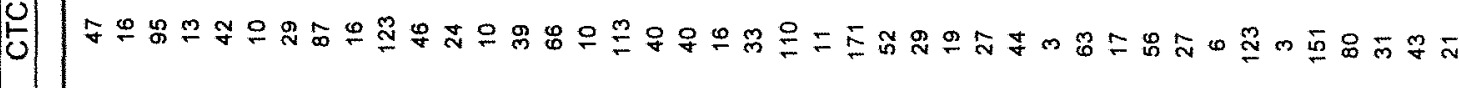
(1)

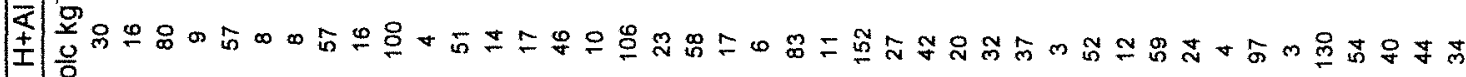
ব ร) U

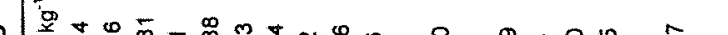
苞

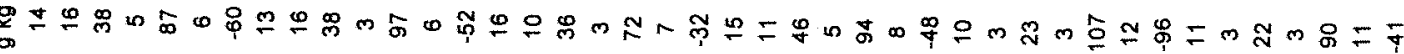

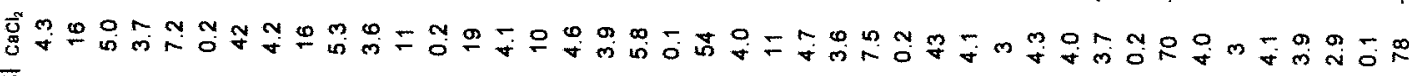

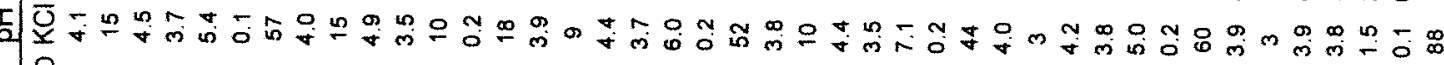

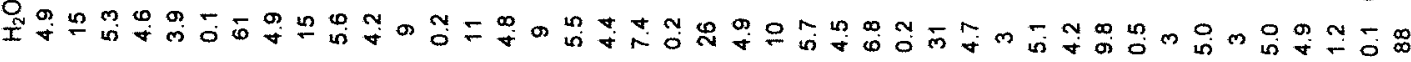

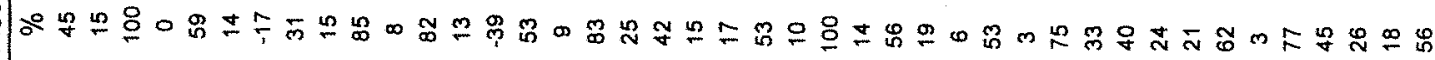

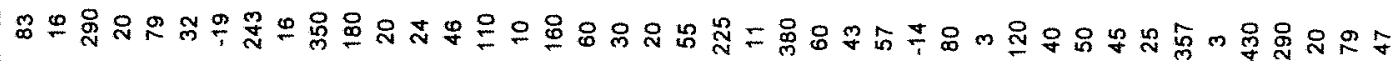
๓

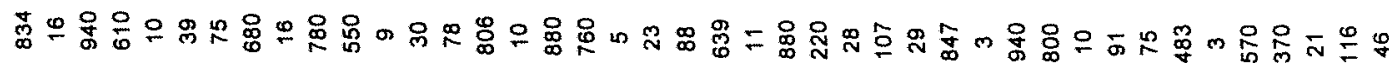

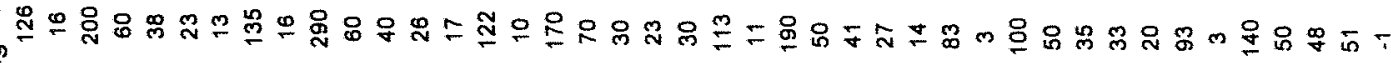

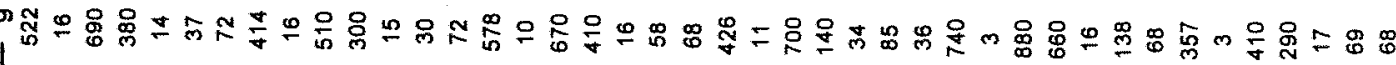

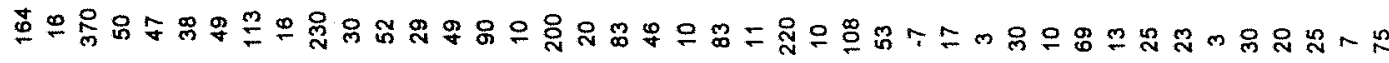

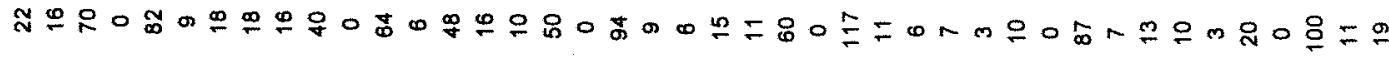

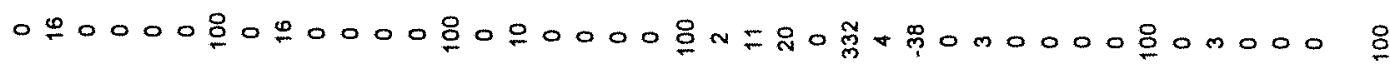

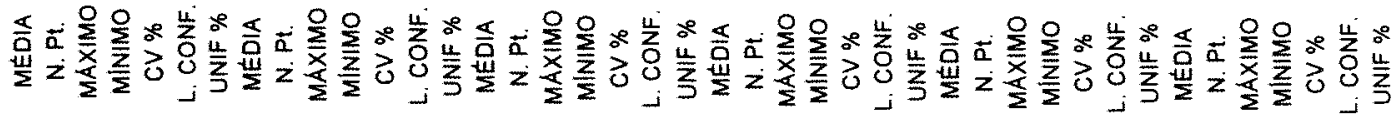




\begin{tabular}{|c|c|c|c|c|c|c|c|c|c|c|c|}
\hline$\sum_{\Sigma}^{m} \mid$ & $\begin{array}{l}\infty \\
\text { in } \\
0\end{array}$ & $\begin{array}{l}m \\
0\end{array}$ & 今; & $\begin{array}{l}\circ \\
0\end{array}$ & 离 & $\bar{\forall}$ & $\stackrel{\mathscr{m}}{\mathbb{8}}$ & $\stackrel{m}{\stackrel{m}{N}}$ & $\begin{array}{l}N \\
\text { ले }\end{array}$ & $\stackrel{m}{\dot{m}}$ & ल \\
\hline$\stackrel{N}{=} \div$ & $\begin{array}{l}\circ \\
\stackrel{8}{g}\end{array}$ & D̃ & 亩 & 今) & 广் & $\begin{array}{l}\infty \\
\infty \\
\infty\end{array}$ & $\hat{\dot{\theta}}$ & $\begin{array}{l}\stackrel{0}{\dot{v}} \\
\dot{v}\end{array}$ & $\stackrel{\mathscr{f}}{\mathrm{j}}$ & $\begin{array}{l}0 \\
\stackrel{9}{q}\end{array}$ & $\begin{array}{l}\infty \\
\infty \\
\infty\end{array}$ \\
\hline$\sum$ & $\stackrel{m}{\sigma}$ & 㭆 & 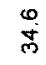 & 号 & 茴 & 虫 & 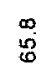 & $\stackrel{\circ}{=}$ & $\begin{array}{l}\circ \\
\dot{q}\end{array}$ & $\stackrel{\circ}{\ddot{g}}$ & 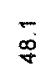 \\
\hline
\end{tabular}

E |

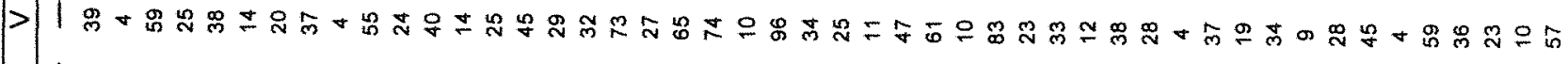

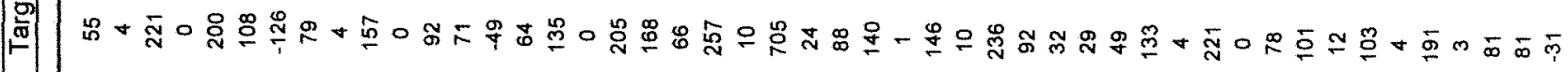

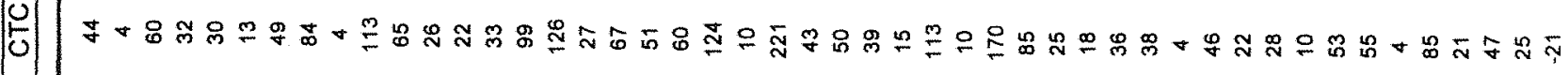

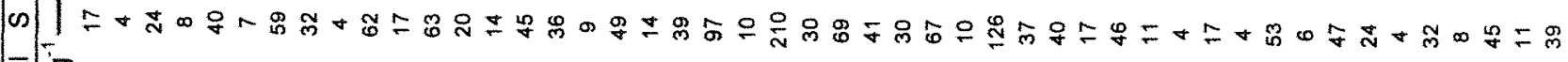

反

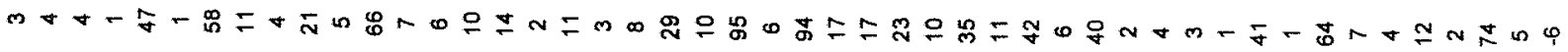

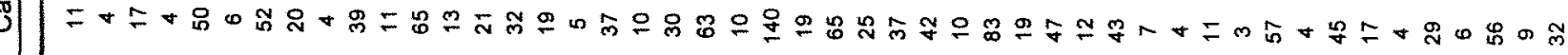

m

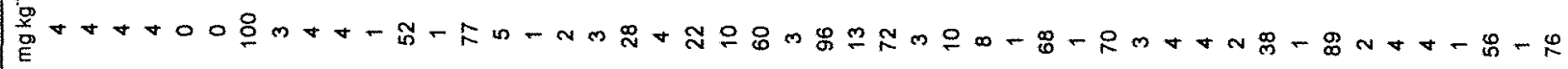

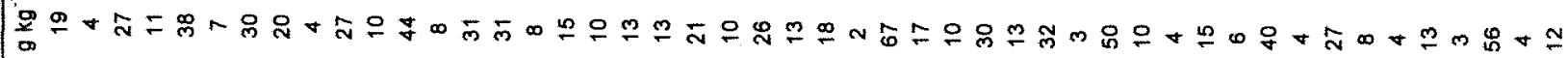

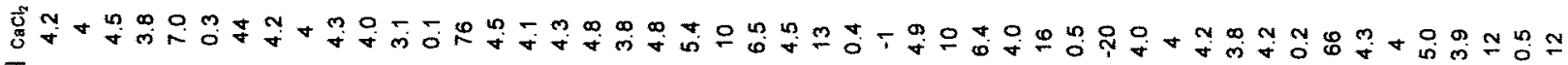

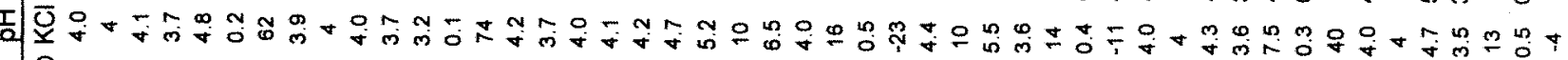

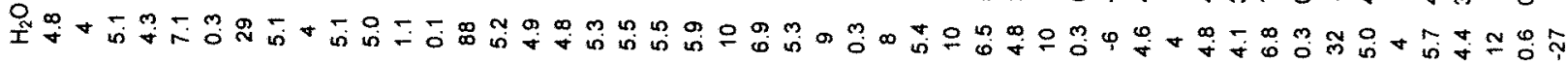

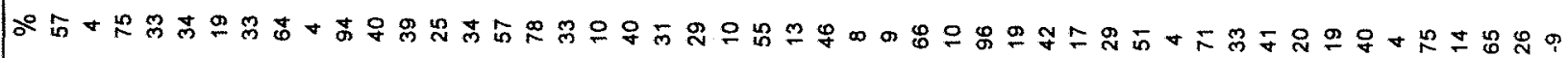

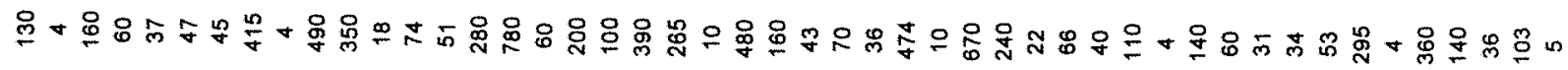

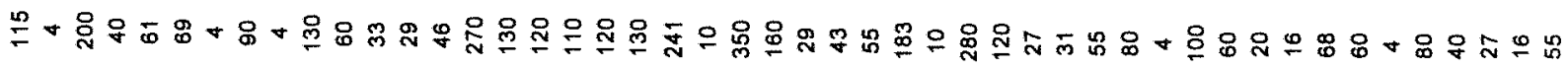

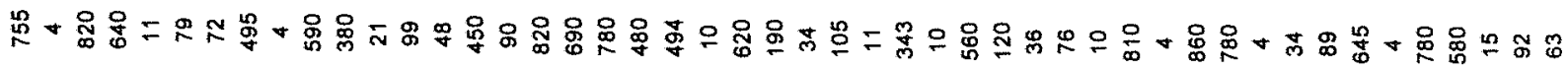

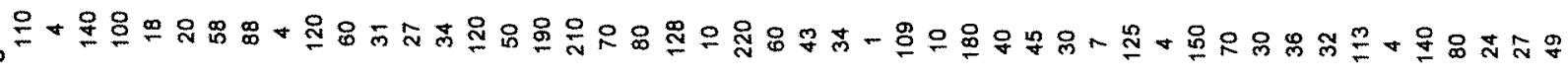

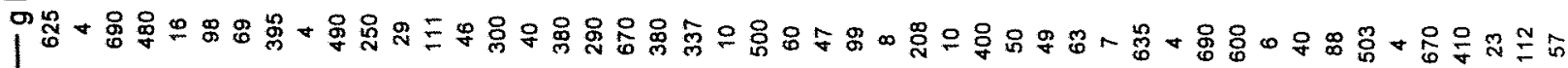

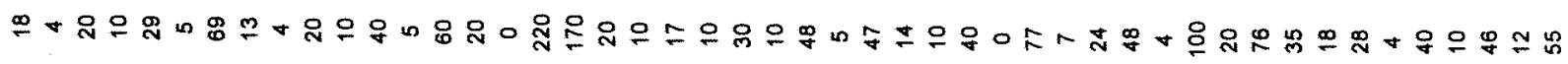

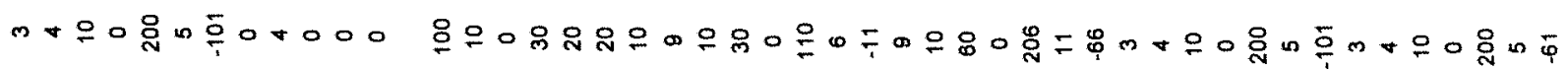

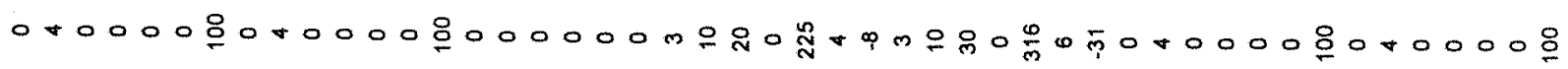

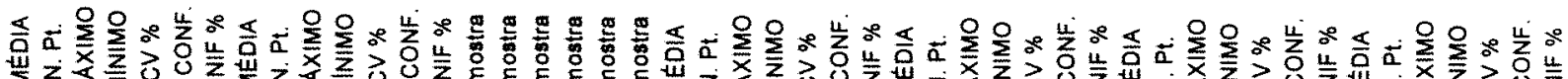

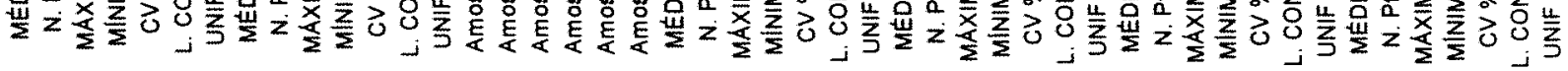

$\infty$

$\sum_{\substack{a \\ L}}^{\bar{\pi}}$

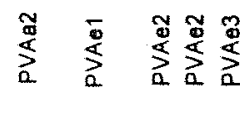




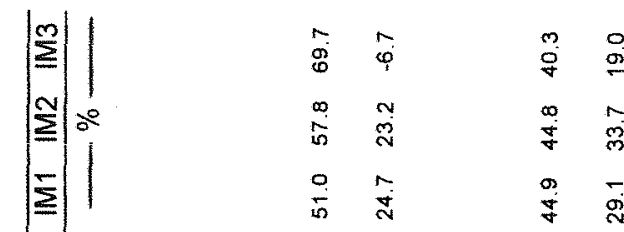

E|

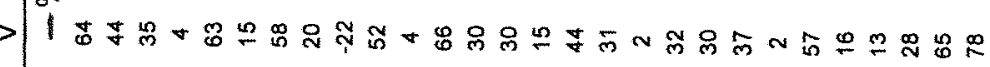

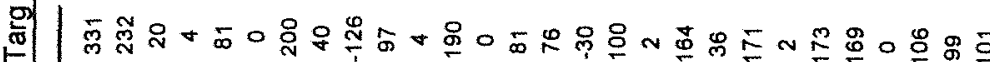

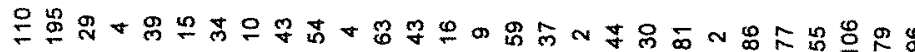

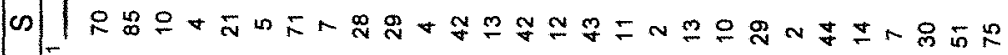

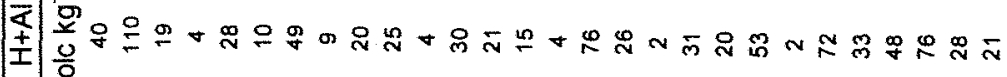

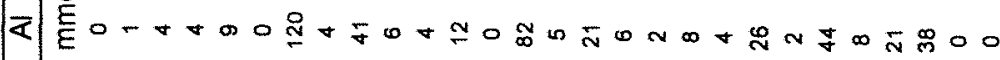

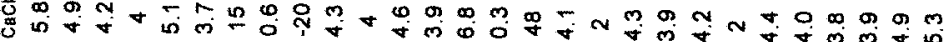

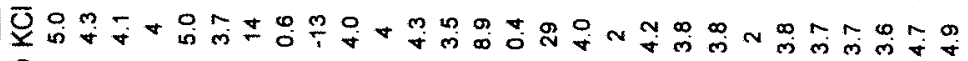

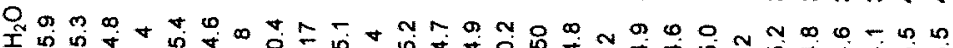

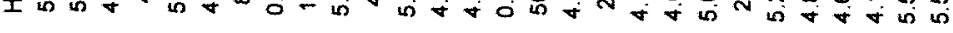

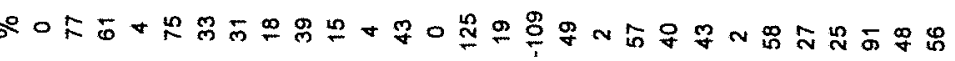

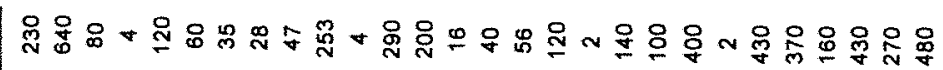

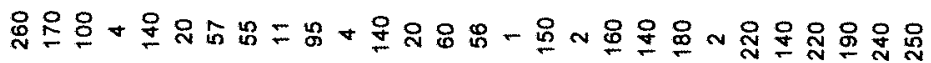

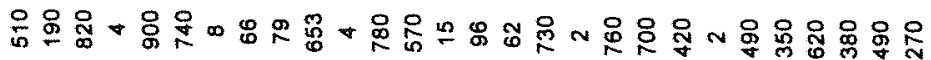

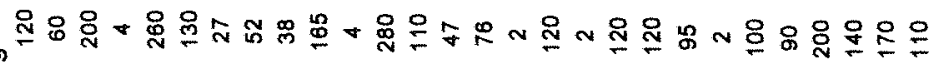

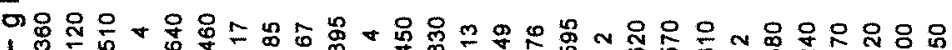

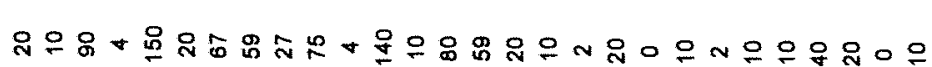

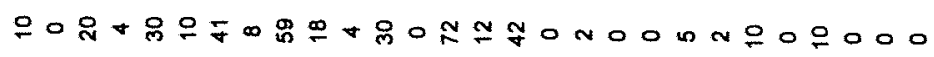

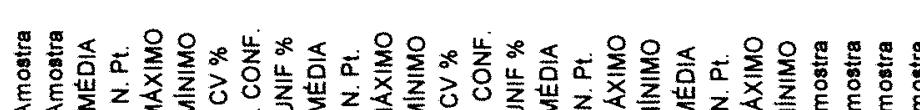

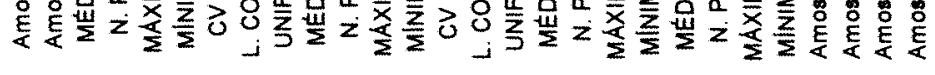

$<\infty<\infty$

$<\infty$ $\sum_{0}^{\bar{x}}$ $<\infty<\infty$

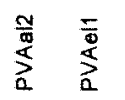

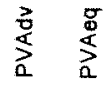
o o o $0000804000080 N 000 N 000000$

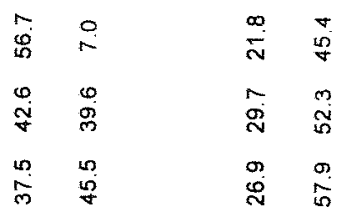

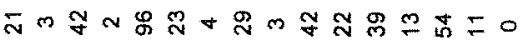

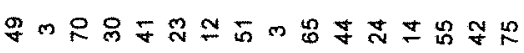

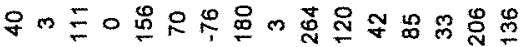

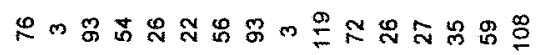

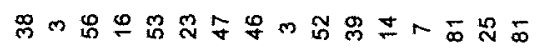

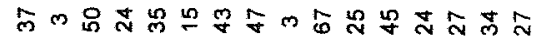

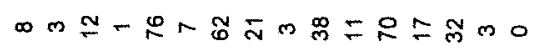

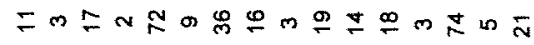

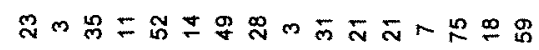

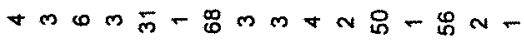

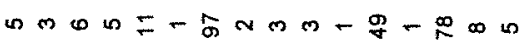

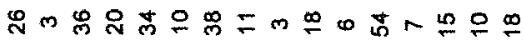

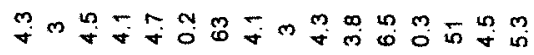

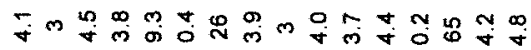

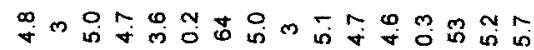

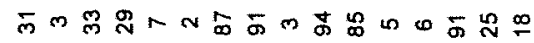

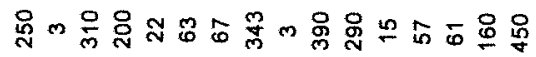

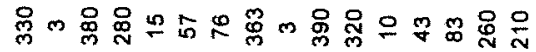

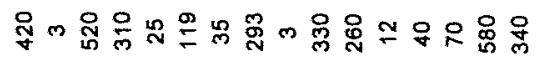

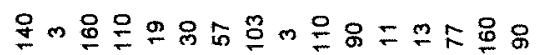

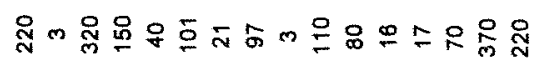

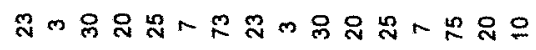

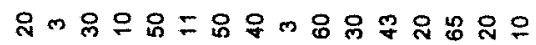

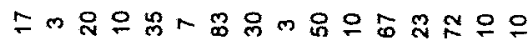

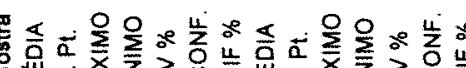

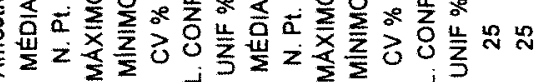

$\frac{\alpha}{2}$ $<\infty$ $\sum_{0}^{\frac{9}{6}}$ 


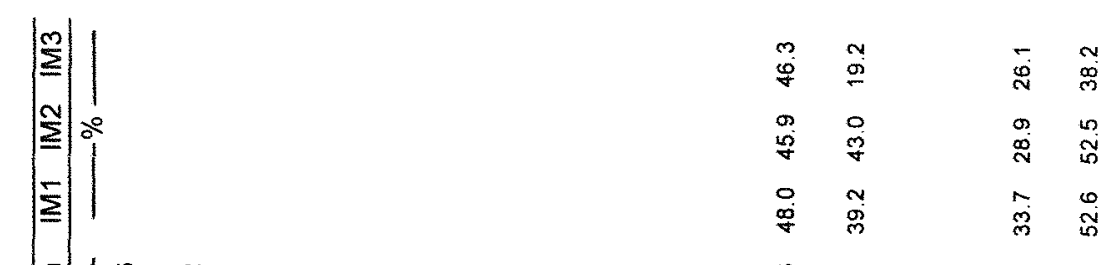

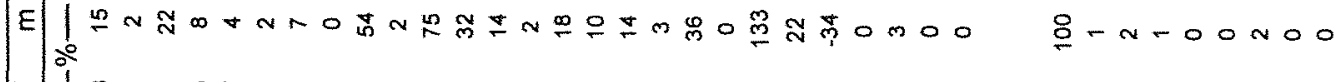

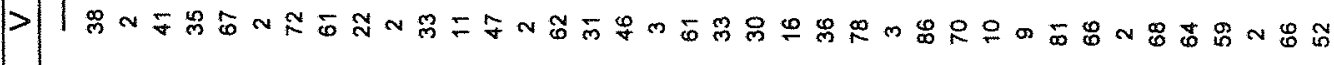

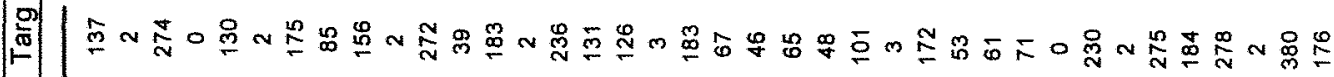
U 0 |

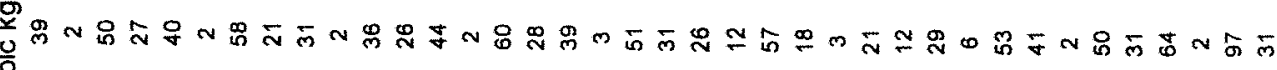

on Nํำ

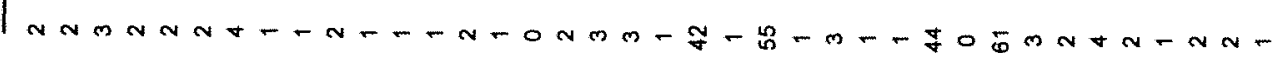
im D N

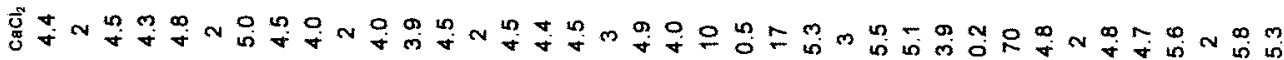
I밈ำ 足员

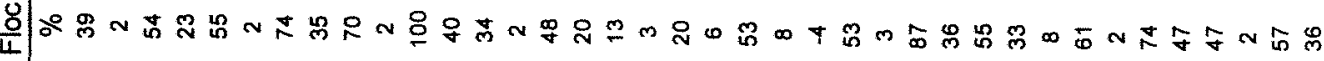

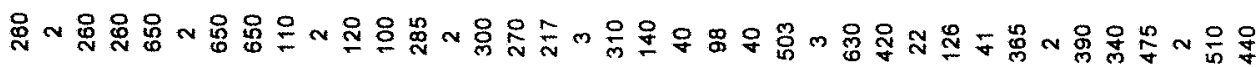

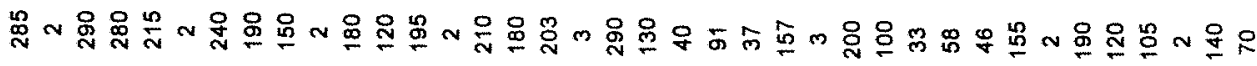

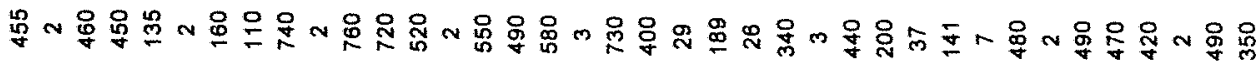

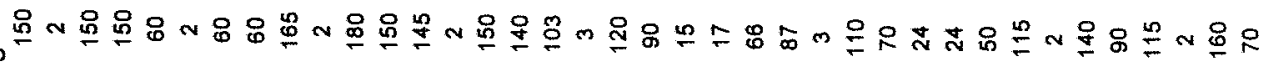

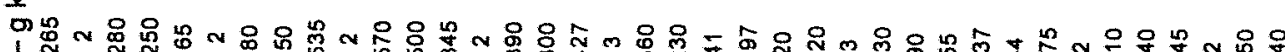

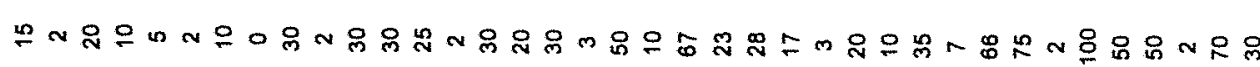

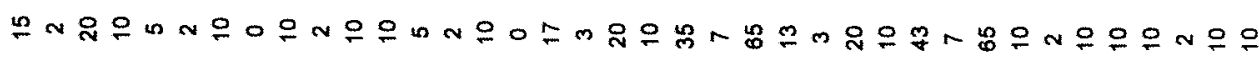
on

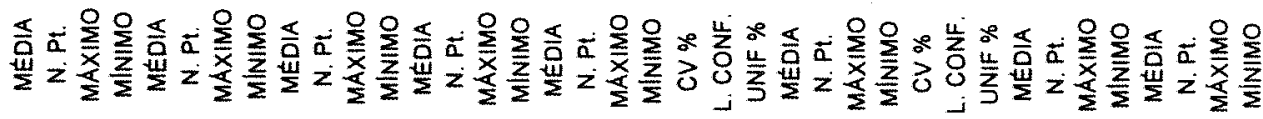
者 $\infty$ $\infty$ $\infty$ $\infty$ 


\begin{tabular}{|c|c|c|c|c|c|c|c|c|c|c|c|}
\hline 光 & 号 & $\underset{\bar{N}}{\bar{N}}$ & 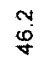 & $\underset{\square}{\mathbb{I}}$ & $\hat{0}$ & $\stackrel{\infty}{\infty}$ & $\stackrel{m}{\forall}$ & $\stackrel{\sigma}{\longrightarrow}$ & $\stackrel{0}{\stackrel{0}{\sigma}}$ & $\hat{\tilde{v}}$ & $\stackrel{i}{n}$ \\
\hline$=10$ & $\stackrel{\circ}{\circ}$ & $\stackrel{\infty}{\stackrel{\infty}{\sigma}}$ & $\bar{i}$ & 今్ & दे & 洜 & 象 & $\stackrel{N}{\stackrel{N}{O}}$ & 足 & $\begin{array}{l}\infty \\
\stackrel{\sim}{u}\end{array}$ & $\stackrel{\mathrm{m}}{\mathrm{m}}$ \\
\hline & $\stackrel{m}{\infty}$ & $\underset{\substack{0 \\
\sim}}{\sim}$ & 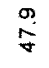 & $\underset{\sim}{m}$ & 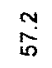 & $\stackrel{\infty}{\stackrel{\infty}{N}}$ & $\begin{array}{l}\text { 足 } \\
\text { 足 }\end{array}$ & $\stackrel{\mathscr{Y}}{\underline{y}}$ & $\begin{array}{l}\circ \\
\stackrel{0}{\sigma}\end{array}$ & $\underset{n}{N}$ & స్ల \\
\hline
\end{tabular}

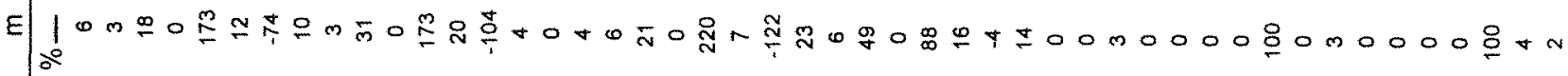

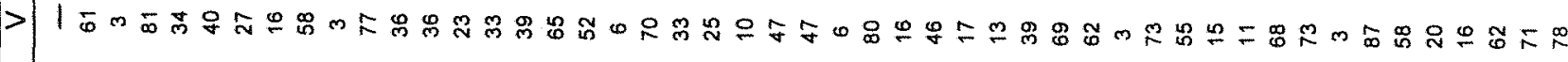

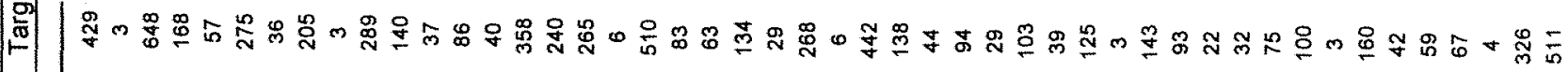

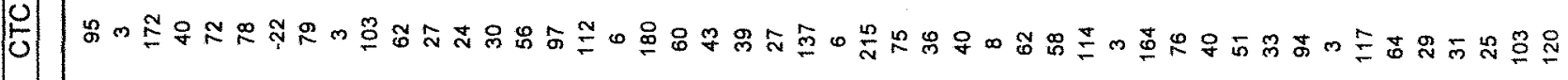
の |

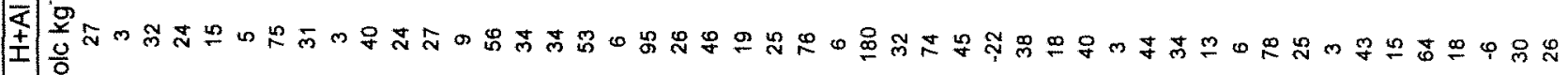
ব

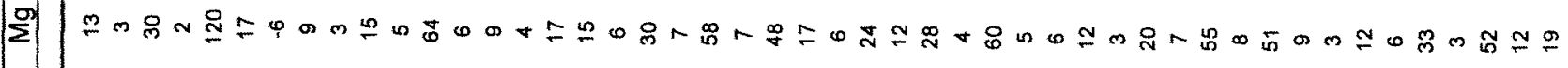

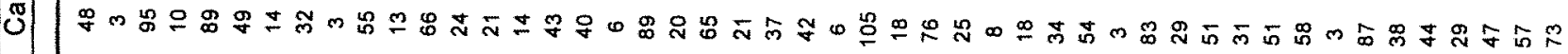

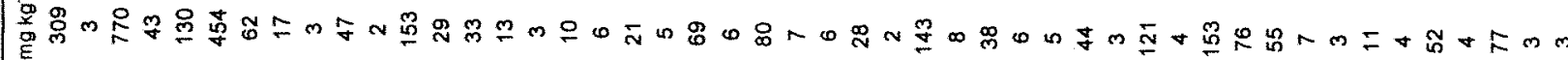

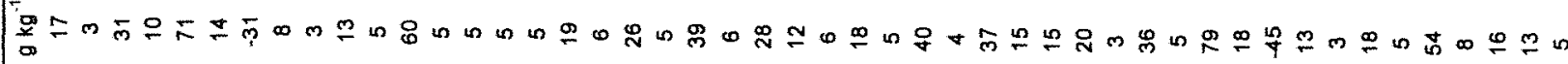

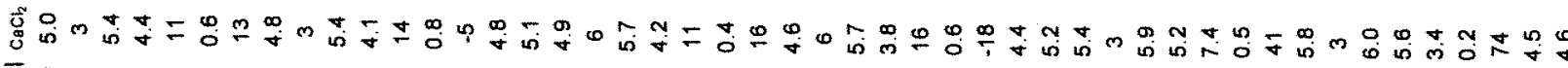

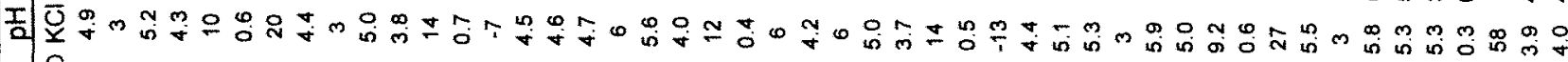

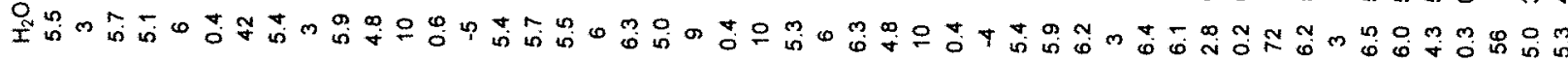

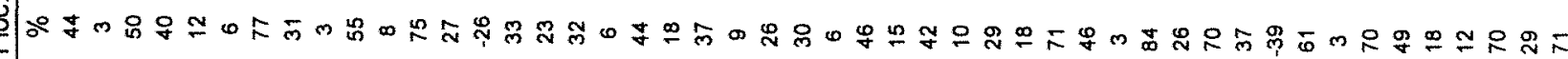

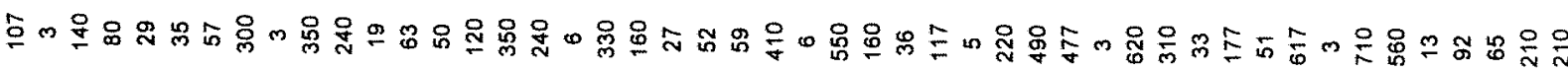

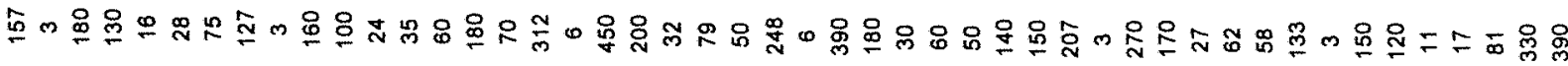

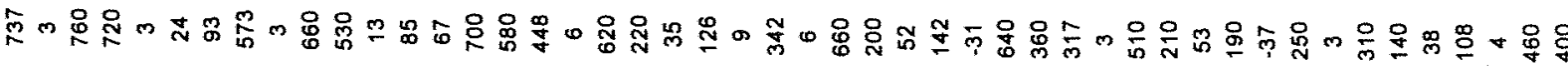

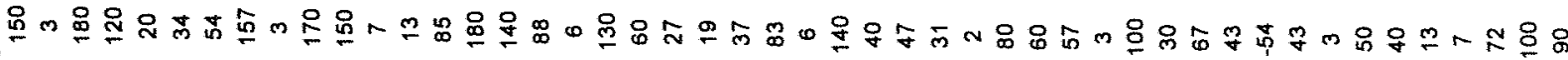

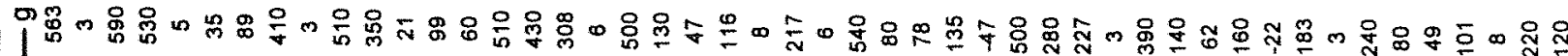

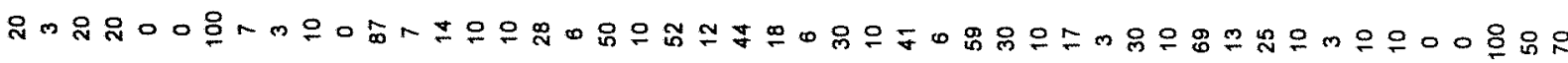

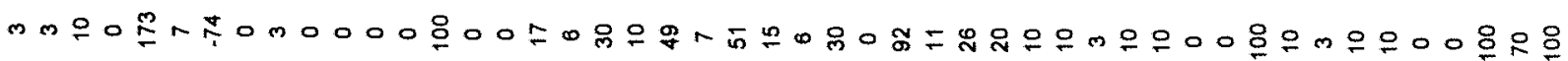

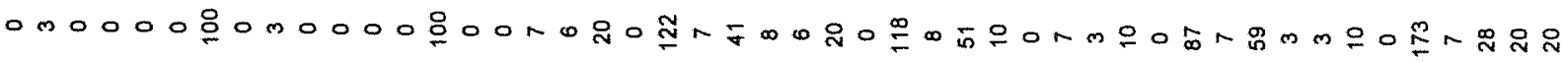

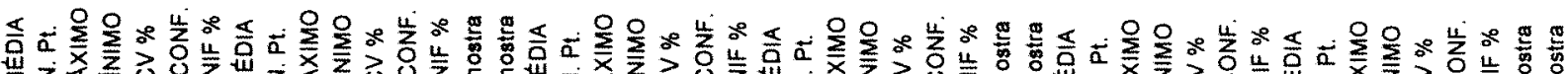

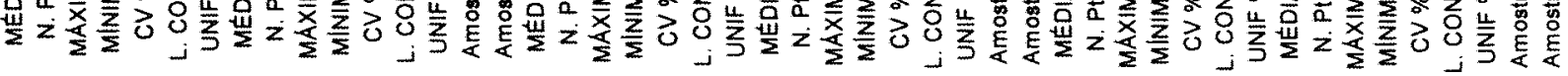




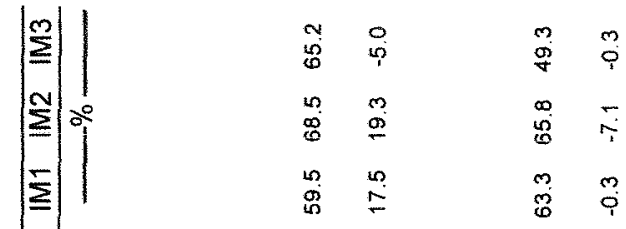

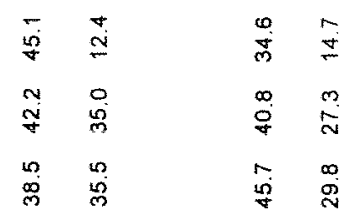

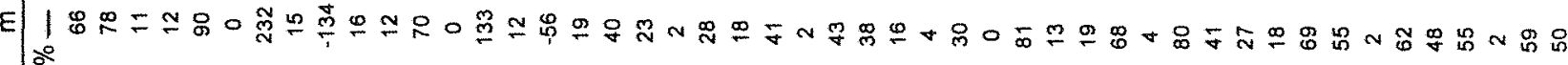
|

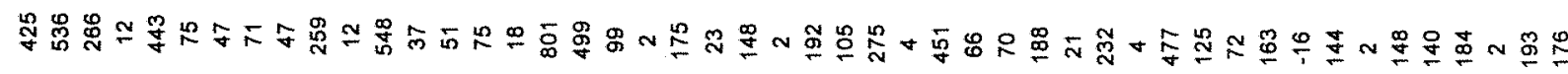

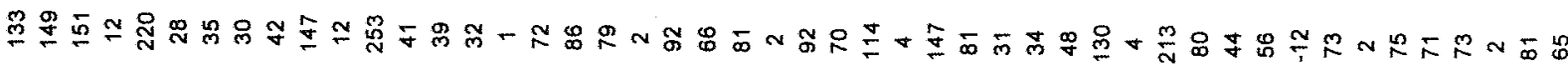

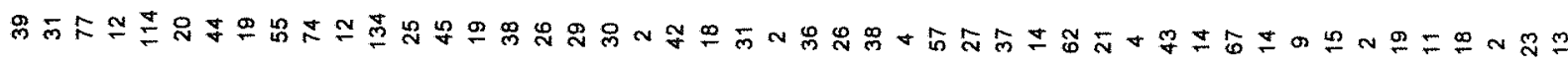

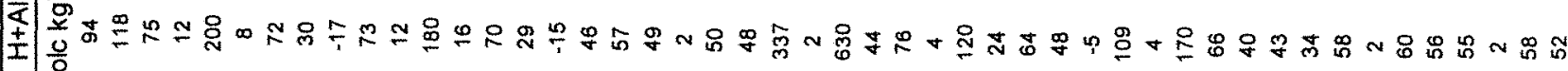

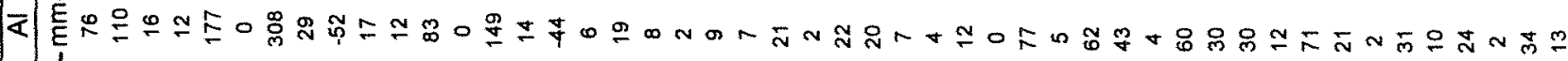
ก

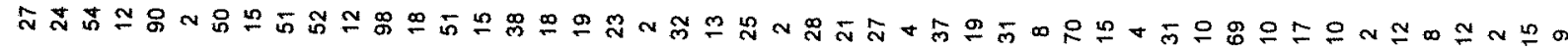

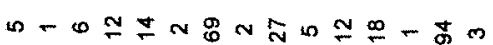

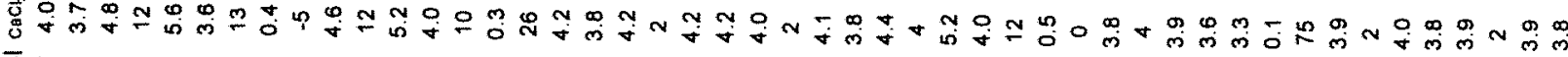

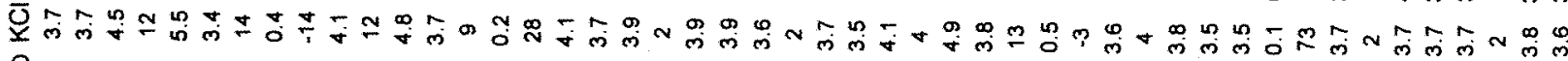

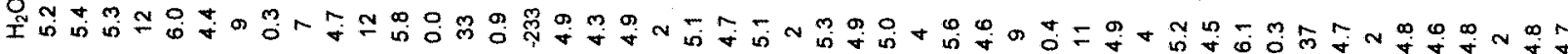

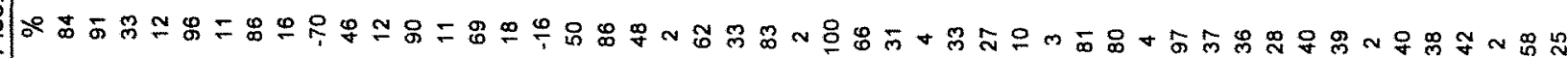

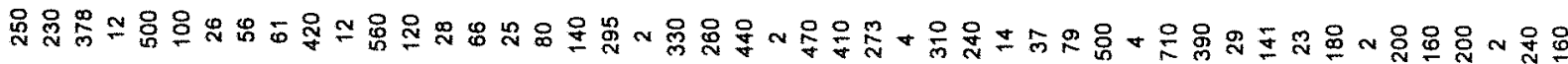

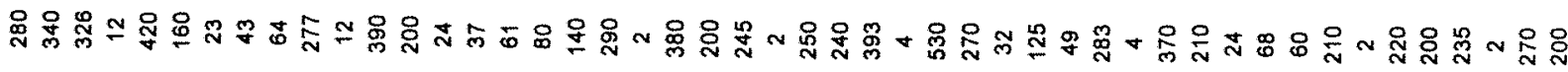

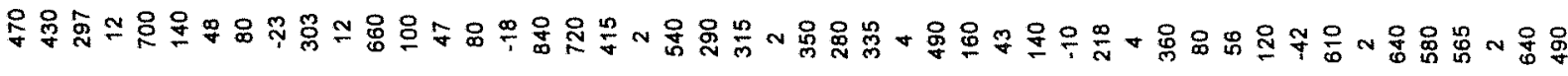

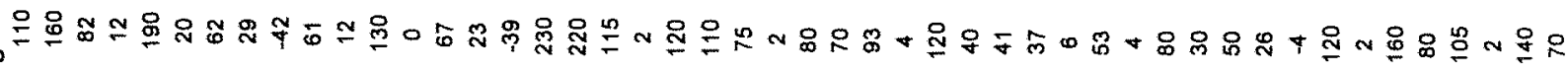

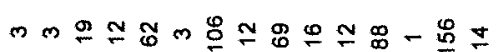

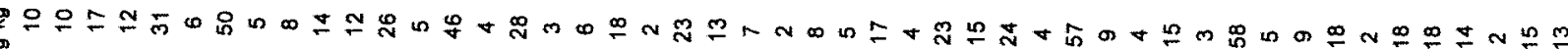

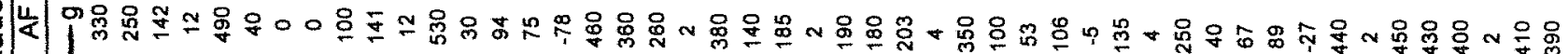

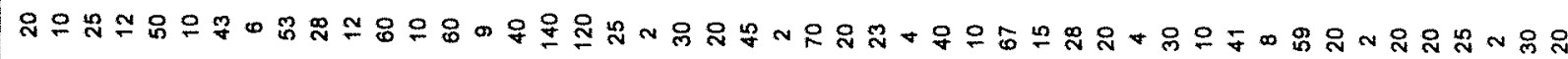

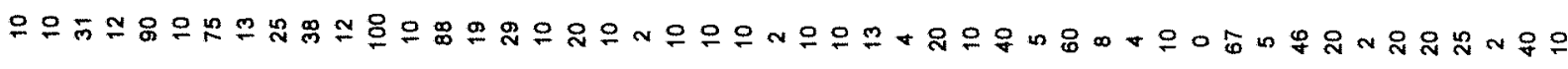

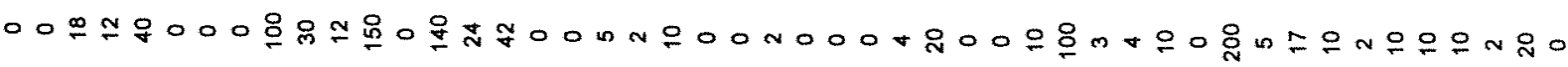

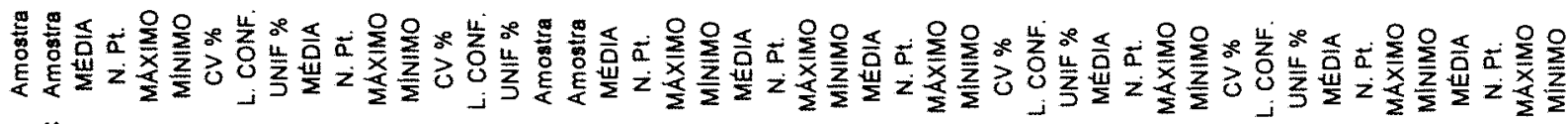
$<\frac{0}{\mathrm{~m}}<$

$\infty$

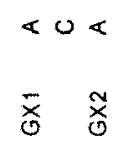$$
0
$$

0

$\varangle$

뚱

资

중

$\stackrel{\mathbb{a}}{x}$

$\stackrel{\infty}{x}$ 


\begin{tabular}{|c|c|c|c|c|c|c|c|c|c|c|c|}
\hline$\sum^{2}$ & $\underset{⿱ 亠 乂}{\sigma}$ & in & $\widehat{408}$ & $\underset{\infty}{m}$ & $\stackrel{N}{\mathbb{J}}$ & ì & 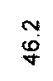 & N & $\overline{v i g}$ & $\hat{\bar{N}}$ & is \\
\hline$\sum$ & 哭 & ్ָ & 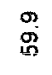 & $\stackrel{m}{\stackrel{m}{m}}$ & 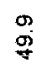 & $\begin{array}{l}\infty \\
0 \\
0 \\
0\end{array}$ & $\begin{array}{l}0 \\
0 \\
0 \\
0\end{array}$ & $\begin{array}{l}0 \\
\stackrel{0}{0}\end{array}$ & त्र & $\frac{m}{m}$ & $\frac{0}{N}$ \\
\hline$\underline{\underline{\Sigma}}$ & $\sqrt{5}$ & $\stackrel{\mathscr{N}}{\mathrm{N}}$ & $\begin{array}{l}\text { 我 } \\
\text { in }\end{array}$ & $\stackrel{\tilde{\infty}}{\cong}$ & g্ & $\stackrel{\infty}{\infty}$ & 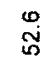 & $\stackrel{+}{\varrho}$ & $\stackrel{m}{0}$ & $\underset{\sim}{\stackrel{d}{d}}$ & $\stackrel{\hat{\theta}}{\hat{\theta}}$ \\
\hline
\end{tabular}

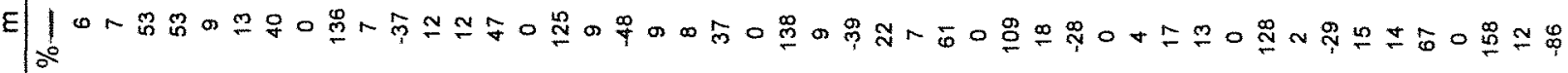

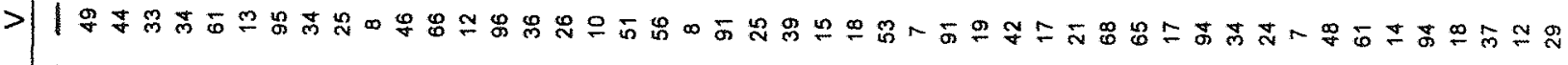

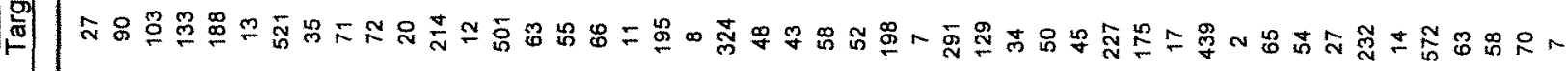

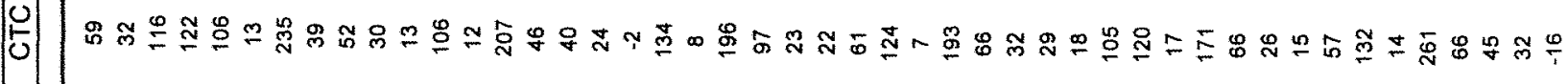

の|ำ

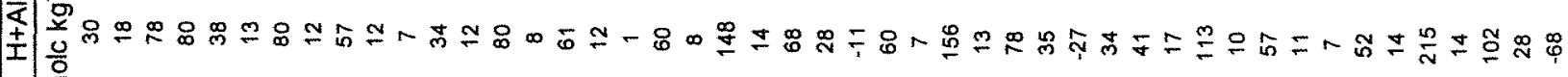

区

I

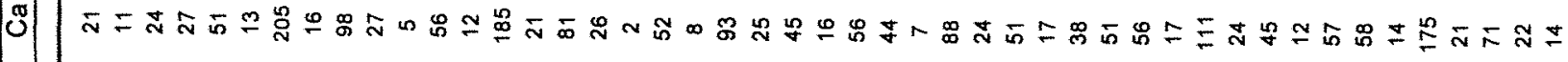

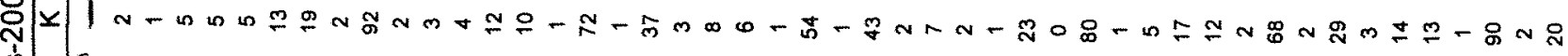

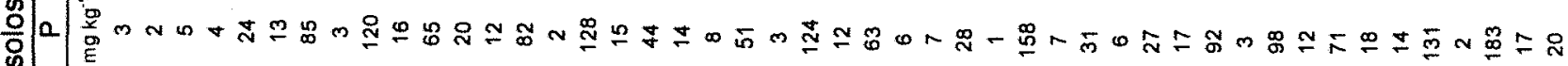

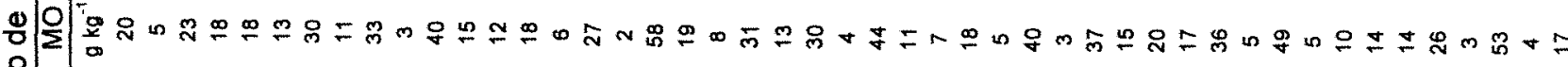

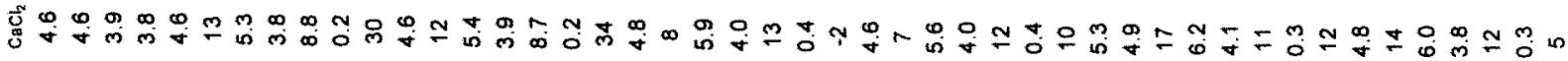

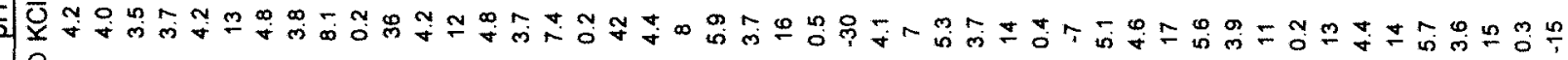

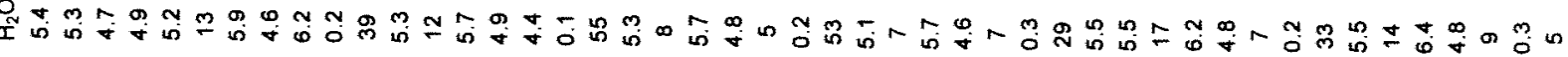

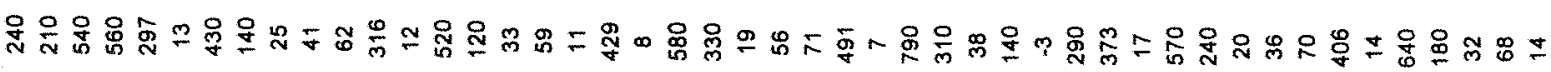

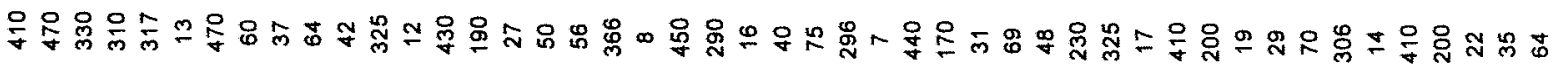

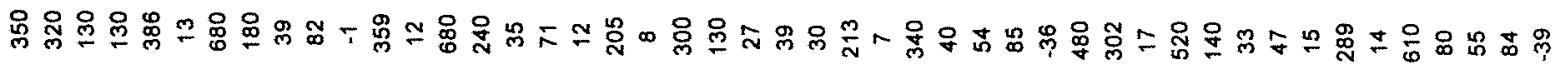

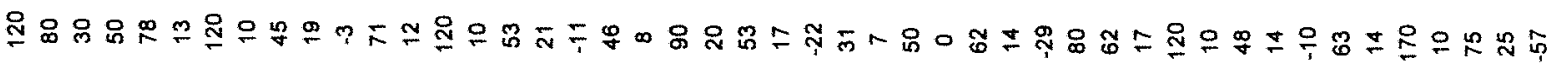

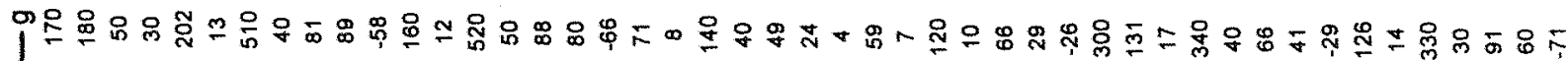

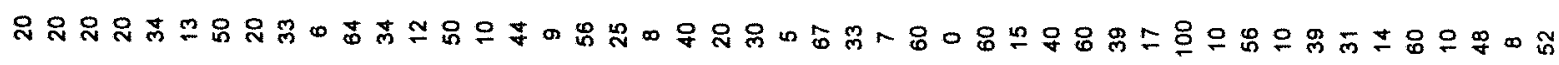

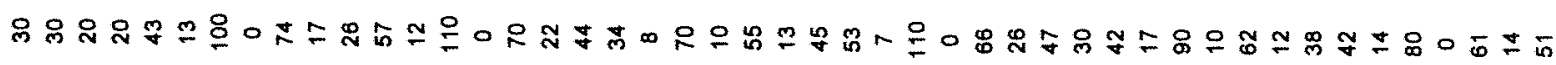

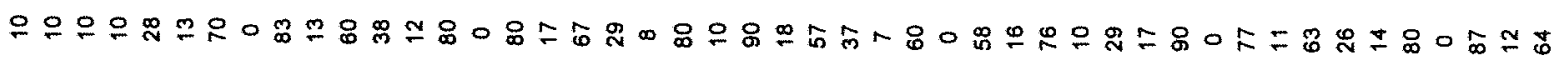

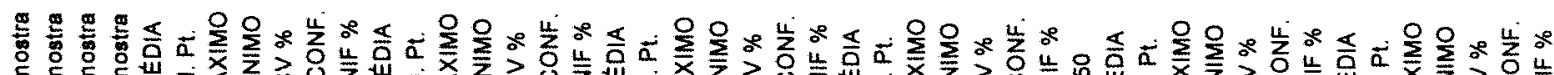

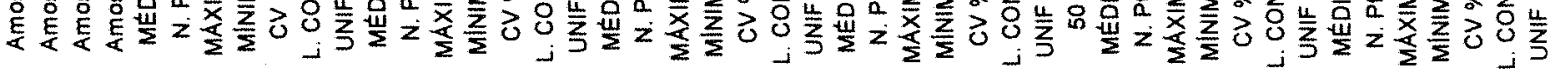
皆 $<0<$

$\stackrel{\leftrightarrow}{0}$

$<$

药

\&

땅

$\overline{\vec{x}} \frac{\sqrt{y}}{\vec{\alpha}} \overline{\frac{d}{\alpha}}$

$\stackrel{\Xi}{ณ}$ 


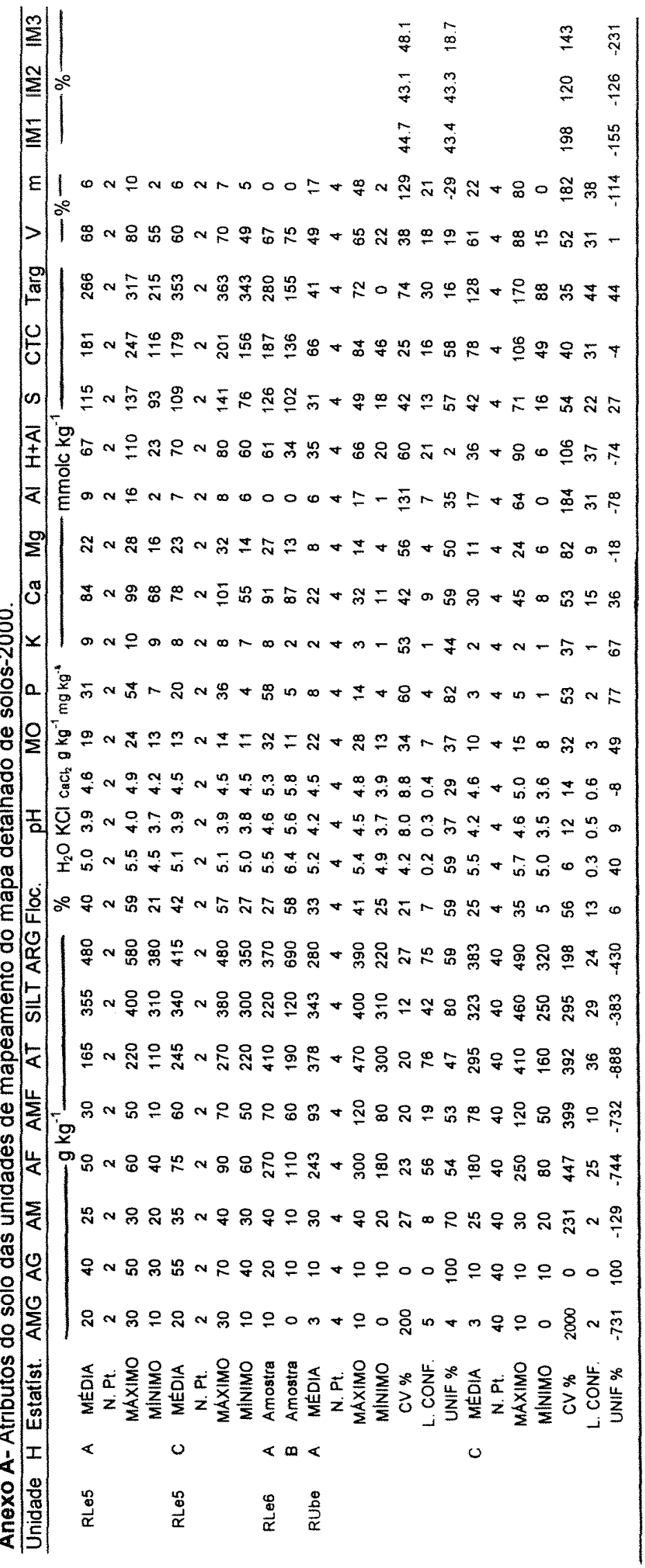




\begin{tabular}{|c|c|c|c|c|c|c|c|c|c|c|c|c|}
\hline$\stackrel{m}{m}$ & Ni & $\stackrel{0}{i}$ & 品 & $\begin{array}{l}\dot{\sigma} \\
\stackrel{\sigma}{\circ}\end{array}$ & $\begin{array}{l}\stackrel{v}{7} \\
\forall\end{array}$ & $\stackrel{5}{\dot{c}}$ & 免 & 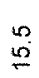 & $\begin{array}{l}0 \\
\stackrel{5}{5}\end{array}$ & $:$ & $\begin{array}{l}0 \\
\stackrel{q}{q}\end{array}$ & $\stackrel{0}{\stackrel{D}{\mathbb{N}}}$ \\
\hline$\sum i^{2}$ & $\stackrel{N}{\infty}$ & $\stackrel{N}{N}$ & $\underset{N}{N}$ & is & $\stackrel{?}{*}$ & $\stackrel{N}{N}$ & 该 & $\begin{array}{l}\infty \\
\stackrel{\infty}{\sim}\end{array}$ & $\begin{array}{l}\mathscr{0} \\
\stackrel{0}{0}\end{array}$ & $\stackrel{\Upsilon}{=}$ & $\overrightarrow{8}$ & $\stackrel{\mathscr{O}}{=}$ \\
\hline$\sum$ & 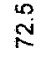 & $\int_{0}^{0}$ & : & $\begin{array}{l}3 \\
\infty\end{array}$ & 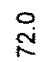 & $\begin{array}{l}\sim \\
\stackrel{N}{\sigma}\end{array}$ & $\begin{array}{l}\infty \\
0 \\
8\end{array}$ & $\stackrel{\leftrightarrow}{\dot{t}}$ & 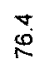 & is & $\stackrel{N}{N}$ & $\underset{\infty}{N}$ \\
\hline
\end{tabular}

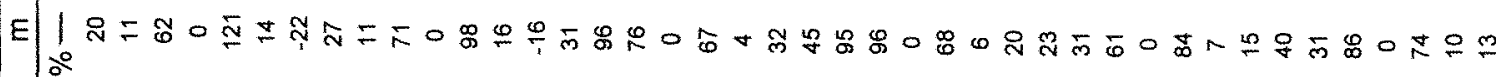

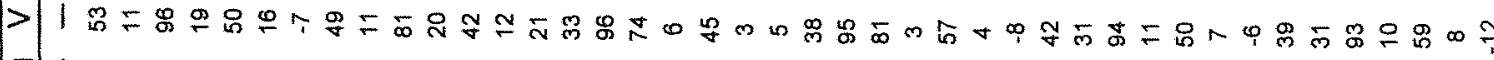

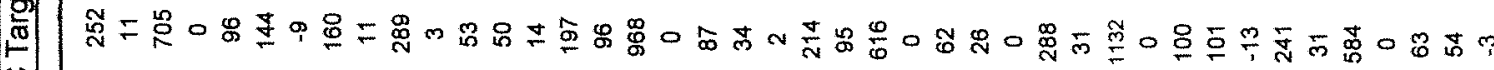
卢

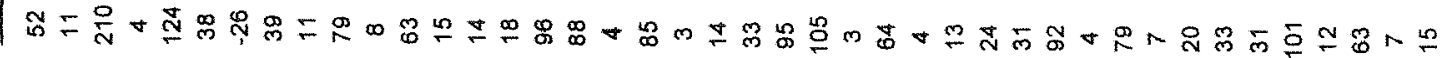
윰듀 0

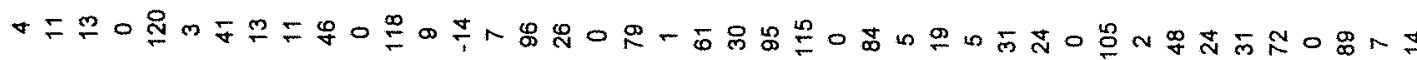
|ํㅠ

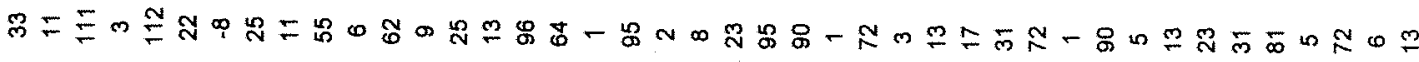
ง

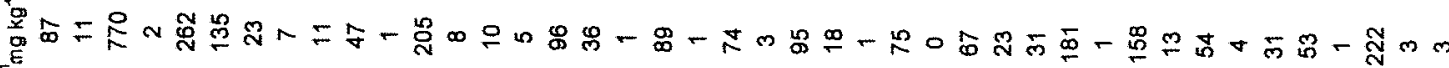

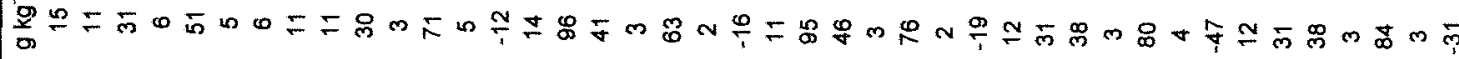

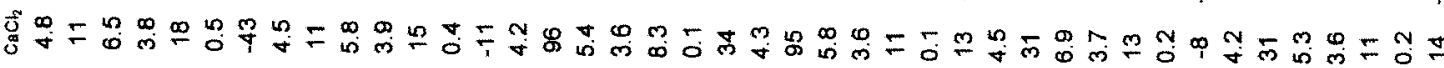

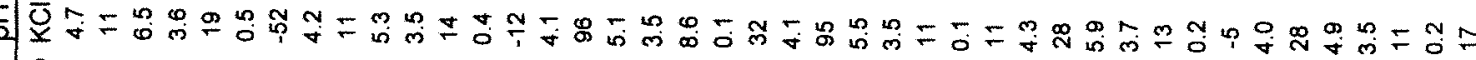
全 N 원ำ

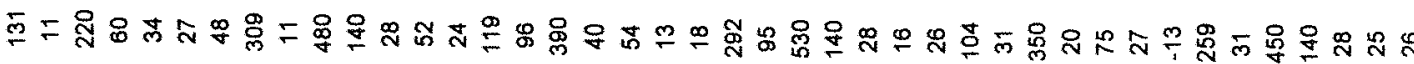

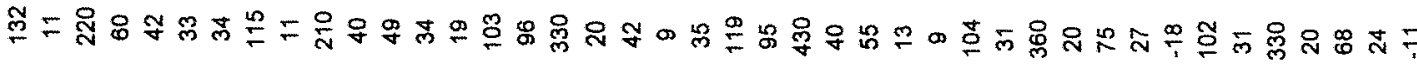

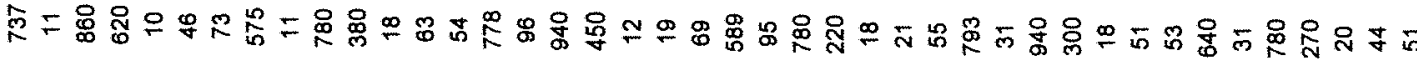

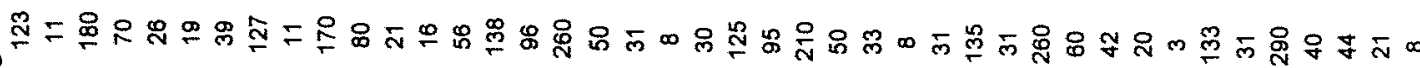

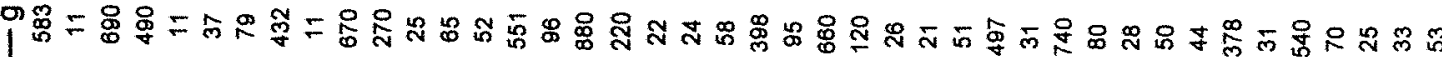

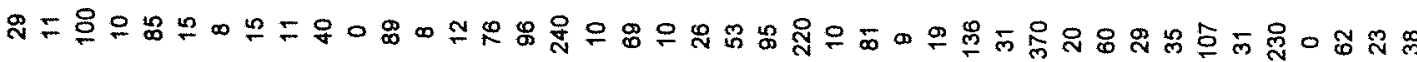

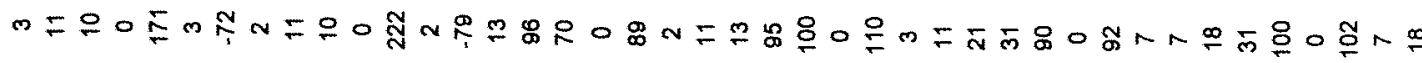

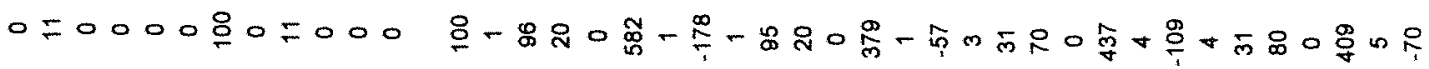

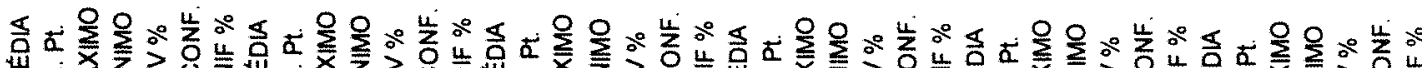

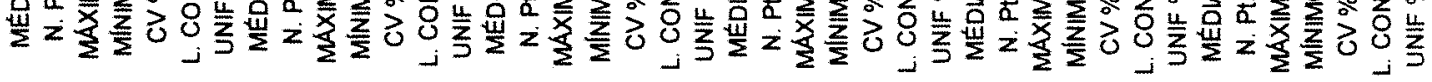

$\infty$

京
$<$

$\$$ $\infty$ $\ll$ 


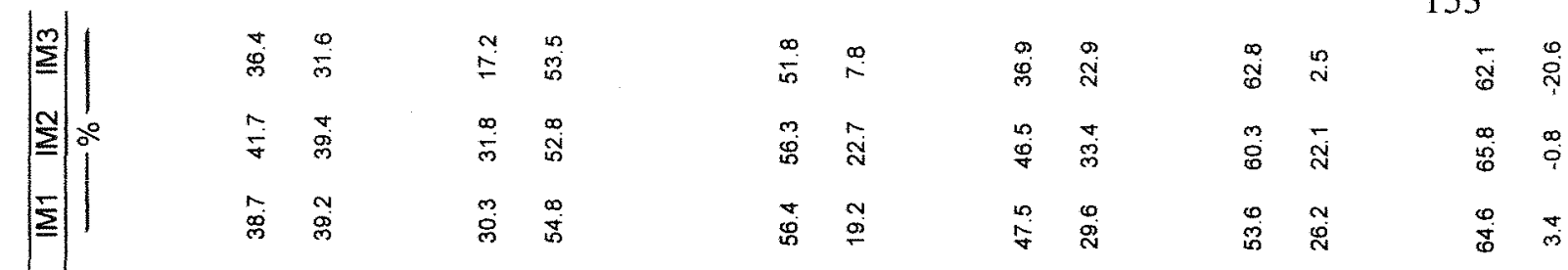

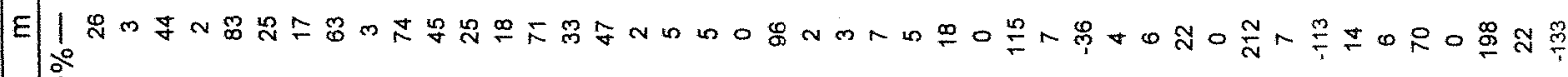
$>\mid$ |

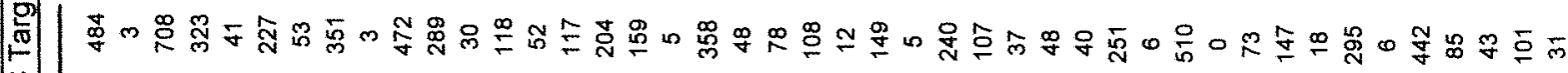

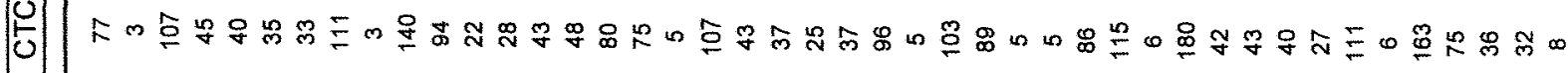

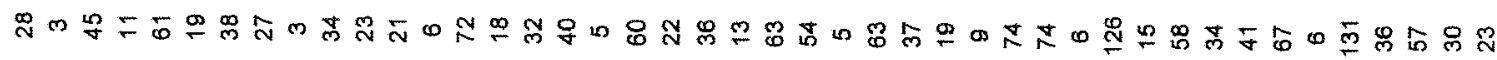

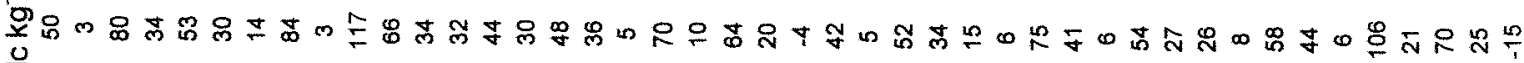

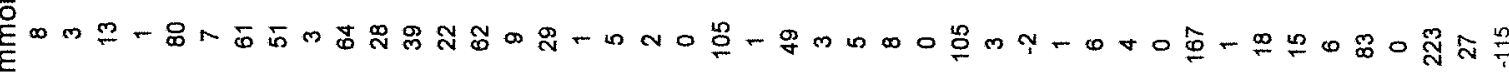

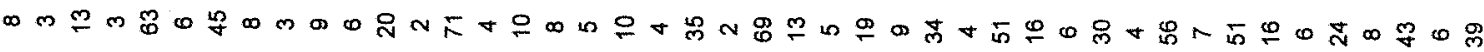

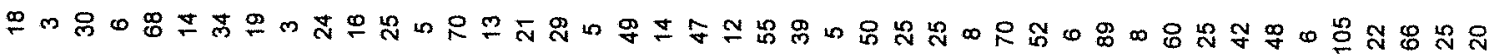
NMnN

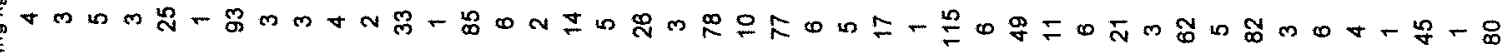

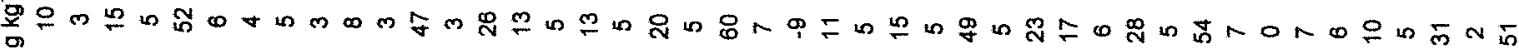

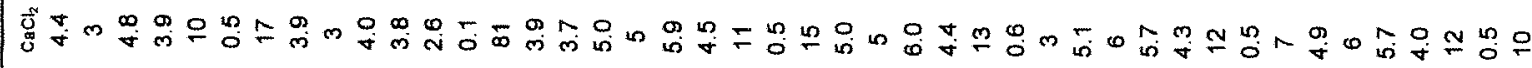

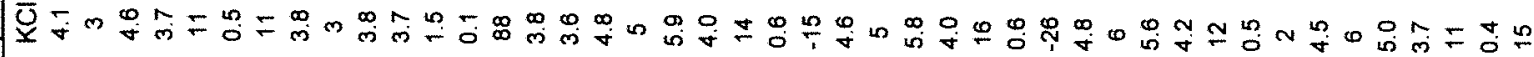

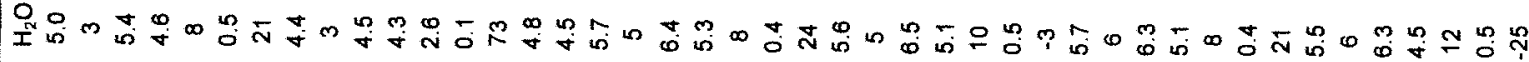

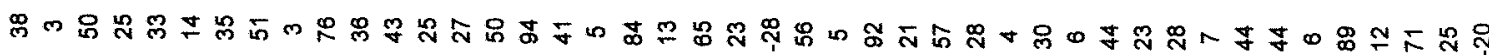

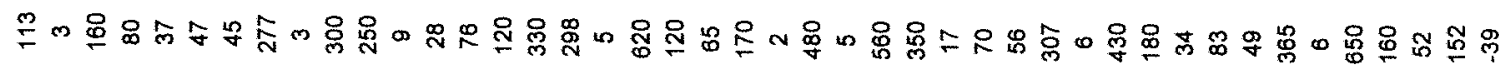
홍

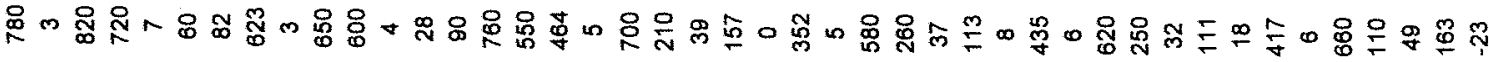

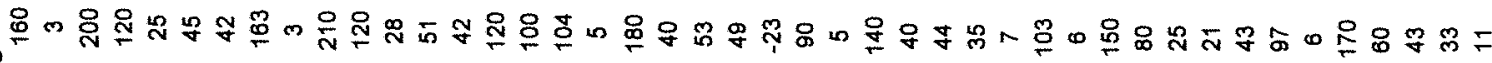

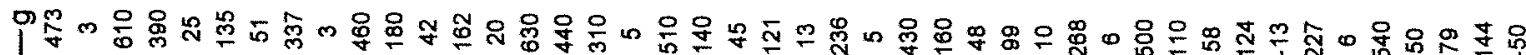

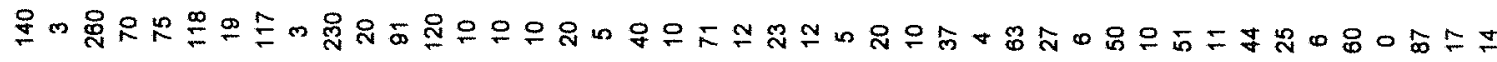

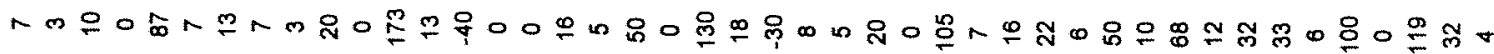

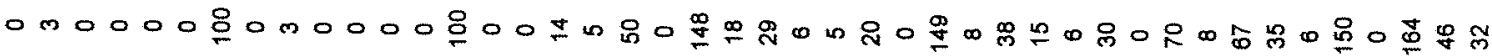

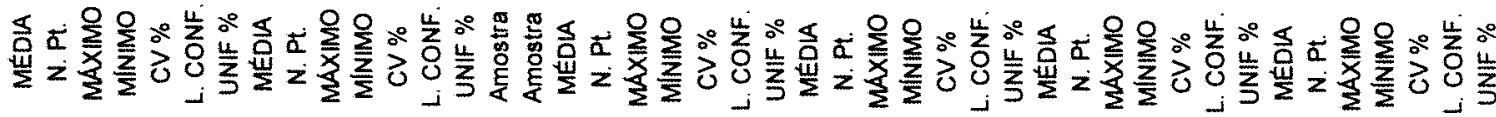

$\infty$

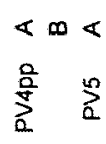

$\Phi$ 吉 竞

$\infty$ 


\begin{tabular}{|c|c|c|c|c|c|c|c|c|c|c|c|}
\hline & & & & & & & & & & & 84 \\
\hline$\stackrel{m}{=}$ & $\begin{array}{l}\infty \\
\stackrel{\sigma}{\circ}\end{array}$ & $\begin{array}{l}\infty \\
\mathbb{N}\end{array}$ & $\begin{array}{l}\text { 足 } \\
\stackrel{\sigma}{+}\end{array}$ & $\underset{0}{0}$ & $\stackrel{\stackrel{\leftrightarrow}{\mathbb{Z}}}{\underset{\forall}{*}}$ & $\stackrel{\mathscr{N}}{\underset{\sim}{~}}$ & 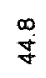 & $\stackrel{\mathscr{N}}{\mathrm{i}}$ & $\begin{array}{l}\stackrel{8}{*} \\
\dot{\nabla}\end{array}$ & $\stackrel{+}{g}$ & $\stackrel{N}{\sim}$ \\
\hline$\sum$ & $\underset{j}{+}$ & $\stackrel{\circ}{\stackrel{9}{m}}$ & $\hat{i}$ & $\begin{array}{l}0 \\
\stackrel{0}{2}\end{array}$ & 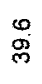 & 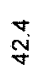 & $\hat{\circ}$ & $\stackrel{\circ}{\circ}$ & 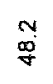 & $\stackrel{\sim}{\stackrel{N}{v}}$ & ه్ \\
\hline$\sum$ & $\begin{array}{l}0 \\
\text { go } \\
\text { go }\end{array}$ & $\stackrel{0}{\stackrel{N}{N}}$ & : & $\begin{array}{l}10 \\
0\end{array}$ & $\begin{array}{l}0 \\
\stackrel{0}{0}\end{array}$ & 幽 & $\begin{array}{c}0 \\
\stackrel{0}{\sigma}\end{array}$ & gi & ஸ્ં & 品 & $\hat{i}$ \\
\hline
\end{tabular}

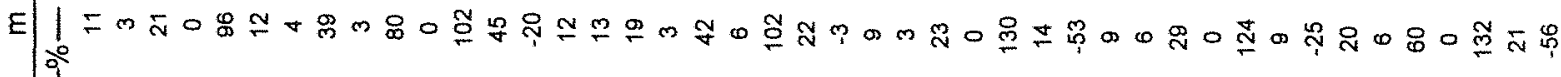

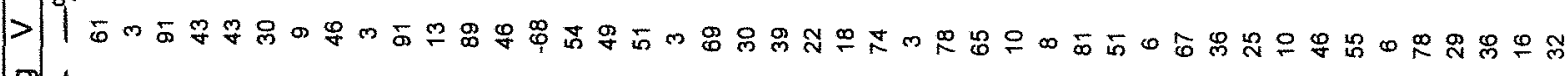

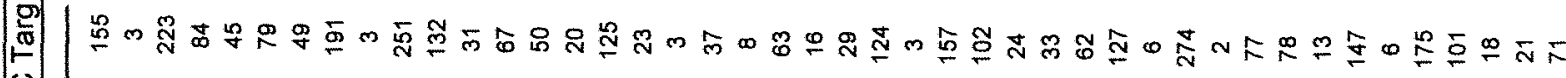

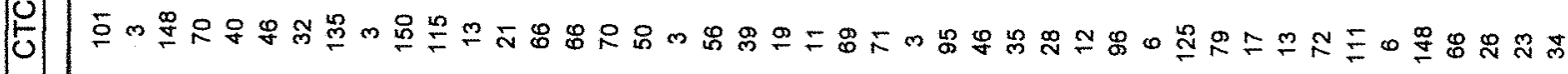

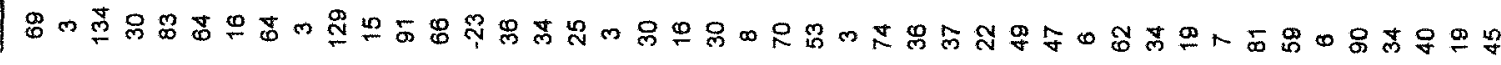

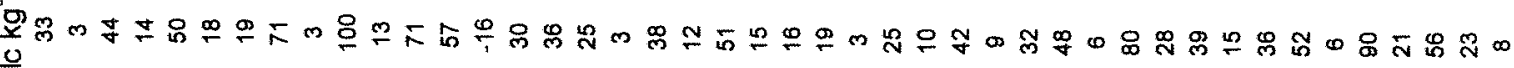

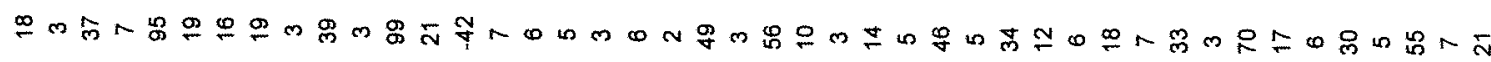

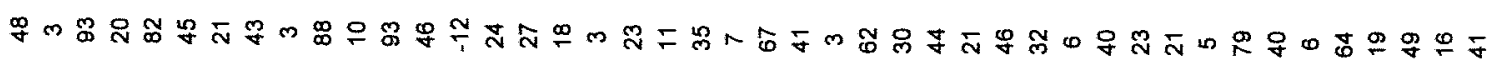
mmand-Rnd

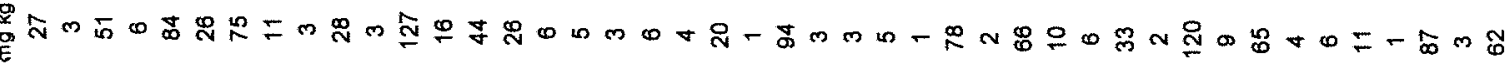

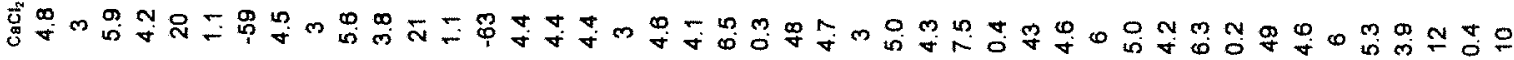

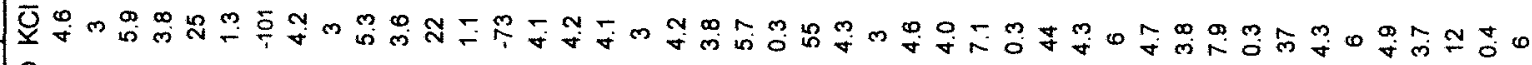

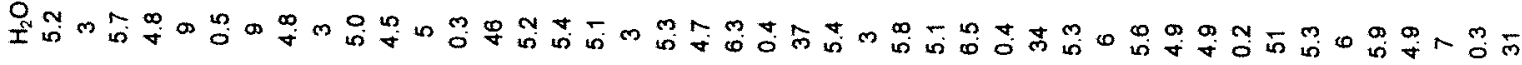

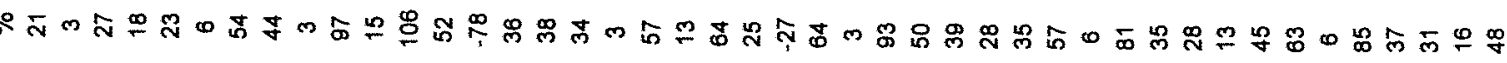

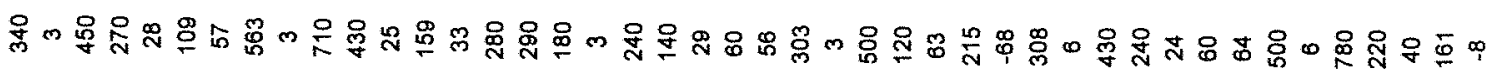

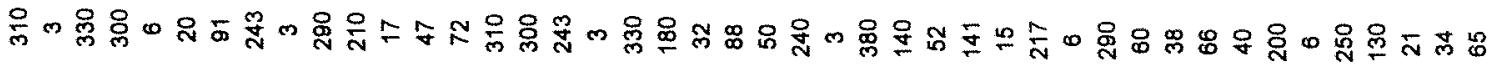

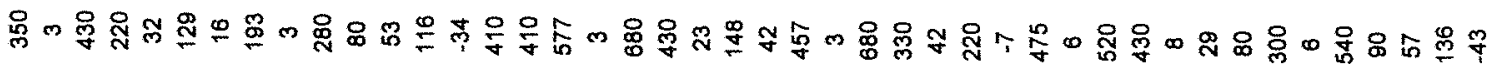

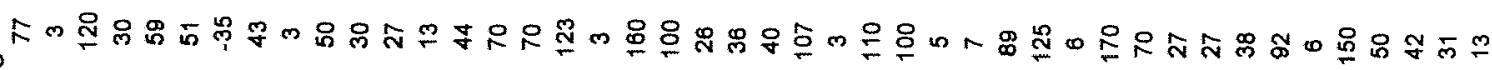

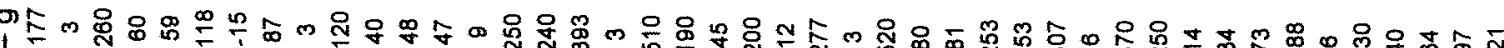

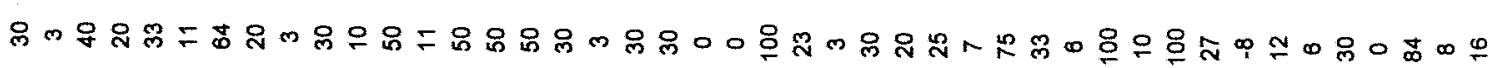

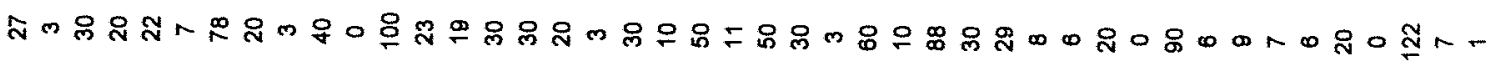

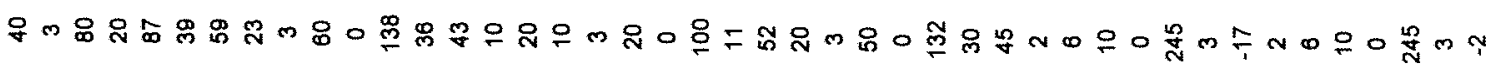

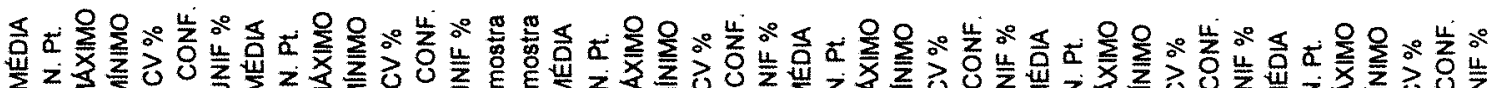

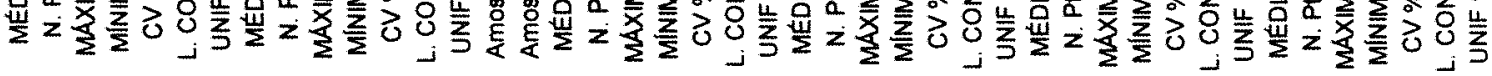
$\varangle$ $\mathbf{m}$ $<\infty<$
응 5

$\infty$ $\frac{9}{2}$ $\infty$ 


\begin{tabular}{|c|c|c|c|c|}
\hline$\stackrel{m}{\Sigma} 1$ & 菺 $\stackrel{\circ}{\stackrel{m}{\circ}}$ & $\stackrel{\infty}{i}$ & $\stackrel{4}{\square}$ & $\begin{array}{l}0 \\
\stackrel{*}{*}\end{array}$ \\
\hline$\stackrel{N}{\geq}$ & 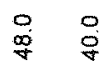 & $\ddot{\circ}$ & 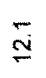 & $\begin{array}{l}\infty \\
0 \\
0 \\
0\end{array}$ \\
\hline$\sum$ & $\begin{array}{ll}3 & 0 \\
8 & 8\end{array}$ & $\overline{\widetilde{d}}$ & 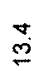 & ָָ \\
\hline
\end{tabular}

E| | I N N N $>$ |

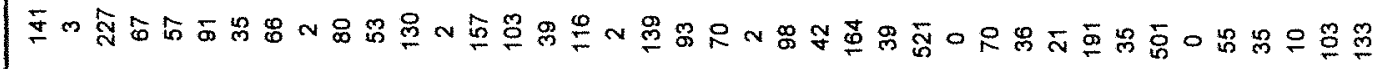

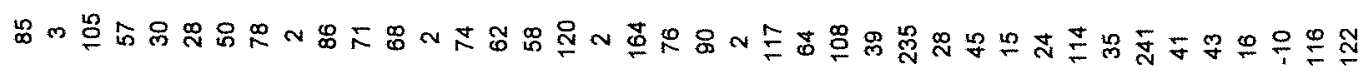

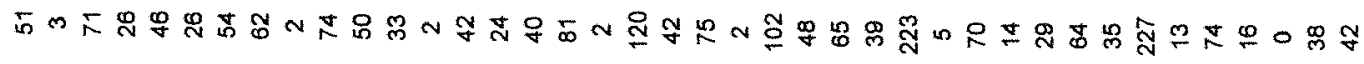

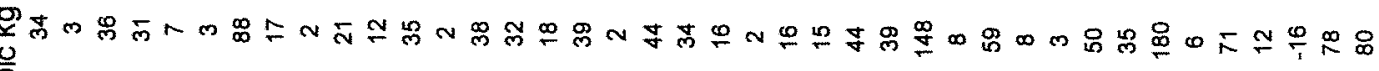

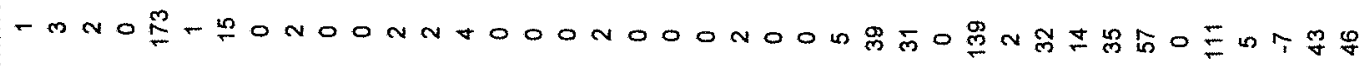
Nㅐㅇㅠ

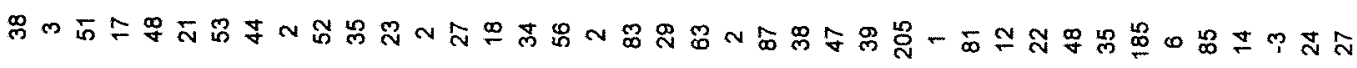
Nmm密

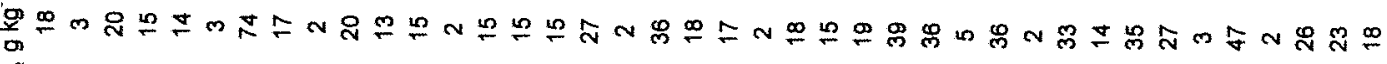

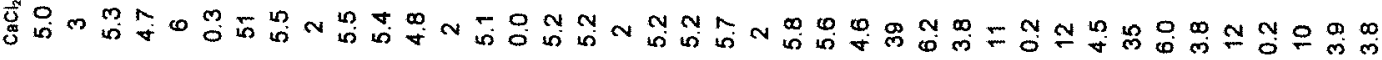

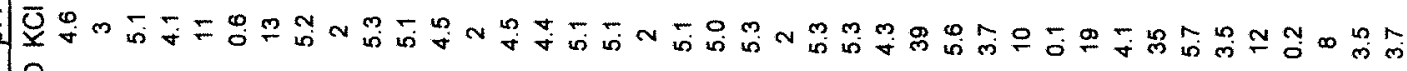

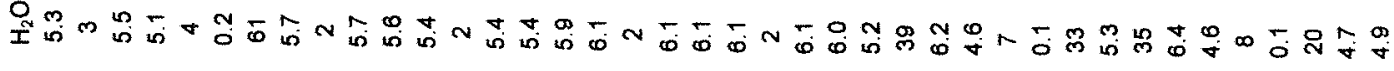
욤ำ

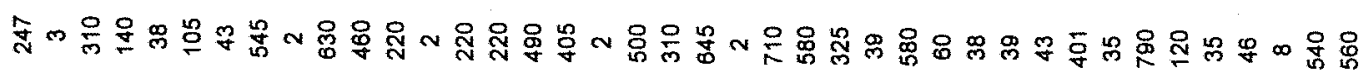

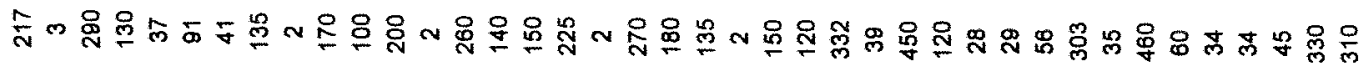

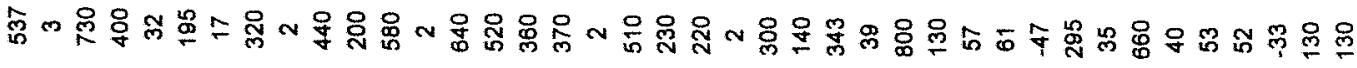

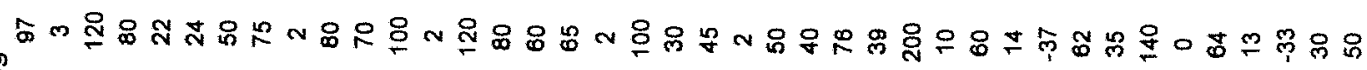
品

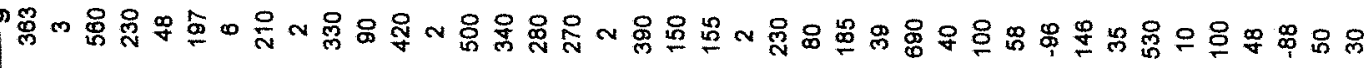

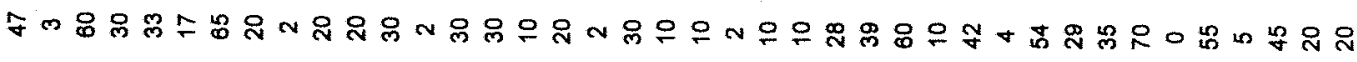

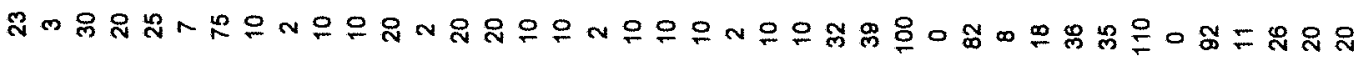

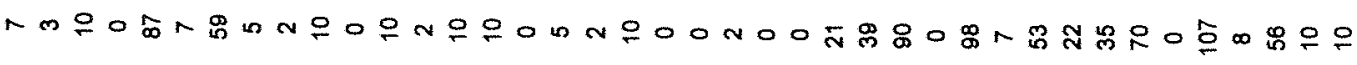

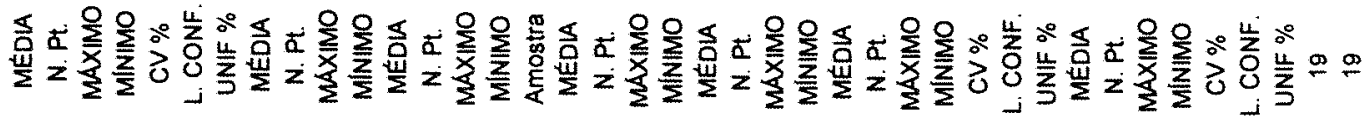
$\mathbf{m}$

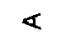
$\infty<$

$\infty$ $\varangle$ o $<0$ 嵓 $\underset{\leftarrow}{w}$ 咅 $\Xi$ 


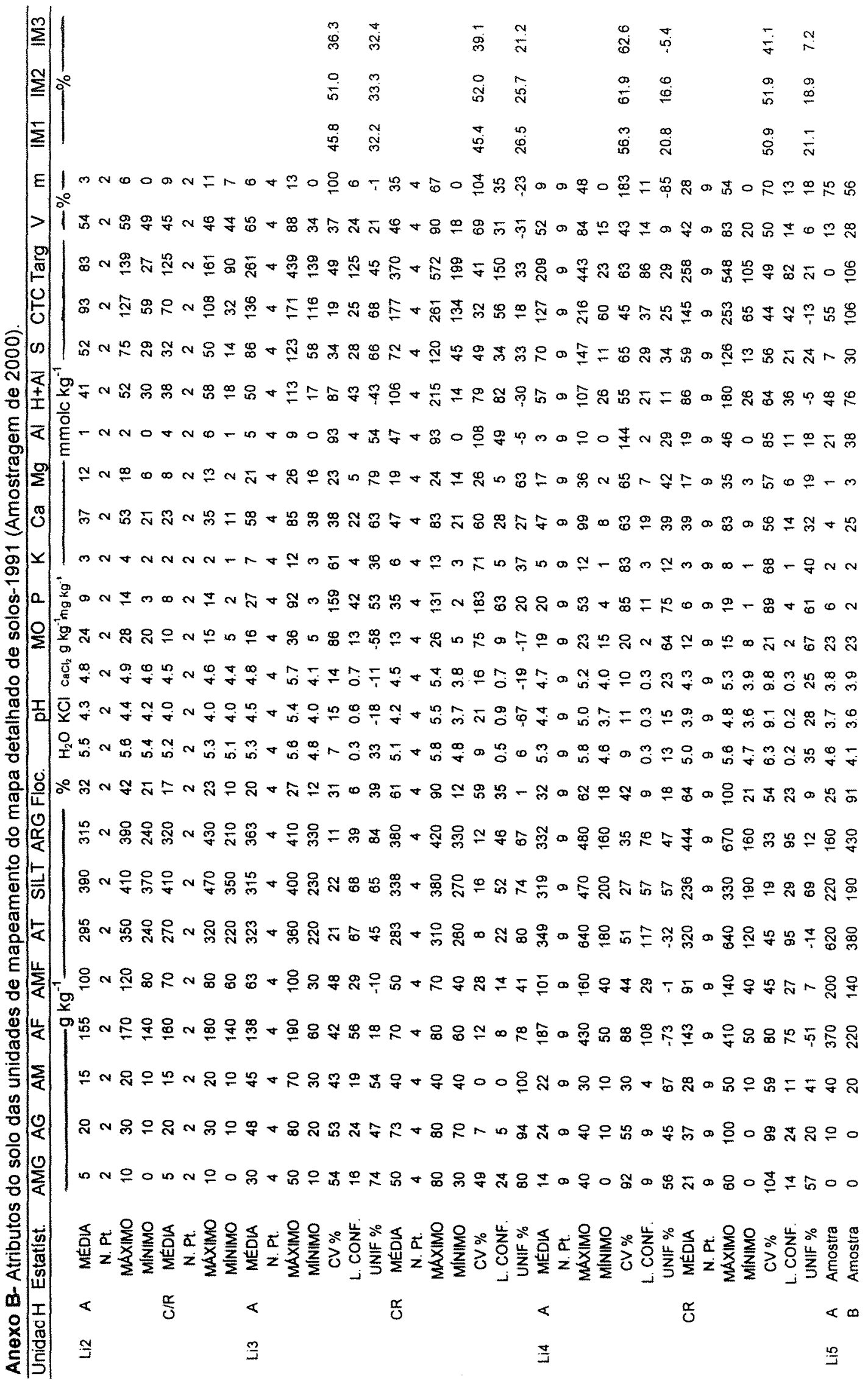




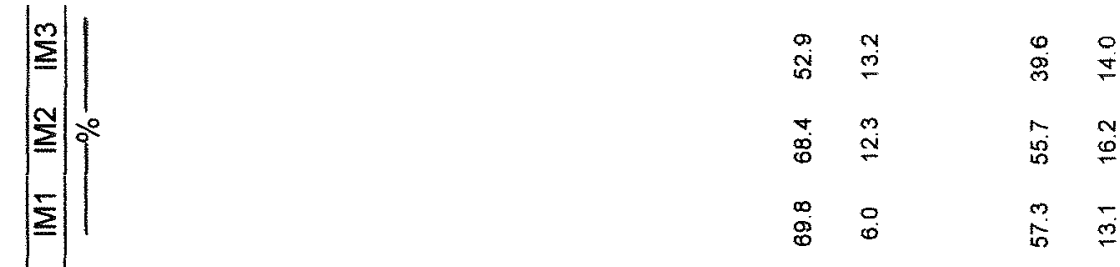

E $\mid \frac{0}{0}$ 员N $>\mid$ | 解| 总

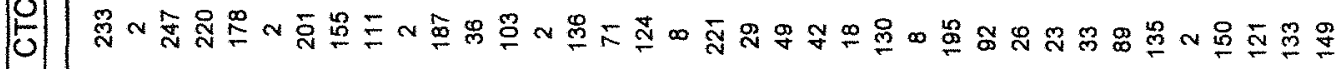

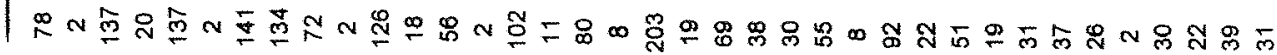

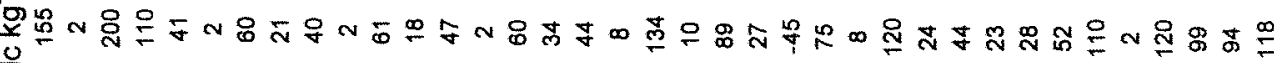

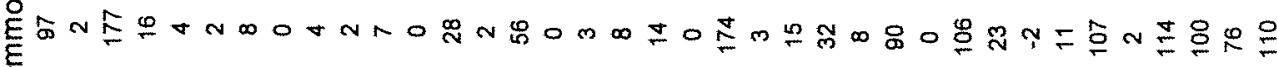
ลูก赵 ธง on

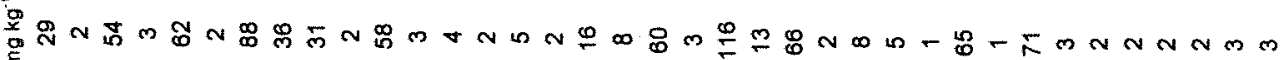
要Nำ

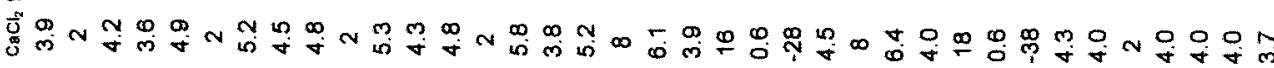
I

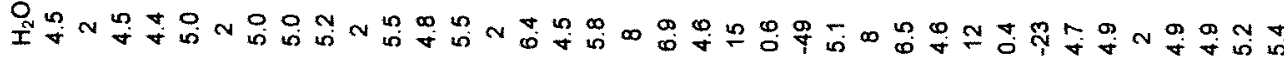

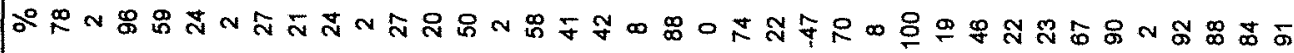

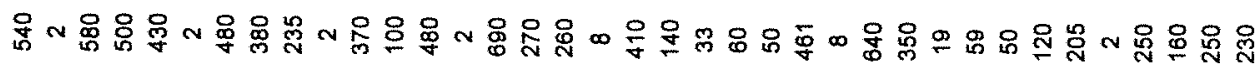

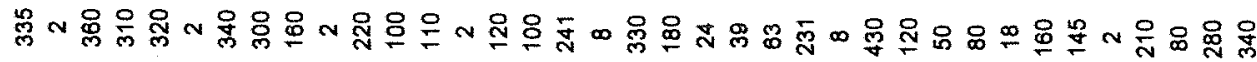

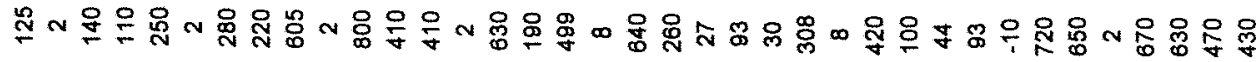
斤

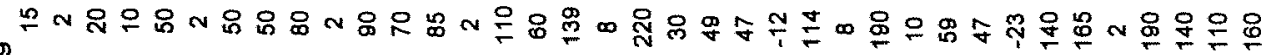
9

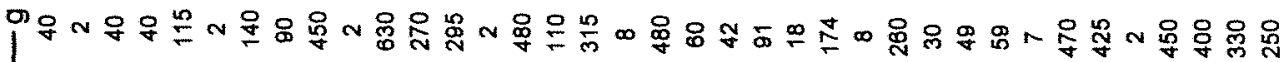

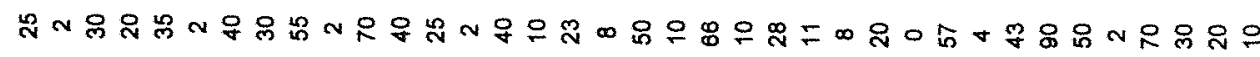

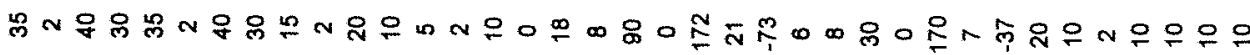

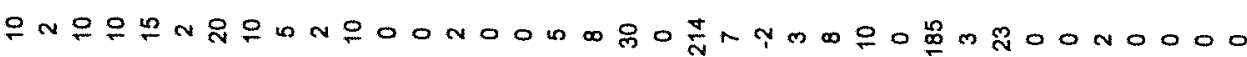

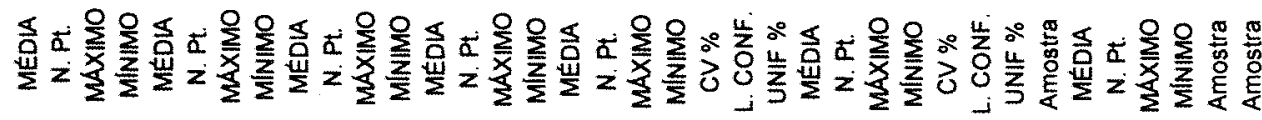
$<$ $\cong$ $₫ \quad \infty$ $<$

$m$

$\begin{array}{ll}<\infty & <\frac{U}{0} \\ \text { ก } & 8\end{array}$




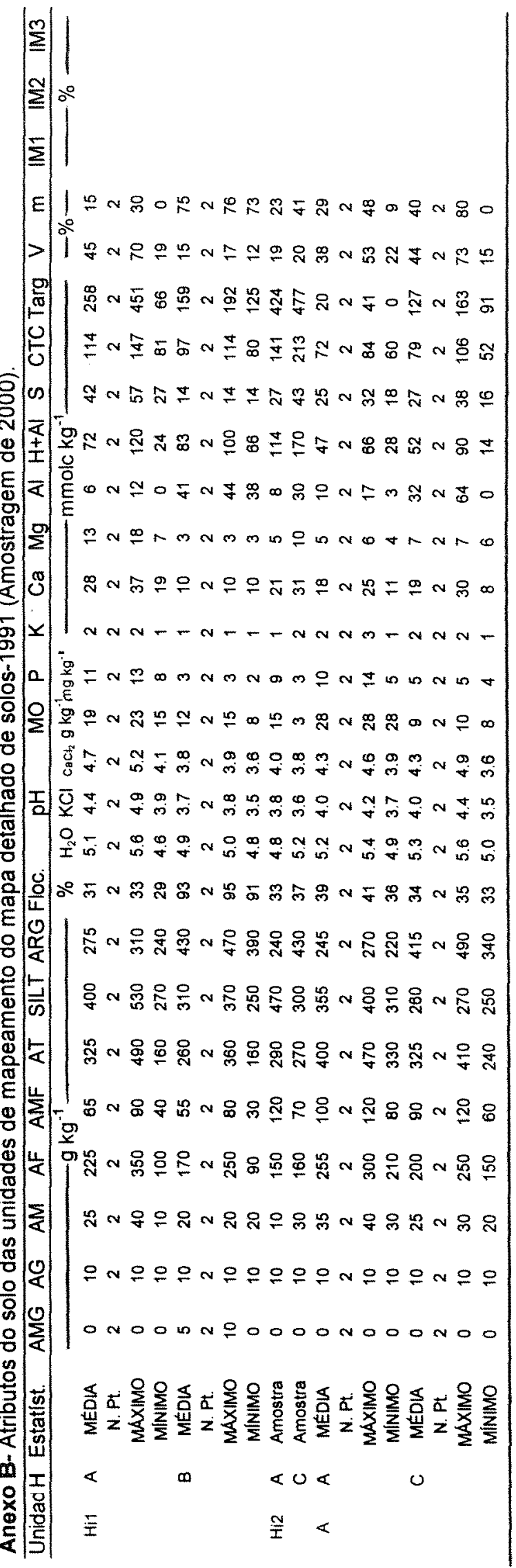




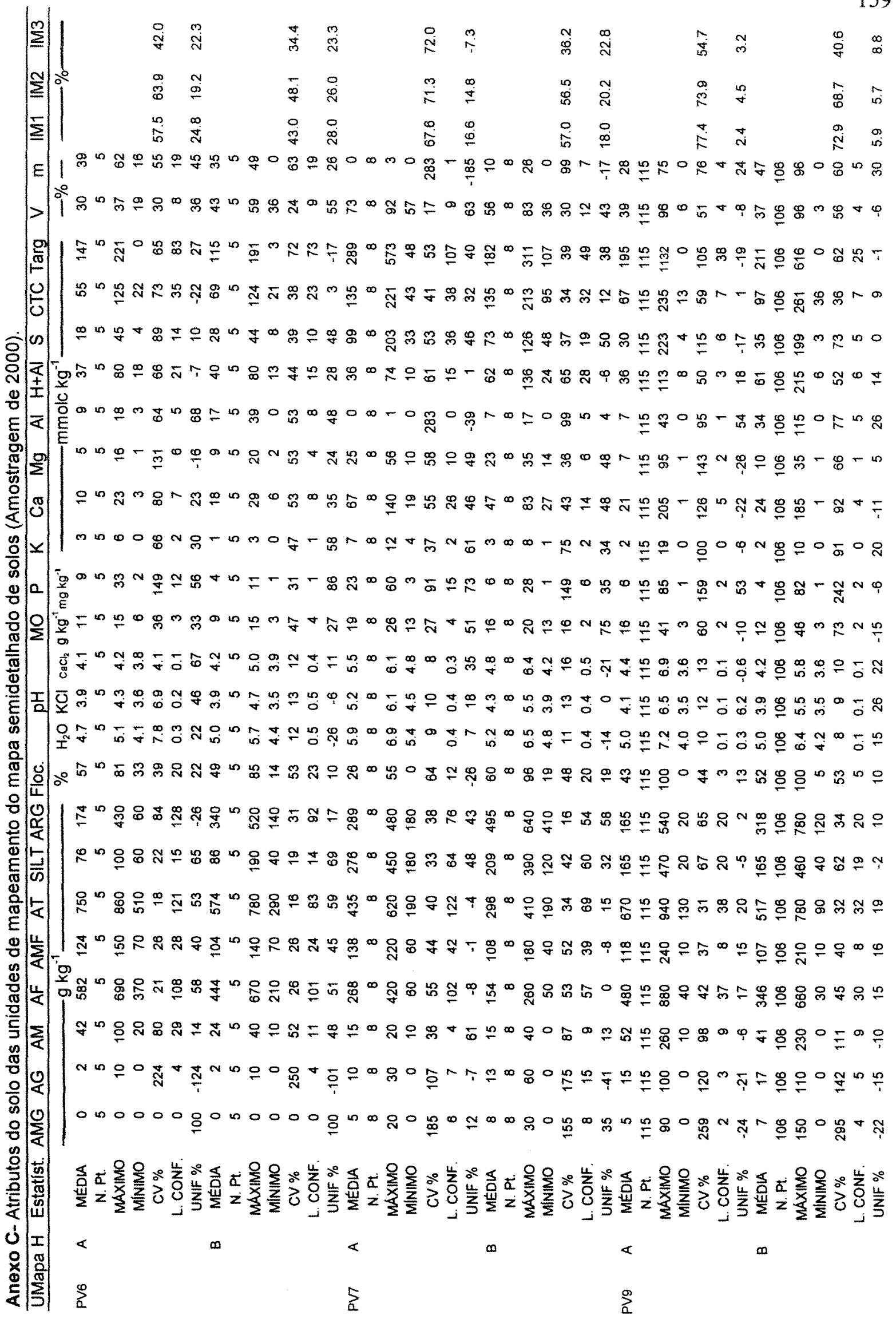




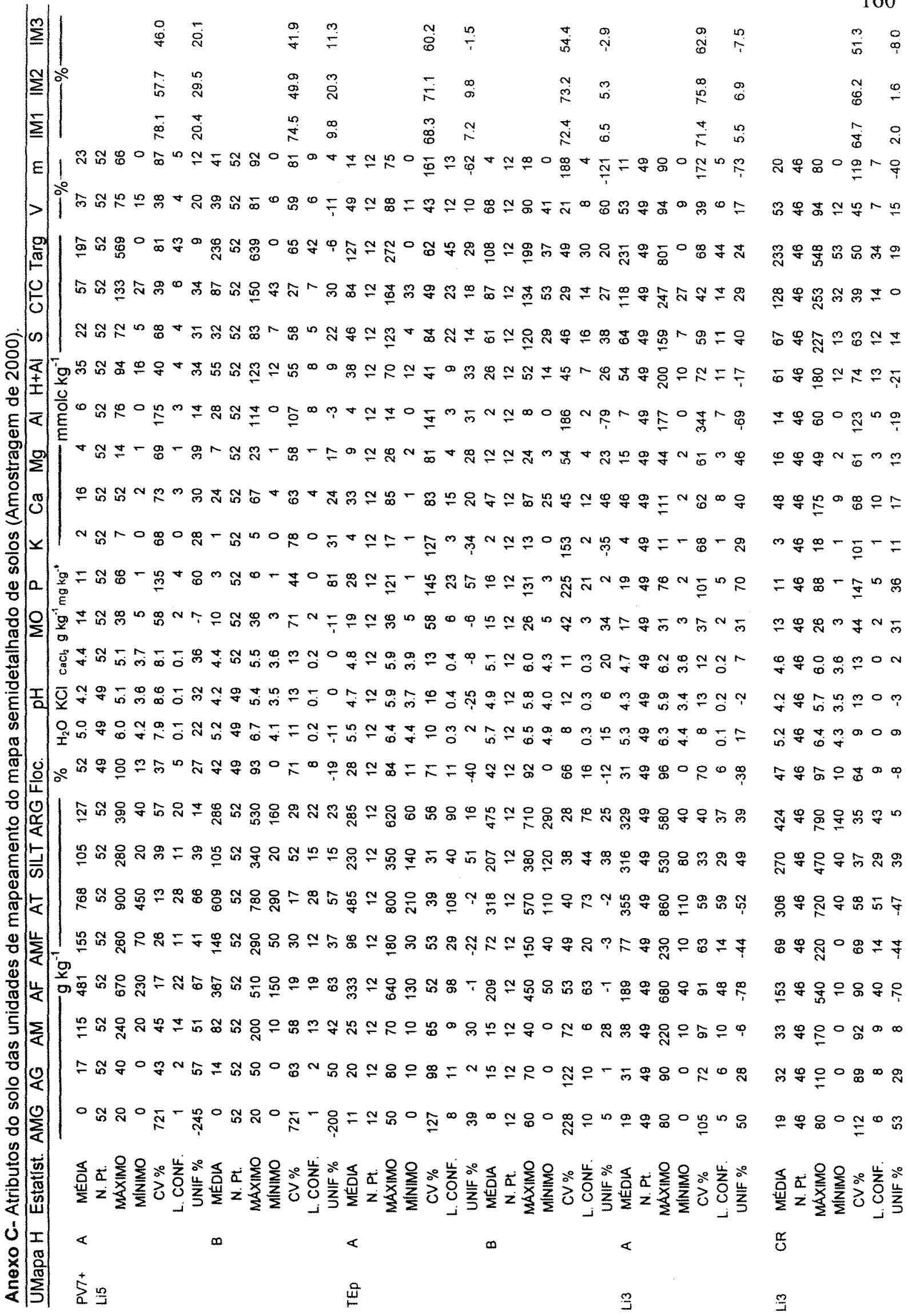




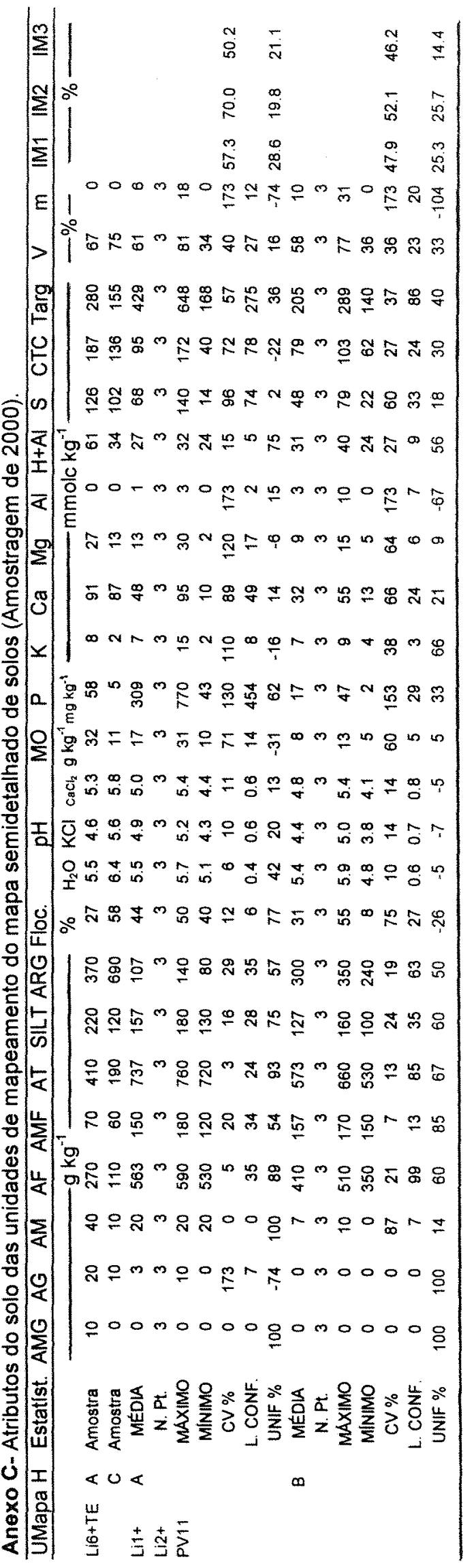




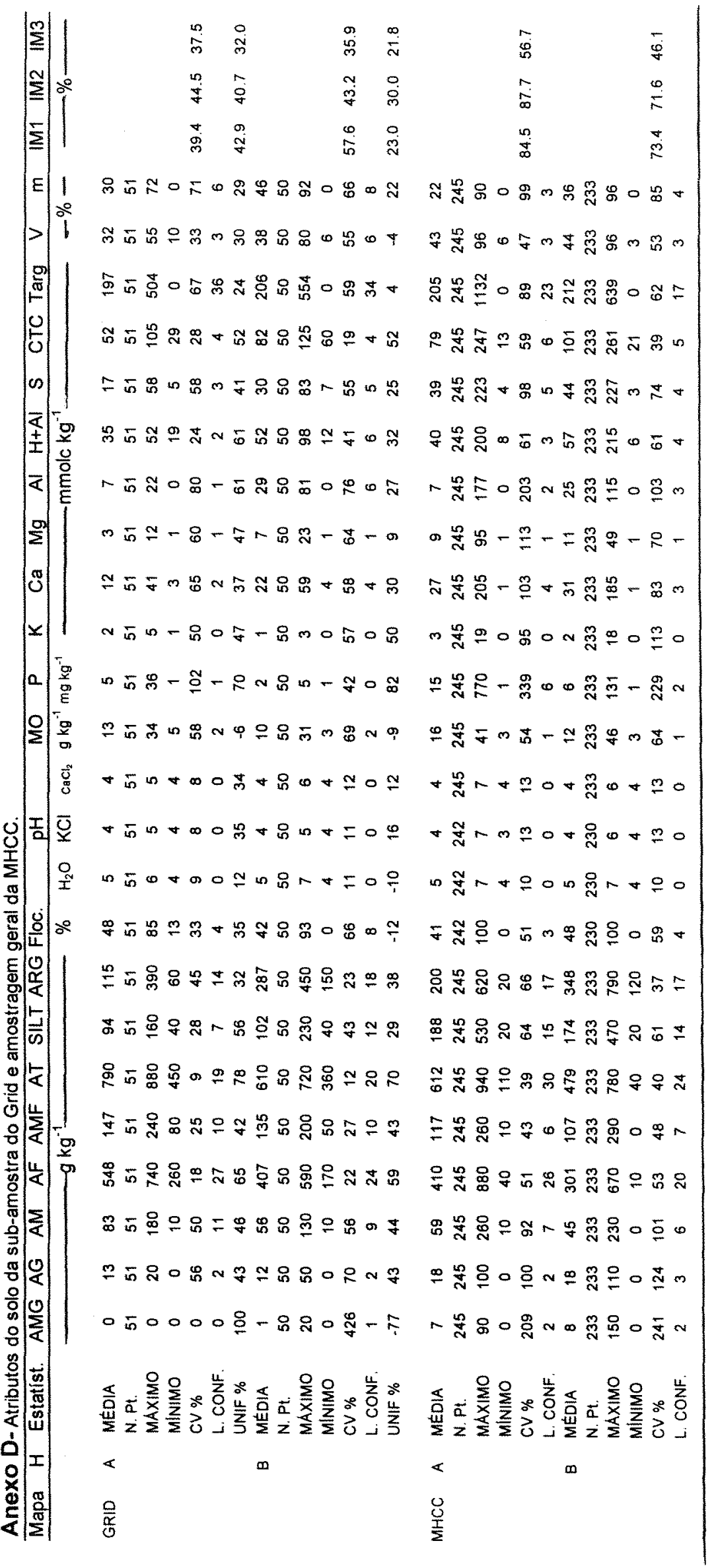


ANEXO E- Correlação entre as classes de solos ao nível de subgrupos do Sistema Brasileiro de Classificação de Solos (Embrapa, 1999) e classes da antiga classificação (Embrapa, 1988)

Subgrupos do SBCS (Embrapa, 1999)
ALISSOLOS CRÔMICOS Argilúvicos
abrúpticos
ALISSOLOS CRÔMICOS Argilúvicos
abrúpticos arênicos
abrúpticos arênicos

ALISSOLOS CRÔMICOS Argilúvicos abrúpticos lépticos

ARGISSOLOS AMARELOS Álicos epiáquicos

ARGISSOLOS VERMELHO-AMARELOS Alumínicos abrúpticos

ARGISSOLOS VERMELHO-AMARELOS Alumínicos abrúpticos arênicos

ARGISSOLOS VERMELHO-AMARELOS Alumínicos abrúpticos lépticos

ARGISSOLOS VERMELHO-AMARELOS

Distróficos abrúpticos arênicos

ARGISSOLOS VERMELHO-AMARELOS

Distróficos abrúpticos lépticos

ARGISSOLOS VERMELHO-AMARELOS

Distróficos Ta abrúpticos

ARGISSOLOS VERMELHO-AMARELOS

Eutróficos abrúpticos

ARGISSOLOS VERMELHO-AMARELOS

Eutróficos abrúpticos arênicos

ARGISSOLOS VERMELHO-AMARELOS

Eutróficos abrúpticos lépticos

ARGISSOLOS VERMELHOS Eutróficos típicos

CAMBISSOLOS HÁPLICOS Ta

Aluminicos lépticos

CAMBISSOLOS HÁPLICOS Ta Eutróficos lépticos

CAMBISSOLOS HÁPLICOS Ta Eutróficos típicos

CAMBISSOLOS HÁPLICOS Tb eutróficos lépticos
Classes de solos (Embrapa, 1988)

Podzólico Vermelho-Amarelo Ta álico Abrupto

Podzólico Vermelho-Amarelo Ta álico Abrupto fase arênico

Podzólico Vermelho-Amarelo Ta álico Abrupto fase pouco profundo

Podzólico Vermelho-Amarelo $\mathrm{Tb}$ álico gleico

Podzólico Vermelho-Amarelo $\mathrm{Tb}$ álico Abrupto

Podzólico Vermelho-Amarelo $\mathrm{Tb}$ álico Abrupto fase arênico

Podzólico Vermelho-Amarelo $\mathrm{Tb}$ álico Abrupto fase pouco profundo

Podzólico Vermelho-Amarelo $\mathrm{Tb}$

Distrófico Abrupto fase arênico

Podzólico Vermelho-Amarelo $\mathrm{Tb}$

Distrófico Abrupto fase pouco profundo

Podzólico Vermelho-Amarelo Ta

Distrófico Abrupto

Podzólico Vermelho-Amarelo $\mathrm{Tb}$

Eutrófico Abrupto

Podzólico Vermelho-Amarelo $\mathrm{Tb}$

Eutrófico Abrupto fase arênico

Podzólico Vermelho-Amarelo $\mathrm{Tb}$

Eutrófico Abrupto fase pouco profundo

Podzólico Vermelho-Escuro Tb Eutrófico

Cambissolo Ta álico

Cambissolo Ta Eutrófico

Cambissolo Ta Eutrófico

Cambissolo Tb Eutrófico 
ANEXO E- Continuação

\begin{tabular}{|c|c|}
\hline $\begin{array}{l}\text { CAMBISSOLOS HÁPLICOS Tb Eutróficos } \\
\text { típicos }\end{array}$ & Cambissolo Tb Eutrófico \\
\hline $\begin{array}{l}\text { CHERNOSSOLOS ARGILÚVICOS Órticos } \\
\text { típicos }\end{array}$ & $\begin{array}{l}\text { Terra Roxa Estruturada podzólica } \\
\text { eutrófica A chernozêmico }\end{array}$ \\
\hline GLEISSOLOS HÁPLICOS Indiscriminados & Glei Pouco Húmico indiscriminados \\
\hline LUVISSOLOS CRÔMICOS Pálicos típicos & Vermelho-Amarelo \\
\hline $\begin{array}{l}\text { LUVISSOLOS CRÔMICOS Pálicos } \\
\text { arênicos abrúpticos }\end{array}$ & $\begin{array}{l}\text { Podzólico Vermelho-Amarelo } \\
\text { eutrófico abrupto fase arênico }\end{array}$ \\
\hline $\begin{array}{l}\text { LUVISSOLOS CRÔMICOS Órticos } \\
\text { abrúpticos }\end{array}$ & $\begin{array}{l}\text { Podzólico Vermelho-Amarelo } \\
\text { eutrófico abrupto fase pouco profundo }\end{array}$ \\
\hline $\begin{array}{l}\text { NITOSSOLOS VERMELHOS Eutróficos } \\
\text { argissólicos }\end{array}$ & $\begin{array}{l}\text { Terra Roxa Estruturada podzólica } \\
\text { eutrófica }\end{array}$ \\
\hline $\begin{array}{l}\text { NITOSSOLOS VERMELHOS Eutróficos } \\
\text { típicos }\end{array}$ & Terra Roxa Estruturada eutrófica \\
\hline NEOSSOLOS FLÚVICOS Tb Eutróficos & Solos Aluviais $\mathrm{Tb}$ eutróficos \\
\hline NEOSSOLOS LITÓLICOS álicos típicos & Solos Litólicos álicos \\
\hline $\begin{array}{l}\text { NEOSSOLOS LITÓLICOS Eutróficos } \\
\text { típicos }\end{array}$ & Solos Litólicos eutróficos \\
\hline $\begin{array}{l}\text { NEOSSOLOS LITÓLICOS Eutróficos } \\
\text { chernossólicos }\end{array}$ & $\begin{array}{l}\text { Solos Litólicos eutróficos } \\
\text { chernozêmico }\end{array}$ \\
\hline $\begin{array}{l}\text { NEOSSOLOS LITÓLICOS Distróficos } \\
\text { típicos }\end{array}$ & Solos Litólicos distróficos \\
\hline NEOSSOLOS INDIFERENCIADOS & Sedimentos Coluvionais \\
\hline
\end{tabular}




\section{REFERÊNCIAS BIBLIOGRÁFICAS}

SADAMS, J.A.; WILDE, R.H. Comparison of the variability in a soil taxonomic unit with that of the associated soil mapping unit. Australian Journal of Soil Reseach, v.18, n.3, p. 285-297, Aug. 1980.

AGBU, P. A.; FEHRENBACHER, D.; JANSEN, I. J. Soil property relationships with SPOT satellite digital data in east central Illinois. Soil Science Society of American Journal, Madison, v. 54, p.807-812, 1990.

ANANKO, T. V.; SOKOLOV, I. A.; KONYUSHKOV, D. E.; GRADUSOV, B.P. A system of soil maps: Experience in application of a polycomponent basic classification of soils for mapping purposes. Eurasian Soil Science, v.31, n.1: p.561-573, 1998.

ARNOLD, R.W. Estimating accuracy of soil mapas. Paper for presentation at Soil Resource Inventory Workshop. Ithaca, AID/Cornell University, 1977. 8p. (mimeografado)

AZOLIN, M.A.D.; KLAMT, E.; SANTOS, M.C.L. Relações solos superficies geomórficas e material de origem a oeste da depressão central e campanha no Rio Grande do Sul. In: Congresso Brasileiro de Ciência do Solo. Campinas-SP, Sociedade Brasileira de Ciência do Solo, v.2, p. 345-350, 1978.

BALDWIN, M.; KELLOG, C.E.; THORP, J. Soil classification. In: Soils and men: Yearbook of Agriculture, 1938. Washington, U.S. Dept. Agric., 1938. p. 979-1001.

BASHER, R. Is pedology dead and buried? Australian Journal of Soil Research, v.35, n.5: p.979-994, 1997. 
BECKETT, P. H. T.; BURROUGH, P. A. The relation between cost and utility in soil survey: IV. Comparison of the utilities of soil maps produced by different survey procedures and different scales. Journal of Soil Science, v. 22, n. 4, p.466-480, 1971.

BECKETT, P. H. T.; WEBSTER, R. Soil Variability: A review. Soils and Fertilizers, v.34, n.1,1-15. 1971.

BERG, M.V.D.; KLAMT, E. Variabilidade espacial de caraterísticas de solos na região do planalto médio, RS: I. Análise da variância pôr amostragem aninhada. Revista Brasileira de Ciência do Solo. v. 21, n. 3, p. 393-399, jul./set. 1997.

BERG, M.V.D.; KLAMT, E. Variabilidade espacial de caraterísticas de solos na região do planalto médio, RS: II. Análise da semivariância e da variância. Revista Brasileira de Ciência do Solo. v. 21, n. 3, p. 401-408, jul./set. 1997.

BERG, M.V.D.; LEPSCH, I.F.; SAKAI, E. Solos das planícies aluviais do vale do rio Ribeira do Iguape, SP: I. Padrões de distribuição. Revista Brasileira de Ciência do Solo, v.11, n. 2, p. 305-313, jan./abr. 1987.

BHERING, S. B. Sistema de informação de solos: diretrizes para o desenvolvimento. São Paulo, 1995. 167p. Dissertação (Mestrado) - Escola Politécnica, Universidade de São Paulo.

BIE, S. W.; BECKETT, P. H. T. Quality control in soil survey. I: The choiceof mapping unit. Journal of Soil Science, v.22, n.1, p.32-49, 1971.

BIE, S. W.; BECKETT, P. H. T. Comparison of 4 independent soil surveys by air-photo interpretation, Paphos area (Cyprus). Photogrammetria, v.29, n.6: p.189-202, 1973.

BOUMA, J. Using soil survey data for quantitative land evaluation. In: STEWART, B.A., ed. Advances in Soil Science , v.9, p.177-213, 1989.

BOUMA, J. Sustainable land use as a future focus for pedology. Soil Science Scince Society of American Journal, v.58, p.645-646, 1994. 
BRAGA, L.P.; FUKS, S. D. Analysis and classification of soil properties by geostatistical and fuzzy methods. In: International Forum to Geostatistics. Proceedings Canada. 1993.

BREIMER, F.R.; KEKEN, A.J. van; REULER, H. van. Guidelines for soil survey and land evaluation in ecological research. Paris: UNESCO, 1986. 125p. (MAB Technical Notes, 17).

BRINKMANN, R. Ferrolysis a hidromorphic soil process. Geoderma, v.3, n.2, p.199206, mar, 1970.

BRUBAKER, S.C.; HALLMARK, C.T. A comparison of statistical methods for evaluating map unit composition. In: MAUSBACH, M.J.; WILDING, L.P. Spatial Variabilities of Soils and Landforms. p. 73-88. SSSA Special Publication Number 28. Soil Science Scince Society of American: Madison, WI). 1991

BURROUGH, P.A. Multiscale sources of spatial variation in soil. II: A non-Brownian fractal model and its application in soil survey. Journal of Soil Science, v.34, n.3, p.599-620, 1983.

BURROUGH,.P.A. Principles of geographical information systema for land resources assessment. Oxford: Claredon Press, 1986. 193p.

BURROUGH, P. A. Fuzzy mathematical methods for soil survey and land evaluation. Journal of Soil Science, v.40, p.472-492, 1989.

BURROUGH, P. A. Sampling schemes for quantifying map unit composition. In: MAUSBACH, M.J.; WILDING, L.P. Spatial Variabilities of Soils and Landforms. p.89-126. SSSA Special Publication Number 28. Soil Science Scince Society of American: Madison, WI). 1991

BURROUGH, P.A. The Technological Paradox in Soil Survey: New Methods and Techniques of Data Capture and Handling. ITC Journal, 1993-1, p.15-23. 1993.

BURROUGH, P. A.; BECKETT, P. H. T.; JARVIS, M. G. The relation between cost and utility in soil survey (I-III). Journal of Soil Science, v.22, n.3, p.359-394, 1971. 
CAMARGO, O.A.; MONIZ, A.C. JORGE, J.A. \& VALADARES, J.M.A.S. Métodos de análise química, mineralógica e física de solos do Instituto Agronômico do Estado de São Paulo. Ból. Tec., 106. Campinas, 94p. 1986.

CHAGAS, C.S.; CURI, N.; DUARTE, M.N.; MOTTA, P.E.F.; LIMA, J.M. Orientação das camadas de rochas metapilíticas pobres na gênese de Latossolos sob cerrado. Pesquisa Agropecuária Brasileira, v. 32, n. 5, p. 539-548. maio. 1997.

CIHLAR, J.; PROTZ, R. Surface characteristics of mapping units related to aerial imaging of soils. Canadian Journal of Soil Science, v.53, p.249-257, 1973.

CLINE, M.G. Principles of soil sampling. Soil Science, v.58, p.275-288. 1944.

CLINE, M.G. Basic principles of soil classification. Soil Science, v.67, p.81-91. 1949.

COELHO, R.M.; LEPSCH, I.F.; MENK, J.R.F. Relações solo-relevo em uma encosta com transição arenito-basalto em Jaú (SP). Revista Brasileira de Ciência do Solo, v.18, n.1, p. 125-137, jan./abr. 1994.

COWIE, J.D. Soil from andesitic tephra and their variability, Tongatapu, kingdom of Tonga. Australian Journal of Soil Research, v.18, n.3, p. 273-284, Aug. 1980.

De BIE, C.A.; BEEK, K.J.; DRIESSEN, P.M.; ZINCK, J.A. Em direção a operacionalização dos solos para um manejo sustentável das terras. In: ALVAREZ V., V. H.; FONTES, L.E.F. \& FONTES, M.P.F. Ed. O solo nos grandes domínios morfoclimáticos do Brasil e o desenvolvimento sustentado. Viçosa, MG. SBCS; UFV, DPS, 1996. p.335-352.

DEMATTÊ, J.L.I.; MONIZ, A.C.; PESSOTI, J.E.S. Solos originados de sedimentos do grupo geológico Estrada Nova, Município de Piracicaba, I. Análise mineralógica quantitativa da fração argila. Revista Brasileira de Ciência do Solo, v.1, n.1, p. 4347, jan./abr. 1977.

DEMATTÊ, J.L.I.; VIDAL-TORRADO, P.; SPAROVEK, G. Influência da drenagem na morfogênese de solos desenvolvidos de rochas básicas no Município de PiracicabaSP. Revista Brasileira de Ciência do Solo, v.16, n.2, p. 241-247, maio/ago. 1992. 
DENT, D.; YOUNG, A. Soil survey and land evaluation. London: Allen \& Unwin, 1981. 278p.

DIEPEN, C. A., KEULEN, H., WOLF, J. BERKHOUT, A.A. Land Evaluation: from intuition to quantification. Advances in Soil Science, New York, v.15: p.140-204, 1991.

DREES, L.R.; WILDING, L.P. Elemental variability within a sampling unit. Soil Science Scince Society of American Proceedings, v.37, n.1, p.82-87, Jan./Feb., 1973.

DUMANSKI, J. Strategies and opportunities for soil survey information and research. ITC Journal, 1993-1, p.36-41, 1993.

EASTMAN, J. R. IDRISI - User's Guide. Worcester: Clark University. 1997.

EMBRAPA, Centro Nacional de Pesquisa de Solos (Rio de Janeiro, RJ). Procedimentos normativos de levantamentos pedológicos / Santos, H.G. et al.. - Brasília: EMBRAPA - SPI, 1995. 101p.

EMBRAPA, Centro Nacional de Pesquisa de Solos (Rio de Janeiro, RJ). Sistema brasileiro de classificação de solos. - Brasília: Embrapa Produção de Informação; Rio de Janeiro: Embrapa Solos, 1999. 412p.

EMBRAPA, Serviço Nacional de Levantamento e Conservação de Solo (Rio de Janeiro, RJ). Critérios para distinção de classes de solos e de fases de unidades de mapeamento; normas em uso pelo SNLCS. Rio de Janeiro, EMBRAPA, SNLCS, 1988. (Documentos SNLCS, 11).

ESTADOS UNIDOS. Department of Agriculture. Soil taxonomy: A basic system of soil classification for making and interpreting soil surveys. Washington, U.S. Govt. Printing Office, 1975. 754. (U.S. Dept. Agric. Handbook, 436)

ESTADOS UNIDOS. Department of agriculture. Soil survey division. Soil conservation service. Soil survey staff. Soil survey manual. Rev. Enlarg. Ed. Washington, 1993. 437p. (USDA. Agriculture handbook, 18). 
FAO (Roma, Italia) Soil map of the world: 1:5000.000 legend. Paris:UNESCO, 1974. v.1.

FIORIO, P. R. Cronologia do uso da terra e seu impacto no ambiente da Microbacia Hidrográfica do Córrego do Ceveiro da região de Piracicaba, SP. Piracicaba, 1998. 107p. Dissertação (Mestrado) - Escola Superior de Agricultura "Luiz de Queiroz", Universidade de São Paulo.

FOCHT, D. Influência do avaliador no resultado da classificação de terras em capacidade de uso. Piracicaba, 1998. 79p. Dissertação (Mestrado) - Escola Superior de Agricultura "Luiz de Queiroz", Universidade de São Paulo.

GOOVAERTS, P. Geostatistics in soil science: state-of-the-art and perspectives. Geoderma, v.89, p.1-45, 1999.

HARMSWORTH, G.R.; DYMOND, J.R.; McLEOD, M. Automated mapping of hilly terrain using DTMs: a New Zealand example. ITC Journal, 1995-2, p.87-94. 1995.

HOFFER, R. M. Challenges in developing and applying remote sensing to ecosystem management. In: Remote and GIS in Ecosystem Management. Ed. 5. Alaric Sample, 1994. p.25-47.

HUDSON, B.D. The soil survey as a paradigm-based science. . Soil Science Society of American Journal, v.56, p.836-841. 1992.

IBAÑES, J.J.; ZINK, J.A.; JIMÉNEZ-BALLESTA,R. ITC Journal, 1993-1, p.7-14, 1993.

INDORANTE, S. J.; McLEESE, R. L.; HAMMER, R. D.; THOMPSON, B. W.; ALEXANDER, D. L. Positioning soil surve for the $21^{\mathrm{ST}}$ Century. Journal of Soil and Water Conservation, v.51, n.1, p.21-28, Jan/Feb. 1996.

INSTITUTO DE PESQUISAS TECNOLÓGICAS. Mapa geológico do Estado de São Paulo. Escala 1:1.000.000. Divisão de Minas e Geologia Aplicada do Instituto de Pesquisas do Estado de São Paulo. São Paulo, 1981. 
JENNY, H. Factors of soil formation; a system of quantitative pedology. New York: McGraw-Hill, 1941. 281p.

KLAMT, E. Pesquisa em ciência do solo na região sul do Brasil: Diagnóstico, perspectivas e prioridades. In: ALVAREZ V., V. H.; FONTES, L.E.F. \& FONTES, M.P.F. Ed. O solo nos grandes domínios morfoclimáticos do Brasil e o desenvolvimento sustentado. Viçosa, MG:SBCS; UFV, DPS, 1996. p.411-421.

LAFFAN, M.D.; DALY, B.K.; WHITTON, J.S. Podzolized soils on Hilly and Steep Land near Tennyson Inlet, Marlborough Sounds New Zealand: Classification and relation to landform, slope and altitude. Australian Journal of Soil Research, v.24, n.2, p. 115-136, 1986.

LAGACHERIE, P.; LEGROS, J. P.; BURROUGH, P. A. A soil survey procedure using knowledge of soil pattern established on a previously mapped reference area. Geoderma, v.65, p.283-301, 1995.

LEENHARDT, D.; VOLTZ, M.; BORNAND, M. WEBSTER, R. Evaluating soil maps for prediction of soil water properties. European Journal of Soil Science, v.45, p.293-301, 1994.

LEMOS, R.C. \& SANTOS, R.D. dos. Manual de descrição e coleta de solo no campo. $3^{\underline{a}}$ ed., Campinas. Sociedade Brasileira de Ciência do Solo. 1996. 84p.

LEPSCH, I. F.; BELLINAZZI Jr., R.; BERTOLINI, D.; ESPINDOLA, C. R. Manual para levantamento utilitário do meio físico e classificação de terras no sistema de capacidade de uso. Campinas: Sociedade Brasileira de Ciência do Solo, 1991. $175 \mathrm{p}$.

LEPSCH, I. F.; BUOL, S. W.; DANIELS, R. B. Soils landscape relationships in the occidental plateau of Sao Paulo State, Brazil: I. Geomorphic surfaces and soil mapping units. Soil Science Society of American Proceedings, v.41, n.1, p.104$108,1977$. 
LiBARDI, P. L.; PREVEDEllo, C. L.; PAUletTo, E. A.; MORAES, S. O. Variabilidade espacial da umidade, textura e densidade de partículas ao longo de uma transeção. Revista Brasileira de Ciência do Solo, v.10, p.85-90, 1986.

MacEWAN, R.J. Soil quality indicator: pedological aspects. In: GREGORICH, E.G; CARTER, M.R. Soil quality for crop production and ecosystem health. Develoments in Soil Science 25, Elsevier Science, 1997. p.143-166.

MARSMAN B.A. \& GRUIJTER, J.J. de. Quality of soil maps: A comparison of soil survey methods in a sandy area. Soil Survey Papers, 15. Wageningen, The Netherlands, 1986, 102p.

McCORMACK, D.E.; WILDING, L.P., Variation of soil properties within mapping units of soils with contrasting substrata in N.W. Ohio. Soil Science Society of American Proceedings, v.33, n.4, p.587-593, 1969.

McGRAW, T. Soil test level variability in souther Minesota. Better crops, Potash \& Phosphate Institute, Norcross, v. 78, n. 4, p. 24-25, 1994.

MEENTENMEYER, V.; BOX, E.O. Scale effects in landscape stadies. In: TURNER, M.G., (Ed.) Landscape heterogeneity and disturbance. New York, Springer Verlag, 1987. p. 15-34.

MILNE, G. Some suggeted units for classification and mapping, particulary for East African soils. Berlin. Soil Research, v.4, n.3, p. 183-198, 1935.

MONIZ, A.C.; OLIVEIRA, J.B.; CURI, N. Mineralogia da fração argila de rochas sedimentares e de solos da folha de Piracicaba-SP. Revista Brasileira de Ciência do Solo, v.19, n.3, p. 375-385, set./dez. 1995.

MOORMANN, F.R. Microvariabilidad de los suelos. In: DROSDOFF, M.; AUBERT, G.; COULTER, J.K. Suelos de las regiones tropicales humedas. Buenos Aires: Marimar. 1975. 271p.

NOGUEIRA, M. C. S. Estatística experimental aplicada à experimentação agronômica. Piracicaba: ESALQ, Depto. de Matemática e Estatística, 1997. 250p. 
NOTT, J.; YOUNG, R.; BRYANT, E.; PRICE, D. Stratigraphy vs. Pedogenesis; problems of their correlation within coastal sedimentary facies. Catena, v. 23, n.2, p.199-212, Jan. 1994.

OLIVEIRA, J.B. Princípios básicos para classificação e sinopse. In: MONIZ, A.C. Elementos de pedologia. São Paulo, Ed. da Universidade de São Paulo, 1972. p. $351-362$.

OLIVEIRA, J.B. Solos da folha de Piracicaba. Campinas, Instituto Agronômico, 1999. 173 p. (Boletim científico, 48 )

OLIVEIRA, J.B.; PRADO, H. Carta pedológica semidetalhada do Estado de São Paulo; quadrícula de Piracicaba. Escala 1:100.000. Secretaria de Agricultura e Abastecimento do Estado de São Paulo, Coordenadoria de Pesquisa Agropecuária, Campinas: Instituto Agronômico, 1989.

OLIVEIRA, M. T.; SAMPAIO, A. C. F.; FUKS, S. D. Comparação entre os métodos de classificação fuzzy e booleano para determinação de mapas de umidade: Um estudo de caso. 1992. (mimeo.)

OLMOS ITURRI LARACH, J. Bases para Leitura de mapas de solos. Rio de Janeiro: Empresa Brasileira de Pesquisa Agropecuária/Serviço Nacional de Levantamento e Conservação de Solo. 1983. 91 p. (Série Miscelânea, 4).

OLMOS ITURRI LARACH, J. SOUZA, J.L.R.; SILVEIRA, C.O. Levantamentos pedológicos no Brasil executados pelo SNLCS - EMBRAPA. In: SIMPÓSIO BRASILEIRO DE SOLOS TROPICAIS EM ENGENHARIA, Rio de Janeiro, 1981. p.13-29.

OVALLES, F.A.; COLLINS, M.E. Soil-Landscape relationships and soil variability in North Central Florida. Soil Science Society of American Journal, v.50, n.2, p. 401408, March/April. 1986.

POST, D.F. Soil assessment - remote sensing application in Arizona. In: Proceedings of the applications of remote sensing to agriculture. Office of Arid Land Studies, University of Arizona, 1984. p. 45-56. 
POST, D. F.; HORVATH, E.H.; LUCAS, W.M.; WHITE, S.A.; EHASZ, M.J.; BATCHILY, A.K.; Relations between soil color and Landsat reflectance on semiarid rangelands. Soil Science Society of American Journal, v.58, p.1809-1816, 1994.

RAIJ, B. van; QUAGGIO, J.A.; CANTARELLA, H.; FERREIRA, M.E.; LOPES, A.S.; \& BATAGLIA, O.C. Análise química de solos para fins de fertilidade. Campinas, Fundação Cargill, 1987, 170p.

RAMALHO FILHO, A.; BEEK, K. J. Sistema de avaliação da aptidão agrícola das terras. 3 ed. Brasilia: SUPLAN; EMBRAPA,SNLCS, 1995. 65p.

RANIERI, S. B. L. Avaliação de métodos e escalas de trabalho para determinação de risco de erosão em bacia hidrográfica utilizando SIG. São Carlos, SP, 1996. 129p. Dissertação (Mestrado) - Escola de Engenharia de São Carlos, Universidade de São Paulo.

REUNIÃO TÉCNICA DE LEVANTAMENTO DE SOLOS, 10., 1979, Rio de Janeiro, RJ. Súmula... Rio de Janeiro; EMBRAPA-SNLCS, 1979. 83p. (EMBRAPASNLCS. Miscelânea, 1).

RIGNEY, J. A.; REED, J. F. Some factors affecting the accuracy of soil sampling. Soil Science Society of American Proceedings, v.10, p.57-259. 1945.

ROURKE, J. D. Orders of soil surveys, kinds of mapping units and their interpretations. NETSC, SCS/USDA, Broomal, Pensylvannia (mimeo). 1977.

SALDAÑA, A.; STEIN, A.; ZINCK, J.A. Spatial variability of soil properties at different scales within three terraces of the Henares River (Spain). Catena, v.33, p.139-153. 1998.

SALVIANO, A.A.C. Relações entre atributos de solo e produtividade de crotalária juncea em área erodida. Piracicaba, 1996. 92p. Tese (Doutorado) - Escola Superior de Agricultura "Luiz de Queiroz", Universidade de São Paulo. 
SANTOS, H. G. Dos. Some strategies of quality control for reconaissance soil survey. Ithaca, NY., 1978. Thesis (M.Sc.) - Faculty of the Graduate School of Cornell University,. 128p.

SAVIGEAR, R.A.G. A Technique of Morphological Mapping. Association of American Geographers, v. 53, n.3, p 514-588. 1965.

SCATOLINI, F.M.; MONIZ, A.C. Influência do material de origem, do lençol freático surgente e da posição topográfica nos solos de uma encosta em Mococa (SP). Revista Brasileira de Ciência do Solo, v.16, n.3, p. 379-388. set./dez. 1992.

SCHARGEL, R. Multipurpose applications of soil information. ITC Journal, 1993-1, p.23-29, 1993.

SOIL SCIENCE SOCIETY OF AMERICA. Statement on soil quality. Agronomy News, 6, 1995.

SPAROVEK, G. (coord.) Plano Diretor da Microbacia do Córrego do Ceveiro. Vol. I: Diagnóstico da situação, levantamento de problemas e propostas de solução. Piracicaba, Escola Superior de Agricultura "Luiz de Queiroz", 1991. 286 p. (Mimeo) SPAROVEK, G.; WEILL, M. de A. M; RANIERI, S. B. L.; SCHNUG, E.; SILVA, E. F. The time-life concept as a tool for erosion tolerance definiton. Scientia Agricola, v. 54, Número Especial, p.130-135. Junho. 1997.

SPAROVEK, R. B. M. Estimativa da erosão em sulcos e entre sulcos na Microbacia Hidrográfica do Córrego do Ceveiro - Piracicaba, SP. Piracicaba, 1998. 95p. Dissertação (Mestrado) - Escola Superior de Agricultura "Luiz de Queiroz", Universidade de São Paulo.

STOLT, M.H.; BAKER, J.C.; SIMPSON, T.W. Soil-landscape relationships in Virginia: I. Soil variability and parent uniformity. Soil Science Society of American Journal, v.57, n.2, p. 414-421, March/April. 1993.

THORP, I.; SMITH, S. Higher categories of soil classification: order, suborder, and great soil groups. Soil Science, v.67, p.117-126. 1949. 
UBERTI, A.A.; KLAMT, E. Relações solo-superficies geomórficas na encosta inferior do Nordeste do Rio Grande do Sul. Revista Brasileira de Ciência do Solo, v.8, n.2, p. 229-234, mai./ago. 1984.

VIDAL-TORRADO, P.; LEPSCH, I.F. Morfogênese dos solos de uma topossequência com transição B Latossólico/B Textural sobre migmatitos em Mococa (SP). Revista Brasileira de Ciência do Solo, v.17, n.1, p. 109-119, mai./ago. 1993.

VIEIRA, S.R Variabilidade espacial de argila, silte e atributos químicos em uma parcela expermental de um latossolo roxo de Campinas (SP). Bragantia, v.56, n.1, p.181$190,1997$.

VIEIRA, S.R; De MARIA, I.C. Delineamento experimental e análise estatística na pesquisa em conservação do solo. In: CASTRO FILHO, C.; MUZILLI, O. Ed. Manejo integrado de solos em microbacias hidrográficas. Londrina, IAPAR, 1996.

VIEIRA, S. R.; HATFIELD, J. L.; NIELSEN, D. R.; BIGGAR, J. W. Geostatistical theory and application to variability of some agroquemical properties. Hilgardia, Berkeley, 1983

VIEIRA, S. R.; NIELSEN, D. R.; BIGGAR, J. W. Spatial variability of field-measured infiltration rate. Soil Science Society of American Journal, v. 45, p.1040-1048, 1981.

VOLTZ, M; LAGACHERIE, P.; LOUCHART, X. Predicting soil properties over a region using sample information from a mapped reference area. European Journal of Soil Science, v.48, p.19-30, 1997.

WALKER, P. H.; HALL, G. R.; PROTZ, R. Relation between landform parameters and soil properties Soil Science Society of American Proceedings, v.32, n.1, p.101104,1968 .

WEBB, T.H.; BURGHAM, S.J. Catenary relationships of downland soils derived front loess, South Canterbury, New Zealand. Australian Journal of Soil Research, v.32, n.1, p. 1-11, 1994. 
WEBSTER, R. Soil Survey: its quality and effectiveness. Report for Soil Resource Inventory Workshop. Cornell University, Ithaca, NY. 1977.

WHITE, R.E. Soil science: raising the profile. Australian Journal of Soil Research, v.35, n.5, p.961-977, 1997.

WILDING, L.P.; DREES, L.R. Spatial variability and pedology. p.83-116. In. WILDING et al. (ed.). Pedogenesis and soil taxonomy. I. Concepts and interactions. Amsterdan: Elsevier. 1983. 375 p.

WILDING, L.P.; JONES, R.B.; SHAFER, G.M. Variation of soil morphological properties within Miami, Celina and Crosby mapping units in West-Central Ohio. Soil Science Society of American Proceedings, v.29, n.6, p.711-717, 1965.

WISCHMEIER, W.H. \& SMITH, D.D. Predicting rainfall erosion losses -A guide to conservation planning. U.S.: Department of Agriculture. Agricultural Handbook, 537. 1978.

ZINCK, J. A. Soil Survey: Epistemology of a vital discipline. International Institute for Aerospace Survey and Earth Sciences (ITC). Enschede, The Netherlands. $1990.40 \mathrm{p}$.

ZINCK, J.A. Introduction. In: J.A. ZINK (Ed). Soil Survey: Perspectives and Strategies for the $21^{\text {st }}$ Century. International workshop for heads of national soil survey organisations, 1992, Enschede. ITC Publication n.21, 1994. p.2-6. 